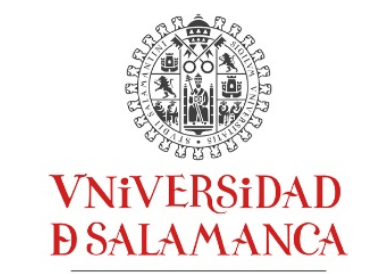

CAMPUS OF INTERNATIONAL EXCELLENCE

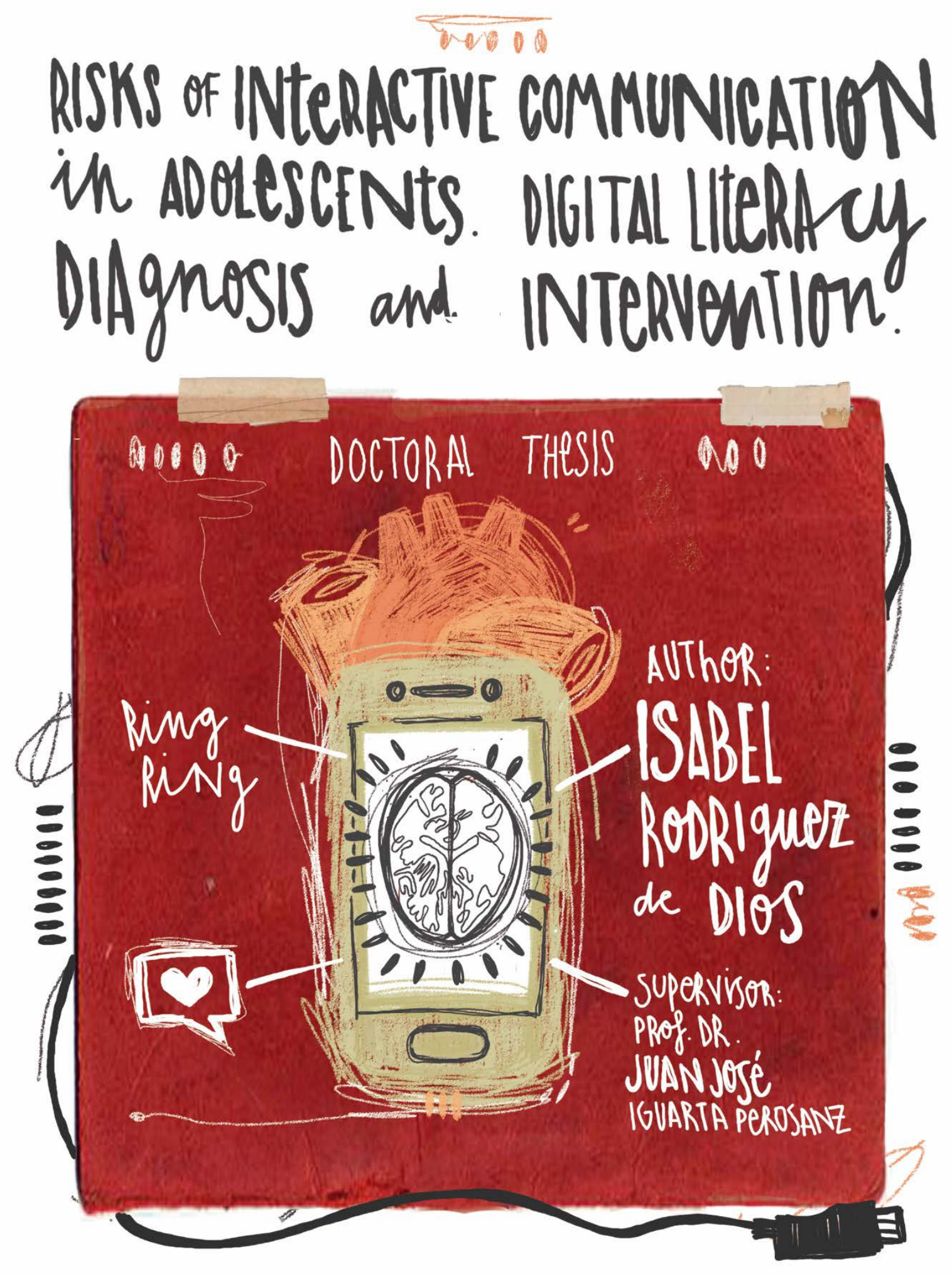





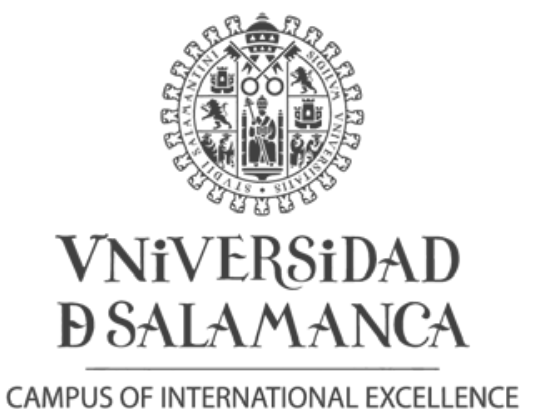

Doctorate in Training in the Knowledge Society

DOCTORAL THESIS

Risks of interactive communication in adolescents.

Digital literacy diagnosis and intervention

\author{
Doctoral Thesis Submitted by \\ Mrs. ISABEL RODRÍGUEZ DE DIOS \\ Thesis supervisor \\ prof. dr. JUAN JOSÉ IGARTUA PEROSANZ
}

Salamanca, 2018 



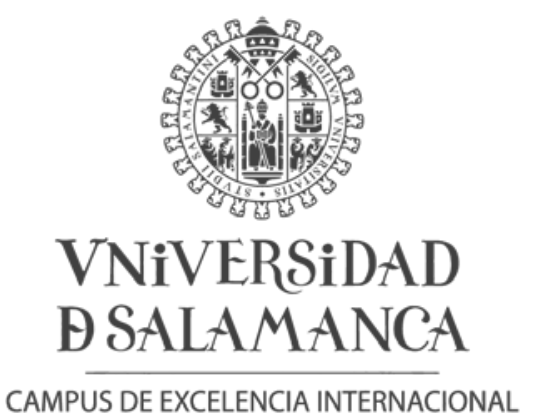

Programa de Doctorado Formación en la Sociedad del Conocimiento

TESIS DOCTORAL

Riesgos de la comunicación interactiva en la población adolescente. Diagnóstico e intervención de alfabetización digital

Trabajo de tesis presentado por:

Dña. ISABEL RODRÍGUEZ DE DIOS

Director

Prof. Dr. D. JUAN JOSÉ IGARTUA PEROSANZ

Salamanca, 2018 

This Doctoral Thesis was supported by a research grant to finance predoctoral recruitment of research personnel from the Government of Castile and Leon and the European Social Fund (EDU/1083/ 2013).

Esta tesis doctoral se ha podido llevar a cabo gracias a la concesión de una ayuda destinada a financiar la contratación predoctoral de personal investigador cofinanciada por la Junta de Castilla y León y el Fondo Social Europeo (EDU/1083/2013) 



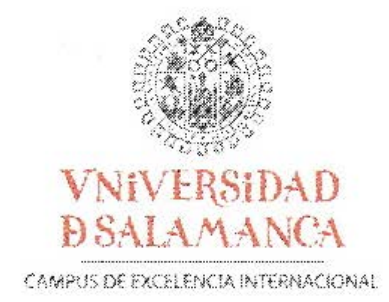

PROGRAMA DE DOCTORADO FORMACIÓN EN LA SOCIEDAD DEL CONOCIMIENTO (RD 99/2011)

Dr. Juan José Tgartua Perosanz, Catedrático de Universidad, del área de Comunicación Audiovisual y Publicidad de la Universidad de Salamanca, en calidad de Director del trabajo de tesis "Risks of interactive communication in adolescents. Digital literacy diagnosis and intervention" realizado por Dria. Isabel Rodríguez de Dios,

\section{HACE CONSTAR}

Que dicho trabajo tiene suficientes méritos teóricos contrastados adecuadamente mediante las validaciones oportunas, publicaciones relacionadas y aportaciones novedosas. Por Lodo ello manifiesta su acuerdo para que sea autorizada la presentación y defensa del Irabajo refericlo.

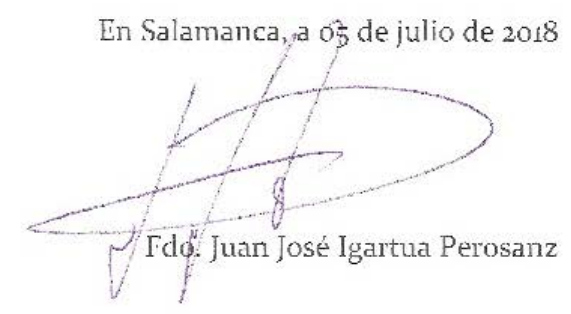





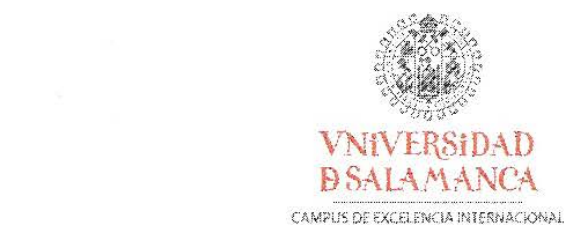

Programa de Doctorado Formación en la Sociedad del Conocimiento (RD 99/2011)

TESIS DOCTORAL

Risks of interactive communication in adolescents.

Digital literacy diagnosis and intervention

Director

Prof. Dr. JUAN JOSÉ TGARTUA PEROSAN7

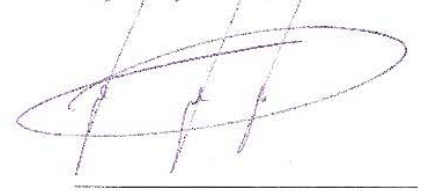

Doctoranda

Dña. ISABEL RODRÎGUEZ DE DIOS

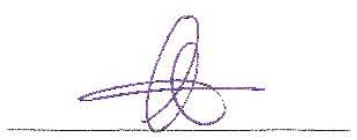

Salamanca, 2018 

To my parents

A mis padres 



\section{Acknowledgements}

nyone who has gone through the process of doing a $\mathrm{PhD}$ thesis knows that
it can be hard. Many people compare it to a roller coaster of feelings and
emotions, full of ups and downs. I prefer to compare it to a road, a long road beset with obstacles, stumbles and setbacks, but also with people who stand by your side, hold your hand and help you go down this road more easily. The following lines are for you, everyone who has accompanied me during the last year and has made this $\mathrm{PhD}$ thesis possible, in some way or another. THANKS to all of you.

My journey began many years ago, specifically, in 2011, when I did not really know much about a PhD thesis, and the Dr. Juan José Igartua encouraged me to do one under his supervision. Since then, his support, advice and knowledge have helped me on my road. Therefore, I would like to thank the supervisor of this $\mathrm{PhD}$ thesis. Thanks for your confidence in me, for your advice, for your high standards and for making this thesis what it is today.

I would also like to thank the University of Salamanca, especially the Faculty of Social Sciences and the Department of Sociology and Communication, where I conducted my work. My thanks also to the Doctorate in Training in the Knowledge Society, especially to its coordinator, Dr. Francisco José García Peñalvo, for his support in moving the thesis forward.

I have been accompanied on this road by a research group, the Observatorio de los Contenidos Audiovisuales (Observatory for Audiovisual Content, OCA). Many thanks to its members for their support and their invaluable contributions to the thesis. Special thanks for their support and company are due to the PhD students in the OCA, who have lived the daily life of my PhD. Firstly, thanks to my older brother, Valeriano Piñeiro, whom I admire and from whom I learned so much. Thank you for your knowledge and your invaluable advice. Secondly, thanks to my little siblings, the 
PhD students who joined the OCA later, but who have also accompanied, listened to and helped me. I would like to express my special thanks to Caty González, Alex González, Diego Cachón, Marta Cerezo, Iñigo Guerrero, Carla Portillo and Javier Amores. I am grateful also to all the researchers who stayed with the OCA and shed light on the thesis.

In a context in which obtaining funding for research is not easy, I must infinitely thank the Government of Castile and Leon and the European Social Fund for granting me a research fellowship to finance predoctoral recruitment of research personnel in 2014. When the road began to become narrower and stonier, this grant eased and paved my way.

Furthermore, this PhD contract also allowed me to teach on the Audiovisual Communication degree at the University of Salamanca. Therefore, I should thank Juanjo once again for the trust he placed in me when he let me teach on two of their courses, Processes and Media Effects, and Communication Research Methods. In this sense, my profound thanks to each and every PEM and MIC student for discovering my passion for teaching and for teaching me so much.

I cannot forget all of the students in secondary education who helped in providing the data for the study. To all of them, and to the fourteen education centres, their teachers and their management teams, my eternal gratitude for your indispensable collaboration.

Likewise, on this road it is necessary to highlight two key moments that gave me energy and enriched me, as a researcher and a person, which were my two research visits abroad.

First, I should thank all the members of the Center for Research on Children, Adolescents and the Media (CcaM) at the Amsterdam School of Communication Research (ASCoR) at the University of Amsterdam for their contributions and for making me feel at home (dank $u$ wel!). In particular, my thanks to my colleagues from 
the $\mathrm{PhD}$ room, to Dr. Ine Beyens (always willing to help) and to the Director of ASCoR, Dr. Jochen Peter, for their invaluable contributions. But above all, my eternal gratitude to Dr. Johanna M. F. (Annemarie) van Oosten, who supervised my research stay and contributed invaluable knowledge and expertise to this thesis. For your great kindness, for giving me the opportunity to be part of ASCoR and for your example as a researcher, thank you Annemarie.

Secondly, my great thanks go also to the Institute for Media Studies at KU Leuven and its members for allowing me to expand and improve my research. In particular, my special thanks to Dr. WIllem Joris, for his enthusiasm and his willingness to collaborate, and to Dr. Leen d'Haenens, who supervised my research stay and improved this doctoral thesis with her contributions and advice. Thank you very much Leen, once again, for giving me the opportunity to research and learn at KU Leuven.

On a more personal note, my sincerest and deepest gratitude to my family and friends, since they gave me strength and encouragement to keep moving forward. First, thanks to all my friends for all your support and for accepting that, during these years, I almost never had time for you. This road has been easier thanks to all of you.

Secondly, my eternal gratitude to my wonderful and dear family for always being there for me. In particular, my thanks to my parents for their example, for teaching me the value of work, effort and education, for believing in me and for their absolutely unconditional support. Thanks also to my mum, for her infinite patience, and to my dad, for teaching me the value of humility. I admire you and all this work has been possible thanks to you. My gratitude also to my siblings, who also suffered this thesis. Thanks to my twin brother, Valentín, for his help, for teaching me to stay humble and for making me laugh when the thesis took away my humour. To my sister María, for her help and understanding, and for bringing our nephew Nicolás into our 
lives, who has given us so much joy (I promise to return all the time this thesis stole from you).

Last but not least, my great thanks to my partner, Fran. It is not easy to accompany a person during this path full of worries, absences, cancelled plans and weekends dedicated to the thesis... In response to my nervousness, your eternal smile and your permanent calm have always remained so necessary for me. In addition, your support was not limited only to the personal level, you were present at all the stages of this path and the third study in this thesis would never have been possible without your development of the mobile application. I hope to have you by my side on all the roads still to be travelled. Thanks, and always thanks, Fran.

Now that I am near the end of the road, I look back with satisfaction at the work done and I feel extremely fortunate to have had all of you standing by my side. HUGE THANKS [a] 


\section{Agradecimientos}

C

ualquier persona que haya pasado por el proceso de una tesis doctoral sabe que es arduo y lleno de dificultades. Muchos lo comparan con una montaña

rusa de sentimientos y emociones, llena de subidas y bajadas. Yo prefiero compararlo con un camino, un camino muy largo y lleno de obstáculos, caídas y tropiezos, pero con muchas personas que están a tu lado, te dan la mano para ayudarte a recorrer este camino y lo hacen más fácil. Las siguientes líneas son para vosotros, todos los que me habéis acompañado en los últimos años y habéis colaborado, de una u otra forma, para que esta tesis saliera adelante. A todos, GRACIAS.

Mi camino comenzó hace ya muchos años. Concretamente en el año 2011, cuando yo aún no tenía muy claro que era eso de una tesis y el Dr. Juan José Igartua me propuso realizarla bajo su dirección. Desde entonces, su apoyo, sus consejos y todos sus conocimientos me han facilitado este camino. Por lo tanto, mi agradecimiento al director de esta tesis doctoral. Muchas gracias, Juanjo, por confiar en mí, por tu asesoramiento, por tu alto nivel de exigencia y por hacer posible que esta tesis sea lo que es hoy.

Mi agradecimiento también a la Universidad de Salamanca, en especial a la Facultad de Ciencias Sociales y al Departamento de Sociología y Comunicación, donde desarrollé mi trabajo durante todo este tiempo. También, mi agradecimiento al Programa de Doctorado en Formación en la Sociedad del Conocimiento, en especial a su coordinador, el Dr. Francisco José García Peñalvo, por toda la ayuda para que esta tesis saliera adelante.

Todo este camino lo he recorrido dentro de un grupo de investigación, el Observatorio de los Contenidos Audiovisuales (OCA). Mi agradecimiento a todos sus miembros por su apoyo y sus inestimables aportaciones a esta tesis. Debo agradecer especialmente la ayuda y compañía del resto de doctorandos del OCA, quienes han 
vivido el día a día de este camino. En primer lugar, a mi hermano mayor, Valeriano Piñeiro, a quien admiro y de quien tanto he aprendido. Gracias por tus conocimientos e invaluables consejos. Y, en segundo lugar, a mis hermanos pequeños, los doctorandos que se fueron incorporando posteriormente, pero que también me han acompañado, escuchado y ayudado. Mi especial agradecimiento para Caty González, Alex González, Diego Cachón, Marta Cerezo, Iñigo Guerrero, Carla Portillo y Javier Amores. Mi agradecimiento también para todos aquellos investigadores que decidieron hacer una estancia en el OCA y aportaron luz a esta tesis.

En un contexto en el que obtener financiación para investigar no es nada fácil, debo agradecer infinitamente a la Junta de Castilla y León y al Fondo Social Europeo la concesión de una ayuda destinada a financiar la contratación predoctoral de personal investigador en 2014. Cuando el camino empezaba a hacerse más angosto y pedregoso, la obtención de este contrato permitió allanar y facilitar mi camino.

Este contrato predoctoral me dio también la oportunidad de participar en la docencia del grado de Comunicación Audiovisual de la Universidad de Salamanca. Por ello, debo agradecer de nuevo a Juanjo su confianza en mí, al permitirme impartir docencia en dos de sus asignaturas: Procesos y Efectos Mediáticos, y Métodos de Investigación en Comunicación. En este sentido, mi profundo agradecimiento a todos y cada uno de los alumnos de PEM Y de MIC por descubrir mi pasión por la docencia y por enseñarme tanto.

No puedo olvidar tampoco a todos los alumnos de educación secundaria que prestaron su ayuda aportando los datos que sustentan esta investigación. A todos ellos y, por supuesto, a los catorce centros educativos, sus equipos directivos y docentes, mi eterno agradecimiento por vuestra colaboración imprescindible para esta tesis.

Asimismo, en este camino es necesario destacar dos momentos que me aportaron mucha energía y me enriquecieron enormemente, como investigadora y como persona: la realización de dos estancias de investigación en el extranjero. 
En primer lugar, debo agradecer a todos los miembros del Center for Research on Children, Adolescents, and the Media (CcaM), de la Amsterdam School of Communication Research (ASCoR) de la Universidad de Amsterdam, sus aportaciones y que me hiciesen sentir como en casa (dank $u$ wel!). En especial, mi agradecimiento para las chicas de la $\mathrm{PhD}$ room, para la Dra. Ine Beyens (siempre dispuesta a ayudar) y para el director de ASCoR, el Dr. Jochen Peter, por su inestimable colaboración. Pero, sobre todo, mi eterno agradecimiento a la Dra. Johanna M. F. (Annemarie) van Oosten, quien supervisó mi estancia y aportó invaluables conocimientos y experiencias a esta tesis. Por tu gran amabilidad, por darme la oportunidad de formar parte de ASCoR y por tu ejemplo como investigadora, muchas gracias Annemarie.

En segundo lugar, mi gran agradecimiento al Institute for Media Studies de KU Leuven y a sus integrantes por permitirme ampliar y mejorar mi investigación. En especial, mi gran agradecimiento al Dr. Willem Joris, por su predisposición a colaborar y su entusiasmo, y a la Dra. Leen d'Haenens, quien supervisó mi estancia y mejoró esta tesis doctoral con sus aportaciones y consejos. Muchas gracias Leen, una vez más, por darme la oportunidad de investigar y aprender en KU Leuven.

En un plano más personal, mi agradecimiento más sentido y profundo a mi familia y amigos, ya que me dieron fuerza y ánimos para seguir siempre hacia adelante. En primer lugar, gracias a todos mis amigos y amigas por todo vuestro apoyo y por aceptar que durante estos años casi nunca tuviera tiempo para vosotros. Este camino ha sido más sencillo gracias a todos vosotros.

En segundo lugar, mi eterno agradecimiento a mi maravillosa y querida familia por estar siempre ahí. En especial, mi agradecimiento a mis padres por su ejemplo, por enseñarme el valor del trabajo, del esfuerzo y de la educación, por creer en mí y por su apoyo absolutamente incondicional. A mi madre, por su infinita paciencia, y a mi padre, por transmitirme el valor de la humildad. Os admiro y todo este trabajo ha sido posible gracias a vosotros. Mi agradecimiento también a mis 
hermanos, quienes tuvieron que soportar esta tesis. A mi hermano mellizo, Valentín, por su ayuda, por enseñarme a mantener los pies en la tierra y por hacerme reír cuando la tesis se llevaba mi buen humor. A mi hermana María, por su ayuda y comprensión, y por traer a nuestras vidas a mi sobrino Nicolás, quien tanta alegría nos ha regalado (prometo devolverte todo el tiempo que esta tesis te robó).

Por último, pero, por supuesto, no menos importante. Mi enorme agradecimiento para mi pareja, Fran. No es fácil acompañar a una persona durante este camino lleno de preocupaciones, ausencias, planes cancelados y fines de semana dedicados a la tesis... Frente a mi nerviosismo, siempre ha estallado tu eterna sonrisa y tu permanente calma, tan necesaria para mí. Además, tu apoyo no se limitó al ámbito personal, estuviste presente en todas las etapas de este camino, y el tercer estudio de esta tesis nunca hubiera sido posible sin tu desarrollo de la aplicación móvil. Espero contar con tu compañía en todos los caminos que me quedan por recorrer. Gracias, y siempre gracias, Fran.

Hoy, que ya veo el fin del camino muy cerca y miro hacia atrás con satisfacción por el trabajo realizado, me siento enormemente afortunada de haber contado con todos vosotros. MUCHAS GRACIAS 


\section{Index}

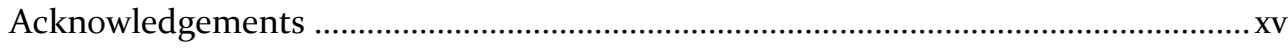

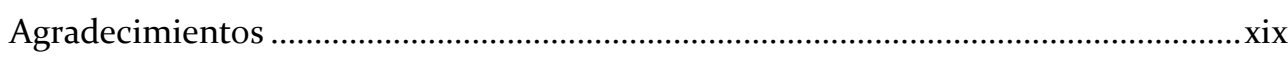

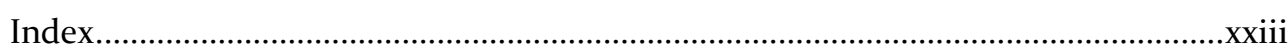

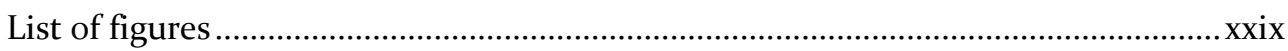

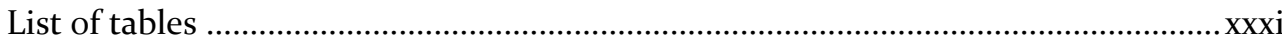

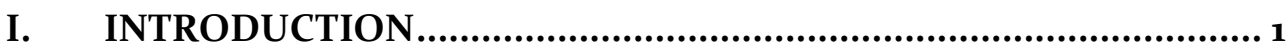

II. THEORETICAL BACKGROUND...........................................1

CHAPTER 1. ADOLESCENTS AND INTERACTIVE COMMUNICATION ....................13

1.1. Information and Communication Technology and Interactive Communication

14

1.1.1. Integration and use of information and communication technology ....... 19

1.2. Adolescents and their Use of Interactive Communication..............................23

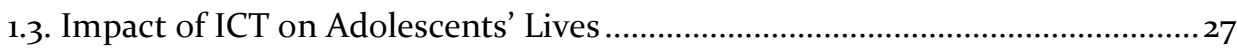

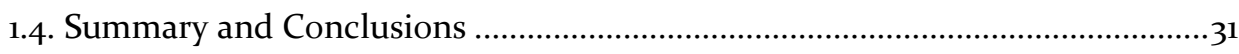

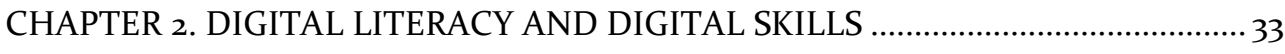

2.1. What is Digital Literacy? Antecedents and Definition ..................................34

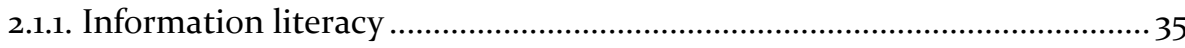

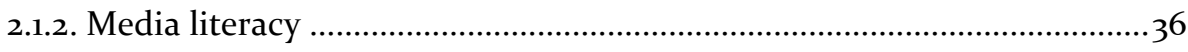

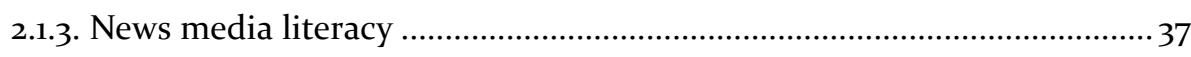

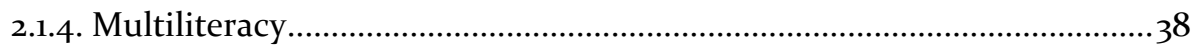

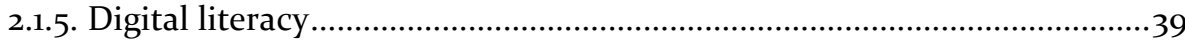

2.2. Digital Literacy as a Set of Digital Skills .....................................................42

2.3. Digital Literacy Measures ................................................................................49

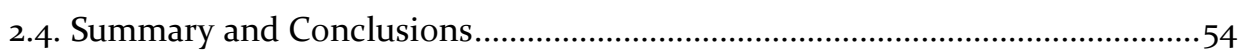

$$
\sim \text { xxiii }
$$


CHAPTER 3. ONLINE RISKS AND ONLINE OPPORTUNITIES...................................55

3.1. Online Risk Behaviours and their Consequences .............................................. 56

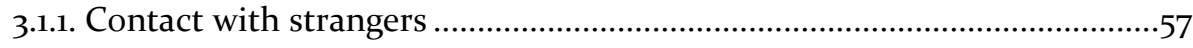

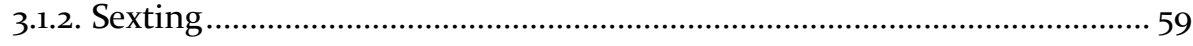

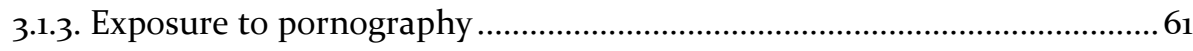

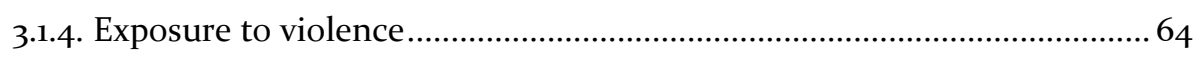

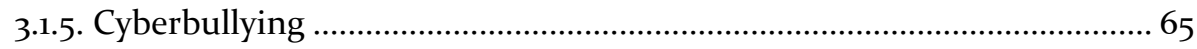

3.2. Opportunities and Benefits of Interactive Communication............................. $7 \mathrm{o}$

3.3. The Role of Digital Skills in Online Risks and Online Opportunities .............. 74

3.4. Summary and Conclusions ................................................................................... 76

CHAPTER 4. PROMOTING DIGITAL SAFETY ……………………………………..... 79

4.1. Technological Mediation: Use of Filtering and Control Software...................... 79

4.2. Parental Mediation of Adolescents' Digital Media Use ..................................... 82

4.2.1. Impact of parental mediation on adolescents' online risks and

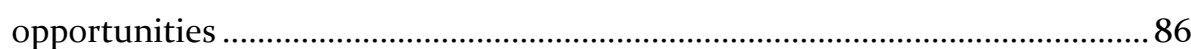

4.2.2. The role of digital skills in parental mediation of online risks and

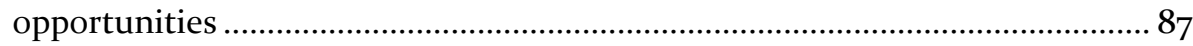

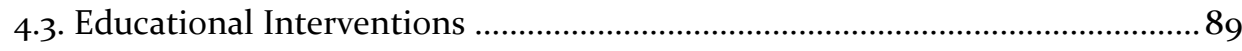

4.3.1. Interventions promoting digital safety …………....................................... 89

4.3.2. Coping strategies for facing online risks...................................................101

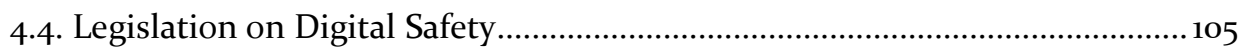

4.5. Summary and Conclusions ...............................................................................108

CHAPTER 5. MOBILE LEARNING AND NARRATIVE PERSUASION ...........................11

5.1. Mobile learning and its theoretical bases ............................................................112

5.1.1. Constructivist theory ......................................................................................114

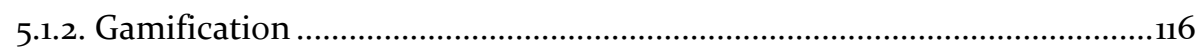

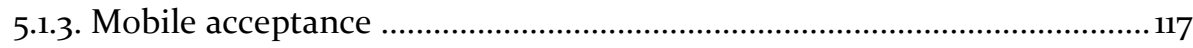

5.2. Is Mobile Learning Effective? A Review of Previous App Interventions ..........118 $\sim$ xxiv 
5.3. The Entertainment-Education Strategy ………………………………………....127

5.4. The Power of Narrative and its Explanatory Mechanisms................................132

5.5. Narrative Persuasion in Mobile Learning ..........................................................138

5.6. Summary and Conclusions.......................................................................... 140

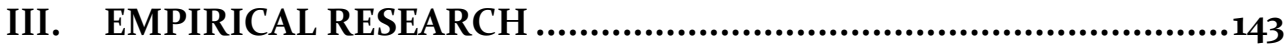

CHAPTER 6. STUDY 1. DEVELOPMENT AND VALIDATION OF THE DIGITAL

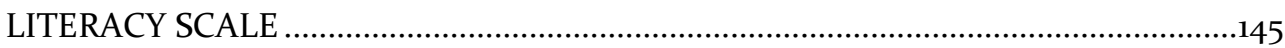

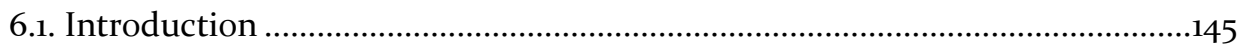

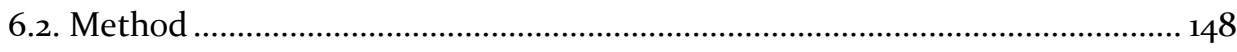

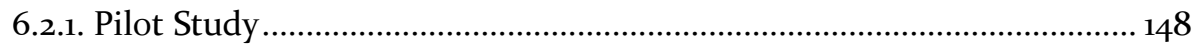

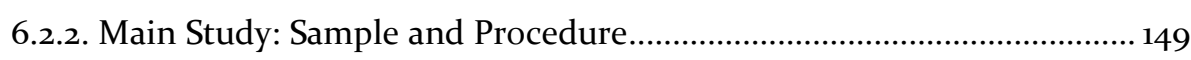

6.2.3. Measures ……………………………………………………………...150

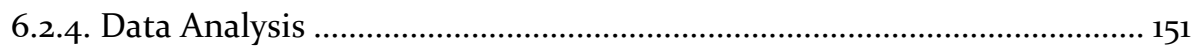

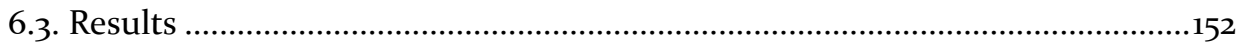

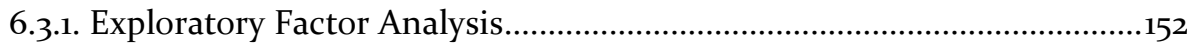

6.3.2. Confirmatory Factor Analysis.....................................................................158

6.3.3. Convergent Validity of the Digital Literacy Scale.....................................159

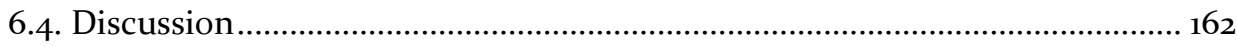

CHAPTER 7. STUDY 2. RELATIONSHIP BETWEEN PARENTAL MEDIATION AND ADOLESCENTS' DIGITAL SKILLS, ONLINE RISKS AND ONLINE OPPORTUNITIES

7.1. Introduction

$$
\sim \mathrm{xxv} \sim
$$


7.3.1. Testing the Hypothesised Model.................................................................. 175

7.4. Discussion .......................................................................................................... 177

CHAPTER 8. STUDY 3. DIGITAL LITERACY INTERVENTION AND COPING

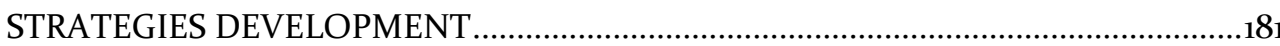

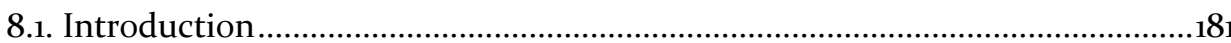

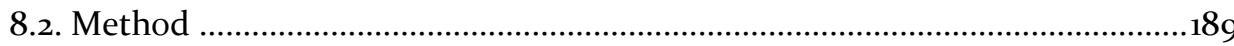

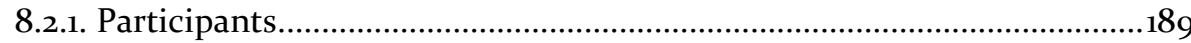

8.2.2. Design and Procedure …………………………………………….......190

8.2.3. Materials: Development of the Mobile Application (CompDig) and Pilot

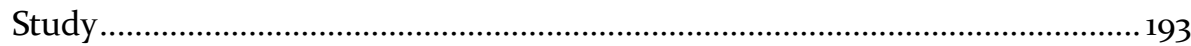

8.2.4. Measures ………………………………………….................................199

8.2.5. Data Analysis .............................................................................................. 201

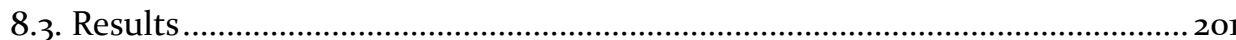

8.3.1. Preliminary Data Analysis: Equivalence of the Experimental Groups ... 201

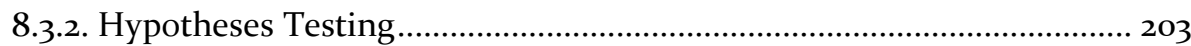

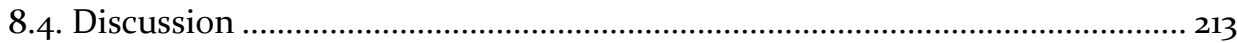

CHAPTER 9. DISCUSSION AND GENERAL CONCLUSIONS...................................219

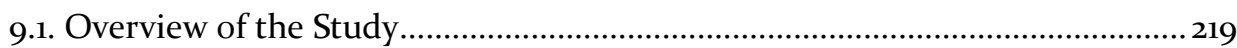

9.2. Implications for Theory and Research .........................................................227

9.3. Critical Reflections and Limitations .................................................................. 230

9.4. Suggestions for Further Studies ......................................................................232

9.5. General Conclusions....................................................................................... 234

9.6. Conclusiones Generales ................................................................................235

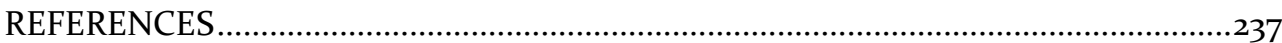

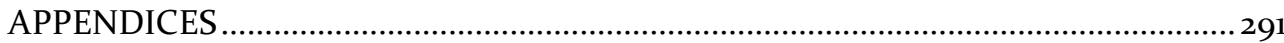

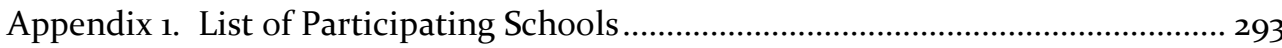

Appendix 2. Information Email for School Board ........................................................ 297 
Appendix 3. Consent Form for Parents....................................................................305

Appendix 4. Survey: Questionnaire ……………………………………………….....309

Appendix 5. Contents of the App .............................................................................. 321

Appendix 6. Experiment: Pre-test Questionnaire ………………………………....... 335

Appendix 7. Experiment: Post-test Questionnaire......................................................341

Appendix 8. List of Variables in English....................................................................351

Appendix 9. Media Coverage of the Thesis .....................................................................363 



\section{List of figures}

Figure 1. Evolution of Internet user across the world 2005-2017 …...........................20

Figure 2. Evolution of active social media use across the world 2010-2018.................21

Figure 3. Evolution of daily Internet user in Spain 2005-2017 ....................................22

Figure 4. Proportion of Internet users, by age. ......................................................... 23

Figure 5. Internet penetration rate among Spanish children aged 4-13 years ............25

Figure 6. Proportion of Spanish adolescents (aged 12-15) using ITC ...........................26

Figure 7. Technological equipment in Spanish households......................................27

Figure 8. Percentage of European and Spanish minors that spend half or more of waking time at home in their own room, by age..................................................29

Figure 9. Prevalence of online risk behaviours among European adolescents............68

Figure 10. Confirmatory factor analysis solution for the Digital Literacy Scale ........ 16o

Figure 11. Second-order factor structure of the Digital Literacy Scale........................ 161

Figure 12. Relationship between parental mediation, digital literacy and online risks and online opportunities ............................................................................

Figure 13. Structural Equation Model with standardised estimates ..........................176

Figure 14. Frequency of online contact risks on adolescents.....................................183

Figure 15. Student using the app during the intervention ........................................193

Figure 16. Snapshot of the character selection and the menu screens .......................195

Figure 17. Scenes of the videos from the mobile application..................................... 196

Figure 18. Snapshot of the achievements completed screen .................................... 197

Figure 19. Differences between the control and the experimental group on pre-test and

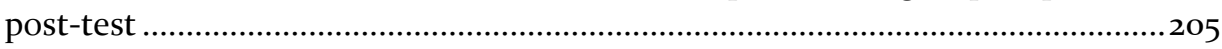

Figure 20. Johnson-Neyman regions of significance for the conditional effect of the use of the mobile application on the intention to use communicative coping strategies at levels of age..... 209

Figure 21. Identification with the protagonist and narrative transportation considering

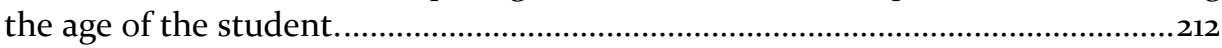

Figure 22. Theoretical model developed in the second study .................................228

$$
\sim \text { xxix } \sim
$$




$$
\sim \mathrm{xxx} \sim
$$




\section{List of tables}

Table 1. Categories of information and communication technology products and services.

Table 2. Classification of interactive communication forms and their functions ...... 18

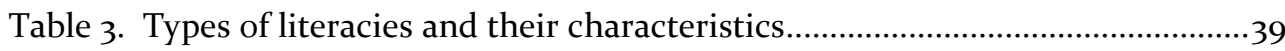

Table 4. Conceptual model of digital literacy from Eshet-Alkalai (2004)...................43

Table 5. Conceptual model of digital literacy of Area and Pessoa (2012) ....................44

Table 6. Conceptual model of digital literacy of Monereo (2005) ................................45

Table 7. Conceptual model of digital literacy of Cabero Almenara et al. (2012) ........45

Table 8. Conceptual model of digital literacy for the present study ...........................49

Table 9. Digital literacy measures developed and validated among adolescents ......52

Table 10. Online risk behaviours and their possible negative outcomes ................... 69

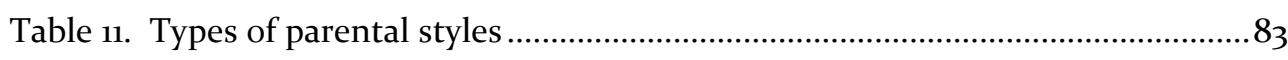

Table 12. Impact of parental mediation on digital skills and online risks and

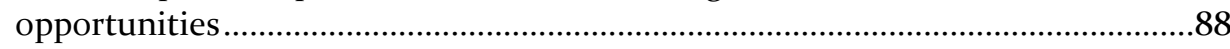

Table 13. Educational interventions against online risks ............................................92

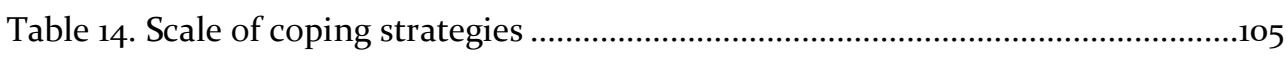

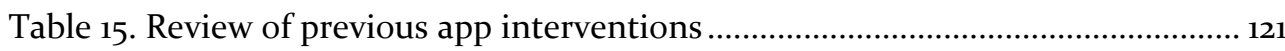

Table 16. Items excluded because of extreme values of skewness and kurtosis ........ 149

Table 17. Exploratory Factor Analysis matrix loadings...............................................154

Table 18. Exploratory factor analysis for the Digital Literacy Scale ...........................155

Table 19. Standardised regression weights ...............................................................159

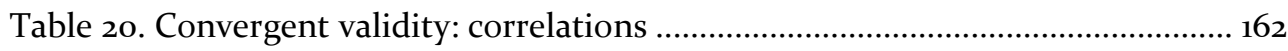

Table 21. Digital skills on the Digital Literacy Scale ...................................................163

Table 22. Homogeneity of the groups: experimental and control. ..............................201

Table 23. Distribution of demographic characteristics .............................................202

Table 24. Impact of the mobile application on the level of personal security skill and on the intention to use coping strategies. ..204 
Table 25. Multiple linear regression analyses for personal security skill and active coping strategies.

207 


\section{INTRODUCTION}



$\mathrm{O}$ ver the last few years, adolescents have increased their use of information and communication technology. Every day minors spend more and more time using technologies such as the Internet, computers, tablets or smartphones. In fact, the percentage of Spanish adolescents that use the Internet is close to 100 per cent. Almost all the young people in Spain use the Internet and computers, and have a mobile phone (INE, 2017).

In this context, interactive communication has gained visibility and relevance. According to Scolari (2008), interactive communication is a type of communication mediated by digital technologies. Most adolescents use some form of interactive communication daily. In fact, it has become a social norm among adolescents (Favotto, Michaelson, \& Davison, 2017). Accordingly, more than nine in ten Spaniards aged 12-17 use instant messaging services and have a social media profile (Golpe Ferreiro, Gómez Salgado, Kim Harris, Braña, \& Rial, 2017).

Consequently, in the last decades there has been a significant increase in research focusing on minors and information and communication technology. Thus, many studies analyse the frequency, location of access or purposes of the use of this technology in children and adolescents (e.g., Beentjes, Koolstra, Mareille, \& van der Voort, 20o1; Garitaonandia, Fernández, \& Oleaga, 2005; Ólafsson, Livingstone, \& Haddon, 2013). However, parents and educators, and therefore researchers, are particularly concerned about the effects, especially negative, that this use may have in minors. For this reason, research is also being carried out on online risks. These studies mainly analyse the type of risks that coexist (e.g., Catalina García, López de Ayala López, \& García Jiménez, 2014; Lin, 2009), their frequency of occurrence (e.g., Livingstone, Haddon, \& Görzig, 2011), and their consequences (e.g., Chalfen, 2009; Garaigordobil, 2011; Hinduja \& Patchin, 2010). Some of this research raises awareness among parents, educators and policymakers of the importance of taking urgent measures, such as parental mediation and educational interventions, to address these risks. 
Therefore, there is growing concern about the use of technology by adolescents because of the risks they could face. We cannot ignore the opportunities of this use for young people and their interests, such as the positive effect of interactive communication in some circumstances (Valkenburg \& Peter, 2009). However, these technologies also have risks that we need to identify and be careful of (Ktoridou, Eteokleous, \& Zahariadou, 2012). These risks are of concern in the case of minors because of their extensive use of digital technology and because they form a part of the population that requires special protection. Moreover, although they are "very sophisticated users of technology and often lead the way in adapting new technologies to everyday use, their technological savvy, combined with the ability to be online without much adult supervision, can lead to behaviours that are high risk" (Agatston, Kowalski, \& Limber, 2007, p. 59).

In this regard, when scholars talk about online risks they usually refer to contact with strangers, engagement in sexting, exposure to pornography, exposure to violence and cyberbullying (Agatston et al., 2007; Catalina García et al., 2014; Dowdell, Burgess, \& Cavanaugh, 2009; Livingstone \& Helsper, 2010; Livingstone \& Smith, 2014; Staksrud, Ólafsson, \& Livingstone, 2013; Vandoninck, d'Haenens, \& Roe, 2013). Against this background, minors should be "encouraged to assume responsibility for their own safety as much as possible with a focus on empowerment, emphasizing responsible behaviour and digital citizenship" (Livingstone, Haddon, Görzig, \& Ólafsson, 2011a, p. 10). Along these lines, there is a line of research that suggests that we must focus on the training of minors, specifically on their digital skills training, as a prevention tool (Chisholm, 2006; Eshet-Alkalai, 2004; S.-J. Lee \& Chae, 2012; O’Neill, Livingstone, \& McLaughlin, 2011; Rodríguez-de-Dios \& Igartua, 2014; Sonck, Livingstone, Kuiper, \& de Haan, 2011). Thus, through this training, young people could become digitally literate and more competent and confident in the digital environment. 
Despite the fact that new generations are digital natives and are at the forefront of new technologies, they have difficulty in managing information, assessing the credibility of information, building their digital identity, and managing their privacy online (González, 2012). Therefore, we presuppose that, despite being digital natives, they are not digital literates, as the frequent use of digital devices does not imply digital literacy. Consequently, it is the same with media literacy; the mass consumption and indiscriminate use of media is not associated with knowledge of the codes of visual language. That is why users are still defenceless against media messages (Moreno, 2008). Furthermore, when it comes to defending digital literacy as a prevention tool against the risks of interactive communication, we take into consideration the good results obtained by media literacy. In this way, media literacy interventions have proved to be effective in addressing the harmful effects of mass media (Jeong, Cho, \& Hwang, 2012).

In this regard, it is important to stress that we cannot deprive adolescents of interactive communication, and information and communication technology. In addition, it would be an impossible task. However, as we have mentioned, the solution is to give them the tools to be able to use these technologies safely. These tools appear with the development of digital skills. That is, through a process of digital literacy, children could manage these risks and maximise the opportunities offered by interactive communication. Consequently, the overall goal of this doctoral thesis is to improve digital skills in adolescents with the aim that they can afford, without danger, the risks of interactive communication and can maximise the opportunities that this communication gives to them. From this overall goal, we set the following specific objectives:

- Create a methodological tool, which will be submitted to statistical tests for reliability and validity to assess the level of digital skills of a population.

- Analyse which personal and parental factors influence the level of digital skills, online risk behaviours and online opportunities. 
- Determine whether there is a relationship between digital skills and online risk behaviours.

- Develop an intervention, using a mobile application, based on entertainmenteducation strategy and theories of narrative persuasion, to enable digital literacy.

Therefore, this study aims to increase the digital skills of adolescents through two processes: a first process of performing a diagnosis of digital skills, and a second process of intervention for digital literacy. With this purpose, three studies are conducted. First, and with the aim of developing and validating a scale to assess the level of digital literacy in teenagers, a survey is conducted. Scales are used to assess complex constructs that cannot be defined easily with one quiz question in a questionnaire (Igartua, 2006), and digital literacy is such a complex construct. Therefore, and considering previous literature, the scale is developed and submitted to statistical tests of reliability and validity (exploratory and confirmatory factor analyses, and correlation with other variables).

The second study is related to this digital literacy diagnosis and is also conducted by the survey technique. Because the goal of this thesis is to provide adolescents with digital skills, it is necessary to know their level of skills beforehand. Furthermore, we aim to analyse which parental factors influence the level of digital literacy, online risk behaviours and online opportunities, and to determine whether there is a relationship between digital literacy and online risk behaviours. Accordingly, a structural equation model is constructed to answer these questions.

The third study consists of a digital literacy and coping strategies intervention based on mobile learning. Instead of using a traditional educational intervention, we develop a mobile application with the educational content. For developing this app, we consider mobile learning theories, the strategy of entertainment-education and 
narrative persuasion theory. Finally, with the aim of checking its effectiveness, the app is evaluated by a quasi-experimental design with two groups.

This doctoral thesis is structured in three main parts, followed by two sections (references and appendixes). The first part (present part) gives a short introduction to the doctoral thesis. The second part, formed by five chapters (from chapter 1 to chapter 5), provides the theoretical background of the research. The third part includes the empirical research and is composed by three chapters, one for each study (from chapter 6 to chapter 8). Finally, chapter 9 provides discussion and general conclusions of the thesis. Bellow, there is a chapter overview.

Chapter 1 presents the starting point of the study and, consequently, some relevant terms for the study, such as interactive communication, are defined. We also present some statistical data on the integration of information and communication technology in society and its effects. After this, we focus on adolescents and review how and how often they use technology. Finally, we examine the impact that this use has on adolescents' lives.

Since digital technology is present in all areas of our lives (education, communication, entertainment, etc.), this makes digital skills essential to function effectively in this environment. Consequently, chapter 2 presents a review of digital literacy and digital skills. We review the concept of digital literacy and other literacies with which digital literacy shares conceptual ground. Moreover, we analyse the digital skills that are included in the broader concept of digital literacy and the digital literacy measures that have been developed.

Chapter 3 provides a review of adolescents' online risks and online opportunities, two closely related topics in their use of digital media. First, we analyse the different types of online risk behaviours (contact with strangers, sexting, exposure to pornography, exposure to violence and cyberbullying), their frequencies and their consequences for adolescents. Secondly, we refer to online opportunities, which 
RISKS OF INTERACTIVE COMMUNICATION IN ADOLESCENTS.

DIGITAL LITERACY DIAGNOSIS AND INTERVENTION

adolescents can take advantage of via digital media. Finally, we discuss the role of digital literacy and digital skills as a prevention tool against online risks and as a facilitator of online opportunities.

Given these concerns about online risks and online opportunities, in chapter 4 we examine the different strategies that have been promoted by the different stakeholders involved (parents, educators, policymakers and researchers) with the aim of safeguarding adolescents' digitally and empowering them: technological mediation, parental mediation and educational interventions. We review their characteristics and the research conducted to evaluate their effectiveness. This helps us obtain more insight into the strategies that have been used, and into why educational strategies are preferred and evaluated as more effective and helpful. In this chapter we also briefly review the legislation adopted by policymakers with digital safety in mind.

Since educational initiatives have proved to be an effective tool for promoting adolescents' digital safety, in chapter 5 we look at theoretical approaches and strategies that have been found to be successful for knowledge dissemination: mobile learning, entertainment-education and narrative persuasion. We examine the theoretical bases that support the use of mobile learning (constructivism and gamification) and review research on the effectiveness of mobile learning initiatives developed through mobile applications. We also discuss the effectiveness of the entertainment-education strategy, the possibilities and effects of narratives and their explanatory mechanisms (narrative transportation and identification with characters). To conclude the chapter and the theoretical framework, we analyse the possibility of combining the use of narrative persuasion and mobile learning.

Chapter 6 presents the first study of the thesis. Using a quantitative methodology, we develop and validate a scale to assess the level of digital literacy in adolescents. Exploratory factor analysis and confirmatory factor analysis reveal the 
existence of six digital skills (technological skill, personal security skill, critical skill, device security skill, informational skill and communication skill) measured through 28 items. Results and implications are discussed.

In chapter 7 we present the second study. Using data from a cross-sectional survey among 1,446 Spanish adolescents in secondary education, we aim to achieve two goals. First, we aim to examine how adolescents' digital skills are related to their online opportunities and online risk behaviours. Second, we aim to study whether adolescents' digital skills mediate the relationship between parental mediation and adolescents' online risks and opportunities. This chapter increases our knowledge on adolescents' digital literacy and the role of parental mediation (active and restrictive). Results and implications are discussed.

Chapter 8 is based on the third, and last, study of the thesis. Taking the results of the previous study as a starting point, we conduct a quasi-experiment for evaluating the impact of a mobile application on adolescents. This mobile application is developed, considering the theories of constructivism, gamification, mobile learning and narrative persuasion, with the aim of teaching digital skills and coping strategies for facing online risks to young people. Results and implications are discussed.

Finally, in chapter 9 we present an overview of the study and the general conclusions derived from it. Additionally, we examine the theoretical implications of the present thesis, identify its main limitations and suggest future research in this field. As a complement, seven appendices that provide supplementary information about the thesis have been incorporated. 



\section{THEORETICAL}

BACKGROUND 



\title{
Chapter 1.
}

\section{ADOLESCENTS AND \\ INTERACTIVE}

\section{COMMUNICATION}

\begin{abstract}
$\mathrm{O}$ ver the last decades there has been a spread of information and communication technologies, such as the Internet, computers, smartphones and tablets. These technologies have made an impact on many aspects of our lives: leisure, education, work and personal communications, among others (Area Moreira \& Pessoa, 2012). Consequently, in this chapter we will discuss the emergence of information and communication technology, interactive communication, and their impact on the knowledge society. We will also define and clarify those terms, as they will be relevant for the present study. Subsequently, we will focus on adolescents and we will analyse how they use these technologies, how often they do it and for what purposes. We will conclude the chapter with an examination of the impact that the use of information and communication technology and interactive communication currently has on adolescents' lives.
\end{abstract}




\subsection{Information and Communication Technology and Interactive Communication}

Information and communication technologies (ICT), along with fast Internet connections, have become accessible for most of the world's population and, as such, increasingly important in our lives. Nowadays, digital technologies, such as computers and smartphones, are present in all areas of our lives. We use them to communicate, study, work, learn and entertain ourselves. As a point of interest, these technologies are so relevant nowadays that the World Bank Institute has included the information and communication infrastructure ${ }^{1}$ of a country as one of the four pillars of its knowledge economy (Romani, 2009).

The incorporation of this technology into everyday life, together with other factors, has given rise to what is known as the knowledge society. The concept of knowledge society "primarily referred to economic systems where ideas or knowledge functioned as commodities" (Anderson, 2008, p. 6). Thus, in this society, "knowledge has become the central economic resource and source of additional economic growth" (Stehr, 2015, p. 105). Consequently, organisations operate in a knowledge-based economy characterised by intense competition, flexible production, service delivery systems and decentralised decision making (van Laar, van Deursen, van Dijk, \& de Haan, 2017). Therefore, information and communication technology has contributed to the emergence of this society by facilitating communication, by breaking down distance between groups and individuals, and by making accessing and sharing knowledge more feasible (Anderson, 2008; Stehr, 2015).

In this sense, it must be noted that, although sometimes they are used interchangeably, the concept of knowledge of society and the concept of knowledge information are not exactly the same (Anderson, 2008). The concept of knowledge

${ }^{1}$ Measured as number of digital devices (telephones, computers and Internet users) per 1,ooo people. 
society encompasses social, ethical and political dimensions. Thus, it is "more allembracing and more conducive to empowerment", since the concept of information society is only based on technological breakthroughs, which are crucial but should not be viewed as an end (Bindé \& Matsuura, 2005, p. 27).

Additionally, the emergence of the knowledge society has made it essential for citizens to acquire digital skills (ETS, 2002; Ilomäki, Paavola, Lakkala, \& Kantosalo, 2016). They need it for facing new challenges, such as the changing requirements of jobs and the great amount of available information (van Laar et al., 2017), and for using ICT effectively. Therefore, digital skills and digital literacy will be discussed in greater detail later.

Furthermore, it is important to clarify the meaning of information and communication technology before proceeding. This concept refers to technological devices (hardware and software) that enable communication and both interpersonal and multidirectional collaboration, and that are used for gathering, manipulating, storing, exchanging and transmitting data between different information systems (Mesa Agudelo, 2012; Romani, 2009). Consequently, it is a technology that supports the use of information and the activity of communication. Some of its most important characteristics are its interactivity, its asynchronism and that it allows the elimination of temporary space barriers (Mesa Agudelo, 2012).

Moreover, ICT covers "electronic and digital devices such as computers, the Internet, and other multimedia technology" (Zakaria \& Khalid, 2016, p. 1038). Other researchers add mobile phones, websites and social networks to the list of ICT tools (Massimini \& Peterson, 2009). Furthermore, the OECD, which defines ICT as products primarily intended to "fulfil or enable the function of information processing and communication by electronic means, including transmission and display" (OECD, 2011, p. 31), has made a classification of ICT products and services (see Table 1). In this 
RISKS OF INTERACTIVE COMMUNICATION IN ADOLESCENTS.

DIGITAL LITERACY DIAGNOSIS AND INTERVENTION

classification, they included elements such as laptops, videogame consoles, digital cameras, mobile phones and the Internet.

Table 1.

Categories of information and communication technology products and services

\begin{tabular}{|c|c|}
\hline Broad category & Examples of ICT products and services \\
\hline $\begin{array}{l}\text { Computers and } \\
\text { peripheral equipment }\end{array}$ & $\begin{array}{l}\text { Laptops, notebook computers, keyboard, } \\
\text { mouse }\end{array}$ \\
\hline Communication equipment & $\begin{array}{l}\text { Television cameras, telephones for cellular } \\
\text { networks or for other wireless networks }\end{array}$ \\
\hline $\begin{array}{l}\text { Consumer electronic } \\
\text { equipment }\end{array}$ & Videogame consoles, digital cameras \\
\hline $\begin{array}{l}\text { Miscellaneous ICT } \\
\text { components and goods }\end{array}$ & Optical media, electronic integrated circuits \\
\hline $\begin{array}{l}\text { Manufacturing services for } \\
\text { ICT equipment }\end{array}$ & $\begin{array}{l}\text { Communication equipment manufacturing } \\
\text { services }\end{array}$ \\
\hline $\begin{array}{l}\text { Business and productivity } \\
\text { software and licensing services }\end{array}$ & Network software, online software \\
\hline $\begin{array}{l}\text { Information technology } \\
\text { consultancy and services }\end{array}$ & Website hosting services \\
\hline Telecommunications services & Broadband Internet access services \\
\hline $\begin{array}{l}\text { Leasing or rental services } \\
\text { for ICT equipment }\end{array}$ & $\begin{array}{l}\text { Leasing or rental services concerning } \\
\text { computers without operator }\end{array}$ \\
\hline Other ICT services & $\begin{array}{l}\text { Engineering services for telecommunications } \\
\text { and broadcasting projects }\end{array}$ \\
\hline
\end{tabular}

As we have noted before, information and communication technology has made an impact on many aspects of our lives, including our personal lives. In fact, ICT is transforming social and family relationships by changing the way they are developed (Bernabeu, Esteban, Gallego, \& Rosales, 2011). Nowadays it is possible to connect with any person, anywhere in the world, and this has resulted in substantial changes (Laespada, 2010), such as the emergence of interactive communication. Therefore, 
"the diffusion of Internet, mobile communication, digital media, and a variety of tools of social software have prompted the development of horizontal networks of interactive communication that connect local and global in chosen time" (Castells, 2007, p. 246).

According to Scolari (2008), interactive communication is communication mediated by digital technologies, such as computers, mobile phones, video games, and the Internet. The prerequisite for interactive communication is that the digital technology used allows interactivity. Interactivity is a characteristic of communication settings related to all the elements of the communication process (emitter, receiver, message and channel) that allows interchangeable communication roles between communicator and recipient (Rafaeli, 1990). So, interactive communication is a communication process mediated by a digital technology in which two or more people can speak, listen and think. If one of these elements is missing, there is no interactive communication (Berenguer, 2004).

Moreover, it can take place through communication forms, such as instant messaging, chat rooms, social media sites and email, and through information and communication technologies, such as computers, mobile phones, video games and the Internet (see Table 2). Finally, interactive communication may involve users who are strangers, acquaintances, friends, family, or colleagues (Lin, 2009). Consequently, it has become an important advancement in our society as it offers a lot of possibilities and benefits for its users. People who are thousands of miles away can stay in touch and interact instantaneously, something that would otherwise be unthinkable. Thus, interactive communication keeps individuals connected in society (Lin, 2009). 
RISKS OF INTERACTIVE COMMUNICATION IN ADOLESCENTS

DIGITAL LITERACY DIAGNOSIS AND INTERVENTION

Table 2.

Classification of interactive communication forms and their functions

\begin{tabular}{|c|c|c|}
\hline $\begin{array}{l}\text { Communication } \\
\text { form }\end{array}$ & ICT used & Examples of functions enabled \\
\hline Email & $\begin{array}{l}\text { Computer, } \\
\text { smartphone and } \\
\text { tablet }\end{array}$ & $\begin{array}{l}\text { Write, store, send, and receive asynchronous } \\
\text { messages; can include attachments of files } \\
\text { (e.g., Gmail) }\end{array}$ \\
\hline Instant messaging & $\begin{array}{l}\text { Computer, } \\
\text { smartphone and } \\
\text { tablet }\end{array}$ & $\begin{array}{l}\text { Synchronous exchange of messages that are } \\
\text { primarily in text but can include } \\
\text { attachments of files (e.g., WhatsApp) }\end{array}$ \\
\hline Chat rooms & Computer & $\begin{array}{l}\text { Synchronous (public or private) } \\
\text { conversations with more than one user that } \\
\text { primarily involve text }\end{array}$ \\
\hline Blogs & Computer & $\begin{array}{l}\text { Websites with entries that can be either } \\
\text { public or private only for users authorised }\end{array}$ \\
\hline $\begin{array}{l}\text { Social } \\
\text { networking sites }\end{array}$ & $\begin{array}{l}\text { Computer, } \\
\text { smartphone and } \\
\text { tablet }\end{array}$ & $\begin{array}{l}\text { Online utilities that allow users to create } \\
\text { profiles (public or private), to form a } \\
\text { network of friends and interact via public } \\
\text { and private means (such as messages) and to } \\
\text { post user-generated content such as photos } \\
\text { and videos (e.g., Facebook) }\end{array}$ \\
\hline $\begin{array}{l}\text { Video and } \\
\text { photo sharing }\end{array}$ & $\begin{array}{l}\text { Computer, } \\
\text { smartphone and } \\
\text { tablet }\end{array}$ & $\begin{array}{l}\text { Allows users to upload, view, and share } \\
\text { video and photos (e.g., YouTube and Flickr) }\end{array}$ \\
\hline $\begin{array}{l}\text { Massively } \\
\text { multiplayer online } \\
\text { computer games }\end{array}$ & Computer & $\begin{array}{l}\text { Online games that can be played by large } \\
\text { numbers of players simultaneously (e.g., } \\
\text { World of Warcraft) }\end{array}$ \\
\hline Virtual worlds & Computer & $\begin{array}{l}\text { Online simulated } 3 \text {-D environments } \\
\text { inhabited by players who interact with each } \\
\text { other via avatars (e.g., Second Life) }\end{array}$ \\
\hline
\end{tabular}

Nevertheless, it should be pointed out that interactive communication is not a widely accepted term and some scholars use other terms, such as computermediated communication (Favotto et al., 2017; Hudson, Fetro, \& Ogletree, 2014; Spitzberg, 2006), technology-mediated communication (Bunz, Curry, \& Voon, 2007; 
Janssen et al., 2013) or online communication (Koutamanis, Vossen, Peter, \& Valkenburg, 2013; Subrahmanyam \& Greenfiel, 2008; Trepte, Masur, \& Scharkow, 2017; Valkenburg \& Peter, 2009) with the same meaning. Thus, Mahmoud and Auter (2009) consider computer-mediated communication an interactive communication format and Spitzberg (2006) defines it as "any interpersonal communication process mediated through computer-assisted technologies", such as cellular phones, instant messaging, websites or emails (p. 631). However, Bunz et al. (2007) argue that the term computer-mediated communication is self-limiting and narrow. According to them, the term technology-mediated communication should be used instead, as it includes technologies, such as cell phones, that are not associated with the desktop computer. Therefore, as there is no clear distinction between concepts, in this study we will use the terms "interactive communication" and "online communication" interchangeably.

\subsubsection{Integration and use of information and communication technology}

As we said, information and communication technology is increasingly accessible to the population. Consequently, the number of individuals online grows every year. ONTSI (2013) estimated that, in 2012, 2.5 billion people were Internet users (38.8 percent of the global population), but in 2017, according to ITU (2017), the number of individuals using the Internet exceeded 3.5 billion (48.o percent of the world population). That is, nearly half of the world's population now uses the Internet, although there are large differences between different regions of the world. Thus, Europe has the highest level of Internet penetration, since 76 percent of the population are users, followed by America with 71 percent penetration. At the other end of the scale, Africa is the region where there is the lowest level of Internet penetration, 29 percent, followed by Asia-Pacific, 46 percent, and Middle East, 60 percent (Hootsuite, 2017). In Figure 1, we can see the evolution of Internet use across the world in recent years. 


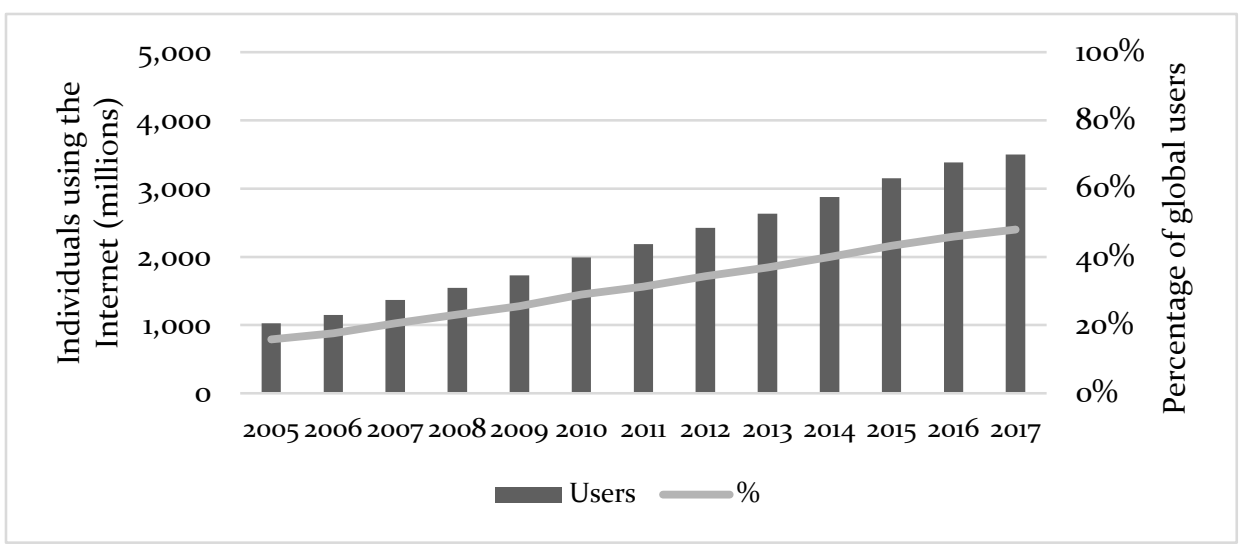

Figure 1. Evolution of Internet user across the world 2005-2017.

Adapted from ITU (2017)

As the number of Internet users across the world has increased, so has time spent online. Nowadays, the average user spends six hours each day using the Internet (Hootsuite, 2018). Only three years earlier, the average amount of time was four hours and 25 minutes (Hootsuite, 2015). Thus, the Internet has increasingly become embedded in everyday life. More and more people are using the Internet and they spend increasing amounts of time on it.

Furthermore, and as we mentioned before, the use of ICT has made an impact on the way social and family relationships are developed. Consequently, interactive communication has gained importance in society. A concrete example is the increase of social media users around the world. As we can see in Figure 2, in only eight years the number of users has tripled, reaching nearly 3.2 billion active social media users. As a point of interest, Facebook is currently the most successful social network platform with 2.17 billion active users around the world (Hootsuite, 2018). 


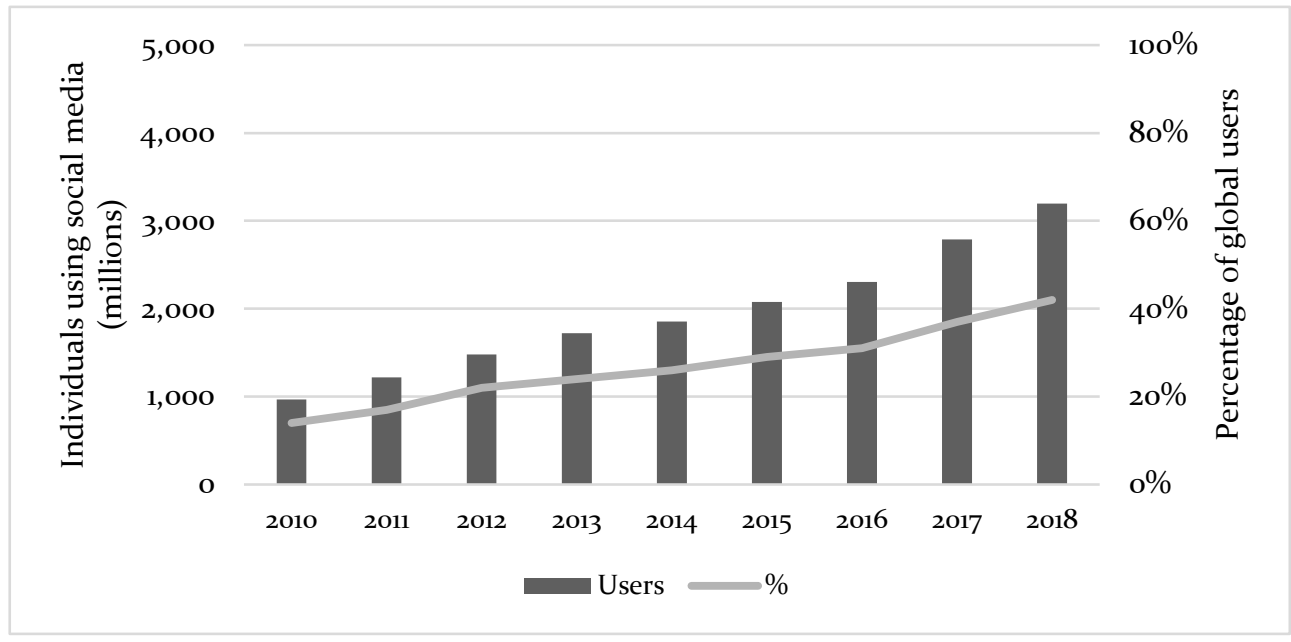

Figure 2. Evolution of active social media use across the world 2010-2018. Adapted from Hootsuite (2018)

In the case of Spain, 39.42 million people are Internet users, a penetration of 85 percent. This percentage is similar to other European countries, such as Poland ( 78 percent), Ireland (82 percent), France (88 percent) and Belgium (89 percent; Hootsuite, 2018). Moreover, 69 per cent of the Spanish population aged 16 to 74 uses the Internet every single day (ONTSI, 2018b). As we can see in Figure 3, the percentage has greatly increased in recent years, since in 2005 only 20 percent of population used the Internet daily. On the other hand, the percentage of users increases as age decreases. As we will see in the next section, the younger the individual, the more they use the Internet.

Although the Spanish percentage of Internet penetration is similar to that in other European countries (and higher than the global average), the average Spanish user "only" spends five hours and 20 minutes daily using the Internet, compared with a world average of six hours. With regards to social media, in Spain the penetration rate is $58 \%$ and the average daily time spent using these platforms is one hour and 38 minutes. Furthermore, the most common online activities among Spanish people are 
looking for information, reading news online, visiting social networks, using instant messaging, using email, watching videos and playing games (Fundación Telefónica, 2017; Hootsuite, 2018; ONTSI, 2018a).

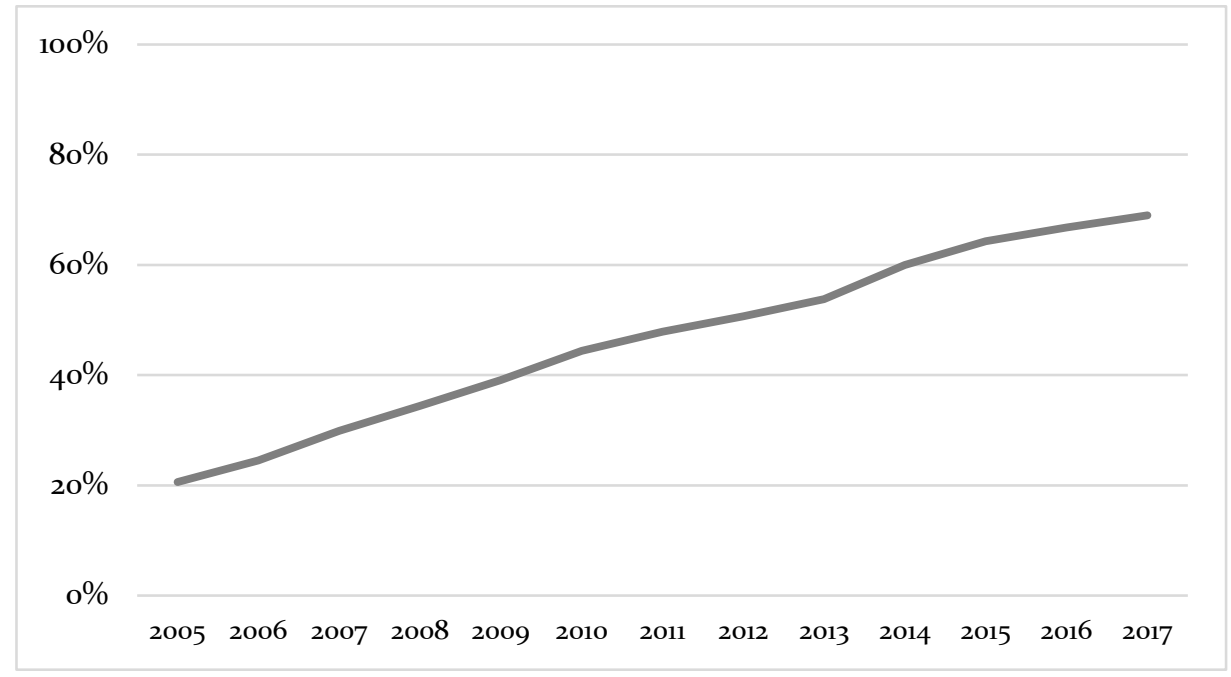

Figure 3. Evolution of daily Internet user in Spain 2005-2017. Adapted from ONTSI (2018)

In conclusion, as we deduced from data, nowadays ICT use is very widespread. Furthermore, as we mentioned at the beginning of this chapter, we have seen how the use of ICT has had an impact on aspects such as leisure and personal communication; an average Spanish user spends five hours and 20 minutes daily using the Internet and one hour and 38 minutes daily using social media platforms. Nevertheless, the target population for the present study is adolescents. Although these statistical data are interesting to create a full picture of the situation, from now on, we will focus on minors. 


\subsection{Adolescents and their Use of Interactive Communication}

Young people are fully immersed in the knowledge society. They are at the forefront of using ICT and there are very few of them who do not use it. In fact, $96 \%$ of European adolescents aged $16-19$ years (95\% in the case of Spain) use the Internet at least weekly and most of them connect to the Internet daily (Eurostat, 2016). Similarly, 92\% of American teens aged 13-17 go online daily, with 24 percent of them using the Internet almost constantly (Lenhart, 2015). Thus, "the ubiquity of the Internet in the everyday lives of European youth is leading to its deeper incorporation in their daily routines and practices" (Mascheroni, Murru, \& Görzig, 2012, p. 68). To give an idea of the pioneering role of young people in using new digital devices, in Figure 4 we can see the proportion of young people aged 15-24 using the Internet compared to the proportion of the total population using the Internet in different regions.

Adolescents have grown up in a digital world and the Internet is more and more embedded in their lives (Mascheroni et al., 2012). Thus, UK adolescents aged 1215 years spend close to 21 hours per week online and around 18 hours using a mobile phone (Ofcom, 2017). Consequently, young people engage daily and spend much time

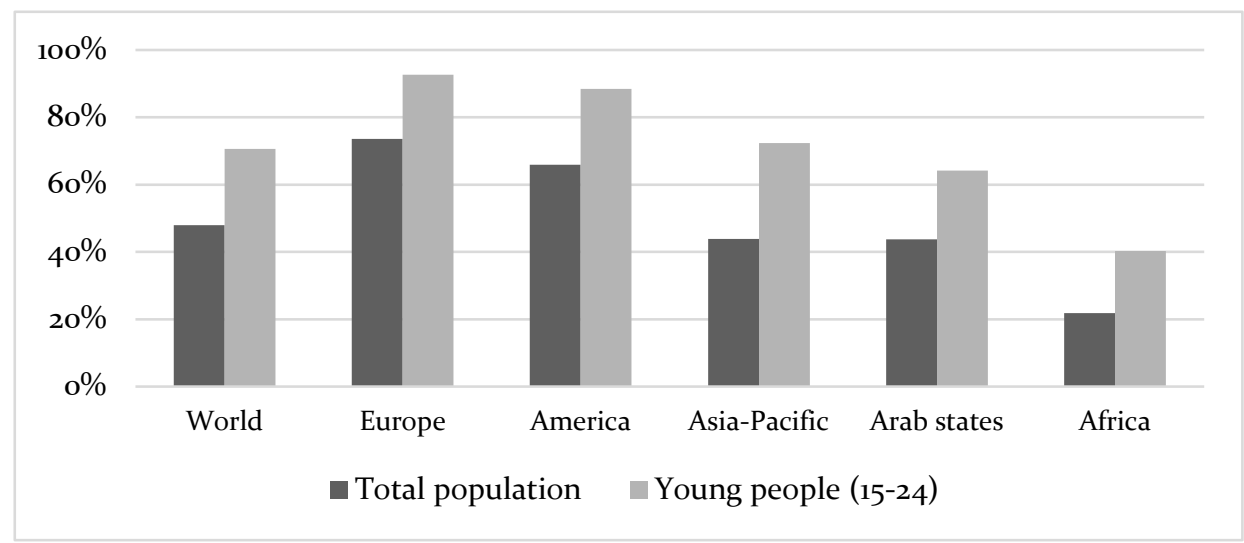

Figure 4. Proportion of Internet users, by age.

Adapted from ITU (2007) 
on a broad range of online activities, such as looking for information for schoolwork, sending and receiving messages in instant messaging applications, accessing social media platforms, playing games and watching videos on platforms such as YouTube (Mascheroni \& Ólafsson, 2014).

As we mentioned previously, the use of ICT enables interactive communication. This sort of communication can take place through instant messaging, e-mail, blogs, social networking, and sites for sharing photos and videos (Subrahmanyam \& Greenfiel, 2008), and it allows adolescents to connect with their friends or family members regardless of physical distance (Favotto et al., 2017). Young people use it almost daily for various purposes, such as leisure, relationships with friends or family and educational purposes.

According to Valkenburg and Peter (2011), online communication is so attractive to them because it enhances the controllability of self-presentation and selfdisclosure due to its anonymity, asynchrony, and accessibility. First, asynchrony allows adolescents to change and reflect on what they write before they send their messages. Secondly, online anonymity may lead to less concern about their physical appearance. Thirdly, accessibility allows adolescents to interact with peers whom they may not have seen for a long time or whom they cannot meet easily in their lives. Therefore, adolescents use online communication to reinforce existing relationships, both friendships and romantic relationships, and to build new friendships with strangers (Subrahmanyam \& Greenfiel, 2008). In addition, the fact that online communication is fast-paced and less expensive than traditional technologies has promoted its adoption by teens (Bryant, Sanders-Jackson, \& Smallwood, 2006).

Most adolescents use some form of online communication daily. In fact, it has become a "social norm among groups of young people, even in early adolescence" (Favotto et al., 2017, p. 7). Consequently, seven in ten European children aged 9-16 have visited a social networking profile in the past month, and six in ten have used 
instant messaging (Mascheroni \& Ólafsson, 2014). Similarly, three in four UK (12-15 years old) and American (13-17 years old) adolescents have a profile on a social media site (Lenhart, 2015; Ofcom, 2017). As with the general population, Facebook is reported as the most used platform by adolescents. However, the use of social media is diversifying (Lenhart, 2015; Mascheroni \& Ólafsson, 2014; Ofcom, 2017) and other common social media sites among young people are Snapchat and Instagram.

In conclusion, these data demonstrate the relevance that ICT has on adolescents' lives. As we shall see, the Internet and digital devices, such as smartphones, have made an impact on aspects such as relationships, which are also developed using social media and instant messaging platforms; learning activities, which can be complemented by looking for information online; and entertainment, since adolescents spend most of their leisure time surfing the Internet or watching videos online.

In the case of Spain, children and young people have also increased their use of digital technologies in the last few years. In 2001, 26 percent of Spanish children (aged 6-16) used the Internet, with a daily average of 4 minutes (Beentjes et al., 2001). As we can see in Figure 5, the proportion of Spanish children (aged 4-13) that had

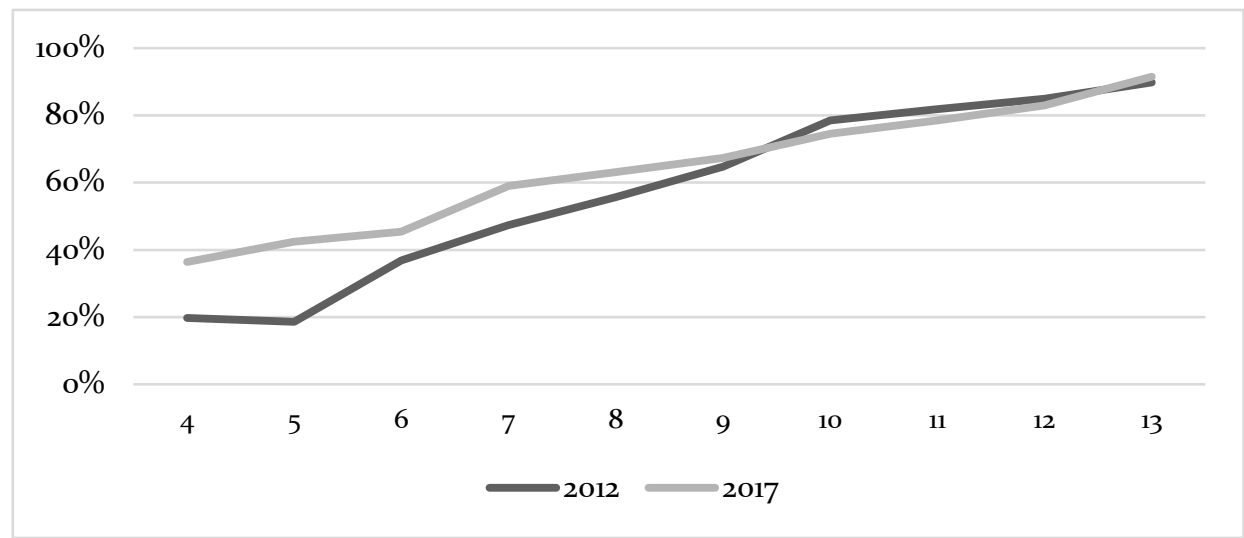

Figure 5. Internet penetration rate among Spanish children aged 4-13 years Adapted from AIMC (2017) 
RISKS OF INTERACTIVE COMMUNICATION IN ADOLESCENTS.

DIGITAL LITERACY DIAGNOSIS AND INTERVENTION

access to the Internet increased to 57.4 percent in 2012 (AIMC, 2012) and 64.7 percent in 2017 (AIMC, 2017).

Rates increase in the case of older adolescents. As we can see in Figure 6, the percentage of Spanish adolescents that use the Internet is close to 100 per cent. Nearly all adolescents use the Internet, use computers and have mobile phones (INE, 2017). Therefore, the older the minor, the more frequent the use of ICT. For instance, in the case of 10 year old children, one in four children have their own mobile phone, but for 14 year old adolescents, the proportion rises to nine in ten adolescents (INE, 2017).

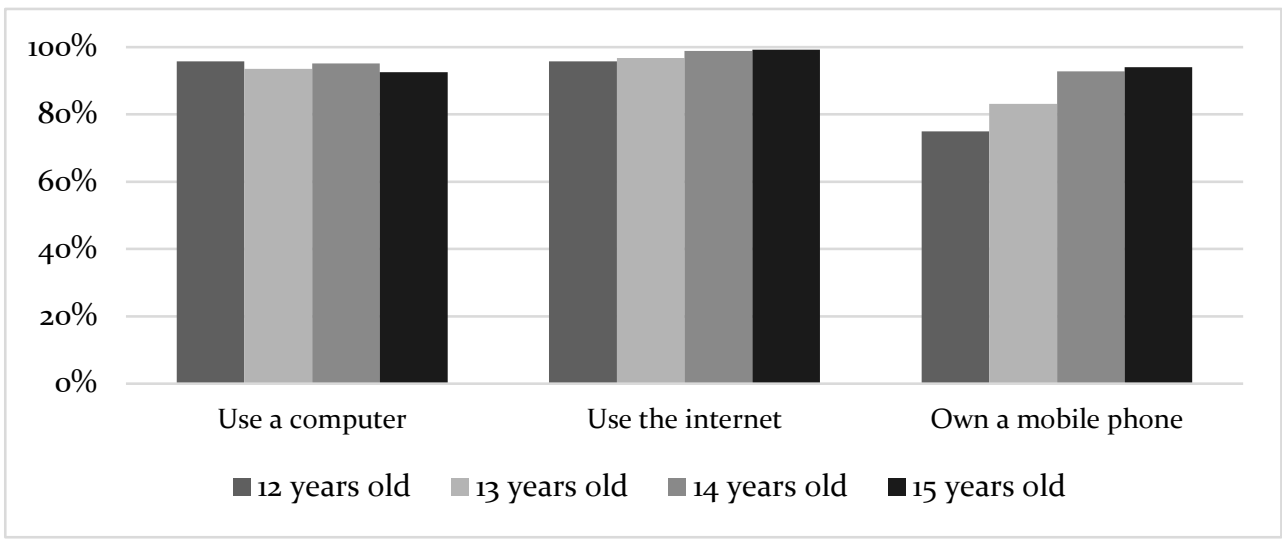

Figure 6. Proportion of Spanish adolescents (aged 12-15) using ITC Adapted from INE (2017)

The more important reasons for using the Internet among Spanish adolescents are related to interactive communication: using instant messaging and accessing social media sites (Golpe Ferreiro et al., 2017). As happens in other countries, Facebook is the most used social media site among adolescents, followed by Instagram and Twitter (Garmendia, Jiménez, Casado, \& Mascheroni, 2016). More than nine in ten Spanish adolescents aged 12-17 use instant messaging services, mainly WhatsApp, and have a social media profile. Moreover, six in ten adolescents access social media 
platforms daily (Golpe Ferreiro et al., 2017). Accordingly, the Internet, social media sites and instant messaging services play an important role in adolescents' lives.

Given all these data, we can confirm that young people have a pioneering role in the use of ITC. This can also be demonstrated by the fact that Spanish households with children under the age of 16 have more technological equipment than households without children (see Figure 7).

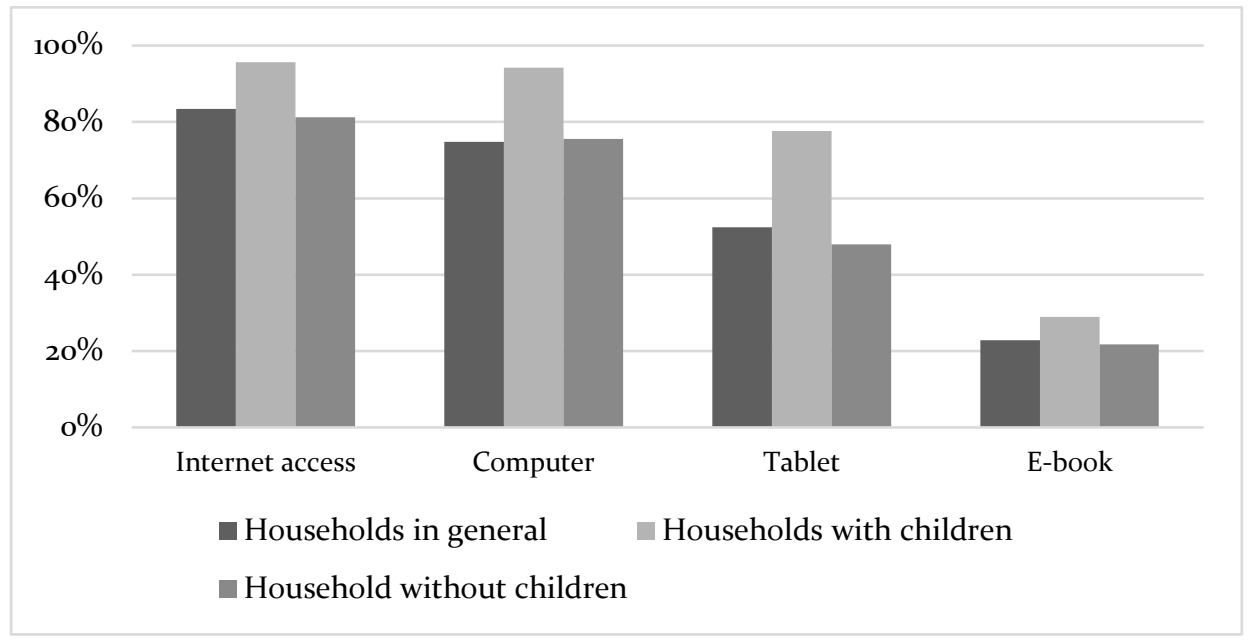

Figure 7. Technological equipment in Spanish households. Adapted from ONTSI (2018)

In conclusion, information and communication technology is embedded in every aspect of our society, especially in the case of adolescents. Young people have completely integrated the Internet, smartphones, social media sites and instant messaging services into their daily routines.

\subsection{Impact of ICT on Adolescents' Lives}

As we saw in the previous epigraph, adolescents have increased their use of interactive technologies and have fully integrated them into their lives. In consequence, 
technology has changed the way adolescents learn, entertain themselves and, as we have seen, communicate with their friends and relatives.

Regarding education, a study conducted several years ago already revealed that teens perceived the Internet as a useful tool for doing homework (Lenhart, Maya, \& Graziano, 2001). According to this, $94 \%$ of adolescents who had Internet access used it for school research and $78 \%$ believed the Internet helped them with homework. Moreover, they chose to search for information from electronic sources rather than in libraries. Similarly, one of the most common uses of the Internet for Spanish adolescents is for school assignments (Padilla et al., 2015).

However, negative effects also emerge from the educational use of ICT. By using several media simultaneously or using media while doing non-media activities, such as studying or doing homework, they are engaging in what is known as media multitasking (Baumgartner, Weeda, van der Heijden, \& Huizinga, 2014). The downside is that research has shown that media multitasking during academic activities is negatively related to academic performance (van der Schuur, Baumgartner, Sumter, \& Valkenburg, 2015).

As regards to entertainment, at present "teens spend more time with media that they do at school" (Valkenburg \& Piotrowski, 2017, p. 1) and, therefore, they also use technology for leisure. Eight in ten Spanish adolescents watch videos online and play video games (Padilla et al., 2015). Other common online activities are listening to music (Ferrari, 2013) or downloading films (Mascheroni \& Ólafsson, 2014). Consequently, digital technology has also changed the way adolescents spend their free time.

In addition, as minors spend more and more time using digital technologies, the amount of technological equipment in their rooms has risen, and this has led to a bedroom culture (Rodríguez-de-Dios \& Igartua, 2016). Bedroom culture is a 
phenomenon in which "youth spend more and more time with media in their private spaces, out of their parents' sight" (Valkenburg \& Piotrowski, 2017, p. 251).

As we can check in Figure 8, children and young people spend a lot of time in their rooms, where they use information and communication technology (Bovill \& Livingstone, 2001). In fact, the "use of the Internet among children in Europe is more frequent in their own bedrooms than in any other room in the home" (Mascheroni et al., 2012, p. 62) and there is an association between the amount of technology that minors have in their rooms and the proportion of time they spend there. Thus, having more technological devices is related to spending more time alone in bedrooms (Bovill \& Livingstone, 2001). In this sense, boys, older minors and the children of more highly educated parents are more likely to have online private access from their own bedrooms (Mascheroni et al., 2012).

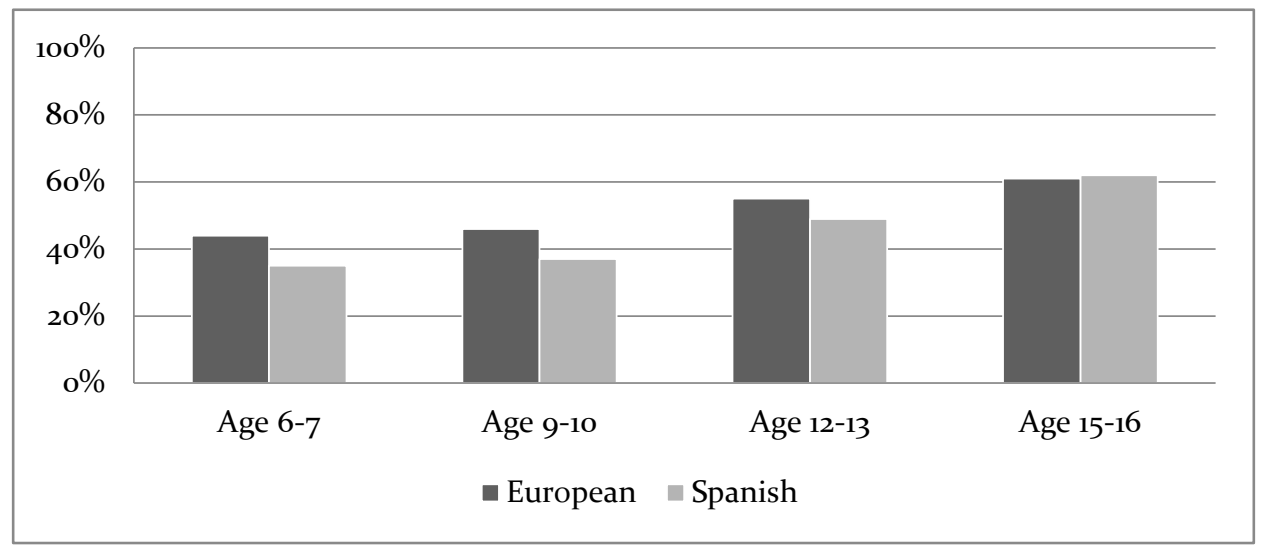

Figure 8. Percentage of European and Spanish minors that spend half or more of waking time at home in their own room, by age Adapted from Bovill \& Livingstone (2001)

This increasing privacy characterising Internet usage through personal and mobile devices in bedrooms makes "any sort of parental monitoring or sharing of media practices more difficult" (Mascheroni et al., 2012, p. 62). Consequently, parental 
RISKS OF INTERACTIVE COMMUNICATION IN ADOLESCENTS.

DIGITAL LITERACY DIAGNOSIS AND INTERVENTION

controls in terms of time, content, or uses of the media are much lower than previously (Garitaonandia et al., 2005).

As we have seen in this chapter, the use of ICT offers advantages to users. For example, we saw that interactive communication keeps individuals connected within society (Lin, 2009). However, this technology also has potential negative effects that present challenges for parents, educators and researchers. For example, when using social media sites, we must decide what information (name, address, personal pictures, etc.) we want to be public or private, and with whom we want to share it (Gabelas, 2010). Badly handled online sharing of personal information can lead to loss of individual privacy, since this private information can be exposed to any individual or organisation (Area Moreira, 2001).

Even though "young people are very sophisticated users of technology and often lead the way in adapting new technologies to everyday use, their technological savvy, combined with the ability to be online without much adult supervision, can lead to behaviours that are high risk" (Agatston et al., 2007). These risks and disadvantages are of particular concern in the case of minors (Rodríguez-de-Dios \& Igartua, 2014). They are a part of the population that requires special protection as they may not have sufficient resources to cope with the risks and, at the same time, to take advantage of the opportunities that technology offers (Tolsá, 2012).

Since the tendency of young people to spend much of the time with technology in their own rooms makes parental protection efforts more difficult, other solutions for ensuring online safety have been proposed. Some researchers have suggested that adolescents should acquire digital skills in order to know how to effectively address these risks and obtain more benefits from the digital environment (Cernikova, Dedkova, \& Smahel, 2018; Rodríguez-de-Dios \& Igartua, 2016; Sonck \& de Haan, 2014; Sonck et al., 2011). Consequently, in the following chapters we will focus on digital skills, on online risks and on online opportunities. 


\subsection{Summary and Conclusions}

In this chapter, we have analysed the integration of ICT into society and its effects, especially on adolescents. First, we have examined some relevant terms for the present study: knowledge society, information and communication technology, and interactive communication. Furthermore, we have given some statistical data that show how the number of individuals online is constantly increasing. In addition, not only has the number of Internet users increased, but so too has the amount of time spent online. Consequently, as ICT use is very widespread, this has had an impact on many aspects of life, such as the way social and family relationships are developed. Thus, many people use online communication to keep in touch with friends and relatives. Since the present thesis project has been developed in Spain, we have briefly focused on the data from this country, where an average Spanish user spends 5 hours and 20 minutes daily using the Internet and 1 hour and 38 minutes daily using social media platforms.

Secondly, we have aimed our attention at adolescents, who are increasingly using information and communication technology too. More than nine in ten young people use the Internet daily. At first, they did this through computers, but nowadays, smartphones are more commonly used to access the Internet. In Spain, the percentage of adolescents that use the Internet is close to 100 per cent. Moreover, nine in ten young people use instant messaging services and have a social media profile. Thus, we conclude that penetration rates are high.

As more and more daily activities are being mediated and take place online (Mascheroni et al., 2012), ICT has widely impacted on adolescents' lives. Throughout the chapter we have mentioned the changes that have taken in place in the way that young people study, learn, communicate with their friends and spend their free time. Nonetheless, technology is also related to some negative effects that can be increased because of the phenomenon of bedroom culture. Thus, the fact that young people 
RISKS OF INTERACTIVE COMMUNICATION IN ADOLESCENTS.

DIGITAL LITERACY DIAGNOSIS AND INTERVENTION

spend more and more time in their own rooms using digital media makes parental mediation more difficult. Consequently, we have ended the chapter by emphasising the relevance of digital skills for adolescents. In this sense, we should remember that, at the beginning of the chapter, we have already pointed out the importance of such skills in the knowledge society for using digital technology effectively.

Considering all of the above, in the next two chapters we will see what digital literacy, digital skills, online risks and online opportunities there are, and what the relationship is between them. 


\section{Chapter 2.}

\section{DigiTAL LITERACY AND}

DIGITAL SKILLS

I

$\mathrm{n}$ the last few years, research related to digital literacy and digital skills has grown exponentially. The ongoing development of digital devices and their presence in our daily lives makes digital skills essential in a range of professional occupations, for different aspects of people's lives and in order to be successful in our society (Bunz et al., 2007; Vandoninck, d'Haenens, \& Donoso, 2010). In the case of children and adolescents, researchers, parents and teachers have been concerned about the consequences that living in an increasingly digitised world may have for them (Patchin \& Hinduja, 2010a; Sonck, Kuiper, \& de Haan, 2012; Staksrud et al., 2013; Teimouri et al., 2014). Therefore, there has been growing interest in researching whether minors have developed the digital skills that are needed to function effectively in this environment.

Consequently, the purpose of the present chapter is to review literature on digital literacy and digital skills. Firstly, we will look at the definition of digital literacy and other types of literacy with which digital literacy shares conceptual ground, such as information and media literacies. Secondly, we will also review the different specific

${ }^{2}$ Part of this chapter is published in:

Rodríguez-de-Dios, I., \& Igartua, J.-J. (2016). Skills of Digital Literacy to Address the Risks of Interactive Communication. Journal of Information Technology Research (JITR), 9(1), 54-64. https://doi.org/10.4018/JITR.2016010104 
RISKS OF INTERACTIVE COMMUNICATION IN ADOLESCENTS.

DIGITAL LITERACY DIAGNOSIS AND INTERVENTION

digital skills that make up the broader concept of digital literacy. Finally, we will analyse the different digital literacy measures that have been developed so far.

\subsection{What is Digital Literacy? Antecedents and Definition}

As we saw in the previous chapter, the use of digital technology and interactive communication has had a great impact on society. Over the last few years, the way we work, socialise, communicate, entertain ourselves, relax and live has changed due to technological advancements. Another aspect that has also changed because of these advancements is the concept of literacy.

Traditionally, the term literacy has referred to the ability to read, write and understand (Bawden, 2001). Thus, "it is the fundamental act of cognition" (Gilster, 1997, p. 1). This term has been widely used over many years and it has evolved while society has expanded throughout history, because it is a social practice that evolves and changes as the needs and means of the dominant social culture are transformed (Area, Gros, \& Marzal, 2008). Accordingly, with the passage of time and due to the evolution of technology, which has always defined literacy (González, 2012), different types of literacy have emerged, such as information literacy, media literacy and digital literacy.

The concept of digital literacy has been developed later than the other literacies. For this reason, it draws on and shares conceptual ground with these literacies (Bawden, 2008; Koltay, 2011; A. Martin, 2005). Consequently, before discussing the concept of digital literacy, we must introduce the other types of literacies (information literacy, media literacy, news media literacy and multiliteracy), since they have influenced its development. 


\subsubsection{Information literacy}

The concept of information literacy has developed since the late 1980 s as a re-focusing of bibliographic instruction because of the emergence of the World Wide Web as an enormous source of information (A. Martin, 2008). It can be defined as the ability to identify, locate, evaluate and use information (Thompson, 2003). Nonetheless, although it was promoted as a result of the advent of digital technology, "information literacy is not simply about digital information" (A. Martin, 2008, p. 160). Thus, it refers to the ability to identify, locate, evaluate and use information in any channel or medium, and not only in the digital environment.

The first definitions of this term had a work-related focus and were related to the effective use of information for problem solving tasks (Bawden, 2008). Some years later, the importance of information in society would be highlighted and information literacy would be defined as a "thematic synthesis of the skills that individuals will need to live in the information age" (Doyle, 1994, p. 7). Some of these skills included recognising the need for information, identifying possible sources of information, developing successful search strategies, evaluating information and organising information for practical application, among others (Doyle, 1994). Accordingly, information literacy can also be defined as the necessary skills to identify a need for information, to locate and select the best information sources, to obtain relevant information, to evaluate the information and to manage it legally and ethically (González, 2012).

Considering the above, the aim of information literacy would be to develop users competent in finding, selecting and evaluating information in different channels and information sources. Consequently, an information literate individual would know how to formulate an efficient search strategy and how to manage information (Area et al., 2008; Bernabeu et al., 2011). 
RISKS OF INTERACTIVE COMMUNICATION IN ADOLESCENTS.

DIGITAL LITERACY DIAGNOSIS AND INTERVENTION

\subsubsection{Media literacy}

The influence of this concept expanded in the late 1990s (Bawden, 2001) and it has attracted scholars who are concerned about the influence of media on individuals and society (Potter, 2013). Thus, its importance is not only justified by the amount of media exposure, but also by the "vital role of information in the development of democracy, cultural participation and active citizenship" (Koltay, 2011).

Media literacy is generally defined as the ability to analyse, evaluate and produce media messages (Martens, 2010). Thus, it includes analytic competences, such as an understanding of languages and representations, critical elements and creation and production competences (Livingstone, 2004). Similarly, it can be defined as the analytical and reflective use and understanding of print and electronic media, such as print journalism, radio and television. This understanding also includes characteristics of media and their messages, such as their aesthetic components and the regulatory aspects and institutional structures that surround them (J. A. Brown, 2001). Individuals need to be aware of media industries, media messages and media effects (Potter, 2004) and this implies "critical thinking in assessing information gained from the mass media" (Bawden, 2001, p. 225). As there is no one common definition of media literacy, Potter (2013) establishes some common themes on which there is general agreement: mass media exert a wide range of effects on individuals, who are more susceptible if they are passive, and on larger social structures. Consequently, media literacy, a multi-dimensional construct which must be developed, would empower individuals to gain greater control over these effects. Accordingly, media literacy is considered essential for all individuals who consume media (Koltay, 2011) and a key means by which they participate in society (Livingstone, 2004).

Finally, media literacy and information literacy are related as both promote the idea of learning to use and evaluate media or information sources in a specialised way (Bawden, 2001; Koltay, 2011; Lankshear \& Knobel, 2008). 


\subsubsection{News media literacy}

News media literacy (or news literacy) is a relatively recent concept that arises from the more general concept of media literacy and focuses on a specific media message, news. It can be briefly defined as the ability to apply core media literacy skills to news (Maksl, Craft, Ashley, \& Miller, 2017)

More specifically, news media literacy refers to people's ability to identify and evaluate the evidence for, credibility of and reliability of news content, to differentiate reliable and credible information from unverified and biased information, to know about media content, industries and effects and to be aware of the influence of their own news consumption on themselves (Maksl, Ashley, \& Craft, 2015; Maksl et al., 2017). As happened with media literacy, the importance of news media literacy arises from the unique role that news has in democratic societies. Thus, citizens usually make their democratic decisions based on the information that they receive from news (Vraga, Tully, Kotcher, Smithson, \& Broeckelman-Post, 2015).

Therefore, news literacy education usually focuses on three aspects related to news. The first, media productions, shows under which conditions and constraints news is produced. Secondly, the societal implication emphasises that journalism creates an informed public capable of making democratic decisions. Thirdly, critical thinking focuses on the responsibility of individuals to be critical consumers (Vraga et al., 2015). Consequently, a news literate person would be more sceptical about news content, would think deeply about media experiences, would have intrinsic motivations toward news consumption and greater knowledge about media content, industries and effects and, subsequently, would apply critical thinking skills to news consumption (Maksl et al., 2015, 2017).

Finally, as before, news media literacy shares conceptual terrain with information literacy and media literacy (Maksl et al., 2017). 
RISKS OF INTERACTIVE COMMUNICATION IN ADOLESCENTS.

DIGITAL LITERACY DIAGNOSIS AND INTERVENTION

\subsubsection{Multiliteracy}

The concept of multiliteracy (also known as multiple literacies, transliteracy or transmedia literacy) is based on the plurality of literacies. It includes a wide range of literacies: visual literacy, computer literacy, media literacy, technology literacy and cultural literacy (N. Cooper, Lockyer, \& Brown, 2013; Westby, 2010). Thus, it is a multimodal literacy that comprises traditional literacies and digital literacy and that includes "a set of skills, practices, values, priorities, sensibilities, and learning/sharing strategies developed and applied in the context of the new participatory cultures" (Scolari, 2018, p. 15).

The origin of the concept of multiliteracy is derived from the recent changes in the media ecology. It states that, in our multimodal society, individuals should be prepared, qualified and, ultimately, literate to use effectively the different media and languages that currently coexist (Area et al., 2008). Accordingly, this multimodal society with media, cultural and linguistic diversities, but global connectedness, makes it necessary than individuals are multiliterate (Westby, 2010). The idea of multiliteracy also considers that new media offer individuals the possibility to produce, share and consume content. Unlike when consuming traditional media, individuals are now prosumers, "active subjects who create new contents and share them in the digital networks" (Scolari, 2018, p. 14). Consequently, apart from traditional skills of information and media literacy, they need skills to produce, compose and share content via multiple media technologies, that is, multi-modal content (N. Cooper et al., 2013; Khadka, 2018; Scolari, 2018).

Therefore, this type of literacy arises from the confluence of the different media that have created a multi-modal society. The different possibilities that each media type offers to the users, such as being creators and producers of content, also implies the necessity for different skills. In this way, this concept alludes directly to the combination of all other literacies. 
To recapitulate, in Table 3 we present a summary of the definitions and objectives of the different types of literacies that we have seen so far and a brief introduction to digital literacy.

Table 3.

Types of literacies and their characteristics

\begin{tabular}{|c|c|c|}
\hline Literacy & Definition & Objective \\
\hline Information & $\begin{array}{l}\text { Ability to identify, locate, } \\
\text { evaluate and use information }\end{array}$ & $\begin{array}{l}\text { Develop users competent in } \\
\text { finding and selecting } \\
\text { information }\end{array}$ \\
\hline Media & $\begin{array}{l}\text { Ability to access, understand } \\
\text { and critically evaluate media } \\
\text { messages }\end{array}$ & $\begin{array}{l}\text { Develop critical consumers of } \\
\text { media }\end{array}$ \\
\hline News media & $\begin{array}{l}\text { Ability to apply core media } \\
\text { literacy skills to news }\end{array}$ & $\begin{array}{l}\text { Develop critical consumers of } \\
\text { news content }\end{array}$ \\
\hline Multiliteracy & $\begin{array}{l}\text { Ability to create, produce and } \\
\text { share content via the } \\
\text { different media technologies. }\end{array}$ & $\begin{array}{l}\text { Develop critical prosumers of } \\
\text { media content }\end{array}$ \\
\hline Digital & $\begin{array}{l}\text { Ability to use digital media to } \\
\text { access, manage and evaluate } \\
\text { resources, create media } \\
\text { expressions and communicate }\end{array}$ & $\begin{array}{l}\text { Develop critical, safe and } \\
\text { independent users of digital } \\
\text { media }\end{array}$ \\
\hline
\end{tabular}

Note. Author's elaboration from Koltay (2011), Maksl et al. (2017), Martin (2005), Scolari (2018) and Thompson (2003)

\subsubsection{Digital literacy}

In the 1990s a new concept of literacy arose due to the expansion of digital technology, telematics networks, and new representational languages, such as hypertext, multimedia and interactivity (Area et al., 2008): digital literacy (also known as eliteracy, technological literacy or ICT literacy).

The concept of digital literacy was first disseminated by Paul Gilster (1997), but its meaning has changed over the years and nowadays the terminology is still very confused (Bawden, 2008; Ilomäki et al., 2016; A. Martin, 2008), as there is no 
agreement between scholars. The first definitions of digital literacy referred only to an instrumental knowledge of hardware and software. Consequently, a person was digitally literate if they knew how to use, for example, a word processor on a computer. Later, some authors would use this term to refer to an ability to read and understand hypertextual and multimedia texts (Bawden, 2001).

Nowadays, scholars go beyond this approach of considering digital literacy as a mere ability to use a software package and also stress the importance of knowing how to use digital devices in a social context (Bawden, 2002; Gutiérrez, 2003). Accordingly, it "involves both expertise and skills in the mechanical use as well as knowledge and skills about using these devices for the purpose of communication, social networking, education, research, business enterprises, and so on" (Chisholm, 2006, p. 82). Moreover, some authors stress the idea that we cannot adequately understand these digital media if we persist in regarding them simply as a matter of machines, techniques, and software, due to the fact that the Internet, computer games, mobile phones and other contemporary technologies provide new ways of mediating and representing the world, and of communicating (Buckingham, 2008). Thus, the importance of technology is not the technology itself, but the intellectual, social, and ethical use we make of it (Area et al., 2008). Consequently, not only is the instrumental training of children relevant, but the development of cognitive and attitudinal skills for the use of digital technologies is also very important.

In this sense, digital literacy can also be defined as the ability to efficiently and accurately use digital information technologies and the information retrieved from them in a variety of contexts (Riel, Christian, \& Hinson, 2012). Sonck et al. (2012) add that "digital literacy refers not only to the ability to understand digital information, but also the ability to use digital information in a critical way, and for personal benefit as well as to participate and contribute to the digital society" (p.95). Moreover, Süss (2001) establishes that digital literacy consists of using a new medium 
so that it provides advantages over other forms of learning and, at the same time, being critical and aware of the impact of that environment on oneself. Although these definitions of digital literacy have slight differences in their scope or focal areas, their meanings actually overlap (Zhang \& Zhu, 2016).

Moreover, digital literacy shares conceptual grounds with other types of literacy, such as information literacy and media literacy. Therefore, it includes elements of other literacies, so that even some authors even state that it is composed by other literacies (Koltay, 2011). For example, many classifications of the skills that comprise digital literacy include an informational skill (Eshet-Alkalai, 2004; Sonck \& de Haan, 2014) that refers to the ability to identify, locate, evaluate and use information in the digital environment. In the same way, the dimension of media locus of control in the News Media Literacy Scale (Maksl et al., 2015) would be related to the critical dimension in digital literacy. Obviously, there are considerable differences between these types of literacy. We could say that media literacy tries to develop critical consumers of media; news media literacy, critical consumers of news content; information literacy, users competent in finding and selecting information; and digital literacy, critical, safe and independent users of digital media.

In view of the above, we rely on the following definition of digital literacy, as we consider that it reflects all previous conceptualisations and related forms of literacy and can be applied to new digital environments (such as social networking sites):

Digital literacy is the awareness, attitude and ability of individuals to appropriately use digital tools and facilities to identify, access, manage, integrate, evaluate, analyse and synthesize digital resources, construct new knowledge, create media expressions, and communicate with others, in the context of specific life situations, in order to enable constructive social action; and to reflect upon this process. (A. Martin, 2005, p. 135) 
RISKS OF INTERACTIVE COMMUNICATION IN ADOLESCENTS.

DIGITAL LITERACY DIAGNOSIS AND INTERVENTION

\subsection{Digital Literacy as a Set of Digital Skills}

First of all, it is important to note that, based on previous literature (Bawden, 2001; Brandtweiner, Donat, \& Kerschbaum, 2010; Claro et al., 2012; Eshet-Alkalai \& Chajut, 2009; Gui \& Argentin, 2011; Hargittai, 2008; Helsper \& Eynon, 2013; Koc \& Barut, 2016; S.-J. Lee \& Chae, 2012; Leung \& Lee, 2012a; Livingstone, 2004; Sonck \& de Haan, 2014; Wilson, Scalise, \& Gochyyev, 2015; Zhang \& Zhu, 2016), we consider that digital literacy consists of several specific digital skills that adolescents need to learn in order to function effectively in the digital environment. That is, we view digital literacy as a skill-based literacy.

Additionally, and as we noted above, digital literacy can have different characteristics depending on each author. For this reason, not all authors propose the same type of skills or dimensions when referring to this type of literacy. Therefore, while there is agreement on the importance of digital skills (Lau \& Yuen, 2014), "there is little consensus about precisely what knowledge and abilities are necessary for children to be literate" (Ba, Tally, \& Tsikalas, 2002, p. 5). Thus, several classifications of digital literacy coexist. Some of them will now be described.

In Table 4, we present Eshet-Alkalai's (2004) conceptual model that comprises five major digital skills: photo-visual, reproduction, branching, information and socio-emotional. Nevertheless, this classification does not include any skill related to online safety. Moreover, we consider that the branching skill would be part of the information skill, as looking for information in the digital environment implies being able to navigate through hyperlinks. In fact, other classifications include navigation as part of the informational skill (Ananiadou \& Claro, 2009; Ferrari, 2013). 
Table 4.

Conceptual model of digital literacy from Eshet-Alkalai (2004)

\begin{tabular}{ll}
\hline Digital skills & Definition \\
\hline Photo-visual & $\begin{array}{l}\text { Ability to work effectively with digital environments that use visual } \\
\text { representations, such as interfaces; being able to read and } \\
\text { understand instructions and messages represented visually. } \\
\text { Capacity to create new meanings or interpretations from existing }\end{array}$ \\
information in any form (text, graphic or sound). This is essential in \\
writing and visual art. \\
Ability to construct knowledge by a nonlinear navigation through \\
knowledge domains. New technologies present information in a \\
non-linear manner and users must be able to navigate through \\
these options for constructing knowledge. \\
Ability to evaluate and assess information properly and identify \\
false, irrelevant or biased information. \\
Ability to communicate effectively in online communication \\
platforms such as discussion groups and chatrooms, to \\
collaboratively construct knowledge and to be willing to share data \\
and knowledge with others.
\end{tabular}

In like manner, Area and Pessoa (2012) describe five dimensions that compose digital literacy: instrumental, cognitive-intellectual, socio-communicational, axiological and emotional (see Table 5). This model expands a previous model developed with four dimensions: instrumental, cognitive-intellectual, sociocommunicational and axiological (Area et al., 2008). Moreover, it is designed for adults with the aim that they can participate in the digital society as citizens. 
RISKS OF INTERACTIVE COMMUNICATION IN ADOLESCENTS.

DIGITAL LITERACY DIAGNOSIS AND INTERVENTION

Table 5.

Conceptual model of digital literacy of Area and Pessoa (2012)

\begin{tabular}{ll}
\hline Digital skills & Definition \\
\hline Instrumental & $\begin{array}{l}\text { Technical mastery of technology; that is to say, knowing how to } \\
\text { handle hardware and software (e.g., install software). }\end{array}$ \\
$\begin{array}{l}\text { Kognitive- } \\
\text { intellectual }\end{array}$ & $\begin{array}{l}\text { Knowledge and skills for effective use of information: search, select, } \\
\text { analyse, understand and recreate information; being able to } \\
\text { communicate with others through digital resources. }\end{array}$ \\
$\begin{array}{l}\text { Skills for the creation and dissemination of different types of texts } \\
\text { (hypertext, audio, iconic, three-dimensional); this also includes a }\end{array}$ \\
communicational \\
$\begin{array}{l}\text { positive attitude towards others: collaborative work, respect and } \\
\text { empathy in social networks. }\end{array}$ \\
$\begin{array}{l}\text { Development of criteria to critically analyse information; this also } \\
\text { includes the acquisition of ethical values for the use of technology } \\
\text { and communication. }\end{array}$ \\
$\begin{array}{l}\text { In digital environments, affects and emotions arise. We must learn } \\
\text { how to control negative emotions through empathy. }\end{array}$ \\
Emotional
\end{tabular}

Similarly, Monereo (2005) considers the existence of four basic sociocognitive skills for the knowledge society that integrate the concept of digital literacy: information, communication, collaboration and participation in public life (see Table 6). However, a technological or instrumental skill is not included in this model, even though it is a central basis for digital literacy (Ilomäki et al., 2016). Moreover, this model only considers the Internet.

Likewise, Cabero Almenara, Marín Díaz, and Llorente Cejudo (2012) propose a model of digital literacy that is composed of the following eight digital skills: technical-operative, languages, ideological, digital identity, communicative, aesthetics, economic and security-legislative (see Table 7). Nonetheless, we consider that some of these dimensions are not needed for minors, such as the economic one. 
Table 6.

Conceptual model of digital literacy of Monereo (2005)

\begin{tabular}{ll}
\hline Digital skills & Definition \\
\hline $\begin{array}{l}\text { Information } \\
\text { Communication }\end{array}$ & $\begin{array}{l}\text { Knowing when and why to use a certain search process, to use one } \\
\text { or another search engine and to select certain keywords. } \\
\text { Knowing how to use digital communication tools, such as email, } \\
\text { chat, videoconferences and forums. }\end{array}$ \\
$\begin{array}{l}\text { Collaboration } \\
\begin{array}{l}\text { Participation in } \\
\text { public life }\end{array}\end{array}$ & Knowing how to use digital collaborative tools. \\
Note. Author's elaboration from Monereo (2005)
\end{tabular}

Table 7.

Conceptual model of digital literacy of Cabero Almenara et al. (2012)

\begin{tabular}{ll}
\hline Digital skills & Definition \\
\hline $\begin{array}{l}\text { Technological- } \\
\text { operative }\end{array}$ & $\begin{array}{l}\text { Instrumental management and technological operation of } \\
\text { information technology and communication, regarding both } \\
\text { hardware and software. } \\
\text { Being able to use and understand how different types of languages, } \\
\text { systems, and symbolic codes converge: static image, multimedia, } \\
\text { audio, audio-visual and telematics. }\end{array}$ \\
$\begin{array}{l}\text { Ideological/political- } \\
\text { axiological }\end{array}$ & $\begin{array}{l}\text { Being aware that technology constructs a media reality that } \\
\text { determines how we see and understand the world. }\end{array}$ \\
Digital identity & $\begin{array}{l}\text { Being able to create and manage a digital identity. } \\
\text { Knowing the processes of production and distribution of messages; } \\
\text { differentiating the communicative uses of each technology depending } \\
\text { on the purpose; and knowing how to manage and process information. }\end{array}$ \\
Communicative & $\begin{array}{l}\text { Being able to recognise the quality and the aesthetic aspects of a } \\
\text { technological production. }\end{array}$ \\
Aesthetics & $\begin{array}{l}\text { Knowing the elements that link technology with business } \\
\text { development and the market. } \\
\text { Knowing the illegal and criminal actions that are performed } \\
\text { through communication networks, such as impersonation. }\end{array}$ \\
Security-legislative & $\begin{array}{l}\text { Konomic } \\
\text { Note. Author's elaboration from Cabero Almenara et al. (2012) }\end{array}$
\end{tabular}


On the other hand, if we consider children or adolescents exclusively, there are a few proposed digital literacy models. First, the EU Kids Online project (Sonck et al., 2011) mentions three general types of skills: instrumental (also known as basic or functional skills), informational (understanding, navigation, evaluation) and social (communication, self-disclosure, privacy). The work of this project was continued by the Net Children Go Mobile project (Mascheroni \& Ólafsson, 2014). However, in this case a different classification with four digital skills is used: instrumental, critical, safety and communication.

After this review, it is worth noting that the problem of some of these classifications is that they only consider the Internet and not the rest of the digital environment. Digital society is much more than the Internet, so limiting things only to the Internet ignores an important part of human actions in electronic space (Sevillano, 2009). Moreover, these classifications usually refer to the general public or adults. However, our target population is adolescents.

On the basis of the above, we define digital literacy as a set of necessary skills to make effective, critical, conscious and safe use of digital technology for communication, learning, work and entertainment purposes. Consequently, in addition to a technological skill, which basically allows the use of technology, other skills would be necessary to confirm that this use is effective, critical, conscientious and safe. Accordingly, considering previous studies, and taking into account the needs of minors, we propose a model with five different skills that are considered as being part of the broader concept of digital literacy, similar to previous research (Bunz, 2004; Helsper \& Eynon, 2013; S.-J. Lee \& Chae, 2012; Sonck \& de Haan, 2014; Zhang \& Zhu, 2016):

1. Technological or instrumental skill: ability to effectively use digital technologies; access to digital technology and knowledge about hardware and software components; familiarity with technology terms and competence to 
solve everyday technical problems. Therefore, this skill includes possessing technical and operational skills to use digital technology in minors' daily lives (Ng, 2012). Through this skill, the user can operate different software and hardware and is capable of adapting to innovations without problems. This dimension includes, for example, the handling capacity for technological innovations or the ability to distinguish which software is best suited for a purpose. In short, this skill implies an instrumental knowledge of digital tools, how to use them and for what purposes (Cabero Almenara et al., 2012; Iste, 2007; Riel et al., 2012). This skill basically allows minors to autonomously use technology on a daily basis. Moreover, it is an essential skill within digital literacy, since it is a pre-requisite skill for making critical or safe use of digital technology.

2. Communication skill: ability to communicate through digital technologies; knowing how to interact with other people on social media sites and how to adapt the message to a specific context, medium and purpose; knowledge about the different communicative tools, such as emoji and their communicative potential (Area \& Guarro, 2012; Cabero Almenara et al., 2012; Ferrari, 2012; Iste, 2007). According to Bakke (2010), it would also include the ability to tailor the message to the recipient. This skill also refers to the ability to read and understand an email or to being able to judge the intention of the communicator.

3. Information skill: in short, this refers to the ability to find information, obtain it, and evaluate its relevance in the digital environment. It also connects with the ability to classify, organise, process, obtain, evaluate and use information. This would include the use of search techniques, the evaluation of information, the organisation of this information through digital tools and the identification of authorship (Cabero Almenara et al., 2012; Ferrari, 2013; Iste, 2007; Monereo, 2005; Riel et al., 2012). Through this skill, 
we intend to deal with the information overload that occurs in the digital environment. There is so much information that it is difficult to discern what is important and what is not. As such, we can have problems understanding an issue or making decisions. Therefore, users should have the competence to find, select, analyse, compare, contrast, understand, summarise, and retrieve information. This is a very important skill since we use information in daily life.

4. Critical skill: ability to critically analyse the information obtained. Thus, the user is able, for example, to discover the truth or falsity of the information contained in an email. Through this skill, the individual also knows how to identify and avoid harmful content and contacts (Area Moreira \& Pessoa, 2012; Cabero Almenara et al., 2012; Ferrés \& Piscitelli, 2012; Ktoridou et al., 2012). Finally, the user reflects on the veracity and validity of the information that they are receiving.

5. Security skill: ability to use interactive communication without risks and danger. This skill includes, for example, knowing how to manage a digital reputation or how to protect the privacy of personal information that is available online. In this sense, sometimes young users do not realise that their social media profile is public and can put a large amount of personal information online. This information can be accessible to many users, among which can be found predators, paedophiles, or malicious people in general. For this reason, is important that minors know how to control the privacy of their information and what kind of information they can put online. Moreover, this skill also includes individuals understanding the impact of their actions, such as impersonation or illegal downloading of content. Finally, it also includes knowing and using protective software, such as antivirus packages (Cabero Almenara et al., 2012; Ferrari, 2013; Ferrari, Punie, 
\& Redecker, 2012; Iste, 2007; Riel et al., 2012). Therefore, this skill refers to the safe, legal and responsible use of digital technology.

In Table 8 we present a summary of our conceptual model of digital literacy with five digital skills.

Table 8.

Conceptual model of digital literacy for the present study

\begin{tabular}{ll}
\hline Digital skills & Definition \\
\hline Technological & Ability to effectively use digital technologies \\
Communication & Ability to communicate through digital technologies \\
Anformation & $\begin{array}{l}\text { Ability to find information, obtain it, and evaluate its relevance in the } \\
\text { digital environment. }\end{array}$ \\
Critical & Ability to critically analyse the information obtained \\
Security & Ability to use digital technology without risks and dangers \\
\hline
\end{tabular}

\subsection{Digital Literacy Measures}

In order to study people's digital skills, researchers have started to develop digital literacy measures. Nonetheless, although many studies have defined and conceptualised digital literacy, there is a lack of research on developing measures of such literacy (Lau \& Yuen, 2014; Siddiq, Hatlevik, Olsen, Throndsen, \& Scherer, 2016; van Deursen, Helsper, \& Eynon, 2014). In fact, it has been claimed that "more theoretically informed, reliable and valid instruments that are able to measure developments in this area" are needed (van Deursen, Helsper, \& Eynon, 2015, p. 37).

Previous literature presents different procedures for the assessment of digital literacy (Siddiq et al., 2016). According to van Deursen et al. (2014), we can find three types of procedures: (a) surveys that measure the frequency of use of digital devices or applications, which are supposed to give indirect evidence for the command of a skill; (b) surveys that measure self-reported skills through self-assessment by the 
participant; and (c) performance tests in which participants complete certain assignments.

Self-reported questionnaires are the most frequently used method for measuring digital skills and, as such, digital literacy (Kuhlemeier \& Hemker, 2007; van Deursen et al., 2014). Nonetheless, some researchers consider that digital skills should be directly observed in performance tests (Sonck \& de Haan, 2013). However, the cost and time consuming nature of such tests are strong limitations for large scale population-wide surveys (van Deursen et al., 2014; van Deursen, van Dijk, \& Peters, 2012). Therefore, self-report questionnaires are unquestionably most useful for measuring digital skills when dealing with large samples in a short time.

As we said before, there is a lack of research on developing measures of digital literacy. Furthermore, some of the currently existing measures have several limitations, such as not being up to date with the rapid changes in technology (van Deursen et al., 2014; Wilson et al., 2015), having a narrow focus on the Internet with the omission of other technological developments (Hargittai \& Hsieh, 2012; S.-J. Lee \& Chae, 2012; Len-Ríos, Hughes, McKee, \& Young, 2016; M.-J. Tsai \& Tsai, 2010) or not having been validated (Bulger, Mayer, \& Metzger, 2014; Gastelú, Kiss, \& Domínguez, 2015; Lazzari, 2016; Li \& Ranieri, 2010; S. Park \& Burford, 2013; Pérez-Escoda, CastroZubizarreta, \& Fandos-Igado, 2016; Pino Juste \& Soto Carballo, 2010).

Added to that, some of the measures have been validated only among children, adults or young adults (Boyaci \& Atalay, 2016; Bunz et al., 2007; Helsper \& Eynon, 2013; Koc \& Barut, 2016; S. Park \& Burford, 2013; Røkenes \& Krumsvik, 2016; van Deursen et al., 2014), but not specifically among adolescents, which is our target population. Consequently, in Table 9 we present a review of digital literacy measures developed for adolescents.

As we can see, most of the measurements do not include items related to security or digital safety (E. mee Kim \& Yang, 2016; Kuhlemeier \& Hemker, 2007; Lau 
\& Yuen, 2014). Moreover, the scales developed by Kuhlemeier and Hemker (2007) and Kim and Jang (2016) only contain items related to technological and informational knowledge and omit other digital skills. Additionally, Kuhlemeier and Hemker's (2007) study focuses only on Internet skills for schools and does not include validating analyses. Finally, in the scale of digital literacy in the EU Kids Online study (Sonck et al., 2011), only eight items were used for measuring three different skills. However, results from an exploratory factor analysis showed that there was only one single factor in the scale of digital skills. In this sense, the Net Children Go Mobile study (Mascheroni \& Ólafsson, 2014) uses that same scale with five new items designed to measure communication skill. However, they do not report any validating analysis of the scale.

As we have seen, research on developing measures of digital literacy is scarce, especially in the case of adolescents. Therefore, further research is necessary to develop reliable and valid measures of digital literacy and digital skills. In particular, we consider that more research is needed to develop and validate a scale that measures the five digital skills that we proposed previously. 
RISKS OF INTERACTIVE COMMUNICATION IN ADOLESCENTS.

DIGITAL LITERACY DIAGNOSIS AND INTERVENTION

Table 9.

Digital literacy measures developed and validated among adolescents

\begin{tabular}{|c|c|c|c|c|}
\hline Study & Sample & Measurement & Analyses & Dimensions \\
\hline $\begin{array}{l}\text { (E. mee Kim \& } \\
\text { Yang, 2016) }\end{array}$ & $\begin{array}{l}257 \text { students in } 10^{\text {th }} \\
\text { grade }\end{array}$ & $\begin{array}{l}\text { Internet literacy: Self- } \\
\text { reported test with ten } \\
\text { items }\end{array}$ & $\begin{array}{l}\text { Cronbach's alpha and } \\
\text { exploratory factor } \\
\text { analysis }\end{array}$ & $\begin{array}{l}\text { (1) Internet skill literacy } \\
\text { (2) Internet information literacy }\end{array}$ \\
\hline \multirow{4}{*}{$\begin{array}{l}\text { (Kuhlemeier \& } \\
\text { Hemker, 2007) }\end{array}$} & \multirow{4}{*}{$\begin{array}{l}2,615 \text { students } \\
\text { (13-15 years old) in } \\
\text { secondary } \\
\text { education }\end{array}$} & \multirow{4}{*}{$\begin{array}{l}\text { Internet skills for school: } \\
\text { performance test with } 36 \\
\text { items. }\end{array}$} & \multirow{4}{*}{$\begin{array}{l}\text { Item response theory } \\
\text { analysis }\end{array}$} & $\begin{array}{l}\text { (1) Know how to use the Internet } \\
\text { to search for relevant } \\
\text { information }\end{array}$ \\
\hline & & & & $\begin{array}{l}\text { (2) Be able to communicate with } \\
\text { others via e-mail }\end{array}$ \\
\hline & & & & $\begin{array}{l}\text { (3) Be familiar with current } \\
\text { Internet terminology }\end{array}$ \\
\hline & & & & $\begin{array}{l}\text { (4) Have a command of some } \\
\text { general windows principles and } \\
\text { word processing skills }\end{array}$ \\
\hline (Lau \& Yuen, 2014) & $\begin{array}{l}826 \text { students in } 8^{\text {th }} \\
\text { grade }\end{array}$ & $\begin{array}{l}\text { Perceived ICT literacy } \\
\text { scale: self-reported test } \\
\text { with } 17 \text { items }\end{array}$ & $\begin{array}{l}\text { Cronbach's alpha, } \\
\text { exploratory factor } \\
\text { analysis and second- } \\
\text { order confirmatory } \\
\text { analysis. }\end{array}$ & $\begin{array}{l}\text { (1) Information literacy } \\
\text { (2) Internet literacy } \\
\text { (3) Computer literacy }\end{array}$ \\
\hline
\end{tabular}


CHAPTER 2. DIGITAL LITERACY AND DIGITAL SKILLS

\begin{tabular}{|c|c|c|c|c|}
\hline Study & Sample & Measurement & Analyses & Dimensions \\
\hline $\begin{array}{l}\text { (Mascheroni \& } \\
\text { Ólafsson, 2014) }\end{array}$ & $\begin{array}{l}3,500 \text { (9-16 years } \\
\text { old) Internet users }\end{array}$ & $\begin{array}{l}\text { Net Children Go Mobile: } \\
\text { Self-reported test with } 13 \\
\text { items }\end{array}$ & - & $\begin{array}{l}\text { (1) Instrumental } \\
\text { (2) Critical } \\
\text { (3) Safety } \\
\text { (4) Communication }\end{array}$ \\
\hline (Sonck et al., 2011) & $\begin{array}{l}25.000 \text { (9-16 years } \\
\text { old) Internet users }\end{array}$ & $\begin{array}{l}\text { EU Kids Online: Self- } \\
\text { reported test with eight } \\
\text { items }\end{array}$ & $\begin{array}{l}\text { Cronbach's alpha and } \\
\text { exploratory factor } \\
\text { analysis }\end{array}$ & (1) Digital literacy \\
\hline
\end{tabular}




\subsection{Summary and Conclusions}

In this chapter we have presented a review of the literature on digital literacy and digital skills. First, we have looked at the antecedents and the definition of the term digital literacy. As we have seen, this concept has been developed after other literacies. Consequently, we have also discussed these literacies: information literacy, media literacy, news media literacy and multiliteracy. We have discovered that these concepts share conceptual grounds and that, in fact, digital literacy relies on some of them. We have then reviewed the different definitions of digital literacy, as there is no agreement on a common definition.

Secondly, we have analysed the different digital skills that make up the broader concept of digital literacy. As with the definition, there is no commonly accepted model. Therefore, we have revised previous models and have proposed a model of digital literacy for adolescents with five digital skills: technological, communication, information, critical, security.

Finally, we have analysed the digital literacy measures that have been developed so far. There is a lack of research on this area and some of the currently existing measures have several limitations, such as being obsolete or not having been validated. Moreover, the present study focuses on adolescents, but validated measures among this population are very scarce. Therefore, we have called for more research that develops and validates measurements of digital literacy.

At any rate, as we mentioned at the beginning, digital literacy and digital skills have been pointed out as essential in a range of professional occupations, for different aspects of people's lives and for being successful in our society. In the case of children and adolescents, some research has suggested that digital literacy could be a prevention tool against online risks and a facilitator of online opportunities. In the next chapter we will analyse the different types of online risks and online opportunities and the impact that digital skills have on them. 


\section{Chapter 3.}

\section{ONLINE RISKS AND}

\section{ONLINE OPPORTUNITIES}

\footnotetext{
7 ears about the negative consequences that exposure to media can have on 1 minors are of long standing (Valkenburg \& Piotrowski, 2017). Throughout history, parents, educators and researchers have been concerned about the
} negative effects that new media, such as comics (e.g., Blakely, 1958; Brand, 1969), cinema and television (e.g., Blumer, 1933; Liebert, 1986; Maccoby, 1951), or videogames (e.g., Cooper \& Mackie, 1986; Schutte, Malouff, Post-Gorden, \& Rodasta, 1988), could have on children and adolescents. Thus, these media were blamed for causing negative effects on minors.

With the emergence of digital media, parents started to have worries and concerns about the actions and experiences their children have online (Lazarinis, 2010; Sorbring, 2014). However, even though information and communication technology is associated with potentially dangerous risks, it also offers opportunities for learning and entertainment that adolescents can take advantage of. Consequently, when analysing the negative effects of ICT, it is essential not to forget the positive ones.

In view of the above, the purpose of this chapter is to review the different types of online risk behaviours, their frequencies and their consequences for adolescents. Moreover, we will also refer to the opportunities that digital technology 
RISKS OF INTERACTIVE COMMUNICATION IN ADOLESCENTS.

DIGITAL LITERACY DIAGNOSIS AND INTERVENTION

offers to this sector of the population. Finally, we will discuss the role of digital skills as a prevention tool against online risks and as a facilitator for online opportunities.

\subsection{Online Risk Behaviours and their Consequences}

Even though adolescents are technology sophisticated users and they are usually at the forefront of information and communication technology and of the use of new digital devices, their technological knowledge can lead them to be involved in risky online behaviours (Agatston et al., 2007). Consequently, and given their extensive use of digital technologies, young people are likely to be exposed to numerous online threats (Ktoridou et al., 2012). According to scholars, these online risk behaviours include contact with strangers, engagement in sexting, exposure to online pornography, exposure to online violence and cyberbullying (Agatston et al., 2007; Catalina García et al., 2014; Dowdell et al., 2009; Livingstone \& Helsper, 2010; Livingstone \& Smith, 2014; Staksrud et al., 2013; Vandoninck et al., 2013).

These terms are conceptualised as risks because they are associated with a certain likelihood and magnitude of harm. That is, they carry the chance that minors might have a negative experience (Livingstone, 2013; Sonck \& de Haan, 2013). However, not all minors that are exposed to these risks will suffer such harm, since exposure to online risks does not necessarily mean harm. It only indicates the probability of experiencing harm (Livingstone, 2017; Staksrud et al., 2013). In this way, some minors can be more vulnerable and suffer the negative consequences of online risks (Vandoninck, 2016). Therefore, these online risk behaviours can have serious psychological consequences for some adolescents, such as causing anxiety or depression.

In what follows, we will describe each of the five online risks mentioned above. For each of them we will see its characteristics, its frequency in adolescents, its 
potential negative outcomes and the different solutions proposed by scholars for facing it.

\subsubsection{Contact with strangers}

When using interactive communication, adolescents can communicate with people they do not know face to face. The misuse of personal information and the stranger danger that may arise from this contact have been of concern to parents, educators, media and regulators (Barbovschi, Marinescu, Velicu, \& Laszlo, 2012; Kupiainen, Suoninen, \& Nikunen, 2012). Thus, public profiles on social media sites or open sharing of information with strangers can lead to misuse of personal information (Kupiainen et al., 2012).

According to previous research, a quarter of adolescents (12-17 years old) have provided personal information to strangers over the net (Catalina García et al., 2014) and between 1 and $3 \%$ of minors (11-15 years old) have posted their phone number or their home address (Dowdell et al., 2009). Moreover, the EU Kids Online study found that $30 \%$ of children (9-16 years old) have made contact online with a stranger and $9 \%$ have met an online contact offline (Livingstone, Haddon, Görzig, et al., 2011a). Likewise, other studies with minors (9-15 years old) have concluded that $13.6 \%$ of participants had communicated with someone known only to them from the Internet and $8 \%$ of them had met an online stranger in person (Dowdell, 2011). In line with these results, a study with youths aged 12-17 (Liau, Khoo, \& Hwaang, 2005) found that $16 \%$ of minors had met someone in real life that they first encountered online.

Although prevalence varies between studies, we can establish that between two and three in ten adolescents have contacted a stranger online, and one in ten have met this person offline. In this sense, a study with adolescents aged 10-17 found that $16.3 \%$ of participants had had real life encounters with online contacts, and in $3 \%$ of these encounters, the other person had lied about their identity (van den Heuvel, van den Eijnden, van Rooij, \& van de Mheen, 2012). 
Consequently, the risk arising from online contact with strangers is that this experience can be negative for minors and a threat to their online safety (Heirman et al., 2015). Users who share personal information are vulnerable to stalking, sexual grooming and cyberbullying (Kupiainen et al., 2012). In fact, some adolescents have reported negative experiences when communicating with strangers online, such as receiving insults or unwanted sexual content (Cernikova et al., 2018). Moreover, in some cases, contact with unknown people can lead to online sexual grooming, whereby an adult, with sexual intentions, contacts a minor, lies about their identity and gains their confidence (Gámez-Guadix, Almendros, Calvete, \& De Santisteban, 2018) with the final objective of meeting the minor (Valcke, De Wever, Van Keer, \& Schellens, 2011). In a study conducted with Spanish adolescents (12-15 years old), 8\% of participants reported having been involved in online grooming (Gámez-Guadix et al., 2018). Moreover, in another study with American students (9-15 years old), $10 \%$ of participants that had met an online stranger in person, reported being sexually assaulted or inappropriately touched as a result of their offline meeting (Dowdell, 2011). Related to this, it has been demonstrated that there exists a relationship between suffering sexual harassment on the Internet and suffering eating disorders such as anorexia (Gati, Tényi, Túry, \& Wildmann, 2002).

Notwithstanding this, children and adolescents report both positive and negative experiences when interacting with online strangers. In fact, the majority of interactions are harmless and they can have potential benefits (Barbovschi et al., 2012; Cernikova et al., 2018). It is natural that youth want to meet new friends, and they can also do it online (Cernikova et al., 2018). Moreover, when contacting online strangers, adolescents are motivated by different reasons, such as looking for entertainment, being curious about meeting people or being inhibited in face to face conversations (Peter, Valkenburg, \& Schouten, 2006). Online contact with strangers can be a risky behaviour, but it also has benefits and can be an opportunity to meet new people. Through interactive communication, adolescents are expanding their social circles 
(Barbovschi et al., 2012) and exploring their identities (Peter et al., 2006). Furthermore, when communicating with strangers online, adolescents "can express ideas or concerns that they cannot disclose to people whom they know off-line" (Heirman et al., 2015, p. 1128).

At any rate, there is a risk of danger when contacting online strangers that makes prevention education and digital literacy necessary (Cernikova et al., 2018; Gámez-Guadix et al., 2018). Consequently, adolescents should learn how to protect their personal information online (Dowdell, 2011). This, therefore, along with learning how to protect their personal information online and how to contact strangers safely online, without risking their physical and mental integrity, are key aspects of online safety.

\subsubsection{Sexting}

Sexting refers to sending and receiving sexually explicit texts, images or videos. These messages, pictures or videos are self-produced and can be sent via Internet or mobile phone (Garmendia \& Karrera, 2018). Therefore, it is a form of sexual expression that uses digital technology and that allows adolescents to explore their relationships and their sexuality (Döring, 2014). In this context, sexting can be a way of flirting or expressing sexuality in romantic relationships (Garmendia \& Karrera, 2018; van Ouytsel, van Gool, Walrave, Ponnet, \& Peeters, 2017; Ybarra \& Mitchell, 2014). In fact, a strong predictor of sexting is being in a romantic relationship (Delevi \& Weisskirch, 2013; Döring, 2014).

The study EU Kids Online notes that $15 \%$ of European children (9-16 years old) have been involved in a sexting activity (Livingstone, Haddon, Görzig, et al., 2011a). Similarly, in a study with American adolescents (12-18 years old), 15\% of participants reported having sent a sexually explicit message or photo of themselves by phone (Rice et al., 2012). More enlightening, a systematic literature review concluded that $10 \%$ of adolescents (10-19 years of age) send sexts containing sexually 
explicit text or pictures (Klettke, Hallford, \& Mellor, 2014). That is, at least one in ten adolescents have been involved in a sexting activity.

Regarding the negative consequences, sexting has been positively related to sexual activity (Brinkley, Ackerman, Ehrenreich, \& Underwood, 2017; Houck et al., 2014; Klettke et al., 2014; Kosenko, Luurs, \& Binder, 2017; Rice et al., 2012; Ybarra \& Mitchell, 2014) and risky sexual behaviours (Klettke et al., 2014; van Ouytsel, Walrave, Ponnet, \& Heirman, 2015; Ybarra \& Mitchell, 2014), such as having unprotected sex. However, research on this topic usually uses a cross-sectional design. Therefore, it does not allow establishment of causation. It could be that sexting is the consequence of, and not the antecedent of, risky sexual behaviour (Crimmins \& Seigfried-Spellar, 2014; Kosenko et al., 2017; van Ouytsel et al., 2015).

The exchange of sexually explicit material is not a new phenomenon. However, digital technologies have facilitated its creation and distribution (Rice et al., 2012). Therefore, one of the biggest problems arising from sexting is that sexually explicit material can be easily, quickly and widely shared online and the creator will not have control over it. This content could end up on mobile phones, social networks or websites without the consent of the creator. In consequence, personal content or a message sent privately can easily be shared with others. Consequently, the unwanted dissemination of private texts, pictures or videos is very difficult to control.

Many adolescents are involved in sexting with little regard for the possible psychological, interpersonal or legal consequences of doing so (Strassberg, McKinnon, Sustaíta, \& Rullo, 2013). Nonetheless, the viral and non-consensual spread of sexual images has psychological consequences for the victims, but also social and legal consequences (Katzman, 2010). Sometimes, the adolescent who sent their sexually explicit text, image or video ends up being a victim of cyberbullying (Garmendia \& Karrera, 2018; Reyns, Burek, Henson, \& Fisher, 2013). Jokes, insults and rejection may have severe psychological effects. In fact, in some cases the humiliation and bullying 
lead the victim to suicide (Chalfen, 2009). This situation is worse for girls as their engagement in sexting is more stigmatised than is the case for boys (van Oosten \& Vandenbosch, 2017).

At any rate, it is important to note that sexually explicit pictures or videos containing minors is considered to be illegal as it is considered a form of child pornography (Klettke et al., 2014). Thus, the distribution and possession of pornographic or erotic photographs of children is a crime in many countries and many adolescents could be committing a crime without knowing it.

In view of the above, sexting is a form of sexual communication that can have both positive and negative outcomes for the participants. It can be private, but also public, trivial or significant, and pleasurable or hurtful (Livingstone \& Görzig, 2012). Nonetheless, as minors may be more vulnerable to the possible negative outcomes of sexting, it is important to educate them in the proper use of digital technology (Gámez-Guadix, de Santisteban, \& Resett, 2017). These educational initiatives could provide adolescents with information about the potential consequences, such as the possibility of unintended distribution of the sexual content (Klettke et al., 2014; Ybarra \& Mitchell, 2014). Moreover, interventions should also address the influence of peer social norms, as it has been seen that peer influence is relevant when participating in sexting (Döring, 2014; van Ouytsel, Ponnet, Walrave, \& D'Haenens, 2017; Vanden Abeele, Campbell, Eggermont, \& Roe, 2014). At any rate, sexual curiosity and exploration during adolescence is natural. Therefore, "a turn from the dominant educational recommendation of sexting abstinence to safer sexting education should be considered" (Döring, 2014).

\subsubsection{Exposure to pornography}

Exposure to online pornography or exposure to sexually explicit online material refers to the consumption of sexual content via online and digital media. This content can be pictures or videos, which "are intended to sexually arouse the viewer", and they

$$
\sim 61 \sim
$$


"typically depict sexual activities, such as masturbation and oral sex, as well as vaginal and anal penetration, in an unconcealed way, often with a close-up on genitals" (Peter \& Valkenburg, 2016, p. 510). Moreover, their consumption may be deliberate or accidental, as adolescents may seek sexually explicit content online or may be exposed to this accidentally or involuntarily (e.g., pornographic pop-up ads; Flood, 2009). The easy accessibility to this type of content has raised concerns about the negative effects of its consumption among adolescents (Koletić, 2017).

On the one hand, and regarding unintentional exposure, one of the first studies on this topic found that $25 \%$ of adolescents (10-17 years old) who used the Internet had regularly had unwanted exposure to sexual content while online (Mitchell, Finkelhor, \& Wolak, 2003). However, rates seem to have increased lately (Peter \& Valkenburg, 2016), since it has been found that seven out of ten young people (15-18 years old) have unintentionally been exposed to pornography (Hardy, Steelman, Coyne, \& Ridge, 2013).

On the other hand, and regarding intentional exposure to online pornography, it has been found that six out of ten adolescents regularly consume online pornography (Vandoninck et al., 2010). Similarly, another study showed that eight out of ten male adolescents and two out of ten female adolescents have been exposure to online pornography on purpose before the age of 18 (Sabina, Wolak, \& Finkelhor, 2008). Likewise, $60 \%$ of male and $20 \%$ of female adolescents have looked for online sexual content in the past half year (Valkenburg \& Piotrowski, 2017). The prevalence of online pornography consumption varies between studies, but results suggest that "at least a sizable minority of all adolescents use pornography" (Peter \& Valkenburg, 2016, p. 515). This deliberate consumption of pornography is a maledominated practice (Beyens, Vandenbosch, \& Eggermont, 2015; J. D. Brown \& L'Engle, 2009; Flood, 2009; Livingstone, Haddon, Görzig, et al., 2011a; Peter \& Valkenburg, 2016; Vanden Abeele et al., 2014). Moreover, previous research has shown that, as with 
sexting, online pornography use is related to peer pressure and peer acceptance (Vanden Abeele et al., 2014) and is predicted by pubertal status, sensation seeking and sexual interest (Beyens et al., 2015; Koletić, 2017; Peter \& Valkenburg, 2016).

In general, exposure to pornography is related to more liberal and permissive sexual attitudes, sexist notions of women as sexual objects and unhealthy notions of sex. Moreover, exposure to sexually violent material is related to sexually aggressive attitudes (Bonino, Ciairano, Rabaglietti, \& Cattelino, 2006; J. D. Brown \& L'Engle, 2009; Flood, 2009; Peter \& Valkenburg, 2016). Specifically, exposure to sexually explicit online material is related to outcomes that are potentially harmful for adolescents' sexual development, such as the endorsement of recreational and permissive attitudes toward sex, willingness to engage in casual sex, early sexual initiation, notions of women as sex objects, stimulation of sexual preoccupancy and reduction of sexual satisfaction (Baams et al., 2015; Koletić, 2017; Peter \& Valkenburg, 2006, 2007, 2008, 2009, 2010; van Oosten, Peter, \& Vandenbosch, 2017; Vandenbosch \& Eggermont, 2013; Vandenbosch \& van Oosten, 2018). Therefore, sexually explicit online content is acting as a sexual socialisation agent and influencing adolescents' beliefs and ideas about sex (Vandenbosch \& Eggermont, 2013). Furthermore, this consumption can decrease boys' school performance (Beyens et al., 2015).

It is important to note that exposure to online pornography may be inherent to normal adolescent development, as exploration and curiosity about sexuality is part of the adolescence and is related to the dynamics of adolescent peer groups (Beyens et al., 2015; J. D. Brown \& L'Engle, 2009; Rovolis \& Tsaliki, 2012; Vanden Abeele et al., 2014; Vandenbosch \& van Oosten, 2018). Research on positive outcomes of adolescents' consumption of pornography is practically non-existent, but it could be related to aspects such as sexual pleasure or sexual knowledge (Peter \& Valkenburg, 2016). 
RISKS OF INTERACTIVE COMMUNICATION IN ADOLESCENTS.

DIGITAL LITERACY DIAGNOSIS AND INTERVENTION

Nevertheless, and due to the negative consequences that such consumption may have on adolescents, educational efforts must be made to mitigate these effects. Adolescents are in a critical period as sexual processes are fundamental in adolescent development (Vandenbosch \& Eggermont, 2013), but pornography seems to be a poor sex educator (Flood, 2009). Therefore, instead of prohibiting young people from the consumption of online pornography, it seems more adequate to educate them about such content (Peter \& Valkenburg, 2010). Accordingly, some scholars have proposed that media literacy should be promoted among this population to help them to critically evaluate this content (Flood, 2009; Shek \& Ma, 2012; Štulhofer, Buško, \& Landripet, 2010).

\subsubsection{Exposure to violence}

This type of online risk refers to adolescents' exposure to violent or shocking content online, such as hate speech content, gruesome and gory images, pictures or videos of auto-mutilation and dead or dying people, among others, on websites, social media sites and interactive communication applications. Concerns about the negative effects of consumption of violent media content on adolescents are of long standing. In fact, media violence and its effects on aggression is the most investigated topic in the field of communication (Valkenburg \& Piotrowski, 2017). Therefore, the emergence of digital media has raised fears and led to studies about the online violent content that young people can view there and its effects.

According to previous research, four out of ten youngsters have been exposed to aggressive or violent online content (Vandoninck et al., 2010). Similarly, in another study, $41 \%$ of youths (10-15 years of age) reported that they had viewed online violent content, such as on hate web sites or web sites with pictures of dead people, in the past 12 months (Ybarra et al., 2008). Finally, in Spain nearly one quarter of adolescents (12-17 years old) have seen websites with violent content (Catalina García et al., 2014). 
Research has shown that violent media exposure is a risk factor for aggressive behaviours and aggressive thoughts (Bender, Plante, \& Gentile, 2017; Bushman \& Huesmann, 2006; Krahé, 2014; Paik \& Comstock, 1994). Moreover, exposure to media violence reduces sympathy in teens and, as a result, desensitises them (Vossen, Piotrowski, \& Valkenburg, 2017). Specifically, exposure to online violence is a significant predictor of violent behaviour, along with other risk factors such as substance use or having delinquent peers (Ybarra et al., 2008). However, this is a controversial topic and other researchers argue that there is no evidence from existing literature for the relationship between violent media content and aggressive behaviour (Ferguson \& Kilburn, 2009).

It is important to note that "not all media violence leads to aggressive behaviour" (Valkenburg \& Piotrowski, 2017, p. 114). The effects of its consumption are moderated by individual characteristics, such as aggressive tendencies (J. D. Brown \& Bobkowski, 2011), and social context variables, such as perceived peer norms (Fikkers, Piotrowski, Lugtig, \& Valkenburg, 2016). In fact, violent media use can be predicted by individual characteristics ( e.g., "teenagers high in sensation seeking are predisposed to use violent media, which in turn will stimulate their aggressive behaviour"; Valkenburg \& Peter, 2013, p. 223).

At any rate, media literacy has been proposed as a promising strategy for mitigating some of the potentially harmful effects of adolescents' exposure to violent content on media, such as television or videogames (J. D. Brown \& Bobkowski, 2011; Fingar \& Jolls, 2014; Webb, Martin, Afifi, \& Kraus, 2010). However, until now there have been no studies about the effectiveness of digital literacy in the face of violent online content.

\subsubsection{Cyberbullying}

Cyberbullying is a form of bullying in which forms of interactive communication, such as instant messaging or social media platforms, are used to intimidate, harass, 
embarrass, threaten, humiliate or, in general, harm an individual or a group (Mason, 2008; Patchin \& Hinduja, 2010b). This harassment mainly involves juveniles or students and can occur through insults, threats or false accusations, among others (Cohen-Almagor, 2018).

The main difference between traditional bullying and cyberbullying is that the latter can occur at any time and in any place. Therefore, it can happen 24 hours a day and 7 days a week. Thus, in part, cyberbullying has been facilitated by adolescents' practically unlimited access to the Internet and social media sites (Ang, 2015; Festl \& Quandt, 2016). Furthermore, in cyberbullying the harasser can be hidden under an apparent anonymity, although the harassment is public. Therefore, bullies experience a disinhibition effect and have sense of a impunity, little to no fear of punishment and feeling of invisibility (Arnaiz, Cerezo, Giménez, \& Maquilón, 2016; Chisholm, 2006; Watts, Wagner, Velasquez, \& Behrens, 2017), which "can make victims feel powerless, relative to their perpetrator" (Kowalski, Limber, \& McCord, 2018, p. 2). Moreover, with the use of digital technologies, hurtful messages, insults or photos are easily and quickly disseminated, can be difficult to remove from the Internet and are often visible to a large online audience (Cohen-Almagor, 2018; Cross et al., 2016). Consequently, a single act of aggression can be perceived as repeated (e.g., a photo shared on a social media site can be seen many times and by many people; Del Rey, Estévez, \& Ojeda, 2018).

Estimates of the prevalence of cyberbullying vary between studies from $5 \%$ to $34 \%$ of minors (Cohen-Almagor, 2018). This prevalence is predicted to increase over the next few years (Brewer \& Kerslake, 2015; Tomczyk, 2017). According to the EU Kids Online study, $6 \%$ of European children (9-16 years old) have received nasty or hurtful messages online (Livingstone, Haddon, Görzig, et al., 2011a). Another study with English students aged $16-18$ years, showed that $16.2 \%$ and $13.5 \%$ of participants have been victims and perpetrators of cyberbullying respectively (Brewer \& Kerslake, 2015). 
Likewise, it has been found that $14.6 \%$ of Korean adolescents (7th-12th grades) have been involved in cyberbullying as victims, $6.3 \%$ as bullies and $13.1 \%$ as both bullies and victims (C. Lee \& Shin, 2017). Similarly, 23\% of Dutch students from primary and secondary schools reported having been victims of cyberbullying (Dehue, Bolman, \& Völlink, 2008). In addition, one tenth of adolescents aged 12-17 have had their identity supplanted in a harmful way (Catalina García et al., 2014).

According to Del Rey et al. (2018), cyberbullying can affect both the bullied and the bullies and its consequences are similar to those of traditional bullying. Thus, many studies have shown the existence of a link between suffering cyberbullying and suffering anxiety, depression, stress, fear, sleep disturbance, loss of appetite, headaches, feelings of anger, sadness, rejection and frustration, irritability, suicidal ideation, suicide attempts and even suicide itself (Dehue et al., 2008; Del Rey et al., 2018; Garaigordobil, 2011; Giménez Gualdo, Hunter, Durkin, Arnaiz, \& Maquilón, 2015; Hinduja \& Patchin, 2010; Lonigro et al., 2014; Messias, Kindrick, \& Castro, 2014; Schneider, O'Donnell, Stueve, \& Coulter, 2012). On the other hand, bullies are more likely to show lack of empathy, to suffer from depression, to show aggressive and criminal behaviour and to report higher use of alcohol and drugs (Cohen-Almagor, 2018; Garaigordobil, 2011; Nixon, 2014).

Adolescents are particularly vulnerable to cyberbullying because they are not fully capable of completely understanding the consequences of their behaviour (Ang, 2015). Moreover, they are emotionally unstable, lack ability to make reasonable decisions and are susceptible to peer pressure. They tend to give more importance to short term benefits and underestimate long term risks. Thus, bullies tend to be motivated by emotions more than reasoning, and the bullied are not able to rationalise their predicament (Cohen-Almagor, 2018).

Consequently, cyberbullying is becoming a highly concerning problem and responsive educational interventions should be implemented in schools (Calvete, 
Orue, Estévez, Villardón, \& Padilla, 2010; Hinduja \& Patchin, 2010). According to some scholars, these interventions should promote empathy, interpersonal peer relationships, emotional development and ways to address peer pressure (Ang, 2015; Calvete et al., 2010; Cohen-Almagor, 2018).

In this section we have reviewed the five types of online risk behaviours, their frequency and their consequences for adolescents. As we have seen, rates of frequency vary between studies, but in general online risk behaviours are quite common among young people. To establish a comparison between the prevalence of online risks, in Figure 9 we present data from two studies that have addressed all of the online risk behaviours in European children aged 9-16 (Livingstone, Haddon, \& Görzig, 2011; Mascheroni \& Ólafsson, 2014). As we can see, contact with strangers is the most prevalent risky online behaviour, followed by exposure to violence.

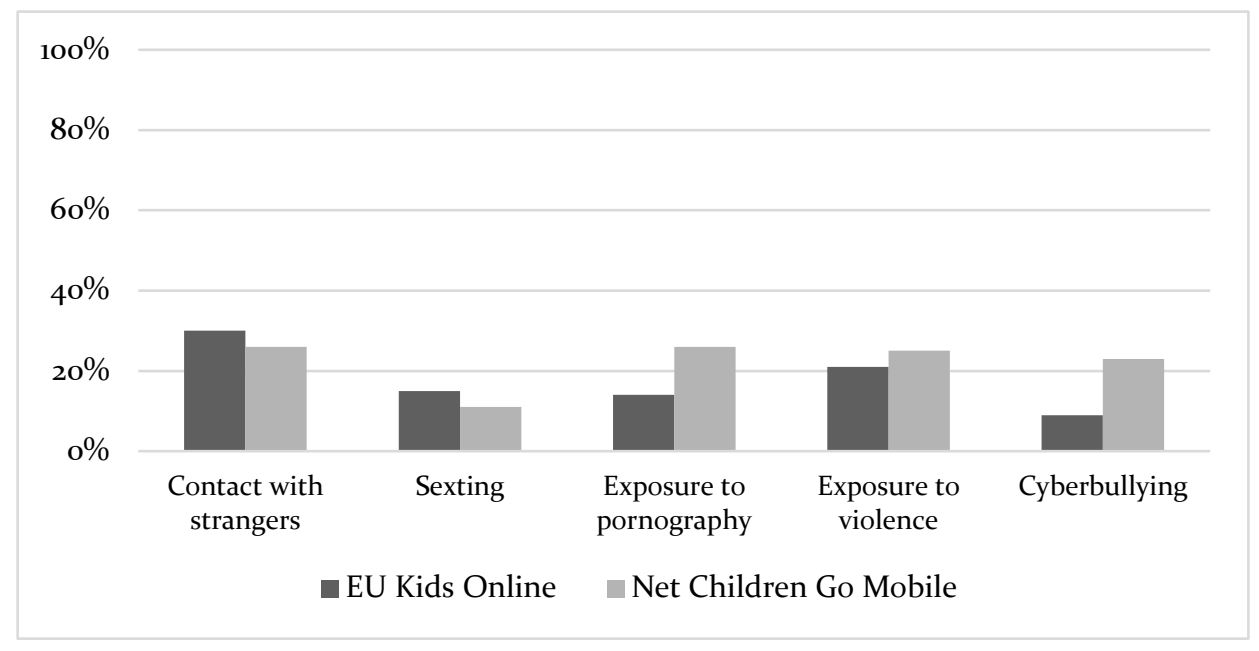

Figure 9. Prevalence of online risk behaviours among European adolescents.

Adapted from Livingstone, Haddon, and Görzig (2011), and Mascheroni and Ólafsson (2014) 
Moreover, as we have seen in this chapter, negative consequences may also vary between online risks. Therefore, in Table 10 we present a review of the negative consequences that these risks could have on young people.

Table 10.

Online risk behaviours and their possible negative outcomes

\begin{tabular}{ll}
\hline Online Risk Behaviour & Negative consequences \\
\hline Contact with strangers & Suffering online sexual grooming and cyberbullying \\
Sexting & $\begin{array}{l}\text { Engaging in sexually risky behaviours and suffering } \\
\text { cyberbullying }\end{array}$ \\
& $\begin{array}{l}\text { Having recreational and permissive attitudes toward sex, } \\
\text { willingness to engage in casual sex, early sexual initiation, }\end{array}$ \\
Exposure to pornography & $\begin{array}{l}\text { notions of women as sex objects, stimulation of sexual } \\
\text { preoccupancy and reduction of sexual satisfaction }\end{array}$ \\
& $\begin{array}{l}\text { Developing an aggressive and violent behaviour } \\
\text { Exposure to violence }\end{array}$ \\
& $\begin{array}{l}\text { Suffering anxiety, depression, stress, fear, sleep disturbance, } \\
\text { loss of appetite, headaches, feelings of anger, sad, rejection } \\
\text { and frustration, irritability, suicidal ideation, suicide } \\
\text { attempts and committing suicide }\end{array}$ \\
\hline
\end{tabular}

Note. Author's elaboration from Baams et al. (2015), Cernikova et al.(2018), Dehue et al. (2008), Del Rey et al. (2018), Dodwell (2011), Gámez-Guadix et al (2018), Garaigordobil (2011), Garmendia and Karrera (2018), Giménez Gualdo et al. (2015), Hinduja and Patchin (2010) Klettke et al. (2014), Koletić (2017), Kupiainen et al. (2012), Lonigro et al. (2014), Peter and Valkenburg (2006, 2007, 2008, 2009, 2010) Reyns et al. (Reyns et al., 2013), Schneider et al. (2012), van Oosten et. Al (2017), Van Ouytsel et al. (van Ouytsel et al., 2015), Vandenbosch and Eggermont, (2013), Vandenbosch and van Oosten (2018), Ybarra et al. (2008), Ybarra and Mitchell (2014).

Considering these risks and their consequences, adolescents should be encouraged to take responsibility for their own safety as much as possible (Livingstone, Haddon, \& Görzig, 2011). Therefore, the solution would be to give adolescents the tools to use digital technologies safely and these tools would be digital skills. Hence, according to some scholars, minors could avoid negative consequences of digital technologies by acquiring digital skills (Cernikova et al., 2018; Rodríguez-deDios \& Igartua, 2016; Sonck \& de Haan, 2014; Sonck et al., 2011). Later we will review the research conducted on the impact of digital skills on online risks. 
RISKS OF INTERACTIVE COMMUNICATION IN ADOLESCENTS.

DIGITAL LITERACY DIAGNOSIS AND INTERVENTION

In any case, fear of online risks may lead us to make inappropriate decisions. It is important to highlight that we cannot deprive adolescents of the use of interactive communication and digital technology. In fact, it would be an impossible task. Moreover, and considering that online risks do not always result in harm, it is important to "proceed with caution when intervening to manage the risk factors" (Livingstone \& Haddon, 2012, p. 7). Comparing online safety with road safety, of all minors who cross roads, only a small percentage of them will suffer an accident. Therefore panic, anxiety and uncertainty about online risks should not impede analysis and proportionate decision making (Livingstone \& Haddon, 2012). Finally, and as we shall see, the use of interactive communication and digital technology also has positive outcomes and benefits. Consequently, it is important not to forget that adolescents can also benefit greatly from digital opportunities (Livingstone, Lemish, et al., 2017) and thus we should try to prevent online risks from obscuring these online opportunities.

\subsection{Opportunities and Benefits of Interactive Communication}

When it comes to analysing the role of ICT and interactive communication in adolescents' lives, it is important not to focus only on the risks. Online opportunities matter too (Livingstone, Mascheroni, \& Staksrud, 2017). It is obvious that digital safety is important, but we must find an adequate balance between protection and adolescents' rights and opportunities (Livingstone, Lemish, et al., 2017; Livingstone \& Haddon, 2012). Nevertheless, this is not an easy task, since some strategies to reduce online risks may have the unintended consequence of limiting online opportunities and benefits (Garmendia, Garitaonandia, \& Casado, 2012; Livingstone \& Haddon, 2012). Consequently, digital technology use involves continuous debate around risks and opportunities (Pruulmann-Vengerfeldt \& Runnel, 2012). 
It is important to point out that the main difference between online risks and online opportunities is that online opportunities generally afford positive benefits for children and adolescents, whereas online risks are associated with a certain likelihood of harm (Livingstone, 2013). In any case, as with online risks, which do not always imply harm, online opportunities do not always imply benefit. That is, they just comprise the possibility that benefits or harm might occur.

Digital technologies offer a broad range of opportunities for entertainment, communication, information and education that adolescents can take advantage of (Chisholm, 2006; Ktoridou et al., 2012; Livingstone \& Helsper, 2010; Vandoninck et al., 2010). Thus, in this environment young people can learn about the world, express themselves, and experiment with their identities (Chisholm, 2006; Kupiainen et al., 2012).

Furthermore, online opportunities are usually related to adolescents' motives for using digital technology. Accordingly, one of the first studies on uses and gratifications with children and the Internet showed that children's motives for using the Internet were affinity with computers, seeking information, entertainment, boredom avoidance, online social interaction and offline social interaction. Offline social interaction was the least important motive, a fact which makes sense if we consider that, at the time, only $24 \%$ of families had home access to the Internet (Valkenburg \& Soeters, 2001). Subsequent studies have shown that audio-visual entertainment, searching for information, personal relationships, economic orientation, leisure, communication and learning are motives for using the Internet among teenagers (García Jiménez, López de Ayala López, \& Gaona Pisonero, 2012). Similarly, it was found that young people use social media sites, such as Facebook, due to six motives: entertainment, virtual community, maintenance of relationships, coolness, companionship and self-expression (Igartua \& Rodríguez-de-Dios, 2016). Likewise, another study found five types of motivations for using social media: searching for friends, social support, information, entertainment and convenience (Y. 
RISKS OF INTERACTIVE COMMUNICATION IN ADOLESCENTS.

DIGITAL LITERACY DIAGNOSIS AND INTERVENTION

Kim, Sohn, \& Choi, 2011). Accordingly, interactive communication and maintenance of social relations, the search for entertainment and learning are some of the reasons why adolescents make use of digital technology and social media.

Consequently, one of the opportunities that digital technology offers is communication. This communication-based opportunity refers to the use of instant messaging, of social media sites, of webcams and of chatrooms, among others (Pruulmann-Vengerfeldt \& Runnel, 2012). Therefore, digital technology provides young people with the possibility to interactively communicate on social media sites and instant messaging applications. As we have seen previously, adolescents engage in this type of communication daily and it has become a focal point in their social lives (Valkenburg \& Peter, 2011).

This communication offers a lot of possibilities and benefits for its users. For example, it keeps individuals connected in society (Lin, 2009). Thus, people who are thousands of miles away can stay in touch and interact instantaneously, something that would otherwise be unthinkable. Accordingly, it has been found that users resort to social networks because they are an efficient way to stay in touch with friends, to communicate, to express themselves and to make new friends (Colás, González, \& de Pablos, 2013). With the use of social media young people can enhance social relationships as they can share their thoughts, feelings and content there (Kupiainen et al., 2012). This brings benefits since online communication can enhance online selfdisclosure; that is, online communication about personal topics that are typically not easily disclosed, such as one's feelings, worries, and vulnerabilities, which in turn can promote adolescents' well-being (Valkenburg \& Peter, 2009) and social relationships (Koutamanis et al., 2013; Trepte et al., 2017). Likewise, research has shown that social media use can be beneficial for the development of empathic skills in adolescents (Vossen \& Valkenburg, 2016). 
Secondly, adolescents can also take-up of entertainment opportunities in the digital environment. For example, they can play games online or download games and other sorts of mobile applications. In this sense, research has shown that there is a link between playing video games or computer games and having higher self-reported problem solving skills (Adachi \& Willoughby, 2013), having better spatial skills (Murias, Kwok, Castillejo, Liu, \& Iaria, 2016) and cognitive skills (Mackey, Hill, Stone, \& Bunge, 2011), and an increasing speed and attention in mathematical calculations (Mahmoudi, Koushafar, Saribagloo, \& Pashavi, 2015). Moreover, playing online video games has been found to bolster adolescents' perceived life satisfaction (Kowert, Vogelgesang, Festl, \& Quandt, 2015). Finally, Jackson et al. (2006) concluded that lowincome children who used the Internet more had greater reading achievement.

The third type of opportunity is related to multimedia. It includes activities such as watching video clips online, downloading music and films, listening to music and using photo or video editing software. Therefore, digital technologies, such as smartphones, tablets or computers, allow adolescents to produce their own multimedia pieces and to watch videos, TV series or films online.

Finally, digital technology can also be used for learning outcomes. Thus, adolescents can take advantage of the Internet, the computer, the smartphone or interactive communication for learning purposes, such as searching for information, using word processor software or doing homework. In this sense, it is important to note that research has shown that use of digital technology for learning brings great benefits for adolescents. As we will discuss the outcomes of mobile learning on this population in chapter 5 , at this point we will only briefly review the educational benefits that technology offers. Accordingly, previous research has shown that the use of digital technology in learning increases students' motivation, achievement and performance (Chauhan, 2017; C. M. Chen, Tan, \& Lo, 2016; Hwang, Chen, Shadiev, Huang, \& Chen, 2014; Kebritchi, Hirumi, \& Bai, 2010; Sharifi, Rostami AbuSaeedi, Jafarigohar, \& Zandi, 2017; Taylor, Casto, \& Walls, 2007; Zakaria \& Khalid, 2016). 
Specifically, research has demonstrated that this use facilitates reading fluency (C. M. Chen et al., 2016), writing skills (Hwang et al., 2014) and problem-solving skills (K. E. Chang, Sung, \& Lin, 2006), among others.

In conclusion, digital technology offers a broad range of opportunities for entertainment, communication and education that can afford positive benefits for adolescents. In consequence, and as we have argued above, online opportunities are as important as online risks, and they should not be forgotten when dealing with the risks. In view of the facts, it is essential to study how online opportunities can be promoted among adolescents. Finally, considering the promising role of digital skills for facing online risks, it is crucial to analyse the impact of these skills on online opportunities.

\subsection{The Role of Digital Skills in Online Risks and Online Opportunities}

As we briefly mentioned earlier, it is assumed that adolescents can avoid negative consequences of digital technologies by acquiring digital skills (Cernikova et al., 2018; Rodríguez-de-Dios \& Igartua, 2016; Sonck \& de Haan, 2014; Sonck et al., 2011). Taking into consideration the good results obtained through media literacy in addressing the harmful effects of mass media, digital skills could be a prevention tool against online risks. Thus, positive effects of media literacy interventions have been observed across diverse agents, target age groups, settings, topics, and countries (Austin, Chen, Pinkleton, \& Johnson, 2006; Banerjee \& Greene, 2007; Bickham \& Slaby, 2012; Duran, Yousman, Walsh, \& Longshore, 2008; Fingar \& Jolls, 2014; Halliwell, Easun, \& Harcourt, 2011; Irving, Dupen, \& Berel, 1998; Jeong et al., 2012; Pinkleton, Austin, Cohen, Chen, \& Fitzgerald, 2008; Pinkleton, Austin, Cohen, Miller, \& Fitzgerald, 2007). For example, it was shown that a media literacy-based intervention had several positive effects on the responses of minors to media messages. Teens who followed 
the media literacy training were more convinced about the influence of the media on their decision making and had stronger beliefs that most portrayals in the media are fictitious (Pinkleton, Austin, Chen, \& Cohen, 2013). Similarly, media literacy interventions can reduce body dissatisfaction caused by attention to media appearance ideals (McLean, Paxton, \& Wertheim, 2016).

Accordingly, digital literacy interventions are expected to be effective in addressing the harmful effects of digital media. So, the more digitally literate adolescents are, the more benefits they could get from the digital environment. In addition, they would also know better how to face online risks (Sonck et al., 2011). However, there are very few empirical studies that examine the relationship between digital skills and online risks (Sonck \& de Haan, 2014) and, contrary to what is expected, initial evidence suggests that the more skilled adolescents are, the more online risks they experience (S.-J. Lee \& Chae, 2012; Leung \& Lee, 2012b; Livingstone, Ólafsson, et al., 2017; Livingstone \& Helsper, 2010; Sonck \& de Haan, 2013; Staksrud et al., 2013).

At the same time, it has been argued that discussions about adolescents and digital technologies should not only focus on online risks, but also need to take online opportunities into account (Livingstone, Mascheroni, et al., 2017). As we have seen, digital technologies offer a broad range of opportunities for entertainment, communication, information and education that teenagers can take advantage of (Chisholm, 2006; Ktoridou et al., 2012; Livingstone \& Helsper, 2010; Vandoninck et al., 2010).

Regarding digital skills, it is suggested that more digitally skilled teenagers will take better advantage of the multiple options offered by online media. However, research has usually focused on the relationship between digital skills and online risks, with fewer studies analysing the role of these skills in promoting online opportunities. 
This is because research "on the positive effects of media is not as robust as that on their negative effects" (Valkenburg \& Piotrowski, 2017, p. 179).

In any case, previous studies suggest that those who have more Internet skills or digital skills benefit more from online opportunities (S.-J. Lee \& Chae, 2012; Livingstone \& Helsper, 2010; Nikken \& Schols, 2015; Sonck \& de Haan, 2013). Therefore, the more digital skills teenagers have, the more online opportunities they enjoy, but also, the more risks they encounter. Thus, skills, opportunities and risks would all be positively correlated. Consequently, efforts to reduce online risks would be likely to constrain minors' skills and opportunities (Livingstone, 2017).

Given this fact, more research is needed to explore the impact that digital skills can have on both online risks and opportunities, since finding the right balance between accessing online opportunities and experiencing online risks remains a challenge (Vandoninck et al., 2010).

\subsection{Summary and Conclusions}

In this chapter, we have provided a review of the different types of online risk behaviours (contact with strangers, sexting, exposure to pornography, exposure to violence and cyberbullying) and their consequences for minors. Although not all online risks result in actual harm, they can have serious psychological consequences for adolescents, such as causing depression or anxiety. Nonetheless, throughout these pages we have emphasised the importance of preventing online risks from obscuring online opportunities. Thus, the use of digital media also offers a broad range of opportunities that adolescents can take advantage of. Moreover, research has shown that the use of digital media for learning presents benefits to students.

Taking all of this into consideration, we cannot deprive adolescents of the use of digital devices. The solution should be to provide minors with the tools to be able to use these technologies safely. Traditionally, it was believed that the key was the 
development of digital skills. That is, it was assumed that, through a process of digital literacy, children could manage online risks and maximise online opportunities offered by interactive communication. Nevertheless, as we have seen in this chapter, previous research has found that digital skills do not reduce online risk behaviours. In fact, more skilled adolescents experience more online risks. At any rate, digital skills would still be important as more digitally skilled teenagers take better advantage of online opportunities. However, empirical studies are scarce and more research is needed to clarify the role of digital skills in online risks and online opportunities.

Because digital skills do not reduce online risk behaviours, other solutions have been sought. Over the last few years, efforts have been made with the aim of responding to the different online risks as new technologies have developed. The goal of these efforts has been to promote digital safety among children and adolescents. We can distinguish between three ways of promoting this safety: technological mediation, parental mediation and educational interventions. In the next chapter we will describe these options for promoting digital safety and their outcomes. 



\section{Chapter 4 .}

\section{PROMOTING}

\section{DIGITAL SAFETY}

G iven concerns about online risks and online opportunities, which were mentioned in the previous chapter, all stakeholders involved, parents, educators, policymakers and researchers, aim to answer the question of what we should do about it. Hence, a growing body of research has been focusing on how to safeguard children and young people when using interactive communication and digital devices, and, at the same time, how to maximise online opportunities and benefits for them. Several options have been proposed over time: technological mediation, parental mediation and educational interventions.

Consequently, the purpose of this chapter is to review the research on the efficacy of these strategies in improving minors' empowerment, in promoting online opportunities and in reducing online risks. We will also briefly review the legislation adopted by policymakers with digital safety in mind.

\subsection{Technological Mediation: Use of Filtering and Control Software}

Technological mediation takes place by using filtering, blocking and controlling (or monitoring) software. The aim of this sort of mediation is to restrict minors' access to inappropriate or questionable online materials that could be considered harmful for them (Chibnall, Wallace, Leicht, \& Lunghofer, 2006; Meeder, 2005). According to 
RISKS OF INTERACTIVE COMMUNICATION IN ADOLESCENTS. DIGITAL LITERACY DIAGNOSIS AND INTERVENTION

Valcke et al. (2011), there are three main types of filtering and blocking software: inclusion (based on safe pages or a list of acceptable sites), exclusion (based on unsafe pages or a list of unacceptable sites), and content filtering software (instant scanning of websites). Furthermore, through controlling software, parents can monitor and track a child's online activity (e.g., keep track of the websites their child has visited). Finally, through time limiting software parents can set limits on how much time or at what time their child can use digital devices (Çankaya \& Odabaşi, 2009) .

Therefore, this type of software offers parents and schools the possibility of monitoring children's online activities (what websites they visit, and for how long), blocking access to unapproved sites and to advertising, blocking unwanted contact from adults, blocking minors' personal information from being posted, blocking inappropriate images, videos or texts, and limiting time spent online (Çankaya \& Odabaşi, 2009; Chibnall et al., 2006; Daud, Omar, Hassan, Bolong, \& Teimouri, 2014).

It has been said that the use of filtering and blocking software could be a useful tool for protecting children and adolescents from online risks (Çankaya \& Odabaşi, 2009; T. H. Tsai, Wei, \& Tsai, 2014). In fact, some researchers argue that parents should make an effort to learn how to use this software since it can help safeguard their children (Daud et al., 2014). According to them, technical restriction seems to be a good strategy "in promoting children's positive use of the Internet" (Daud et al., 2014, p. 367)

Nonetheless, research has revealed that families tend not to use this type of mediation (Fleming, Greentree, Cocotti-Muller, Elias, \& Morrison, 2006; Livingstone, Ólafsson, O'Neill, \& Donoso, 2012; G. Martínez \& Casado, 2018; Mitchell et al., 2003; T. H. Tsai et al., 2014), as parents may be sceptical about the effectiveness of this software, may not have enough knowledge of computers or may prefer active methods of parental mediation (Mitchell, Finkelhor, \& Wolak, 2005). In this sense, it is important 
to note that the use of this technological mediation "can run counter to parental efforts to foster a trusting relationship" (Haddon, 2013, p. 6).

Moreover, a review of the literature shows that, contrary to expectations, the use of this software does not reduce the chance of adolescents experiencing online risks (Fleming et al., 2006; Przybylski \& Nash, 2017; Ybarra, Finkelhor, Mitchell, \& Wolak, 2009). Similarly, some studies have found that blocking and filtering software could be ineffective as some products sometimes fail to block inappropriate material and sometimes block legitimate sites (Fleming et al., 2006; Overaa, 2014). Thus, they can be under-inclusive (failing to block inappropriate contents) or over-inclusive (blocking nonsexual or nonviolent content; Hunter, 200o). For example, if students are researching on topics such as sexually transmitted diseases or dangers of illegal drug use, the filtering software may prevent them from visiting safe sites, as they contain keywords like "sex" or "drugs" (Meeder, 2005).

In a study aimed at quantifying the extent to which pornography-blocking software limits access to health information sites (Richardson, Resnick, Hansen, Derry, \& Rideout, 2002), it was found that at the least restrictive blocking setting, configured to block only pornography, the software blocked $1.4 \%$ of health information sites and $87 \%$ of porn sites; at moderate settings, the blocking rate was $5 \%$ for health information and $90 \%$ for pornography; and at the most restrictive setting, the blocking rate was $24 \%$ for health information and $91 \%$ for pornography. Similarly, in another study (Hunter, 200o) it was found that filters fail to block objectionable content $25 \%$ of the time and improperly block $21 \%$ of benign content.

Consequently, this software cannot guarantee full protection. In this regard, Livingstone et al. (2012) assume that the use of filtering and blocking software can create a false sense of security that makes parents think "that by applying certain types of software, children will be safe online without them having to do more or engage with their children's Internet use" (p.17). Additionally, adolescents could use devices 
that do not have this software installed (e.g., when they use their friends' computers), and they would be unprotected against online risks. Thus, technological mediation would be only effective when young people are using their own devices.

In view of the above, technological mediation would be ineffective in reducing online risks or promoting digital safety. Moreover, the use of filtering and blocking software eliminates the opportunity to teach children and young people about safe, appropriate and ethical use of digital media (Nantais \& Cockerline, 2010). We are depriving them of the opportunity to learn how to navigate safely, how to evaluate the accuracy of information retrieved or how to make appropriate choices (Overaa, 2014). For that reason, scholars conclude that teenagers should be educated to use devices responsibly everywhere, instead of trying to protect them by installing software (Przybylski \& Nash, 2017; Šimandl \& Vaníček, 2017). Therefore, rather than using filtering, blocking and controlling software, it would be a better idea to teach adolescents about safety. In this way, they will have "internalized" tools and not external tools on their devices when accessing the online world.

\subsection{Parental Mediation of Adolescents' Digital Media Use}

For decades, scholars have acknowledged the role of parents in influencing and regulating adolescents' behaviours (Buijzen \& Valkenburg, 2005; Dornbusch, Ritter, Leiderman, Roberts, \& Fraleigh, 1987; Miller, 2002; Steinberg \& Morris, 2001). Although teenagers tend to be independent, scientific evidence has shown that parenting practices affect adolescents' behaviours and interactions (B. B. Brown \& Bakken, 2011). Thus, parents, and the family environment in general, play an important role in the development and learning of adolescents. In general, literature on these parental strategies indicates the existence of four parental styles (authoritative, authoritarian, permissive and neglectful) that have different outcomes for adolescents' development (see Table 11). 
In the case of media, parents can also determine, in a certain way, the relationship between adolescents and media. That is, the way that parents manage adolescents' media use might influence the effects that media have on their children. In fact, the "role of parents is prominent since most of this use occurs within the home" (Pasquier, Simoes, \& Kredens, 2012, p. 219).

Table 11.

Types of parental styles

\begin{tabular}{ll}
\hline Parental Style & Characteristics \\
\hline \multirow{3}{*}{ Authoritative } & $\begin{array}{l}\text { Parents are demanding and responsive; they control, but do not } \\
\text { restrict. They have awareness of their child's life and have open } \\
\text { communication with them. This parental style has been associated } \\
\text { with high levels of performance and strong school engagement. } \\
\text { Authoritarian }\end{array}$ \\
$\begin{array}{l}\text { Parents are demanding, but not responsive. They use strict control } \\
\text { over their child and discourage open communication. This has been } \\
\text { associated with passivity in children. }\end{array}$ \\
$\begin{array}{l}\text { Parents are responsive, but not demanding. There is a lack of parental } \\
\text { Permissive } \\
\text { control; parents allow their children to behave autonomously. This } \\
\text { may leave minors more impulsive and has been associated with } \\
\text { underachievement. }\end{array}$ \\
$\begin{array}{l}\text { Parents are neither responsive nor demanding. There is no parental } \\
\text { control or involvement in the child's life. This has been associated with } \\
\text { high levels of task-irrelevant behaviour, passivity and a lack of self- } \\
\text { enhancing attributes in adolescents. }\end{array}$ \\
\hline
\end{tabular}

Note. Author's elaboration from Aunola, Stattin and Nurmi (200o)

Accordingly, there is a long tradition of research studying the concept of parental mediation within the field of children's and adolescents' media use. In this sense, it is essential to clarify the concept of parental mediation. Parental mediation consists of "the diverse practices through which parents try to manage and regulate their children's experiences with the media" (Livingstone, Mascheroni, Dreier, Chaudron, \& Lagae, 2015, p. 7). We can also define it as "encouraging children to set limits on their media use, and to use media safely, selectively, and judiciously" (Valkenburg \& Piotrowski, 2017, p. 250). Parental mediation strategies for media are 
based on the previous parental styles and they include rule-making and restrictions. They can be both positive (e.g., explaining, discussing, talking with children) and negative (e.g., disagreeing, criticising, establishing rules; Haddon, 2018; Livingstone \& Helsper, 2008).

At first, researchers focused on parental mediation of children's and teenagers' television viewing. At that time, researchers referred to three types of parental mediation: active or instructive, restrictive and co-viewing. Active mediation includes conversations with minors about which programmes to watch, recommendations, explanations and evaluations of the content. It is related to the authoritative parental style. Restrictive mediation refers to setting rules for viewing, such as restrictions on time of viewing, or prohibiting some types of content. It is related to the authoritarian parental style. Finally, co-viewing consists of watching television together, driven by a common interest, without discussion of content (Valkenburg, Krcmar, Peeters, \& Marseille, 1999; Warren, 2001).

Nowadays, the focus is on parental monitoring of digital media, such as computers or mobile phones. According to the literature, in this case there are two major forms of parental mediation: active or instructive, and restrictive (V. H. H. Chen \& Chng, 2016; Kirwil, 2009; W. Shin, Huh, \& Faber, 2012). Active mediation takes place when parents talk to their child about the use of digital media and provide them with guidance and advice (V. H. H. Chen \& Chng, 2016). Restrictive mediation refers to the regulation of online activities through the use of rules, such as controlling adolescents' time spent online (V. H. H. Chen \& Chng, 2016; Valcke et al., 2011). Parents usually exert these restrictions with the aim of avoiding negative effects or as a way of punishing their child (Zaman, Nouwen, Vanattenhoven, de Ferrerre, \& Looy, 2016). As we said previously, traditional parental mediation of television included a third form, co-viewing. However, in the case of digital media, this option is less feasible due to physical constraints, such as the necessity to share a device, and the fact that shared 
use without any discussion is less likely (Valkenburg, Piotrowski, Hermanns, \& de Leeuw, 2013).

Nonetheless, not only are there differences between traditional and digital media in the types of mediating strategies available; mediation of adolescents' digital media use also involves some difficulties for adults. Therefore, according to some scholars (Livingstone \& Helsper, 2008; Livingstone et al., 2015), parents may have difficulties in managing online and digital devices since they are more technologically complex. Moreover, parents are usually less familiar with these devices than teenagers and, therefore, they might feel outsmarted (Daneels \& Vanwynsberghe, 2017). In fact, three out of four teenagers (11-16 years old) claim to know more about the Internet than their parents (Sonck et al., 2012).

This situation presents parents with a dilemma. On the one hand, parents see the Internet as a source of funds for the development of their children, and indeed digital media "have many positive influences on teens' development" (Valkenburg \& Piotrowski, 2017, p. 262). However, on the other hand, they want to protect minors from inappropriate content (Carvalho, Francisco, \& Relvas, 2015). Moreover, they also have another dilemma of choosing between monitoring their children's use of digital media or respecting their children's right to privacy, autonomy and freedom of expression (Haddon, 2018; G. Martínez \& Casado, 2018). For this reason, "with little personal experience to draw on, parents are unsure about how to support their children's Internet use" (Livingstone \& Haddon, 2012, p. 8). This technological disadvantage provokes some parents, because of their ignorance of new technology, to renounce their responsibility or to resort to restricting the use of digital media.

In any case, as we can see, the focus of minors' digital security has usually been placed on parents. It is considered that their "responsibility for their children's education includes supervising use of the Internet in the most effective way" (Garmendia et al., 2012, p. 232). Therefore, the effectiveness of parental mediation of 
digital media has become a concern for policymakers, educators, parents and other stakeholders (Garmendia et al., 2012). In consequence, in recent years, researchers have been concerned with the impact that parental mediation could have on adolescents' online risk behaviours and online opportunities. It is a matter of concern if parental mediation strategies actually prevent harm or if they reduce opportunities (Livingstone \& Haddon, 2012). Moreover, due to the importance of digital literacy and digital skills, studies are also being carried out on the impact that this mediation could have on teenagers' digital skills.

\subsubsection{Impact of parental mediation on adolescents' online risks and opportunities}

Parental mediation has been generally considered as a useful strategy for risk prevention (Álvarez, Torres, Rodríguez, Padilla, \& Rodrigo, 2013). In fact, some scholars assume that parents play a "vital role in limiting the risks and harm to which their children may be exposed" (Garmendia et al., 2012, p. 231). For instance, research has found that active mediation can diminish positive attitudes about pornography among adolescents (Rasmussen, Ortiz, \& White, 2015) and the effects of media on adolescents' use of alcohol (Austin, Pinkleton, \& Fujioka, 20oo).

In the case of the digital environment, emerging evidence suggests that active parental mediation may work better than restrictive mediation in reducing online risks (Duerager \& Livingstone, 2012; Khurana, Bleakley, Jordan, \& Romer, 2015; Lwin, Stanaland, \& Miyazaki, 2008; W. Shin \& Kang, 2016). On the contrary, research has shown that restrictive mediation is not always effective (Mares, Stephenson, Martins, \& Nathanson, 2018; Valkenburg \& Piotrowski, 2017). Thus, considering previous studies, restrictive mediation is both positively and negatively associated with online risks (Cabello-Hutt, Cabello, \& Claro, 2017; Khurana et al., 2015; Lau \& Yuen, 2013; S.J. Lee, 2012; S.-J. Lee \& Chae, 2012; Liau et al., 2005; Livingstone, Ólafsson, et al., 2017; Mitchell et al., 2003; Sasson \& Mesch, 2014; W. Shin \& Ismail, 2014; W. Shin \& Kang, 2016). 
Notwithstanding this, some researchers argue that instead of worrying about online risks, parents should plan strategies for increasing children's positive use of the Internet (Daud et al., 2014). As said previously, scholars, policymakers, educators and parents have tended to be concerned primarily with the negative effects of media (Clark, 2011), although digital media provide adolescents with many opportunities for entertainment, communication and education. In this sense, parental restrictions may reduce online risks at the expense of the opportunities (S.-J. Lee \& Chae, 2012). For this reason, it is essential to analyse the relationship of parental mediation with online opportunities. According to the literature, active mediation is positively associated with minors' online opportunities (Ihmeideh \& Shawareb, 2014; Livingstone, Ólafsson, et al., 2017). In contrast, restrictive parental mediation is related with fewer opportunities in the digital environment (Cabello-Hutt et al., 2017; Daud et al., 2014; Garmendia et al., 2012; Livingstone, Ólafsson, et al., 2017).

\subsubsection{The role of digital skills in parental mediation of online risks and opportunities}

As we said previously, in addition to online risks and opportunities, researchers have recently also become concerned with the impact that parental mediation could have on adolescents' digital skills (Valcke, Bonte, De Wever, \& Rots, 2010; Zhang \& Zhu, 2016). Although some parents may be unfamiliar with these sorts of skills (Livingstone \& Haddon, 2012, p. 4), they play an important role in their children's learning. Therefore, it is crucial to analyse whether parents' mediation of adolescents' use of digital media has any influence on the development of such skills.

Some authors consider parental mediation as a key strategy in developing minors' skills for using and interpreting the media, and for promoting positive outcomes while preventing negative effects of media (Nikken \& Schols, 2015). Even so, empirical studies in this field are still very scarce. Four studies have shown a relationship between parental mediation and the digital literacy of children. However, 
one of these studies does not distinguish between different types of parental mediation (Nikken \& Schols, 2015) and another only measures digital skills through the parents' perceptions (Zhang \& Zhu, 2016). Nevertheless, some scholars suggest that children's reports are more reliable when it comes to measuring their skills (Fujioka \& Austin, 2003; Nathanson, 2001; Symons, Ponnet, Emmery, Walrave, \& Heirman, 2017). Moreover, there are only two studies that have focused on parental mediation and digital skills among adolescents. Both of them conclude that active mediation is related to an increase in digital skills, whereas restrictive mediation reduces these skills (Cabello-Hutt et al., 2017; Duerager \& Livingstone, 2012).

To recapitulate, in Table 12 we present a summary of the research on the impact of the two styles of parental mediation on adolescents' digital skills, online risks and online opportunities. As research, especially on the influence on digital skills and online opportunities, is scarce, more research is needed to clarify the impact of parental mediation. It is essential to assess if the mediation developed by parents, who are concerned about the risks, affects the development of digital skills.

Table 12.

Impact of parental mediation on digital skills and online risks and opportunities

\begin{tabular}{|c|c|c|c|}
\hline Mediation & Online Risks & Online Opportunities & Digital Skills \\
\hline Active & $\begin{array}{l}\text { It is negatively } \\
\text { related to them }\end{array}$ & It is positively related & It increases them \\
\hline Restrictive & $\begin{array}{l}\text { No agreement. It is both } \\
\text { positively and negatively } \\
\text { related to them }\end{array}$ & $\begin{array}{l}\text { It is negatively } \\
\text { related }\end{array}$ & It reduces them \\
\hline
\end{tabular}




\subsection{Educational Interventions}

In addition to parental and technological mediation, the focus of digital safety has also been placed on the importance of education, whether in schools or through educational initiatives. Thus, in the last few years, some researchers have held that promoting education and awareness about online risks among adolescents is the best preventive measure (Ang, 2015; Patchin \& Hinduja, 2010a; Tejedor \& Pulido, 2012). Thereupon, this educational view has focused on schools and teachers, and on interventions developed by other organisations, such as political authorities or universities.

First, and with reference to teachers, the problem is that they sometimes lack sufficient knowledge and skills (Bennett, Maton, \& Kervin, 2008; Šimandl \& Vaníček, 2017; Sonck \& de Haan, 2014), as is the case with parents. Under these circumstances, some schools "find it easier to prohibit the use of electronic devices rather than provide support" (Smahel \& Wright, 2014, p. 144). Therefore, the most common forms of school engagement with digital safety are lessons about online safety, police information sessions and awareness-raising campaigns or interventions (Smahel \& Wright, 2014).

\subsubsection{Interventions promoting digital safety}

It has been highlighted the necessity of implementing and evaluating online safety and digital literacy programmes. For these reason, some educational packages and interventions have been developed for these population (Vanderhoven, Schellens, \& Valcke, 2015), especially by political and educational authorities (Childnet International, 2016; Elkartea Suspergintza, 2015; Junta de Castilla y León, 2009; Luengo, 2011; Protégeles, Daphne, Super Kids, \& Europea, 2013). These educational packages usually provide minors with information about online safety, such as how to protect their personal data, how to seek advice if they suffer cyberbullying or how to protect their digital devices from viruses. 
RISKS OF INTERACTIVE COMMUNICATION IN ADOLESCENTS.

DIGITAL LITERACY DIAGNOSIS AND INTERVENTION

However, the problem is that these educational initiatives usually do not have a theoretical base or an evaluation of their impacts (Chibnall et al., 2006; Della Cioppa, O’Neil, \& Craig, 2015; Fernández-Montalvo, Peñalva, Irazabal, \& López-Goñi, 2017; Mishna, Cook, Saini, Wu, \& MacFadden, 2011; Vanderhoven, Schellens, \& Valcke, 2014a, 2014b; Vanderhoven, Schellens, Vanderlinde, \& Valcke, 2016). The absence of evaluations means that we have no evidence that these initiatives are effective or even have any effect. Moreover, some of the studies only have qualitative evaluation, mostly through focus groups (Barnard-Wills, 2012; Barnard-Wills \& Ashenden, 2015; Davidson, Martellozzo, \& Lorenz, 2009; Vanderhoven et al., 2014b), but they lack quantitative data.

In this regard, we maintain that experiments (or quasi-experiments) are essential when we develop interventions, as they are the most rigorous technique for checking their effectiveness. Only through the evaluation of interventions can we evaluate cause-effect relationships and improve future educational initiatives. Therefore, in Table 13 we present a review of interventions against online risks for children and adolescents in which the researchers have conducted an experiment.

Most of these interventions consist of sessions conducted by the researchers during class time. In these sessions, researchers teach content related to online risks, then students do some exercises and debate these topics (Fernández-Montalvo et al., 2017; Ortega-Ruiz, Del Rey, \& Casas, 2012; Vanderhoven et al., 2014a). In other interventions, researchers provide the material and teachers conduct the sessions during class time (Chaux, Velásquez, Schultze-Krumbholz, \& Scheithauer, 2016; Chibnall et al., 2006; Cross et al., 2016; Gradinger, Yanagida, Strohmeier, \& Spiel, 2016; Palladino, Nocentini, \& Menesini, 2016).

Most initiatives seem to be effective, as students in the intervention groups gained more knowledge of the topic or related skills (Chibnall et al., 2006; FernándezMontalvo et al., 2017; Vanderhoven et al., 2014a; Zhang-Kennedy, Abdelaziz, \& 
Chiasson, 2017), or showed a significant reduction in a type of online risk behaviour (Chaux et al., 2016; Cross et al., 2016; Gradinger et al., 2016; Ortega-Ruiz et al., 2012; Palladino et al., 2016; Williford et al., 2013), in comparison with control groups. Therefore, considering previous research, we can assume that educational interventions are effective both in reducing online risk behaviours and in increasing digital skills.

On the other hand, as far as we know, programmes that take advantage of the technology to implement interventions against online risks have focused only on cyberbullying, but not on other risks; these include Friendly Attac (Desmet et al., 2017), the KiVa Programme (Williford et al., 2013) and NoTrap! (Palladino et al., 2016). There is only one digital initiative related to online privacy, Cyberheroes (ZhangKennedy et al., 2017), which was developed for children under ten years old. Nevertheless, Nocentini, Zambuto and Menesini (2015) say the use of information and communication technologies in interventions "as a learning method has several advantages in respect to traditional methods" (p.52), such as being attractive to adolescents, allowing users to simulate real world experiences and practice new skills, or using more flexible instruments. Accordingly, more research with interventions that take advantage of the technology in this field is required 
RISKS OF INTERACTIVE COMMUNICATION IN ADOLESCENTS.

DIGITAL LITERACY DIAGNOSIS AND INTERVENTION

Table 13.

Educational interventions against online risks

\begin{tabular}{|c|c|c|c|c|}
\hline Study & $\begin{array}{l}\text { Topic, characteristics and aim of } \\
\text { the intervention }\end{array}$ & $\begin{array}{l}\text { Theoretical } \\
\text { background }\end{array}$ & $\begin{array}{l}\text { Sample, study design, duration and } \\
\text { measurement }\end{array}$ & Results \\
\hline $\begin{array}{l}\text { (Chaux et } \\
\text { al., 2016) }\end{array}$ & $\begin{array}{l}\text { Cyberbullying } \\
\text { Media Heroes: Activities } \\
\text { implemented by the teacher: role- } \\
\text { playing, debates, analyses of } \\
\text { written stories, news and films, } \\
\text { cooperative learning, and student } \\
\text { parent presentations. } \\
\text { It seeks to prevent cyberbullying by } \\
\text { promoting empathy, providing } \\
\text { knowledge about definitions, } \\
\text { Internet risks, safety and legal } \\
\text { consequences, and promoting } \\
\text { assertive ways for bystanders to } \\
\text { intervene. }\end{array}$ & $\begin{array}{l}\text { Theory of } \\
\text { Planned } \\
\text { Behaviour }\end{array}$ & $\begin{array}{l}722 \text { students (11-17 years old) } \\
\text { Two experimental (long and short } \\
\text { version) and one control group. } \\
\text { Teachers in control classes } \\
\text { followed the usual classes and did } \\
\text { not implement the programme } \\
\text { until the end of the experiment. } \\
\text { Long version: } 15 \text { sessions of } 45 \mathrm{~min} . \\
\text { Short version: } 4 \text { sessions of } 90 \mathrm{~min} \\
\text { on a single day. } \\
\text { Pre-test and post-test (six months } \\
\text { after the intervention). Measures: } \\
\text { European Cyberbullying Intervention } \\
\text { Project Questionnaire (traditional } \\
\text { bullying, traditional victimisation, } \\
\text { cyberbullying, cybervictimisation). }\end{array}$ & $\begin{array}{l}\text { Children in the long } \\
\text { intervention } \\
\text { showed a significant } \\
\text { decrease in } \\
\text { cyberbullying. The } \\
\text { intervention also } \\
\text { contributed to } \\
\text { increases in } \\
\text { empathy, } \\
\text { perspective-taking } \\
\text { skills, self-esteem, } \\
\text { and subjective } \\
\text { health. }\end{array}$ \\
\hline
\end{tabular}


CHAPTER 4. PROMOTING DIGITAL SAFETY

\begin{tabular}{|c|c|c|c|c|}
\hline Study & $\begin{array}{l}\text { Topic, characteristics and aim of } \\
\text { the intervention }\end{array}$ & $\begin{array}{l}\text { Theoretical } \\
\text { background }\end{array}$ & $\begin{array}{l}\text { Sample, study design, duration and } \\
\text { measurement }\end{array}$ & Results \\
\hline \multirow{6}{*}{$\begin{array}{l}\text { (Chibnall } \\
\text { et al., 2006) }\end{array}$} & \multirow{3}{*}{$\begin{array}{l}\text { Internet safety } \\
i \text {-SAFE curriculum: Five core 6o- } \\
\text { minute lessons about Internet safety }\end{array}$} & \multirow{6}{*}{ Constructivism } & 2009 students (9-14 years old) in $5^{\text {th }}$ & \multirow{6}{*}{$\begin{array}{l}\text { The treatment } \\
\text { group gained more } \\
\text { knowledge than the } \\
\text { control group }\end{array}$} \\
\hline & & & to $8^{\text {th }}$ grade & \\
\hline & & & One control and one experimental & \\
\hline & \multirow{3}{*}{$\begin{array}{l}\text { Its objective is instilling knowledge in } \\
\text { middle school students to assist } \\
\text { them to recognise and respond to } \\
\text { dangerous or inappropriate online } \\
\text { situations. }\end{array}$} & & $\begin{array}{l}\text { group. Students in the control group } \\
\text { followed the school's curriculum. }\end{array}$ & \\
\hline & & & Nine-month period & \\
\hline & & & $\begin{array}{l}\text { Pre-test and several post-tests: } \\
\text { Retention of knowledge }\end{array}$ & \\
\hline \multirow{5}{*}{$\begin{array}{l}\text { (Cross et } \\
\text { al., 2016) }\end{array}$} & Cyberbullying & \multirow{5}{*}{$\begin{array}{l}\text { Systemic socio- } \\
\text { ecological } \\
\text { approach }\end{array}$} & 3,382 students ( $13-14$ years old) in & \multirow{5}{*}{$\begin{array}{l}\text { The programme was } \\
\text { associated with a } \\
\text { significant decline } \\
\text { in cyber- } \\
\text { victimisation and } \\
\text { perpetration }\end{array}$} \\
\hline & \multirow{3}{*}{$\begin{array}{l}\text { Cyber Friendly Schools (CFS): } \\
\text { activities related to teaching staff } \\
\text { about technologies, increasing } \\
\text { students' awareness of their rights } \\
\text { and responsibilities online, and } \\
\text { providing students and parents with } \\
\text { cyberbullying prevention training. }\end{array}$} & & $8^{\text {th }}$ grade & \\
\hline & & & $\begin{array}{l}\text { One control and one experimental } \\
\text { group. Control schools } \\
\text { implemented their regular } \\
\text { classroom. }\end{array}$ & \\
\hline & & & One course: 12 hours of activities & \\
\hline & $\begin{array}{l}\text { It aims to reduce cyberbullying by } \\
\text { fostering positive behaviour using a } \\
\text { harm minimisation approach. }\end{array}$ & & $\begin{array}{l}\text { Pre-test and two post-tests: } \\
\text { Demographic variables and } \\
\text { cyberbullying scales }\end{array}$ & \\
\hline
\end{tabular}


RISKS OF INTERACTIVE COMMUNICATION IN ADOLESCENTS.

DIGITAL LITERACY DIAGNOSIS AND INTERVENTION

\begin{tabular}{|c|c|c|c|c|}
\hline Study & $\begin{array}{l}\text { Topic, characteristics and aim of } \\
\text { the intervention }\end{array}$ & $\begin{array}{l}\text { Theoretical } \\
\text { background }\end{array}$ & $\begin{array}{l}\text { Sample, study design, duration and } \\
\text { measurement }\end{array}$ & Results \\
\hline $\begin{array}{l}\text { (Desmet et } \\
\text { al., 2017) }\end{array}$ & $\begin{array}{l}\text { Cyberbullying } \\
\text { Friendly Attac: Serious digital game } \\
\text { It is designed to promote positive } \\
\text { bystander behaviour and reduce } \\
\text { negative bystander behaviour. }\end{array}$ & $\begin{array}{l}\text { Intervention } \\
\text { mapping } \\
\text { protocol, } \\
\text { Reasoned action } \\
\text { approach, Social } \\
\text { cognitive theory, } \\
\text { Bystander } \\
\text { intervention } \\
\text { model, Self- } \\
\text { determination } \\
\text { theory, } \\
\text { Mechanics, } \\
\text { Dynamics, } \\
\text { Aesthetics. }\end{array}$ & $\begin{array}{l}249 \text { students (13-14 years old) in } 8^{\text {th }} \\
\text { grade } \\
\text { One control and one experimental } \\
\text { group. Students in the control } \\
\text { group followed the usual classes } \\
\text { and received the intervention after } \\
\text { the follow-up measurement was } \\
\text { completed. } \\
30 \text { minutes of play. Three tests: one } \\
\text { week before intervention (To), } \\
\text { after intervention (T1), and at a } 4^{-} \\
\text {week follow-up (T2). } \\
\text { Measures: sociodemographic } \\
\text { information, cyberbullying } \\
\text { prevalence, bystander behaviour } \\
\text { and determinants of this } \\
\text { behaviour. }\end{array}$ & $\begin{array}{l}\text { Intervention } \\
\text { resulted in } \\
\text { significant, small, } \\
\text { desired effects on } \\
\text { certain behavioural } \\
\text { determinants and } \\
\text { on quality of life. } \\
\text { However, } \\
\text { witnessing of } \\
\text { cyberbullying } \\
\text { decreased less in } \\
\text { the intervention } \\
\text { than in the control } \\
\text { condition. }\end{array}$ \\
\hline
\end{tabular}


CHAPTER 4. PROMOTING DIGITAL SAFETY

\begin{tabular}{|c|c|c|c|c|}
\hline Study & $\begin{array}{l}\text { Topic, characteristics and aim of } \\
\text { the intervention }\end{array}$ & $\begin{array}{l}\text { Theoretical } \\
\text { background }\end{array}$ & $\begin{array}{l}\text { Sample, study design, duration and } \\
\text { measurement }\end{array}$ & Results \\
\hline $\begin{array}{l}\text { (Fernández } \\
\text {-Montalvo } \\
\text { et al., 2017) }\end{array}$ & $\begin{array}{l}\text { Digital literacy } \\
\text { Three sessions with these lines: (a) } \\
\text { presentation of the thematic focus; } \\
\text { (b) specific activities for acquiring } \\
\text { the competences (c) final } \\
\text { discussion. } \\
\text { It aims to improve the participants' } \\
\text { digital literacy as a way of } \\
\text { preventing the development of } \\
\text { risky behaviour in their use of the } \\
\text { Internet }\end{array}$ & - & $\begin{array}{l}309 \text { students (10-13 years old) in } 6^{\text {th }} \\
\text { grade } \\
\text { One control and one experimental } \\
\text { group. The control group followed } \\
\text { the usual programme of classes. } \\
\text { Three sessions lasting two hours } \\
\text { each, during one week. } \\
\text { Pre-test, post-test and six months } \\
\text { post-test: digital literacy level. Pre- } \\
\text { test also sociodemographic data. }\end{array}$ & $\begin{array}{l}\text { The experimental } \\
\text { group reached a } \\
\text { significantly higher } \\
\text { degree of digital } \\
\text { literacy }\end{array}$ \\
\hline
\end{tabular}


RISKS OF INTERACTIVE COMMUNICATION IN ADOLESCENTS.

DIGITAL LITERACY DIAGNOSIS AND INTERVENTION

\begin{tabular}{|c|c|c|c|c|}
\hline Study & $\begin{array}{l}\text { Topic, characteristics and aim of } \\
\text { the intervention }\end{array}$ & $\begin{array}{l}\text { Theoretical } \\
\text { background }\end{array}$ & $\begin{array}{l}\text { Sample, study design, duration and } \\
\text { measurement }\end{array}$ & Results \\
\hline $\begin{array}{l}\text { (Gradinger } \\
\text { et al., 2016) }\end{array}$ & $\begin{array}{l}\text { Cyberbullying and } \\
\text { Cyber-Victimisation } \\
\text { ViSC Social Competence } \\
\text { Programme: teachers are trained in } \\
\text { how to recognise bullying cases; } \\
\text { how to tackle acute bullying cases; } \\
\text { and how to implement preventive } \\
\text { measures at the school and the } \\
\text { class levels. The class project aims } \\
\text { to empower students to take } \\
\text { responsibility for what happens in } \\
\text { their class. } \\
\text { It aims to reduce aggressive } \\
\text { behaviour and bullying, and to } \\
\text { foster social and intercultural } \\
\text { competencies in schools. }\end{array}$ & $\begin{array}{l}\text { Socio-ecological } \\
\text { model of } \\
\text { development }\end{array}$ & $\begin{array}{l}2,042 \text { students (10-15 years old) in } \\
5 \text { th to 8th grade } \\
\text { One control and one experimental } \\
\text { group. Students in the control } \\
\text { group followed the regular lessons. } \\
\text { One academic year } \\
\text { Pre-test, post-test and follow-up } \\
\text { test: Cyberbullying and cyber- } \\
\text { victimisation, traditional } \\
\text { aggression and traditional } \\
\text { victimisation, bullying perpetration } \\
\text { and bullying victimisation, physical } \\
\text { aggression and physical } \\
\text { victimisation, relational aggression } \\
\text { and relational victimisation, } \\
\text { Internet usage, class climate, ethnic } \\
\text { diversity }\end{array}$ & $\begin{array}{l}\text { ViSC was effective } \\
\text { in preventing } \\
\text { cyberbullying and } \\
\text { cyber-victimisation } \\
\text { after one year of the } \\
\text { programme }\end{array}$ \\
\hline
\end{tabular}


CHAPTER 4. PROMOTING DIGITAL SAFETY

\begin{tabular}{|c|c|c|c|c|}
\hline Study & $\begin{array}{l}\text { Topic, characteristics and aim of } \\
\text { the intervention }\end{array}$ & $\begin{array}{l}\text { Theoretical } \\
\text { background }\end{array}$ & $\begin{array}{l}\text { Sample, study design, duration and } \\
\text { measurement }\end{array}$ & Results \\
\hline \multirow{3}{*}{$\begin{array}{l}\text { (Ortega- } \\
\text { Ruiz et al., } \\
2012 \text { ) }\end{array}$} & $\begin{array}{l}\text { Cyberbullying and problems linked } \\
\text { with the use of the Internet }\end{array}$ & \multirow{3}{*}{$\begin{array}{l}\text { Theory of } \\
\text { normative social } \\
\text { behaviour }\end{array}$} & $\begin{array}{l}893 \text { students (11-19 years old) in } \\
\text { secondary education }\end{array}$ & \multirow{3}{*}{$\begin{array}{l}\text { The experimental } \\
\text { group showed } \\
\text { improvement both } \\
\text { in comparison with } \\
\text { the control group } \\
\text { and with the pre- } \\
\text { and post- } \\
\text { measurement. }\end{array}$} \\
\hline & $\begin{array}{l}\text { ConRed programme: Eight sessions, } \\
\text { that covered exploration of the } \\
\text { preconceived ideas, debates and } \\
\text { exercises, conducted by the } \\
\text { researchers. }\end{array}$ & & $\begin{array}{l}\text { One control and one experimental } \\
\text { group. Students in the control } \\
\text { group followed the regular lessons. } \\
\text { Three months: eight sessions } \\
\text { conducted with the students }\end{array}$ & \\
\hline & $\begin{array}{l}\text { It seeks to promote a positive use } \\
\text { of the Internet: to improve } \\
\text { perceived control over information } \\
\text { on the Internet, to reduce the time } \\
\text { dedicated to digital device usage, } \\
\text { and to prevent and reduce } \\
\text { cyberbullying. }\end{array}$ & & $\begin{array}{l}\text { Pre- and post-test. Scales: } \\
\text { Perceived information control, } \\
\text { Internet-related experiences, } \\
\text { European cyberbullying } \\
\text { intervention project, European } \\
\text { bullying intervention project, Basic } \\
\text { empathy and School climate. }\end{array}$ & \\
\hline
\end{tabular}


RISKS OF INTERACTIVE COMMUNICATION IN ADOLESCENTS.

DIGITAL LITERACY DIAGNOSIS AND INTERVENTION

\begin{tabular}{|c|c|c|c|c|}
\hline Study & $\begin{array}{l}\text { Topic, characteristics and aim of } \\
\text { the intervention }\end{array}$ & $\begin{array}{l}\text { Theoretical } \\
\text { background }\end{array}$ & $\begin{array}{l}\text { Sample, study design, duration and } \\
\text { measurement }\end{array}$ & Results \\
\hline $\begin{array}{l}\text { (Palladino } \\
\text { et al., 2016) }\end{array}$ & $\begin{array}{l}\text { Bullying and cyberbullying } \\
\text { NoTrap! Researchers manage the } \\
\text { first phase. The second phase is led } \\
\text { by peer educators, a group of } \\
\text { students who assume a role of } \\
\text { responsibility, after undergoing } \\
\text { specific training. } \\
\text { It aims to prevent and combat } \\
\text { traditional bullying and } \\
\text { cyberbullying }\end{array}$ & $\begin{array}{l}\text { Peer education } \\
\text { and peer } \\
\text { support models }\end{array}$ & $\begin{array}{l}\text { 1,083 students ( } 14-15 \text { years old) in } \\
9^{\text {th }} \text { grade } \\
\text { Two trials. One control and one } \\
\text { experimental group in each of the } \\
\text { trails. Students in the control group } \\
\text { followed the usual lesson and did not } \\
\text { receive any kind of intervention. } \\
\text { One course } \\
\text { Pre-test, mid-test, post-test: bullying } \\
\text { and victimisation, cyberbullying and } \\
\text { cybervictimisation }\end{array}$ & $\begin{array}{l}\text { The experimental } \\
\text { group showed a } \\
\text { significant decrease } \\
\text { over time for all the } \\
\text { variables, which } \\
\text { remained } \\
\text { unchanged in the } \\
\text { control group. This } \\
\text { reduction was } \\
\text { stable at follow-up } \\
\text { six months later. }\end{array}$ \\
\hline
\end{tabular}


CHAPTER 4. PROMOTING DIGITAL SAFETY

\begin{tabular}{|c|c|c|c|c|}
\hline Study & $\begin{array}{l}\text { Topic, characteristics and aim of } \\
\text { the intervention }\end{array}$ & $\begin{array}{l}\text { Theoretical } \\
\text { background }\end{array}$ & $\begin{array}{l}\text { Sample, study design, duration and } \\
\text { measurement }\end{array}$ & Results \\
\hline $\begin{array}{l}\text { (Vanderho } \\
\text { ven et al., } \\
\text { 2014a) }\end{array}$ & $\begin{array}{l}\text { Online risks: Content, contact and } \\
\text { commercial risks } \\
\text { Course: introduction by the } \\
\text { teacher, two-by-two exercise, class } \\
\text { discussion, voting cards and theory } \\
\text { (discussion of real life examples). } \\
\text { Its objective is to change } \\
\text { awareness, attitudes and behaviour } \\
\text { of teenagers on SNS }\end{array}$ & Constructivism & $\begin{array}{l}\text { 2,071 students (11-19 years old) in } \\
\text { secondary education. } \\
4 \text { groups. (1) No course, courses (2) on } \\
\text { content risks, (3) on contact risks, (4) } \\
\text { on commercial risks. Students in the } \\
\text { control group followed usual lessons. } \\
\text { One course (one hour) } \\
\text { Pre-test and post-test: awareness, } \\
\text { attitudes, behaviour. }\end{array}$ & $\begin{array}{l}\text { Results show that } \\
\text { the intervention } \\
\text { had an impact on } \\
\text { awareness and on } \\
\text { some behaviour } \\
\text { variables, but not } \\
\text { on attitudes. }\end{array}$ \\
\hline $\begin{array}{l}\text { (Williford } \\
\text { et al., 2013) }\end{array}$ & $\begin{array}{l}\text { Bullying and cyberbullying } \\
\text { KiVa Programme: student lessons } \\
\text { and themes, and a virtual learning } \\
\text { environment (computer game and } \\
\text { Internet forum, KiVa Street") } \\
\text { It focuses on enhancing the } \\
\text { empathy, self-efficacy, and } \\
\text { antibullying attitudes of } \\
\text { bystanders, who are neither bullies }\end{array}$ & - & $\begin{array}{l}18,412 \text { students in } 4^{\text {th }} \text { to } 9^{\text {th }} \text { grade } \\
\text { One control and one experimental } \\
\text { group. Students in the control group } \\
\text { followed the usual lessons. } \\
\text { One-year period } \\
\text { Pre-test and post-test: Olweus' } \\
\text { Bully/Victim Questionnaire }\end{array}$ & $\begin{array}{l}\text { KiVa students } \\
\text { reported lower } \\
\text { frequencies of } \\
\text { cybervictimisation } \\
\text { at post-test than } \\
\text { students in a } \\
\text { control condition }\end{array}$ \\
\hline
\end{tabular}


RISKS OF INTERACTIVE COMMUNICATION IN ADOLESCENTS.

DIGITAL LITERACY DIAGNOSIS AND INTERVENTION

\begin{tabular}{|c|c|c|c|c|}
\hline Study & $\begin{array}{l}\text { Topic, characteristics and aim of } \\
\text { the intervention }\end{array}$ & $\begin{array}{l}\text { Theoretical } \\
\text { background }\end{array}$ & $\begin{array}{l}\text { Sample, study design, duration and } \\
\text { measurement }\end{array}$ & Results \\
\hline \multirow{4}{*}{$\begin{array}{l}\text { (Zhang- } \\
\text { Kennedy et } \\
\text { al., 2017) }\end{array}$} & Online privacy & \multirow{4}{*}{$\begin{array}{l}\text { Instructional } \\
\text { design } \\
\text { principles for e- } \\
\text { learning }\end{array}$} & $\begin{array}{l}22 \text { children }(7-9 \text { years old) and } 22 \\
\text { parents ( } 30-44 \text { years old) }\end{array}$ & \multirow{4}{*}{$\begin{array}{l}\text { It increased } \\
\text { children's online } \\
\text { privacy knowledge } \\
\text { and reported } \\
\text { privacy behaviour, } \\
\text { and led to superior } \\
\text { one-week } \\
\text { knowledge } \\
\text { retention comparec } \\
\text { to the text-only } \\
\text { control. }\end{array}$} \\
\hline & Cyberheroes: educational & & One text and one eBook group & \\
\hline & privacy & & Pre-test, post-test and one-week & \\
\hline & $\begin{array}{l}\text { Its goal is to help children develop } \\
\text { skills in protecting their online } \\
\text { privacy. }\end{array}$ & & $\begin{array}{l}\text { test: privacy knowledge and } \\
\text { behaviour. Pre-test also } \\
\text { demographics and activities. Post- } \\
\text { test also usability. }\end{array}$ & \\
\hline
\end{tabular}




\subsubsection{Coping strategies for facing online risks}

In the last few years attention has also been paid to coping strategies. When experiencing online risks, there are certain skills that adolescents may need to cope with such risks (Rodríguez-de-Dios, van Oosten, \& Igartua, 2018). It has been show that the negative impact of online risks, such as cyberbullying, can be mitigated by coping strategies (Raskauskas \& Huynh, 2015). Thus, it has been proposed that one of the solutions could be to teach minors coping strategies in order to make them more resilient to online risks. As Livingstone and Haddon (2012) point out:

The more that children are equipped to work out solutions for themselves - through skills, greater resilience or access to online resources to support them - the less others will need to step in to guide or restrict their online activities. (p.8)

In a broad sense, coping strategies are ways people actually respond to stress (Skinner, Edge, Altman, \& Sherwood, 2003). These ways of managing stress can be cognitive or behavioural (Folkman \& Lazarus, 1988) and examples are seeking help, rumination, problem solving, denial, or cognitive restructuring (Skinner et al., 2003). These strategies have short term effects, with the resolution of the stressor, and long term effects on mental and physical health (Skinner et al., 2003; Tobin, Holroyd, Reynolds, \& Wigal, 1989). Thus, research has shown that coping strategies can be effective in reducing anxiety or depression symptoms caused by behaviours, such as cyberbullying (Lam \& Frydenberg, 2009; Machmutow, Perren, Sticca, \& Alsaker, 2012).

Traditional literature on copings strategies has been mainly developed from two classic models. Firstly, Roth and Cohen's (1986) model distinguishes between two types of coping: approach (tackle the problem directly) and avoidance (evade the problematic situation and think about other issues). Secondly, Folkman and Lazarus' (1988) model refers to two functions of coping: (a) problem focused coping, that is, coping directed at altering the situation that is causing distress; and (b) emotion 
RISKS OF INTERACTIVE COMMUNICATION IN ADOLESCENTS.

DIGITAL LITERACY DIAGNOSIS AND INTERVENTION

focused coping, that is, coping that regulates distress. Therefore, both models pose a dichotomy between active strategies (dealing with the problem and focusing on a direct solution) and passive strategies (escaping to avoid discomfort). It is important to highlight that these strategies are not mutually exclusive. Depending on the problem and the personal characteristics, both ways of coping can be applied, since coping is a multidimensional process (Folkman \& Lazarus, 1988). In this sense, passive strategies seem useful for reducing stress in the short term, whereas active strategies seem effective for "taking advantage of changes in a situation that might make it more controllable" (Roth \& Cohen, 1986, p. 813).

From these approaches, several typologies and scales, both for adults (Billings \& Moos, 1981; Carver, Scheier, \& Weintraub, 1989; Tobin et al., 1989), and children and adolescents (Brodzinsky et al., 1992; Causey \& Dubow, 1992; Ebata \& Moos, 1991; Maybery, Steer, Reupert, \& Goodyear, 2009; Ouyang, Xin, \& Chen, 2016; Williams \& Lisi, 1999) have been developed. However, lack of consensus about core categories has made the comparison of results from different investigations difficult (Skinner et al., 2003).

In any case, and considering coping strategies for minors, we highlight three scales. First, the Self-Report Coping Scale (Causey \& Dubow, 1992) that distinguishes five factors: seeking social support, self-reliance or problem solving, distancing, internalising and externalising. Second, the CRI-Y (Coping Responses Inventory-Youth Form; Ebata \& Moos, 1991) that consists of eight dimensions that reflect approach (logical analysis, positive reappraisal, guidance/support and problem solving) and avoidance (cognitive avoidance, resigned acceptance, alternative rewards and emotional discharge) coping domains. And third, the three coping styles of Seiffge-Krenke and Shulman (1990): active coping, internal coping and withdrawal.

In the case of online risks, coping strategies refer to how children and young people cope when they are faced "with something online that they find problematic" 
(Livingstone \& Haddon, 2012, p. 8), that is, after suffering a negative experience online (Vandoninck et al., 2013). There are very few studies specifically related to coping strategies and online risks, and those that are usually focus on cyberbullying (Aricak et al., 2008; Machackova, Cerna, Sevcikova, Dedkova, \& Daneback, 2013; Machmutow et al., 2012; Orel, Campbell, Wozencroft, Leong, \& Kimpton, 2017; Raskauskas \& Huynh, 2015; Riebel, Jäger, \& Fischer, 2009; Sittichai \& Smith, 2018; Sléglová \& Cerná, 2011; Völlink, Bolman, Dehue, \& Jacobs, 2013). Even so, and in the case of cyberbullying, there are not too many appropriate coping strategy scales because they have not been validated (Machackova et al., 2013; Orel et al., 2017), or because the studies are based only on qualitative exploratory research (Sléglová \& Cerná, 2011). Specific mention can be made of the cyberbullying-specific coping scale, that has three factors: depressive/emotional coping, seeking social support and avoidance/palliative coping (Völlink et al., 2013); and the Riebel, Jäger and Fischer's (2009) scale, with four types of coping: aggressive, helpless, cognitive and technical.

Nevertheless, and as said previously, research on coping strategies for different types of online risks is scarce (Livingstone, Haddon, \& Görzig, 2011; Vandoninck \& d'Haenens, 2015). In any case, three types of response have been pointed out (Vandoninck et al., 2013; Vandoninck, d'Haenens, \& Segers, 2012):

- Fatalistic response: This is a passive response. Children stop using the digital devices or they hope that the problem will go away. That is, they do not do anything to tackle the cause of the problem. In consequence, they may be upset for a short time or just feel indifferent about the problem. This type of response "can be interpreted as ignoring the problem without eliminating the actual cause, and involves missing online opportunities or the chance to build resilience" (Vandoninck et al., 2012, p. 209). 
- Communicative response: Children resort to seeking social support and talk to someone trustworthy, such as a friend, a teacher or a member of the family.

- Proactive response: This is considered the best adaptation or resilience to adversity. Through this response children aim to reduce or eliminate future harm.

From these types of coping strategies, the only scale of coping strategies for different online risks (Vandoninck \& d'Haenens, 2015) was developed. As we can see in Table 14, this scale has four types of strategies related to the three types of responses that we have seen.

Since exposure to risks may be difficult to control, more attention should be paid to coping strategies. The scarcity of existing research in this field suggests that vulnerable children are more likely to use passive coping strategies when they confront online risks. On the contrary, children with higher self-efficacy are more likely to use active coping strategies (d'Haenens, Vandoninck, \& Donoso, 2013). In this regard, and as we mentioned previously, active coping strategies might be more effective as a response to online risks since they are intended to reduce or eliminate harm in the future. Moreover, passive strategies "may further reduce their capacities for resilience and online opportunities" (Vandoninck et al., 2012, p. 209).

Consequently, considering that very few studies focus on coping strategies and resilience to risks in the online world (Vandoninck et al., 2012), further research is needed to analyse the role of coping strategies as an effective response to online risks. 
Table 14.

Scale of coping strategies

\begin{tabular}{ll}
\hline Coping strategy & Characteristics \\
\hline Indifference & The child hopes the problem will go away by itself and they do \\
not care about what happened. This strategy is related to the \\
fatalistic response. It is a passive strategy in which the child does \\
not care about what has happened or tries not to think about it. \\
When finding a problem, such as non-desired contact with \\
strangers, the child decides to click away, to stop using the \\
Internet, or to leave the device. That is, with the use of this \\
strategy, digital devices are avoided in order not to face the \\
previous online risks or new risks. This strategy is also related to \\
the fatalistic response. \\
After finding a problem, such as grooming, the child talks with \\
somebody (friends or parents) about the problem or seeks \\
information online. Therefore, in this case, the way to deal with \\
the unpleasant situation is to talk with acquaintances or to try to \\
find help online. This strategy is related to the communicative \\
response. \\
Faced with a problem, such as cyberbullying, the child deletes the \\
images or messages, blocks the unwanted contact, changes \\
privacy settings and reports the problem. This strategy is related \\
to the proactive response and through it the person aims to face \\
the problem and look for an effective way to avoid it.
\end{tabular}

Note. Author's elaboration from Vandoninck and d'Haenens (2015), Vandoninck and d'Haenens (2018) and Vandoninck, D’Haenens, and Segers (2012).

\subsection{Legislation on Digital Safety}

Although legislation on minors' digital safety is not a central point in this research, we consider this information of relevance. Therefore, in this section we will provide a brief review of the legislation that has been implemented in this field.

Over recent years, growing concerns about children's online safety have led to legal enforcement (Chibnall et al., 2006). In the mid-nineties the first regulatory and legislative interventions related to children's digital activity were made. Since then, there have been many new legal initiatives. Despite legal differences between 
countries, there is an international consensus on the importance of empowering children and young people to engage in the digital world and on the need to make this environment a safer place for them (O'Neill, 2018). Consequently, legislation aimed at achieving these goals has been developed around the world.

First, in Europe, the Safer Internet Programme was developed for the first time in 1999. From that moment, this programme has supported activities intended to fight illegal content, to involve society in children's online safety issues or to raise awareness. Since the adoption of the European Strategy to Make the Internet a Better Place for Children in 2012, this programme is referred to as Better Internet for Kids (BIK). In 2001, the Convention on Cybercrime of the Council of Europe was celebrated in Budapest with the aim of addressing cybercrime and increasing international cooperation on investigations (Fernández Pérez, 2016). Similarly, in 2007, the Council of Europe Convention on Protection of Children against Sexual Exploitation and Sexual Abuse, also known as "the Lanzarote Convention", was adopted. It establishes that states in Europe shall adopt specific legislation to criminalise online child pornography and grooming (O’Neill, 2018).

Secondly, in Spain, educational legislation has highlighted in the last few years the importance of teaching digital skills to minors (Area Moreira, Gutiérrez Martín, \& Vidal Fernández, 2011). In this way, Spanish educational law considers digital skills as key skills in the primary, secondary and high school curriculum (Order $\mathrm{ECD} / 65 / 2015)$. It also appears in the minimum teaching requirements established by the State for primary education (RD 126/2014) and for secondary and high school education (RD 1105/2014). In this same vein, the Spanish Council of Ministers approved in 2013 the "II Plan Estratégico Nacional de Infancia y Adolescencia 20132016 ", that also includes the usefulness of digital literacy for minors.

On the other hand, there are some Spanish laws aimed at protecting minors in this environment. However, few laws address this issue due to the fact that they can 
collide with fundamental rights, such as freedom of expression and information (Fernández Pérez, 2016). One of them, the RD 1720/2007, based on the Organic Law on Data Protection (15/1999) regulates the minimum age requirement to open an account on a social media network (14 years old) without parents' consent. The problem is that lots of children lie about their age to sign up for social media (Protégeles et al., 2013) and, therefore, this law is not effective. Moreover, the Organic Laws 5/2010 and 1/2015, which modified the Organic Law 10/1995, were developed with the aim of protecting minors from cyberbullying. These laws establish penalties for cybercrimes in Spain (Luengo, 2011).

Finally, in the United States, and with the aim of protecting the online privacy of children, the Children's Online Privacy Protection Act (COPPA) was enacted. It requires web sites to obtain parental permission before collecting, using, or disclosing any personal information from children under the age of ${ }_{13}$ (W. Shin et al., 2012; Youn, 2005). Likewise, in 1998, the federal Internet Crimes Against Children (ICAC) task force programme was developed by the United States Department of Justice's Office of Juvenile Justice and Delinquency Prevention (OJJDP) for preventing, investigating and prosecuting Internet crimes against children (Chibnall et al., 2006). Afterwards, the Children's Internet Protection Act (CIPA), a federal law passed in 2001, made use of filtering software mandatory for those schools that wanted to receive federal funding for technology (O'Neill, 2018; Overaa, 2014). It should be noted that this act has brought controversy, as many students, teachers, librarians and researchers have claimed that filtering software makes Internet research impossible (Meeder, 2005; Overaa, 2014).

At any rate, as we have seen throughout this section, online safety and digital skills among children and adolescents have also been the focus of attention of public policymakers. This has caused many laws and regulations to have been implemented on this issue. 
RISKS OF INTERACTIVE COMMUNICATION IN ADOLESCENTS.

DIGITAL LITERACY DIAGNOSIS AND INTERVENTION

\subsection{Summary and Conclusions}

In this chapter, we have presented a review of the research on the efficacy of the different types of strategies for promoting digital safety: technological mediation, parental mediation and educational interventions.

First, technological mediation, which takes place through the use of software, offers parents and schools the possibility of monitoring minors' online activities, blocking inappropriate web sites, images, videos or texts, and limiting time spent online. Although some scholars and policymakers have defended the use of this software, research has shown that parents tend not to use it and that it does not reduce the chance of adolescents experiencing online risks. Moreover, some scholars argue that it deprives minors of the opportunity to learn how to use digital media safely.

Secondly, parental mediation refers to the strategies that parents use to regulate their children's media use. In the case of digital media, there are two forms of parental mediation: active (providing adolescents with guidance and advice on the use of digital media) and restrictive mediation (regulating and monitoring minors' digital media use). Research has shown that active mediation is negatively related to minors' online risks, but is positively associated with their online opportunities. On the contrary, restrictive mediation is related to fewer online opportunities while its relationship with online risks is not clear. Regarding the relation between parental mediation and adolescents' digital skills, empirical studies are scarce. At any rate, available research suggests that active mediation is positively related to minors' digital skills, but restrictive mediation is negatively associated with them. Therefore, results suggest that parents should opt for other ways of mediation rather than restrictive mediation.

Finally, some educational interventions related to digital safety have been developed in the last few years. Nonetheless, some of them have no evaluation of their 
impact and it is impossible to know if they were effective in reducing online risks and in increasing online opportunities and digital skills for adolescents. In any case, those educational interventions for which researchers have conducted experiments have shown encouraging results. Thus, they were effective in increasing digital skills or knowledge about digital safety and in decreasing risky online behaviours among adolescents. In this sense, teaching of coping strategies has been proposed as a solution for mitigating the impact of online risks on adolescents. In a broad classification, coping strategies can be divided into passive strategies (e.g., to stop using the device or not to do anything) and active strategies (e.g., to talk to someone, to block the sender, to delete the image). Scholars suggest that active coping strategies might be more effective as they try to reduce or eliminate harm.

In conclusion, contrary to what happens with restrictive parental and technological mediation, active mediation and education have proved to be an effective tool for promoting adolescents' digital safety. Consequently, more research on the impact of active parental mediation on adolescents' outcomes is needed. On the other hand, considering the importance of digital skills and active coping strategies, and the effectiveness of educational interventions, more research with interventions that aim to develop these skills is required too. At any rate, for developing educational interventions it is essential to consider what makes them effective. Therefore, in the next chapter we will review this issue. 



\section{Chapter 5 .}

\section{MOBILE LEARNING AND}

NARRATIVE PERSUASION

$\mathbf{I}$ n previous chapters we have discussed the rapid development of ICT that enables interactive communication and the impact it has had on adolescents' lives. Moreover, we have analysed the importance of digital skills in this environment. Consequently, we have also paid attention to online risks and online opportunities and the role that digital skills play in relation to them. Finally, we have reviewed the different strategies for promoting digital safety among adolescents: technological mediation, parental mediation and educational interventions. According to research, we have concluded that educational interventions have proved to be an effective tool for promoting adolescents' digital safety and that the use of digital technology in such interventions could have some benefits.

Considering the above, in this chapter we will look at the use of mobile digital technologies in educational initiatives, that is, the use of mobile learning. We will also examine its theoretical bases and review research on the effectiveness of mobile learning that uses mobile applications. Likewise, we will discuss the effectiveness of the entertainment-education strategy, and the possibilities, effects and explanatory mechanisms of narratives. To conclude the chapter, we will analyse the possibility of combining the use of narrative persuasion and mobile learning. 
RISKS OF INTERACTIVE COMMUNICATION IN ADOLESCENTS.

DIGITAL LITERACY DIAGNOSIS AND INTERVENTION

\subsection{Mobile learning and its theoretical bases}

Mobile learning (m-learning) refers to the acquisition of knowledge through mobile technology, such as mobile phones or tablets (Chee, Yahaya, Ibrahim, \& Hasan, 2017). It has also been defined as "learning across multiple contexts, through social and content interactions, using personal electronic devices" (Crompton, 2013, p. 83). According to this definition, mobile learning can be formal or spontaneous and can happen in an academic setting or a non-academic setting. In any case, this learning modality always involves the use of personal digital devices. Accordingly, the development of mobile learning has been the consequence of the development of new digital mobile devices (Conde, García-Peñalvo, Alier, \& Piguillem, 2013). Hence, the advancements in wireless Internet and mobile technology have promoted a change in both education and educational technology (C. Y. Chang, Lai, \& Hwang, 2018; Crompton, 2013; El-Hussein \& Cronje, 2010).

Mobile learning has its origins in distance education and in e-learning (Crompton, 2013; Göksu \& Atici, 2013). Distance education is a method in which the learner studies on their own wherever they want without coming face to face with their teachers. Moreover, e-learning (electronic learning) consists on learning with electronic devices, such as computers or laptops. Accordingly, the big difference between electronic learning and mobile learning is that the latter offers portability since mobile phones and tablets are smaller and lighter than computers or laptops. In fact, portability is the most distinctive feature of mobile learning (Y. Park, 2011).

Previously, mobile devices were in a weak position with regard to computers due to the fact that they lacked functionality, screen size, processor speed and battery life (Crompton, 2013; Y. Park, 2011). Mobile devices have currently overcome these technical limitations and they are now perfectly equipped with many additional capabilities and features. Moreover, mobile devices are "convenient and ubiquitous in 
the lives of young people" (White \& Martin, 2014, p. 64). Therefore, they can perfectly compete at present with computers and laptops in the education field.

As we shall see, mobile technologies have characteristics, such as flexibility and ease of access, that make them valuable for learning purposes (Bano, Zowghi, Kearney, Schuck, \& Aubusson, 2018). The opportunities and outcomes that this learning modality offers have attracted interest from scholars. Consequently, there is a significant body of research relating to mobile learning outcomes and effectiveness (Bano et al., 2018; Göksu \& Atici, 2013; Liu et al., 2014). However, the integration of mobile learning within formal education is still in the early developmental stages (Sánchez-Prieto, Olmos-Migueláñez, \& García-Peñalvo, 2016).

Mobile learning has come to be widely studied in recent years because of its characteristics. First, mobile devices, especially mobile phones, are highly portable and have ease-of-use attributes, and apps are usually inexpensive or free (Stevenson \& Hedberg, 2017). The fact that they are easily carried allows learning not to be constrained by physical locations (C. Y. Chang et al., 2018; El-Hussein \& Cronje, 2010). Therefore, users can learn at any place and at any time (El-Hussein \& Cronje, 2010; Göksu \& Atici, 2013) and start and stop the learning process whenever they want (Göksu \& Atici, 2013). Consequently, mobile learning promotes the student's autonomous learning (Sánchez-Prieto et al., 2016).

Secondly, and considering the theory of constructivism, mobile devices can enhance active learning experiences. According to research, effective learning improves when students actively participate in learning (Su \& Cheng, 2015; Thinley, Geva, \& Reye, 2014). That is, constructivism has been demonstrated as an effective learning method (Göksu \& Atici, 2013). In this sense, Hamdani (2013) ensures that the best way to apply principles of constructivism is through the use of mobile devices.

Third, mobile learning can also promote students' engagement with the learning process. This engagement can be developed through three elements: (a) 
contingent interactions, for example, with touch screens; (b) extrinsic motivation and feedback, with responses to users' answers, such as motivational messages (e.g., "try again"), points, or badges; and (c) intrinsic motivation, with open-ended apps (HirshPasek et al., 2015).

Therefore, in order to be effective, educational interventions based on mobile learning principles should consider these theoretical bases (Hirsh-Pasek et al., 2015); humans learn best when they are actively involved, which connects with the theory of constructivism, and are engaged with the learning material, which connects with the gamification approach.

\subsubsection{Constructivist theory}

The constructivist theory is based on the work of Piaget and Vygotsky. It states that learning is an interpretive, recursive, nonlinear building process by active learners interacting with their surroundings (Fosnot \& Stewart, 2005). According to this theory, knowledge and new ideas or concepts are constructed by learners through experience (Hamdani, 2013; Naismith, Lonsdale, Vavoula, \& Sharples, 2004). Moreover, the constructivist theory relies on several principles, such as the construction principle (learners construct their knowledge by making connections between current and past knowledge) and the authenticity principle (learners profit from working with real life tasks; Cooperstein \& Kocevar-Weidinger, 2004; Crompton, 2013; Sandberg, Maris, \& De Geus, 2011).

In consonance with constructivism, we should present content that can be linked to previous knowledge and that can be applicable (Hamdani, 2013; Sandberg et al., 2011). Moreover, we should also provide learners with authentic learning activities, in order that they can make links between this learning task and real life situations (Cooner, Knowles, \& Stout, 2016; Crompton, 2013). Therefore, we must choose activities that stimulate real life situations in order to promote a better learning 
achievement (Cooperstein \& Kocevar-Weidinger, 2004). In that way, users will construct their own knowledge "from thinking critically and creatively to solve problems" (Crompton, 2013, p. 86). In this sense, and due to the portability of digital devices, mobile learning provides greater opportunities for learning in authentic settings (Liu et al., 2014; Naismith et al., 2004). That is, mobile learning gives us the opportunity to provide learners with activities that simulate real life situations, but also with activities that promote learning within an authentic context (e.g., educational mobile applications for teaching art at the museum or the gallery, or apps for teaching about animals at the zoo - Crawford, Holder, \& O'Connor, 2016; Martin \& Ertzberger, 2013; Sandberg et al., 2011).

Active learning is also a central concept in constructivism. According to this theory, learners actively construct their knowledge and do not simply register information in a passive way (Hirsh-Pasek et al., 2015; Naismith et al., 2004). That is, they learn by doing. Empirical research has supported this view by showing the numerous advantages of active participation in learning (Thinley et al., 2014).

Finally, it is important to emphasise that mobile learning has a strong relationship with constructivism, as technological developments allow learning environments to be created based on constructivist principles (Sandberg et al., 2011; Su \& Cheng, 2015). For example, features of mobiles devices, such as interactivity, can help to promote active learning. Research has shown that studies that have implemented mobile learning using the constructivist approach have had positive effects on knowledge achievement and motivation (Marzouki, Idrissi, \& Bennani, 2017).

In relation to online safety learning, Vanderhoven, Schellens and Valcke (2014a) reviewed constructivist principles and how they can be applied in educating teenagers about online risks. According to them, active learning can be applied through active exercises or scaffolding questions; authentic learning, through 
simulated SNS-profiles; multiple perspectives, with voting cards; and collaborative learning, through two-by-two exercises with peers. The results of their study showed that "time for individual reflection, rather than collaborative learning, appeared to be a critical aspect of effective educational materials if the objective is both raising awareness and changing unsafe behaviour on SNSs" (Vanderhoven et al., 2015, p. 6). In view of the above, the principles of constructivism, except collaborative learning, would be useful for learning activities related to online risks and online safety.

\subsubsection{Gamification}

Gamification consists of adding gaming elements, mechanics and principles to nongaming contexts, such as educational contexts, with the aim of enhancing motivation and engagement among the participants. Studies that have tested the efficacy of gamification have combined different motivational affordances: points, leader-boards, badges, stars, levels, story/theme, clear goals, quests and challenges, feedback, virtual rewards, progress bars, performance graphs and meaningful stories (Alsawaier, 2018; Çakıroğlu, Başıbüyük, Güler, Atabay, \& Yılmaz Memiș, 2017; Hamari, Koivisto, \& Sarsa, 2014; Khaleel, Sahari-Ashaari, Tengku Wook, \& Ismail, 2016; Sailer, Hense, Mandl, \& Klevers, 2013; Sardi, Idri, \& Fernández-Alemán, 2017; Su \& Cheng, 2015). For example, through avatars we let users to choose or create a character that will reflect their aspirations; through challenges and quests we give users a purpose; and through points and levels we encourage users to progress (Alsawaier, 2018). In this sense, it is important to note that gamification is not the same as game-based learning. Gamification only implies adding elements of games to enhance engagement and learning, but the final product is not designed for playing and has a non-game purpose (Alsawaier, 2018; Kasurinen \& Knutas, 2018).

The gamification approach draws on self-determination theory (SDT). This theory argues that human behaviour is motivated by three psychological needs: autonomy, competence and relatedness (Su \& Cheng, 2015). Autonomy would be 
related to experiencing choice over one's actions; competence to succeeding at challenges; and relatedness to a sense of mutual respect and interdependence (Alsawaier, 2018; Baard, Deci, \& Ryan, 2004). Correspondingly, players will be motivated if they experience competition, autonomy and social relatedness (Alsawaier, 2018; Sailer et al., 2013). Therefore, gamification would fulfil these needs. In this sense, scholars argue that motivation has a positive effect on learning achievement (Buckley \& Doyle, 2016).

Research has addressed the effectiveness of gamification and has found that it increases motivation and engagement (Alsawaier, 2018; Hamari et al., 2014). Moreover, findings also suggest that gamification allows students to obtain a higher learning achievement (Buckley \& Doyle, 2016; Pechenkina, Laurence, Oates, Eldridge, \& Hunter, 2017). According to that, research shows that the use of game elements in educational mobile apps promote motivation and engagement, which, in turn, facilitate learning (Attali \& Arieli-Attali, 2015; Çakıroğlu et al., 2017; Domínguez et al., 2013; Su \& Cheng, 2015). Therefore, and following these results, the use of gamification on mobile learning interventions would be useful for reaching better results.

Considering the above, a mobile learning intervention that aims to be effective should follow the basis of constructivism and gamification. Consequently, it should include active and authentic learning activities for increasing the acquisition of knowledge, and game elements, such as badges, for enhancing motivation, engagement and learning.

\subsubsection{Mobile acceptance}

The concept of mobile acceptance is based on the broader concept of technology acceptance. According to previous literature, technology acceptance can be defined as "users' perceptions of the ease of use and usefulness of the technology-enhanced system" (C. Y. Chang et al., 2018, p. 44). Concordantly, the Technology Acceptance Model (TAM) from Davis (1989) includes these two dimensions: perceived usefulness 
RISKS OF INTERACTIVE COMMUNICATION IN ADOLESCENTS.

DIGITAL LITERACY DIAGNOSIS AND INTERVENTION

(believing that using a system would enhance job performance) and perceived ease-of-use (believing than using a system would not need an effort). This model has been commonly used for studying the adoption of information system in educational and non-educational contexts (Sánchez-Prieto, Olmos-Migueláñez, \& García-Peñalvo, 2014) and, consequently, in mobile learning research (Al-Emran, Mezhuyev, \& Kamaludin, 2018).

In relation to this concept, mobile (technology) acceptance and mobile application acceptance can be defined as the perception of the ease of use and usefulness of a mobile technology or a mobile application. Previous research has shown that gamification and constructivism content promote technology and mobile acceptance (Baptista \& Oliveira, 2017; Elwood, Changchit, \& Cutshall, 2006). Moreover, technology acceptance has been shown to predict the effectiveness of the educational content (Al-hawari \& Mouakket, 2010). Consequently, as mobile acceptance predicts the effectiveness of an intervention, and constructivism and gamification predict learning achievements and mobile acceptance, we can assume that mobile learning interventions should follow the basis of constructivism and gamification in order to promote mobile acceptance and, as such, educational outcomes.

\subsection{Is Mobile Learning Effective? A Review of Previous App Interventions}

As seen previously, the use of mobile learning has gained substantial attention from researchers. Thus, several interventions have been developed recent years which have shown that mobile devices can have positive effects as they have learning benefits and can enhance learning (Chee et al., 2017; Cheung \& Slavin, 2013; Stevenson \& Hedberg, 2017; Tingir, Cavlazoglu, Caliskan, Koklu, \& Intepe-Tingir, 2017; W.-H. Wu et al., 2012).

As we stated in Chapter 4, we maintain that experiments (or quasiexperiments) are indispensable when developing this sort of educational intervention, 
since they are the most rigorous technique for checking effectiveness. Only through the evaluation of interventions can we evaluate cause-effect relationships and improve future mobile applications. In this sense, researchers in this field usually conduct quasi-experiments, and not experiments, since schools generally insist on using the usual school groups, making random assignment impossible (Ahmed \& Parsons, 2013; F. Martin \& Ertzberger, 2013; Sandberg et al., 2011).

In Table 15 we present a review of some experiments (or quasi-experiments) that have checked the effectiveness of educational interventions conducted using mobile applications. Thus, we do not consider other interventions with mobiles devices that have used other tools or features, such as SMS (short message service; Lu, 2008). Moreover, we only include experiments (or quasi-experiments) that use a design with a control group, as absence of such a control group implies that any change in knowledge or achievement will be attributed to the app and the influence of extraneous variables will not be considered (Cheung \& Slavin, 2013). Consequently, studies without a control group were excluded from the analyses (Burgess \& Murray, 2014; Meilan, Trussell, Gallegos, \& Asam, 2015; Teri et al., 2014).

As we can see in the table, 8o percent of the apps were more successful in promoting better learning outcomes than traditional lessons (Ahmed \& Parsons, 2013; Briz-Ponce, Juanes-Méndez, García-Peñalvo, \& Pereira, 2016; Jeno, Grytnes, \& Vandvik, 2017; Jou, Lin, \& Tsai, 2016; Kiger, Herro, \& Prunty, 2012; Ling, Harnish, \& Shehab, 2014; Noguera, Jiménez, \& Osuna-Pérez, 2013; Q. Wu, 2015; Yang, Tseng, Liao, \& Liang, 2013; Yoo \& Lee, 2015). Moreover, one out of three researchers used mobile learning theories as theoretical background (Briz-Ponce et al., 2016; Kiger et al., 2012; Nickerson, Rapanta, \& Goby, 2017; Sandberg et al., 2011; Yoo \& Lee, 2015). Only one study (6\% of the total) relies on the constructivist theory (Sandberg et al., 2011), and another on the self-determination theory (Jeno et al., 2017) which, as seen previously, is related to the gamification approach. Nevertheless, 26 percent of the studies do not refer to any theoretical background to support the development or the use of the 
mobile application (Crawford et al., 2016; Noguera et al., 2013; Q. Wu, 2015). This is in line with previous reviews that have shown that a number of studies in mobile learning are not grounded in theory (Bano et al., 2018; Y. Park, 2011).

Moreover, 8o percent of the interventions consist of sessions in which students use the mobile applications during class time. In these sessions, students in the experimental group use the mobile application in class, whereas students in the control group follow a classic lesson related, or not, to the educational content of the app (Ahmed \& Parsons, 2013; Briz-Ponce et al., 2016; Diliberto-Macaluso \& Hughes, 2016; Jeno et al., 2017; Jou et al., 2016; Kiger et al., 2012; Ling et al., 2014; Noguera et al., 2013; Yang et al., 2013; Yoo \& Lee, 2015). In the remaining 20 percent, students use the app in an authentic context, whether it is for acquiring fauna and flora knowledge at the park (Crawford et al., 2016) or for learning English vocabulary about animals in the zoo (Sandberg et al., 2011).

Finally, we can conclude that there is no agreement on the duration of the intervention, as 53\% of the experiments used just one session (Ahmed \& Parsons, 2013; Briz-Ponce et al., 2016; Jeno et al., 2017; Jou et al., 2016; Ling et al., 2014; F. Martin \& Ertzberger, 2013; Yang et al., 2013), whereas 26\% run for several weeks and 6\% delivered as an entire course (Kiger et al., 2012; Nickerson et al., 2017; Sandberg et al., 2011; Yoo \& Lee, 2015). At any rate, one session interventions appear to be sufficient for testing the effectiveness of the mobile learning apps.

Considering previous research, we can assume that mobile learning interventions are effective for educational purposes. However, as far as we know, in the case of online risks and online safety, and more specifically, in the case of contact with strangers, only prototypes of apps have been developed, but there have been no experiments to check their effectiveness (Fan, M., Liyue, Y., \& Bowler, 2016; Hswen, Rubenzahl, \& Bickham, 2014; Singh, Ng, Yap, Husin, \& Malim, 2017). Consequently, further research in this area is needed with experiments checking the effectiveness of these tools. 
Table 15.

Review of previous app interventions

\begin{tabular}{|c|c|c|c|c|}
\hline Study & $\begin{array}{l}\text { Topic and characteristics of the } \\
\text { intervention }\end{array}$ & $\begin{array}{l}\text { Theoretical } \\
\text { background }\end{array}$ & $\begin{array}{l}\text { Sample, study design, duration and } \\
\text { measurement }\end{array}$ & Results \\
\hline $\begin{array}{l}\text { (Ahmed \& } \\
\text { Parsons, } \\
\text { 2013) }\end{array}$ & $\begin{array}{l}\text { Science } \\
\text { ThinknLearn. Four main } \\
\text { components: Knowledge Testing, } \\
\text { Learning, Prediction \& Selection, and } \\
\text { Observation \& Measurement. }\end{array}$ & $\begin{array}{l}\text { Abductive Inquiry } \\
\text { Model (AIM) }\end{array}$ & $\begin{array}{l}161 \text { students in high school } \\
\text { One control (classic class) and one } \\
\text { experimental group (app in class) } \\
\text { One session } \\
\text { Pre-test and several post-tests: } \\
\text { knowledge in science. }\end{array}$ & $\begin{array}{l}\text { Experimental group } \\
\text { gained more knowledge } \\
\text { in science. }\end{array}$ \\
\hline $\begin{array}{l}\text { (Briz- } \\
\text { Ponce et } \\
\text { al., 2016) }\end{array}$ & $\begin{array}{l}\text { Anatomy } \\
\text { Brain System 3D: This app allows } \\
\text { students to learn about the structure } \\
\text { and function of the human brain by } \\
\text { interacting with high-resolution } \\
\text { rotating } 3 \mathrm{D} \text { images in real time. }\end{array}$ & Mobile learning & $\begin{array}{l}30 \text { medical students ( } 18-25 \text { years) } \\
\text { One control (classic class) and one } \\
\text { experimental group (app in class) } \\
\text { One session } \\
\text { Pre-test and post-test: knowledge } \\
\text { about anatomy. Content quality, } \\
\text { navigation, credibility, design and } \\
\text { security and privacy. }\end{array}$ & $\begin{array}{l}\text { The performance of the } \\
\text { learners was better } \\
\text { using the app as a } \\
\text { supportive tool than } \\
\text { using the traditional } \\
\text { methods. }\end{array}$ \\
\hline
\end{tabular}




\begin{tabular}{|c|c|c|c|c|}
\hline Study & $\begin{array}{l}\text { Topic and characteristics of the } \\
\text { intervention }\end{array}$ & $\begin{array}{l}\text { Theoretical } \\
\text { background }\end{array}$ & $\begin{array}{l}\text { Sample, study design, duration and } \\
\text { measurement }\end{array}$ & Results \\
\hline $\begin{array}{l}\text { (Crawford } \\
\text { et al., 2016) }\end{array}$ & $\begin{array}{l}\text { Engagement with nature } \\
\text { Agents of nature: this highlights the } \\
\text { flora, fauna, and ecology of the park. } \\
\text { It allows an avatar to be selected } \\
\text { which interacts with other cartoon } \\
\text { animals. Users can accept challenges } \\
\text { associated with different locations in } \\
\text { the park. }\end{array}$ & - & $\begin{array}{l}747 \text { children (9-14 years) } \\
\text { One day } \\
\text { One control (paper map) and two } \\
\text { experimental groups (mobile app } \\
\text { and park educator) } \\
\text { Pre-test: Connection to nature. } \\
\text { Post-test: Connection to nature, fun, } \\
\text { attitude toward the park and park } \\
\text { content knowledge. }\end{array}$ & $\begin{array}{l}\text { There were no } \\
\text { differences in the } \\
\text { connection to nature, } \\
\text { but children who used } \\
\text { the app had more fun. }\end{array}$ \\
\hline $\begin{array}{l}\text { (Diliberto- } \\
\text { Macaluso \& } \\
\text { Hughes, } \\
\text { 2016) }\end{array}$ & $\begin{array}{l}\text { Introduction to psychology } \\
\text { Interactive 3-D Brain app: This is } \\
\text { interactive and allows the user to } \\
\text { rotate the brain and zoom around } \\
\text { brain structures in } 3 \mathrm{D} \text {. It also } \\
\text { contains learning modules about case } \\
\text { studies, cognitive disorders, damage, } \\
\text { associated functions and brief } \\
\text { abstracts and links to research. }\end{array}$ & - & $\begin{array}{l}54 \text { undergraduate students } \\
\text { Three sessions } \\
\text { One control (textbook) and one } \\
\text { experimental group (app) } \\
\text { Pre-test and post-test: performance }\end{array}$ & $\begin{array}{l}\text { The increase in } \\
\text { performance was } \\
\text { significantly greater on } \\
\text { the multiple choice and } \\
\text { composite measures, } \\
\text { but not on labelling, for } \\
\text { the app students. }\end{array}$ \\
\hline $\begin{array}{l}\text { (Jeno et al., } \\
\text { 2017) }\end{array}$ & $\begin{array}{l}\text { Identification of species } \\
\text { ArtsApp: This allows students to } \\
\text { identify species, contains pictures of } \\
\text { the characteristics of the species and } \\
\text { textual descriptions, and keeps track } \\
\text { of the progress of the student. }\end{array}$ & $\begin{array}{l}\text { Self- } \\
\text { Determination } \\
\text { Theory (SDT) }\end{array}$ & $\begin{array}{l}71 \text { biology students (21-22 years) } \\
\text { One session } \\
\text { One control (textbook) and one } \\
\text { experimental group (app) } \\
\text { Post-test: students' intrinsic } \\
\text { motivation, perceived competence, } \\
\text { and achievement }\end{array}$ & $\begin{array}{l}\text { App students obtained } \\
\text { higher achievement } \\
\text { scores, perceived } \\
\text { competence, and } \\
\text { intrinsic motivation } \\
\text { scores. }\end{array}$ \\
\hline
\end{tabular}




\begin{tabular}{|c|c|c|c|c|}
\hline Study & $\begin{array}{l}\text { Topic and characteristics of the } \\
\text { intervention }\end{array}$ & $\begin{array}{l}\text { Theoretical } \\
\text { background }\end{array}$ & $\begin{array}{l}\text { Sample, study design, duration and } \\
\text { measurement }\end{array}$ & Results \\
\hline $\begin{array}{l}\text { (Jou et al., } \\
2016 \text { ) }\end{array}$ & $\begin{array}{l}\text { Engineering education } \\
\text { IM2Learn: This includes science } \\
\text { concepts, test item bank, course } \\
\text { database, knowledge database, and } \\
\text { user profile database. }\end{array}$ & $\begin{array}{l}\text { Problem-based } \\
\text { Learning (PBL) }\end{array}$ & $\begin{array}{l}87 \text { university students } \\
\text { One session } \\
\text { One control (nothing) and one } \\
\text { experimental group (app) } \\
\text { Pre- and post-learning tests, } \\
\text { students' cognitive load, learning } \\
\text { attitude and reception. }\end{array}$ & $\begin{array}{l}\text { App students achieved } \\
\text { significant } \\
\text { improvements in } \\
\text { learning effectiveness } \\
\text { and attitude. There } \\
\text { were no differences in } \\
\text { the cognitive load } \\
\text { results. }\end{array}$ \\
\hline $\begin{array}{l}\text { (Kiger et } \\
\text { al., 2012) }\end{array}$ & $\begin{array}{l}\text { Maths } \\
\text { Ten math apps were selected based } \\
\text { on several criteria: curriculum } \\
\text { alignment, authentic skill practice, } \\
\text { operational ease, and attractiveness } \\
\text { to students. }\end{array}$ & Mobile learning & $\begin{array}{l}87 \text { students in } 3^{\text {rd }} \text { grade } \\
9 \text { weeks } \\
\text { One control (classic lesson) and one } \\
\text { experimental group (iPod with } 10 \\
\text { apps) } \\
\text { Post-test: multiplication. }\end{array}$ & $\begin{array}{l}\text { Students in the } \\
\text { experimental condition } \\
\text { outperformed the other } \\
\text { students on the } \\
\text { multiplication test. }\end{array}$ \\
\hline $\begin{array}{l}\text { (Ling et al., } \\
\text { 2014) }\end{array}$ & $\begin{array}{l}\text { Statistical Concepts } \\
\text { Learn-Statistics: This provides real- } \\
\text { time and interactive feedback to the } \\
\text { user. }\end{array}$ & $\begin{array}{l}\text { An Integrative } \\
\text { Conceptual } \\
\text { Model of } \\
\text { Learning Bloom's } \\
\text { Taxonomy }\end{array}$ & $\begin{array}{l}26 \text { college students ( } \mathrm{M=20.27} \text { years) } \\
\text { One session } \\
\text { One control (classic lesson) and one } \\
\text { experimental group (app) } \\
\text { Comprehension quiz score. }\end{array}$ & $\begin{array}{l}\text { The app group out- } \\
\text { performed the control } \\
\text { group on the } \\
\text { comprehension quiz. }\end{array}$ \\
\hline
\end{tabular}




\begin{tabular}{|c|c|c|c|c|}
\hline Study & $\begin{array}{l}\text { Topic and characteristics of the } \\
\text { intervention }\end{array}$ & $\begin{array}{l}\text { Theoretical } \\
\text { background }\end{array}$ & $\begin{array}{l}\text { Sample, study design, duration and } \\
\text { measurement }\end{array}$ & Results \\
\hline \multirow{4}{*}{$\begin{array}{l}\text { (F. Martin } \\
\& \\
\text { Ertzberger, } \\
\text { 2013) }\end{array}$} & \multirow{4}{*}{$\begin{array}{l}\text { Art } \\
\text { Lectora Inspire: The art lesson } \\
\text { incorporated information on five } \\
\text { different paintings. For each painting, } \\
\text { the app provided information about } \\
\text { the artist, the artwork, the medium } \\
\text { and style. }\end{array}$} & \multirow{4}{*}{$\begin{array}{l}\text { Here and now } \\
\text { learning }\end{array}$} & $\begin{array}{l}109 \text { undergraduate students (18-22 } \\
\text { years) }\end{array}$ & \multirow{4}{*}{$\begin{array}{l}\text { The CBI treatment } \\
\text { scored higher than the } \\
\text { iPad and iPod } \\
\text { treatments. The iPad } \\
\text { group had the highest } \\
\text { attitude scores, whereas } \\
\text { the CBI treatment had } \\
\text { the lowest scores in the } \\
\text { attitude survey. }\end{array}$} \\
\hline & & & One session & \\
\hline & & & $\begin{array}{l}\text { One control (computer based } \\
\text { instruction CBI) and two } \\
\text { experimental groups (app with iPad, } \\
\text { app with iPod) }\end{array}$ & \\
\hline & & & $\begin{array}{l}\text { Pre-test and post-test: knowledge. } \\
\text { Attitude survey. }\end{array}$ & \\
\hline
\end{tabular}

Business communication

Schoology: Students were provided

$\begin{array}{ll}\text { (Nickerson } & \text { with a series of individual and group } \\ \text { et al., 2017) } & \text { tasks to complete online, including }\end{array}$

discussion forums, digital

storytelling, and video creation tasks.

Attitude survey.

\section{3 university students}

One course

One control (nothing) and two

experimental groups (mobile

learning and conventional group)

Pre-test and post-test: knowledge and comprehension of business

communication concepts

76 students of physiotherapy

Two practical lesson of 5 h each

(Noguera Manual therapy

et al., 2013） 3D mobile application

One control (classic lesson) and one

experimental group (app)

There was no difference

between conventional

and mobile learning

approaches.

Pre-test and post-test: anatomical

knowledge

\section{effective than the}

classic lesson. 


\begin{tabular}{|c|c|c|c|c|}
\hline Study & $\begin{array}{l}\text { Topic and characteristics of the } \\
\text { intervention }\end{array}$ & $\begin{array}{l}\text { Theoretical } \\
\text { background }\end{array}$ & $\begin{array}{l}\text { Sample, study design, duration and } \\
\text { measurement }\end{array}$ & Results \\
\hline $\begin{array}{l}\text { (Q. Wu, } \\
\text { 2015) }\end{array}$ & $\begin{array}{l}\text { English vocabulary } \\
\text { Word Learning-CET6: This contains a } \\
\text { 1,274 word database and lets the } \\
\text { students create sample tests. }\end{array}$ & - & $\begin{array}{l}70 \text { medical school students } \\
55 \text { days } \\
\text { One control (pushing messages to } \\
\text { encourage them to study) and one } \\
\text { experimental group (app) }\end{array}$ & $\begin{array}{l}\text { The app group } \\
\text { remembered more } \\
\text { words. }\end{array}$ \\
\hline $\begin{array}{l}\text { (Sandberg } \\
\text { et al., 2011) }\end{array}$ & $\begin{array}{l}\text { English vocabulary } \\
\text { The MEL-application contains five } \\
\text { different game types: multiple choice } \\
\text { quiz, spelling quiz, memory game, } \\
\text { Yes or No game, and } \\
\text { jigsaw puzzle. }\end{array}$ & $\begin{array}{l}\text { Constructivism } \\
\text { and mobile } \\
\text { learning }\end{array}$ & $\begin{array}{l}\text { English vocabulary test. } \\
75 \text { students (8-10 years) in } 5^{\text {th }} \text { grade } \\
\text { Two weeks } \\
\text { One control group (classic lesson) } \\
\text { and two experimental groups (app } \\
\text { during a visit to the zoo and app in } \\
\text { the visit with participants keeping } \\
\text { the app for two weeks) } \\
\text { Pre-test and post-test: mastery of a } \\
\text { set of targeted English words. }\end{array}$ & $\begin{array}{l}\text { The participants that } \\
\text { kept the app scored } \\
\text { significantly higher on } \\
\text { post-test than the other } \\
\text { conditions. However, if } \\
\text { we consider the } \\
\text { learning time, there are } \\
\text { no differences between } \\
\text { conditions. }\end{array}$ \\
\hline $\begin{array}{l}\text { (Yang et } \\
\text { al., 2013) }\end{array}$ & $\begin{array}{l}\text { Chinese poetry } \\
\text { Ubiquitous Poetry Learning Scheme } \\
\text { includes: presentation of poem } \\
\text { content, annotations, explanation, } \\
\text { and multimedia resources. }\end{array}$ & $\begin{array}{l}\text { Multimedia } \\
\text { learning }\end{array}$ & $\begin{array}{l}64 \text { students in } 7 \text { th grade } \\
\text { One session } \\
\text { One control (textbook) and one } \\
\text { experimental group (app) } \\
\text { Pre-test: existing knowledge of } \\
\text { Chinese poetry. Post-test: learning } \\
\text { achievements }\end{array}$ & $\begin{array}{l}\text { Learning by using UPLS } \\
\text { is more effective than } \\
\text { conventional learning } \\
\text { in promoting learning } \\
\text { achievement of the } \\
\text { students. }\end{array}$ \\
\hline
\end{tabular}




\begin{tabular}{|c|c|c|c|c|}
\hline Study & $\begin{array}{l}\text { Topic and characteristics of the } \\
\text { intervention }\end{array}$ & $\begin{array}{l}\text { Theoretical } \\
\text { background }\end{array}$ & $\begin{array}{l}\text { Sample, study design, duration and } \\
\text { measurement }\end{array}$ & Results \\
\hline \multirow{5}{*}{$\begin{array}{l}\text { (Yoo \& Lee, } \\
\text { 2015) }\end{array}$} & \multirow{5}{*}{$\begin{array}{l}\text { Cardio-pulmonary assessment } \\
\text { iStethoscope Expert }\end{array}$} & \multirow{5}{*}{ Mobile learning } & 22 nursing students & \multirow{5}{*}{$\begin{array}{l}\text { The app group was only } \\
\text { significantly higher on } \\
\text { the post-test of } \\
\text { knowledge of lung } \\
\text { assessment. }\end{array}$} \\
\hline & & & Five weeks & \\
\hline & & & One control (human patient & \\
\hline & & & $\begin{array}{l}\text { simulator) and one experimental } \\
\text { group (app) }\end{array}$ & \\
\hline & & & $\begin{array}{l}\text { Pre- and post-assessment. Student } \\
\text { satisfaction with their education. }\end{array}$ & \\
\hline
\end{tabular}




\subsection{The Entertainment-Education Strategy}

Entertainment-education (E-E) consists of the intentional design, incorporation and delivery of educational content within entertaining formats (Ayala et al., 2015; W. J. Brown \& Singhal, 1999; Rogers et al., 1999). It is a strategy, rather than a theory of communication, used to disseminate pro-social messages (Singhal \& Rogers, 2002). Accordingly, the objective of this strategy is to increase audience's knowledge about an issue, to change behaviours and to create favourable attitudes towards that issue, for example, a health-related issue (Asbeek Brusse, Fransen, \& Smit, 2015; Igartua, 2011; Singhal, Rogers, \& Brown, 1993b).

The use of entertainment for educational purposes allows the overcoming of limitations of purely informational and "boredom-educational" programmes, that have been shown to be ineffective (W. J. Brown \& Singhal, 1999; Brusse, Fransen, \& Smit, 2017; Singhal, Rogers, \& Brown, 1993a). Consequently, these educational messages are incorporated into entertaining formats, such as television series, music videos, comic books or radio soap operas (W. J. Brown \& Singhal, 1999; Igartua, 2017; Khalid \& Ahmed, 2014). Therefore, E-E products should be entertaining and enjoyable by definition (van Leeuwen, Renes, \& Leeuwis, 2013). What differentiates entertainment-education from pure entertainment is that entertainment-education products are designed to promote pro-social beliefs and values among a large audience. Moreover, it has a theoretical base and makes a clear distinction between good and bad behaviours in order to encourage the audience to imitate positive role models (Khalid \& Ahmed, 2014). Although they have several advantages, some drawbacks of these E-E initiatives are that they are "generally more complex to produce, require a greater degree of planning and analysis than entertainment programmes and present difficult ethical choices" (W. J. Brown \& Singhal, 1999, p. 265). 
The first examples of entertainment-education are as ancient as the art of storytelling if we consider that mythological chronicles were used to teach moral principles of life. Moreover, through history, folk media, such as music, dance or tales, have been used not only for recreation, but also for instructional purposes (Khalid \& Ahmed, 2014). Consequently, they are part of people's informal education (W. J. Brown \& Singhal, 1999).

Nevertheless, "the earliest well known illustration of the education entertainment strategy can be traced to the radio drama The Lawsons" (Khalid \& Ahmed, 2014, p. 73), followed by The Arches. This last one is a radio soap opera broadcast on the $\mathrm{BBC}$ which promotes agricultural innovations among farmers through an entertaining story line (W. J. Brown \& Singhal, 1999). From that moment on, this educational and communication strategy has been popular among international health promotion programme planners (Hether, Huang, Beck, Murphy, \& Valente, 2008). Therefore, in the late nineties there were about 75 entertainmenteducation programmes in progress in more than 40 countries (W. J. Brown \& Singhal, 1999). Nowadays, however, we can cite more than 200 entertainment-education initiatives in 50 countries in Africa, Asia, Europe and the Americas (Igartua, 2011).

Consequently, this strategy has been incorporated into a wide range of entertaining products, such as television series (Hether et al., 2008; Igartua \& Vega Casanova, 2016), radio soap operas (Rogers et al., 1999; Vaughan \& Rogers, 200o) and magazines (Hust et al., 2017), for covering different health or social issues, such as AIDS prevention, sexual assault prevention and healthy eating (Ayala et al., 2015; Hether et al., 2008; Hust et al., 2017; Igartua, Cheng, \& Lopes, 2003; Khalid \& Ahmed, 2014; Vaughan, Rogers, Singhal, \& Swalehe, 200o), and in lots of different countries, such as Peru, Colombia, South Africa, the United States, Jamaica or Tanzania (W. J. Brown \& Singhal, 1999; Forster, Allem, Mendez, Qazi, \& Unger, 2016; Hether et al., 
2008; Hust et al., 2017; Igartua \& Vega Casanova, 2016; Rogers et al., 1999; Y. J. Shin, Miller-Day, Hecht, \& Krieger, 2017).

Accordingly, research has supported the effectiveness of integrating educational messages into entertainment products for preventing sexual assault (Hust et al., 2017), increasing the adoption of family planning methods (Rogers et al., 1999; Vaughan \& Rogers, 2000), preventing youth substance (alcohol and drugs) abuse (Y. J. Shin et al., 2017; van Leeuwen et al., 2013), increasing viewers' knowledge about breast cancer (Hether et al., 2008; Wilkin et al., 2007) and improving awareness and knowledge about kidney disease, the transplantation process and important aspects of self-care in patients with end-stage renal disease (Forster et al., 2016), among others. Moreover, a meta-analysis of studies on the impact of entertainment-education on health communication demonstrated that it had a significant, although small, effect $(r=.12, p<.001)$ on persuasion (F. Shen \& Han, 2014). At any rate, this effect is greater than the effect of traditional health campaigns, and it shows that the entertainmenteducation strategy is more effective than traditional campaigns for health issues (Igartua, 2017).

From the beginning, the entertainment-education strategy has been grounded in the social learning or social cognitive theory (Forster et al., 2016; MoyerGusé, 2008). According to this well-known theory, developed by Bandura, knowledge, attitudes and behaviours can be developed and influenced by direct experience or by observing and imitating the overt behaviour of other individuals who serve as role models (de Graaf \& van Leeuwen, 2017; Hether et al., 2008; Rogers et al., 1999). This process is reinforced while observing the consequences of the behaviour; beneficial consequences will positively reinforce the behaviour, whereas negative consequences will negatively reinforce the behaviour (Vaughan \& Rogers, 200o).

Accordingly, characters in the entertainment-education product serve as role models that demonstrate how to perform a desirable behaviour (Rogers et al., 1999; Y. 
RISKS OF INTERACTIVE COMMUNICATION IN ADOLESCENTS.

DIGITAL LITERACY DIAGNOSIS AND INTERVENTION

J. Shin et al., 2017). Therefore, these characters would perform the recommended behaviour, such as using a condom to prevent HIV (Vaughan et al., 200o), and that would result in behaviour change in the audience (Y. J. Shin et al., 2017). Consequently, "it is important to make sure that positive role models support all of the values important to the message" (Khalid \& Ahmed, 2014, p. 78). Moreover, it is also important to show the consequences derived from these behaviours. Provided that there are positive consequences (e.g., good health from regular exercising), the recipient will be more likely to copy this behaviour (de Graaf \& van Leeuwen, 2017).

Even though the entertainment-education strategy has been found to be effective with different types of media content, such as TV medical dramas (Hether et al., 2008) or magazines (Hust et al., 2017), the most well-known interventions have been conducted through telenovelas or soap operas (Singhal, Obregon, \& Rogers, 1994).

Simplemente María was the first example of a pro-social telenovela (Khalid \& Ahmed, 2014). Created in Peru in 1969, it tells the story of a migrant single mother who decides to enrol in adult literacy classes and to learn how to sew. She became a fashion designer and, at the end of the soap opera, she owns a successful clothing boutique (Singhal et al., 1994). Therefore, she succeeded in achieving upward social mobility (Igartua, 2011; Singhal et al., 1993b). Although there was no quantitative research and the effects of this Peruvian telenovela on its audience were unplanned and unintentional, during its broadcast thousands of women decided, like María, to enrol in adult literacy and sewing classes (Singhal et al., 1994, 1993b). Thus, this pioneering experience demonstrated that soap operas could convey educational messages (Singhal et al., 1993b).

Following this success, Miguel Sabido, a writer, producer and director in Mexico, created an entertainment-education methodology and produced eleven prosocial telenovelas (Khalid \& Ahmed, 2014). The aim of these productions was to 
educate the audience about values, beliefs and practices intended to advance development in the country, such as sexual responsibility among teenagers and adult literacy (W. J. Brown \& Singhal, 1999; Khalid \& Ahmed, 2014). These telenovelas were commercial successes with high audience ratings and they were successful in meeting their educational aims (Singhal et al., 1994).

The success of these productions inspired other countries to produce entertainment-education soap operas (W. J. Brown \& Singhal, 1999). Consequently, telenovelas have been commonly and successfully used for conveying educational messages and promoting behaviour changes, especially among Hispanic audiences and in developing countries (W. J. Brown \& Singhal, 1999; Forster et al., 2016; Singhal et al., 1993b; Wilkin et al., 2007).

Finally, one unique aspect of entertainment-education is its narrative format (Asbeek Brusse et al., 2015; Moyer-Gusé, 2008). In this sense, we can define a narrative as "a story or series of events that has an identifiable beginning, middle, and end, during which characters may encounter and then resolve a crisis or crises" (Fitzgerald \& Green, 2017, p. 50). The narrative structure facilitates transportation or narration involvement and identification with the characters, two key mechanisms underlying narrative persuasion (Brusse et al., 2017; Fitzgerald \& Green, 2017; Moyer-Gusé, 2008), as we shall see.

In the next section we will analyse these mechanisms that explain the power of narratives in promoting positive attitudes and behaviours, since the social cognitive theory may not be sufficient to explain the effects of entertainment-education (Slater \& Rouner, 2002). For that reason, the study of narrative persuasion has been incorporated into entertainment-education research (Igartua, 2011), which has led to the incorporation of some theoretical models in this field: the extended elaboration likelihood model (Slater \& Rouner, 2002), the transportation-imagery model (Green \& Brock, 2002), and the entertainment overcoming resistance model (Moyer-Gusé, 
RISKS OF INTERACTIVE COMMUNICATION IN ADOLESCENTS.

DIGITAL LITERACY DIAGNOSIS AND INTERVENTION

2008). Accordingly, in the next section we will review these three theoretical models and the mechanisms that explain narrative persuasion.

\subsection{The Power of Narrative and its Explanatory Mechanisms.}

Research has demonstrated that narratives have significant effects on beliefs, attitudes, intentions, and behaviours (Braddock \& Dillard, 2016). These effects have been traditionally addressed in narratives in text format (Green, Brock, \& Kaufman, 2004; Igartua, Guerrero-Martín, Cachón-Ramón, \& Rodríguez-de-Dios, 2018; Igartua, Wojcieszak, Cachón-Ramón, \& Guerrero-Martín, 2017; Stavrositu \& Kim, 2015), audiovisual format (Igartua, 2010; Igartua \& Barrios, 2012; Igartua \& Fiuza, 2018; Igartua \& Frutos, 2017; Igartua \& Lozano, 2011; Igartua \& Vega Casanova, 2016; Murphy, Frank, Chatterjee, \& Baezconde-Garbanati, 2013; Murphy, Frank, Moran, \& Patnoe-Woodley, 2011; L. Shen, Seung, Andersen, \& Mcneal, 2017; van Leeuwen, van den Putte, Renes, \& Leeuwis, 2017) and videogames format (Elson, Breuer, Ivory, \& Quandt, 2014; A. S. Lu et al., 2016; Lyons et al., 2016). In general, studies have shown that the use of narratives, compared to nonnarrative formats, is more effective in changing attitudes, beliefs and behaviours (Murphy et al., 2013). Furthermore, a meta-analysis that examined the effectiveness of narratives in health interventions found that narratives had a significant, but small, impact $(r=.063, p<.01)$ on persuasion (F. Shen, Sheer, \& Li, 2015).

As mentioned earlier, there are three theoretical models that have been widely used in the study of narrative persuasion: the extended elaboration likelihood model (E-ELM), the transportation-imagery model (TIM; Igartua, 2011; Igartua \& Barrios, 2012) and the entertainment overcoming resistance model (EORM; MoyerGusé, 2008; Moyer-Gusé \& Nabi, 2010).

Firstly, the E-ELM postulates that entertainment-education products attract audiences because they are compelling drama. Consequently, a degree of engagement 
with the narrative (absorption in the narrative) and a degree of identification with the characters are essential as they enhance the persuasive effects of the entertainmenteducation content (Slater \& Rouner, 2002). According to this model, identification with characters depends upon absorption in the narrative, which is an essential mediating variable that reduces counterargument and reactance (Moyer-Gusé, 2008; F. Shen \& Han, 2014; Slater \& Rouner, 2002). In fact, counterargument, which means having negative or critical thoughts about the persuasive argument (Igartua \& Barrios, 2012), would be incompatible with absorption in the narrative. Consequently, by impeding counterargument, narratives would be effective in influencing beliefs, attitudes and behaviours of individuals (Moyer-Gusé, 2008; Slater \& Rouner, 2002). With reference to reactance, the use of narratives reduces the reactance that is often evoked by persuasive messages as readers do not expect to be intentionally influenced by entertainment content (Fitzgerald \& Green, 2017; Moyer-Gusé, 2008).

Secondly, the TIM establishes that, during narrative transportation, imagery, affect and attentional focus, that is, the mental capacities of the individual, are focused on the story. This mental state of cognitive, emotional and imagery involvement in the narrative explains its persuasive effect. The experience of being taken into the narrative world, and leaving the real world behind, supposes that the individual can easily assume some beliefs implied by the story (de Graaf \& van Leeuwen, 2017; Green \& Brock, 2002; Green et al., 2004). In this way, this model explains the persuasive effects of fictional narratives through the state of narrative transportation (Igartua, 2011).

Thirdly, the EORM was developed for explaining and understanding the process through which entertainment-education narratives impact on the population (Igartua, 2017). This model highlights the relevance of narrative involvement and involvement with characters in the impact of entertainment-education (Moyer-Gusé, 2008). According to its author, narrative involvement refers to narrative transportation; whereas involvement with characters refers to identification, wishful 
RISKS OF INTERACTIVE COMMUNICATION IN ADOLESCENTS.

DIGITAL LITERACY DIAGNOSIS AND INTERVENTION

identification, similarity, parasocial interaction, and liking (Igartua, Wojcieszak, \& Kim, 2018; Moyer-Gusé, 2008). Furthermore, this model aims to explain how entertainment-education initiatives can overcome different forms of resistance (Moyer-Gusé \& Nabi, 2010). Consequently, it analyses what features of entertainment media, such as the narrative structure, enjoyment and perceived similarity, that facilitate involvement with characters and/or narrative involvement explain persuasive effects of entertainment-education products (Moyer-Gusé, 2008).

In view of the above, and according to the theoretical models presented, there are two main mechanisms that explain and predict the effects of narrative persuasion since they cause a decline in critical thinking, criticism and counterargument during exposure to the narrative: narrative transportation and identification with characters (de Graaf \& van Leeuwen, 2017; Igartua \& Vega Casanova, 2016; Moyer-Gusé, 2008; L. Shen et al., 2017; Slater \& Rouner, 2002).

First, narrative transportation (also known as narrative involvement, absorption, engagement or immersion) refers to the experience of being completely immersed in a story, so that we forget about the real world and our immediate environment (Green \& Brock, 2000; Green et al., 2004; Moyer-Gusé, 2008). That is, the reader or spectator takes a mental journey into the world of the narrative and this involves emotional, affective and cognitive processes (Appel \& Richter, 2007; Fitzgerald \& Green, 2017). This transportation has been shown to be a mediator of persuasive influence (Murphy et al., 2013) and has been associated with enjoyment and positive affect (Green et al., 2004).

As mentioned previously, narrative transportation has been shown to reduce the critical evaluation of content and, as such, counterargument, which leads to message acceptance and the occurrence of persuasive effects (Appel \& Richter, 2007; de Graaf \& van Leeuwen, 2017; Fitzgerald \& Green, 2017; Slater \& Rouner, 2002). Consequently, this circumstance of being absorbed by the narrative, and the effects 
derived from this is what differentiates the entertainment-education strategy from purely persuasive messages (Moyer-Gusé, 2008). In general, the greater the narrative transportation, the more likely the reader or the spectator is to change their beliefs, behaviours and behavioural intentions to be more consistent with those that are shown or promoted in the narrative (Fitzgerald \& Green, 2017; Murphy et al., 2013, 2011).

In this sense, narrative transportation can be facilitated by increasing the familiarity of the reader with the material in a narrative. Similarly, reminders of personal experiences that relate to those in the narrative also seem to be important in determining narrative impact (Fitzgerald \& Green, 2017). That is, if we aim to construct a narrative for adolescents, one way of increasing their familiarity and connection with previous experiences, and as such, narrative transportation and impact, would be to set the story in a high school.

Secondly, according to Moyer-Gusé (2008), involvement with characters is made up of five constructs: identification with characters, wishful identification, perceived similarity, parasocial interaction and liking. All of these refer to viewers' interaction with fictional characters (Murphy et al., 2011). Identification refers to an emotional and cognitive process in which the individual takes on the role of the character (Cohen, 2001; Igartua \& Barrios, 2012). In wishful identification, the individual desires to be like the character. Moreover, perceived similarity refers to the degree to which the person perceives that they are similar to the character (because of variables such as physical attributes, beliefs or demographic variables). Parasocial interaction refers to the interaction between the individual and the character and, finally, liking refers to positive evaluations of the character (Moyer-Gusé, 2008).

Focusing on this identification, it has been found that this predicts beliefs and attitudinal changes (de Graaf, Hoeken, Sanders, \& Beentjes, 2012; Fitzgerald \& Green, 2017; Igartua, 2010; Igartua \& Barrios, 2012; Igartua \& Frutos, 2017; Igartua \& Vega 
Casanova, 2016; Moyer-Gusé, Chung, \& Jain, 2011; Murphy et al., 2013). According to Cohen (2001), identification with characters is composed of four dimensions: emotional empathy (sharing feelings with the character, that is, feeling what the character feels), cognitive empathy (sharing the character's perspective and adopting their point of view), motivation (internalising the character's goals) and the sensation of becoming the character (losing of self-awareness). Nonetheless, the model of identification with characters proposed and validated by Igartua and Barrios (2012) includes only three dimensions: emotional empathy (feeling what the characters feel), cognitive empathy (adopting the point of view of the character or putting oneself in its place) and the sensation of becoming the character (temporal loss of self-awareness and imagining the story as being one of the characters). At any rate, identification focuses on one particular character and not on the storyline overall and includes three other dimensions apart from transportation or loss of self-awareness (Moyer-Gusé, 2008).

Therefore, even though identification with characters and narrative transportation are usually highly correlated and both are related to engagement with the narrative, as we can see, they are different immersive experiences (Cohen \& TalOr, 2017; Fitzgerald \& Green, 2017). In brief, identification with a character supposes that the reader or spectator experience the narrative through the perspective of this character and, consequently, they adopt their goals and motivations. Nonetheless, transportation refers to a more general immersion or absorption in the storyline (Fitzgerald \& Green, 2017). Consequently, these mechanisms are influenced by different factors: narrative transportation tends to be affected by factors related to the narrative, such as suspense or familiarity with the material, and identification with the characters, with factors related to these characters, such as how good they seem (Cohen \& Tal-Or, 2017) or how similar they are to the audience (Igartua, Wojcieszak, et al., 2018).

$$
\sim 136 \sim
$$


At any rate, as with narrative transportation, identification with characters reduces the capacity of individuals to criticise and counter argue against the persuasive content presented in the narrative (Igartua \& Barrios, 2012; Moyer-Gusé et al., 2011; Moyer-Gusé \& Nabi, 2010; Slater \& Rouner, 2002). Therefore, the greater the identification with the character, the more likely the reader or spectator is to change their beliefs and behaviours to be more consistent with those that are displayed or promoted by the character.

It is generally assumed that similarity is related to identification with characters (Cohen \& Tal-Or, 2017). In this sense, "similarity describes a process through which the person who is exposed to a narrative message assesses to what extent he or she shares certain traits with the protagonist" (Igartua et al., 2017, p. 1089). This similarity can be based on objective features (e.g., age, gender or nationality) or psychological or subjective (e.g., values and experiences) aspects (Igartua, Wojcieszak, et al., 2018). Concordantly, it has been thought that individuals would have greater levels of identification with characters of the same demographic characteristics (Igartua \& Fiuza, 2018). Following this line, research has found that children identified more strongly with characters of their own gender (Jose \& Brewer, 1984) and that students had higher levels of identification with characters that had completed a similar study programme to the one they were following (Hoeken, Kolthoff, \& Sanders, 2016). Other studies have found that similarity in terms of nationality had no direct effect on identification, but had an indirect effect on it by means of negative emotions (Igartua \& Fiuza, 2018). However, research has also found that demographic similarity, such as sharing age, sex or nationality with the character, has no significant effect on the level of identification with the character (M. Chen, Bell, \& Taylor, 2017; Cohen, Weimann-Saks, \& Mazor-Tregerman, 2017; Tukachinsky, 2014). Therefore, as the role of demographic similarity in increasing identification is not clear, it is preferable to create characters with whom the target audience can identify. In some cases this may involve creating more than one version of the narrative (Murphy et al., 2013). 
RISKS OF INTERACTIVE COMMUNICATION IN ADOLESCENTS.

DIGITAL LITERACY DIAGNOSIS AND INTERVENTION

It has also been argued that another possible source of influence on the level of identification with the character is the story's point of view, that is, use of first over third person narratives (Cohen \& Tal-Or, 2017; Nan, Dahlstrom, Richards, \& Rangarajan, 2015). However, there is no agreement on this as some studies have found no relationship (Christy, 2017) and others have found that the use of first person narratives results in greater identification (de Graaf et al., 2012). Moreover, a study of health narratives showing the negative effects of drugs found that, for those who were autobiographically similar to the character, the first person narrative produced great narrative transportation (H. K. Kim \& Shapiro, 2016).

At any rate, even if it is not clear if the person of the narrative actually has an impact upon narrative transportation or identification with the character, it has been shown to influence attitudes and behaviours (Christy, 2017). Accordingly, research has generally found that the first person is more effective for inducing attitude and behaviour changes (M. Chen, Bell, \& Taylor, 2016; de Graaf et al., 2012; H. K. Kim \& Shapiro, 2016; Nan et al., 2015; Nan, Futerfas, \& Ma, 2017). Therefore, research suggests that first person narratives are more effective in achieving a persuasive effect.

Consequently, as we have seen above, the use of the entertainment-education strategy and, subsequently, the use of narrative formats, can enhance narrative transportation and identification with characters. These mechanisms, in turn, reduce reactance and counterargument. As a result, belief, attitude and behaviour changes are facilitated. In brief, the use of narratives (preferably first person narratives) can be an effective way to improve knowledge about an issue and to enhance attitude and behaviour changes.

\subsection{Narrative Persuasion in Mobile Learning}

Throughout the previous sections we have reviewed different theories or strategies that have demonstrated their effectiveness for knowledge dissemination: the mobile 
learning theory, the entertainment-education strategy and the narrative persuasion theory. At this stage, we are concerned with whether the combined use of these strategies and theories would be an effective way of reaching a learning objective. Is it possible to incorporate narrative persuasion into mobile applications developed with a learning objective, that is, into mobile learning?

The concept of narrative learning environments, which refers to technologymediated learning environments that use stories to facilitate learning, has been recently introduced (Dettori, 2007). Nevertheless, research in this field is still scarce. Most of the studies on the use of narratives in digital media have focused on interactive narratives (Downs et al., 2004; Hand \& Varan, 2009; Paiva et al., 2005; Riedl, 2010; Sangalang, Johnson, \& Ciancio, 2013; Soto-Sanfiel, Aymerich-Franch, \& Ribes Guàrdia, 2010). In this sense, the use of stories that allow readers or spectators to determine the direction of the plot (Green \& Jenkins, 2014) has been found to increase identification with the characters (Soto-Sanfiel et al., 2010) and immersion or transportation (Hand \& Varan, 2009).

However, the focus of our study is on the use of traditional, not interactive, narratives in mobile learning. Regrettably, we have only found one paper with a study protocol for a trial of a narrative-based mobile application for promoting physical activity among breast cancer survivors (Lyons et al., 2016). As far as we know, results of the study have not yet been published.

Accordingly, and as we mentioned before, research on the combined use of narrative persuasion and mobile learning is practically non-existent. Nonetheless, and considering the benefits and the positive outcomes of these approaches separately, it is expected that their combination would have successful outcomes. Therefore, more research is needed in the evaluation of mobile learning applications that include narrative contents. 
RISKS OF INTERACTIVE COMMUNICATION IN ADOLESCENTS.

DIGITAL LITERACY DIAGNOSIS AND INTERVENTION

\subsection{Summary and Conclusions}

In this chapter we have seen different theoretical approaches that have been found to be successful for knowledge dissemination: mobile learning, entertainment-education and narrative persuasion.

First, mobile learning, which consists of the acquisition of knowledge through mobile technology, has come to be widely studied in recent years. As we have seen, to be effective, mobile learning interventions should consider two theoretical bases: constructivism and gamification. Consequently, they should include active and authentic learning activities for increasing the acquisition of knowledge, and game elements for enhancing motivation, engagement and learning. Subsequently, we have reviewed research conducted on mobile learning interventions developed through mobile applications. As we have seen, most of these were successful in promoting learning outcomes. Nevertheless, we could not find studies of mobile applications developed with learning content related to online safety and contact with strangers. Therefore, we called for further research in this field.

Secondly, we also presented an approach to the entertainment-education strategy, which consists of the incorporation of educational content into entertaining formats, such as television series, radio soap operas and music videos. As we saw, this strategy has been found to be effective for conveying educational messages, for increasing audience knowledge about a topic and for promoting positive behaviours. In this sense, and as we mentioned, one essential characteristic of the E-E strategy is its narrative format. Consequently, in the fourth section of this chapter we reviewed the mechanisms that explain the power of narratives in promoting positive attitudes and behaviours: narrative transportation and identification with characters. These mechanisms reduce reactance and counterargument, and as a result, belief, attitude and behaviour changes are facilitated. Therefore, we concluded that the use of 
narratives (preferably, first person narratives) could be an effective way to improve knowledge about an issue and to enhance attitude and behaviour changes.

Finally, to end the present chapter, we reviewed previous literature with the aim of finding out if the incorporation of narrative persuasion into mobile learning presents positive outcomes. Nevertheless, we found that most of the research on this topic is focused on interactive narratives. Therefore, we called for more research on the use of narrative persuasion in mobile learning.

At any rate, as we have seen, the use of both mobile learning and the entertainment-education strategy present many benefits and positive outcomes. Given the absence of mobile learning initiatives for improving adolescents' online safety and the effectiveness of narrative persuasion for promoting positive attitudes and behaviours, we consider that further research should develop and test the effects of using narratives in mobile applications aimed at this target. 

III. EMPIRICAL

RESEARCH 



\section{Chapter 6.}

STUDY 1.

\section{DEVELOPMENT AND}

\section{VALIDATION OF THE DIGITAL LITERACY SCALE 3}

\subsection{Introduction}

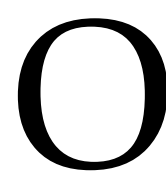

ver the last few years, research related to digital literacy and digital skills has grown exponentially. As we mentioned previously, digital skills are becoming essential in a range of disciplines and professional occupations and in different aspects of people's lives. Moreover, these skills have been proposed as

3 Part of this chapter is published in two publications:

- Rodríguez-de-Dios, I., Igartua, J.-J., \& González-Vázquez, A. (2016). Development and validation of a digital literacy scale for teenagers. In Proceedings of the Fourth International Conference on Technological Ecosystems for Enhancing Multiculturality - TEEM '16 (pp. 1067-1072). New York, New York, USA: ACM Press.

- Rodríguez-de-Dios, I., van Oosten, J. M. F., \& Igartua, J.-J. (2018). A study of the relationship between parental mediation and adolescents' digital skills, online risks and online opportunities. Computers in Human Behavior, 82, 186-198. 
RISKS OF INTERACTIVE COMMUNICATION IN ADOLESCENTS.

DIGITAL LITERACY DIAGNOSIS AND INTERVENTION

a prevention tool against online risks on minors (Eshet-Alkalai, 2004; S.-J. Lee \& Chae, 2012; Sonck et al., 2011).

As we saw in the theoretical background, in order to study people's digital skills, researchers have started to develop digital literacy measures. However, currently existing measures have several limitations, such as not being up to date with the fast changes in technology (Wilson et al., 2015), having a narrow focus on the Internet at the omission of other technological developments (Hargittai \& Hsieh, 2012; S.-J. Lee \& Chae, 2012; Len-Ríos et al., 2016; M.-J. Tsai \& Tsai, 2010) or not having been validated (Gastelú et al., 2015; Li \& Ranieri, 2010; S. Park \& Burford, 2013; Pino Juste \& Soto Carballo, 2010). Others have been validated only among children, adults or young adults, but not among adolescents (Boyaci \& Atalay, 2016; Bunz et al., 2007; Helsper \& Eynon, 2013; Koc \& Barut, 2016; S. Park \& Burford, 2013; Røkenes \& Krumsvik, 2016). Therefore, the main goal of the present study is to develop and validate a Digital Literacy Scale to assess adolescents' digital literacy and its different digital skills.

Moreover, it is important to remember that, based on previous literature (Bawden, 2001; Claro et al., 2012; Eshet-Alkalai \& Chajut, 2009; Gui \& Argentin, 2011; Hargittai, 2008; Helsper \& Eynon, 2013; Koc \& Barut, 2016; S.-J. Lee \& Chae, 2012; Leung \& Lee, 2012a; Livingstone, 2004; Sonck \& de Haan, 2014; Wilson et al., 2015; Zhang \& Zhu, 2016), we consider that digital literacy consists of several specific digital skills that adolescents need to learn in order to function effectively in the digital environment. Therefore, the scale was developed based on research by Area and Pessoa (2012), Shapiro and Hughes (1996), and Cabero, Marín, and Llorente (2012), and bearing in mind the existence of skills.

Five different skills were considered as being part of the broader concept of digital literacy, similar to previous research (Bunz, 2004; Helsper \& Eynon, 2013; S.-J. Lee \& Chae, 2012; Sonck \& de Haan, 2014; Zhang \& Zhu, 2016): technological or instrumental skill (i.e., the ability to effectively use digital technologies), 
communication skill (i.e., the ability to communicate through digital technologies), information skill (i.e., the ability to find information, obtain it, and evaluate its relevance in the digital environment), critical skill (i.e., the ability to critically analyse the information obtained) and security skill (i.e., the ability to use digital technology without risks and dangers).

To develop the scale of digital skills, we built on previous research that has developed lists of dimensions and indicators to measure digital skills (Arnone, Small, \& Reynolds, 2010; Ferrari, 2012; Lau \& Yuen, 2014; Livingstone, Haddon, Görzig, \& Ólafsson, 2011b; Mascheroni \& Ólafsson, 2014; Sonck et al., 2011; van Deursen et al., 2014, 2012). We generated a list of 47 items that were measured with a 5-point Likert scale (1: strongly disagree to 5 : strongly agree) for the five dimensions of digital literacy proposed in the theoretical framework. Since the scale was developed for adolescents, when creating the items we considered that they should be age-appropriate and comprehensible (Görzig, 2012).

Moreover, we used a self-report questionnaire, which is the most frequently used method for measuring digital skills (Kuhlemeier \& Hemker, 2007). In fact, it is an obvious measure for a large sample (Sonck et al., 2012). Some researches argue that, ideally, digital skills should be directly observed in performance tests (Sonck \& de Haan, 2013), but their costliness and time-consumption are strong limitations (van Deursen et al., 2012). Therefore, self-report questionnaires are unquestionably useful for measuring digital skills when we want to deal with large samples in a short time, as in the present study.

After generating the items, we followed three steps to create and validate the Digital Literacy Scale (Sumter, Valkenburg, Baumgartner, Peter, \& van der Hof, 2015). First, we conducted a pilot study to identify difficult words or sentences, to improve the scale and to reduce the number of initial items. Second, we conducted exploratory factor analysis on the first half of the sample and confirmatory factor analysis on the 
RISKS OF INTERACTIVE COMMUNICATION IN ADOLESCENTS.

DIGITAL LITERACY DIAGNOSIS AND INTERVENTION

second half of the sample. Third, we analysed the convergent validity of the scale by looking at the relationships with other variables that were expected to relate to digital skills. Accordingly, a review of the literature shows that there is a positive correlation between high levels of digital literacy and a favourable attitude towards technology (Ainley, Fraillon, Gebhardt, \& Schulz, 2012; Zylka, Christoph, Kroehne, Hartig, \& Goldhammer, 2015), and a negative association with anxiety towards technology (De Wit, Heerwegh, \& Verhoeven, 2014; Durndell \& Haag, 2002; Zylka et al., 2015). Similarly, age is expected to relate to the level of digital literacy, with older students having a higher level than younger students (Appel, 2012; Kuhlemeier \& Hemker, 2007; Mascheroni \& Ólafsson, 2014; Sonck et al., 2011). Likewise, male adolescents tend to report a higher level of digital literacy than female adolescents (Hakkarainen et al., 200o; Kopaiboon, Reungtrakul, \& Wongwanich, 2014; Kuhlemeier \& Hemker, 2007; Mascheroni \& Ólafsson, 2014; Y. J. Park, 2013).

\subsection{Method}

\subsubsection{Pilot Study}

Prior to the main study, a pilot study was conducted with the initial item pool for the Digital Literacy Scale with the aim of improving the scale. These items were administered on a paper-and-pencil questionnaire to 208 students of secondary education 12-17 years of age $(M=14.14, S D=1.44)$ in Spain. Moreover, $52.7 \%$ were girls and $47.3 \%$ were boys.

After a psychometric analysis, we excluded 11 items that had extreme values of skewness and kurtosis (see Table 16). We also identified words that were difficult to understand for respondents (e.g., smartphone and word processor) and excluded another item because the students were not able to understand it (i.e. "I am able to recognise if the information is ideologically biased").

$$
\sim 148 \sim
$$


Table 16.

Items excluded because of extreme values of skewness and kurtosis

\begin{tabular}{|c|c|c|}
\hline Items (I know...) & Skewness & Kurtosis \\
\hline How to download apps to my mobile or tablet without help & -3.23 & 10.51 \\
\hline How to uninstall apps when not liked or needed & -4.18 & 16.88 \\
\hline How to go to a previous page when browsing the Internet & -2.00 & 3.26 \\
\hline $\begin{array}{l}\text { How to upload images, videos or music onto any of my social } \\
\text { media profiles (e.g., Twitter, Facebook, etc.) }\end{array}$ & -2.11 & 3.38 \\
\hline $\begin{array}{l}\text { How to use different tools on the mobile phone to } \\
\text { communicate with others (WhatsApp, email, phone call, } \\
\text { etc) }\end{array}$ & -2.02 & 3.52 \\
\hline Which information I should and shouldn't share online & -4.39 & 22.09 \\
\hline $\begin{array}{l}\text { Things on the Internet disappeared with time, so it does not } \\
\text { matter what you post on the Internet }\end{array}$ & -2.33 & 4.91 \\
\hline $\begin{array}{l}\text { How to block messages on social media sites from people } \\
\text { you do not want to be in contact with }\end{array}$ & 2.72 & 6.65 \\
\hline $\begin{array}{l}\text { How to block messages on instant messaging program from } \\
\text { people you do not want to be in contact with }\end{array}$ & -2.04 & 3.27 \\
\hline I share my social media passwords with other people & -2.15 & 3.62 \\
\hline $\begin{array}{l}\text { How to protect a smartphone with a PIN or with a screen } \\
\text { pattern }\end{array}$ & -3.72 & 13.30 \\
\hline
\end{tabular}

\subsubsection{Main Study: Sample and Procedure}

From March to May 2016 the survey was conducted. Data were collected from 1,467 students of secondary education from $1^{\text {st }}$ to $4^{\text {th }}$ grade of secondary education at thirteen schools in both rural (seven schools) and urban (six schools) areas of Spain (51\% respondents from a rural school). Among these thirteen schools, four were public, eight (publicly funded) private and one private (see Appendix 1). Students were between 12 and 18 years old, and their mean age was $13.97(S D=1.31)$. Moreover, 52\% of participants were men and $48 \%$ were women. Of the 1,467 participants, 21 were excluded from the analysis because they did not properly fill out the questionnaires. 
Therefore, $1 \%$ of records were incomplete and considered invalid. In the end, 1,446 participants were retained for the analysis.

The thirteen participating schools (and the participating school in the pilot study) were self-selected, responding to an invitation to participate in the research project (see Appendix 2). The online invitation to participate in the experiment was sent to 327 schools. The contact rate was $7.64 \%$, since only 25 attempts to contact were successful, but then some schools refused to participate for different reasons (e.g., lack of time). Finally, the response rate was $3.66 \%$ as 13 of the contacted schools agreed to participate.

During the survey, participants were administered a paper-and-pencil questionnaire under the supervision of a researcher and teacher during class. The survey took about 15-30 min to complete and it contained measures of digital literacy, positive ICT attitude and technology anxiety (as convergent validation measures), as well as other variables not of interest for the current study.

A consent form was sent to parents/carers of students in the participating schools (see Appendix 3). Participants were told about the nature of the study and given contact detail of the study's representatives to consult if necessary. They were guaranteed confidentiality and anonymity. Informed consent was received from school staff (school principals and heads of studies) and the corresponding Provincial Education Directorate. Participants did not get any compensation for taking part in the study.

\subsubsection{Measures}

Digital Literacy: The digital literacy scale consisted of 35 items that were measured with a 5-point Likert scale of self-reported agreement, responses ranging from $1=$ strongly disagree to $5=$ strongly agree. These items were adapted and created for each of the previous five dimensions identified for digital literacy identified (five digital 
skills: technological skill, security skill, critical skill, informational skill and communication skill).

Convergent validity: To assess convergent validity we included two measures that were expected to relate to digital literacy: positive ICT attitude and technology anxiety.

Positive ICT attitude was assessed using eleven items adapted from the literature (Fraillon, Ainley, Schulz, Friedman, \& Gebhardt, 2014; Ng, 2012; Wilkinson, Roberts, \& While, 2010). Items were measured with a 5-point Likert scale of agreement, from $1=$ strongly disagree to $5=$ strongly agree (e.g., "It is more fun to do homework using a computer than without it"). All items loaded on the one factor, with factor loadings ranging from .40 to .77 and an explained variance of $39 \%(\alpha=.84$; $M=3.57, S D=.71$ ).

Technology anxiety was measured with nine items on a 5-point Likert scale of agreement, from $1=$ strongly disagree to $5=$ strongly agree, which have been used to assess technology anxiety in previous studies (Barbeite \& Weiss, 2004; Heinssen, Glass, \& Knight, 1987). The nine items (e.g., "Computers make me feel uneasy and confused") loaded on one factor with factor loadings ranging from .58 to .73 and an explained variance of $43 \%(\alpha=.83 ; M=1.89, S D=.68)$.

\subsubsection{Data Analysis}

Data were analysed using SPSS 22 and AMOS 20. First, and to examine crosspopulation validity, we randomly divided the data into two groups (Sumter et al., 2015) i.e., sample $1, n=715$ and sample $2, n=730$. The first sample was used for conducting exploratory factor analysis (EFA) to discover the latent digital skills. The internal consistency of these constructs was then checked with Cronbach's alpha. The convergent validity of the Digital Literacy Scale with the Positive Attitude towards Technology Scale and the Technology Anxiety scale was assessed using Pearson's 
RISKS OF INTERACTIVE COMMUNICATION IN ADOLESCENTS.

DIGITAL LITERACY DIAGNOSIS AND INTERVENTION

correlation coefficient. Subsequently, the second sample was used for conducting confirmatory factor analysis (CFA) on the Digital Literacy Scale with AMOS.

Given the fact that the Shapiro-Wilk test showed that the variables failed to meet the normality assumption, a bootstrap method was used in the analysis with AMOS. We estimated $95 \%$ bias-corrected confidence intervals with 1.000 bootstrapping samples. In this context, an association is considered statistically significant if the confidence intervals $(95 \% \mathrm{BCI})$ do not include zero. Taking into consideration that a bootstrap method cannot be performed with missing data, missing values were replaced using the linear trend at point technique in SPSS. None of the variables had more than $3 \%$ cases missing and most of them had missing data in less than $1 \%$ of the cases. Results were not affected neither by the replacement missing values nor by the bootstrap methods.

\subsection{Results}

\subsubsection{Exploratory Factor Analysis}

The skills items in the survey were examined using an exploratory factor analysis with the aim of specifying the underlying structure in the data matrix (Hernández-Ramos, Martínez-Abad, García-Peñalvo, Herrera García, \& Rodríguez-Conde, 2014). Prior to this step, we performed the Bartlett's test for sphericity to investigate the factorability of the data and the Kaiser-Meyer-Olkin (KMO) test to measure the sampling adequacy (Lau \& Yuen, 2014). The KMO measure of sampling adequacy yielded a value of .90 and the test of sphericity was significant $\left(\chi^{2}(595)=5,862.715, p<.001\right)$, meaning that the data were suitable for structure detection.

Because of these values, we performed an exploratory factor analysis using the principal component extraction method and varimax rotation on the 35 items with the aim of identifying the factors (see Table 17). One item with a low communality (<.30), a factor with only one item loading on it, and another factor with no theoretical 
association between its four items and a low eigenvalue, were removed. Finally, the EFA revealed the existence of six factors with eigenvalues over 1.o that accounted for $44.3 \%$ of the total variance: technological skill, personal security skill, critical skill, device security skill, informational skill and communication skill. Thus, the factor that was originally set as security skill is divided into two security categories: personal security skill and device security skill. The internal consistency reliability of the factors was also examined using Cronbach's alpha and it was found to be reliable in five of the six factors, with Cronbach's Alpha levels ranging from .63 to .75 . However, the communication skill factor showed an unacceptable Cronbach's alpha value $(\alpha=.46)$. As we are in the early stages of research, even when we acknowledge that the reliability of this factor is low, we decided to retain the factor with the aim of improving it in future research.

In any case, and in respect of the development of the digital literacy scale, the result shows that the assessment tool resembles the model originally proposed. It is composed of six components and 29 items: technological skill, personal security skill, critical skill, devices security skill, informational skill and communication skill. Table 18 reports the six factors solution with the corresponding eigenvalues, the explained variance and the Cronbach's value for each factor. It also reports the factor loadings for each item on each factor. 
RISKS OF INTERACTIVE COMMUNICATION IN ADOLESCENTS.

DIGITAL LITERACY DIAGNOSIS AND INTERVENTION

Table 17.

Exploratory Factor Analysis matrix loadings

\begin{tabular}{|c|c|c|c|c|c|c|c|}
\hline Initial item & New item & 1 & 2 & 3 & 4 & 5 & 6 \\
\hline Tec_3 & Tecı & $\cdot 731$ & .146 & .159 & .121 & .049 & -.027 \\
\hline Tec_1 & Tec2 & .684 & .107 & .292 & -.024 & .021 & .081 \\
\hline Inf_9 & Тесз & .498 & .202 & .067 & .298 & .139 & .056 \\
\hline Tec_2 & Tec4 & .498 & .082 & .079 & .142 & .068 & .305 \\
\hline Tec_4 & Tec5 & .454 & .116 & .068 & .424 & -.029 & -.102 \\
\hline Tec_7 & Теc6 & .445 & .168 & -.022 & .056 & .270 & .064 \\
\hline Tec_6 & Tec7 & .440 & .162 & -.047 & .383 & .251 & -.105 \\
\hline Seg_3 & Ps1 & .298 & .671 & .120 & .164 & .064 & .007 \\
\hline Seg_8 & Ps2 & .074 & .646 & .203 & .101 & .008 & .109 \\
\hline Seg_2 & Ps3 & .168 & .637 & .175 & .198 & .095 & .158 \\
\hline Seg_1 & Ps4 & .339 & .585 & .112 & .051 & .132 & .262 \\
\hline Seg_9 & Ps5 & -.101 & .425 & .407 & .167 & .083 & -.137 \\
\hline Cri_3 & Criı & .199 & .143 & .707 & .003 & .054 & .083 \\
\hline Cri_1 & Cri2 & .124 & .182 & .675 & .238 & .134 & -.013 \\
\hline Cri_2 & $\mathrm{Cri}_{3}$ & .061 & .056 & .646 & .309 & .111 & .051 \\
\hline Cri_4 & Cri4 & .138 & .231 & .589 & .093 & .088 & .150 \\
\hline Cri_5 & $\mathrm{Cri}_{5}$ & .088 & .365 & .381 & .169 & .010 & -.043 \\
\hline Seg_6 & Ds1 & .087 & .023 & .209 & .751 & .033 & .128 \\
\hline Seg_5 & Ds2 & .069 & .125 & .227 & .746 & .097 & .060 \\
\hline Seg_7 & Ds3 & .133 & .230 & .203 & .574 & .069 & .008 \\
\hline Tec_5 & Ds4 & .236 & .335 & .001 & .500 & .161 & .033 \\
\hline Inf_1 & Inı & -.017 & .007 & .029 & .068 & .697 & .215 \\
\hline Inf_4 & In 2 & .137 & .026 & -.005 & .123 & .641 & .115 \\
\hline Inf_5 & $\mathrm{In}_{3}$ & .103 & .145 & .193 & .118 & .596 & -.149 \\
\hline Inf_2 & $\operatorname{In}_{4}$ & .105 & -.015 & .073 & -.004 & .570 & .000 \\
\hline Inf_3 & In 5 & .104 & .136 & .212 & -.012 & .500 & -.228 \\
\hline Com_3 & Co1 & .032 & .208 & .111 & .057 & .046 & .723 \\
\hline Com_2 & $\mathrm{Co} 2$ & .348 & .372 & .068 & .105 & .135 & .463 \\
\hline Com_1 & $\mathrm{Co} 3$ & .231 & -.165 & .110 & .042 & .045 & .308 \\
\hline
\end{tabular}


Table 18.

Exploratory factor analysis for the Digital Literacy Scale

\begin{tabular}{|c|c|c|c|c|}
\hline Factors (items of the scale: know how to...) & $\begin{array}{l}\text { Factor } \\
\text { loadings }\end{array}$ & Eigenvalue & $\begin{array}{l}\text { Explained } \\
\text { variance }\end{array}$ & $\alpha$ \\
\hline Technological skill & & $7 \cdot 406$ & $21.16 \%$ & .73 \\
\hline Tecı. Bookmark a website I like so I can view it later & .731 & & & \\
\hline Tec2. Download/save a photo I found online & .684 & & & \\
\hline Tec3. Download information I found online & .498 & & & \\
\hline Tec4. Connect always to a Wi-Fi network from smartphone, no matter the device or where I am & .498 & & & \\
\hline Tec5. Use shortcut keys (e.g., CTRL+C o cmd+C for copy) & .454 & & & \\
\hline $\begin{array}{l}\text { Tec6. I don't like downloading apps for smartphones as I find difficult to learn how to use them } \\
\text { (recoded) }\end{array}$ & .445 & & & \\
\hline $\begin{array}{l}\text { Tec7. If I want to install new programs on my computer, I will ask someone to do it for me } \\
\text { because I don't know (recoded) }\end{array}$ & .440 & & & \\
\hline Personal security skill & & 2.311 & $6.60 \%$ & .73 \\
\hline Psi. Deactivate the function showing my geographical position (e.g., Facebook, apps) & .671 & & & \\
\hline Ps2. I know when I can post pictures and videos of other people online & .646 & & & \\
\hline $\begin{array}{l}\text { Ps3. Use 'report abuse' buttons on social media sites (e.g., Someone uses my photo without my } \\
\text { permission) }\end{array}$ & .637 & & & \\
\hline $\begin{array}{l}\text { Ps4. Change the sharing settings of social media to choose what others can see about me } \\
\text { (friends of friends, friends only, only me) }\end{array}$ & .585 & & & \\
\hline Ps5. I know the consequences of illegal downloading of music and movies & .425 & & & \\
\hline
\end{tabular}




\begin{tabular}{|c|c|c|c|c|}
\hline Factors (items of the scale: know how to...) & $\begin{array}{l}\text { Factor } \\
\text { loadings }\end{array}$ & Eigenvalue & $\begin{array}{l}\text { Explained } \\
\text { variance }\end{array}$ & $\alpha$ \\
\hline Critical skill & & 1.898 & $5.42 \%$ & $\cdot 75$ \\
\hline Cri. Compare different sources to decide if information is true & $\cdot 707$ & & & \\
\hline $\mathrm{Cr} 2$. Determine if the information I find online is reliable & .675 & & & \\
\hline $\mathrm{Cr}_{3}$. Identify the author of the information and evaluate their reliability & .646 & & & \\
\hline $\mathrm{Cr}_{4}$. Compare different apps in order to choose which one is most reliable and secure & .589 & & & \\
\hline Cr5. If I meet someone online, I know how to check if their profile is real & .381 & & & \\
\hline Device security skill & & 1.454 & $4.15 \%$ & .72 \\
\hline Dsı. Use software to detect and remove viruses & .751 & & & \\
\hline Ds2. Detect a virus in my digital device & .746 & & & \\
\hline Ds3. Block unwanted or junk mail/spam & .574 & & & \\
\hline $\begin{array}{l}\text { Ds4. If something doesn't work occurs while I am using a device (computer, smartphone, etc.), I } \\
\text { usually know what it is and how to fix the problem }\end{array}$ & .500 & & & \\
\hline Informational skill & & 1.386 & $3.96 \%$ & .63 \\
\hline Inı. I find hard to decide what the best keywords are for online searching (recoded) & .697 & & & \\
\hline In2. I find confusing the way in which many websites are designed (recoded) & .641 & & & \\
\hline $\begin{array}{l}\text { In3. Sometimes I find difficult to determine how useful the information is for my purpose } \\
\text { (recoded) }\end{array}$ & .596 & & & \\
\hline In4. I get tired when looking for information online (recoded) & .570 & & & \\
\hline In5. Sometimes I end up on websites without knowing how I got there (recoded) & .500 & & & \\
\hline
\end{tabular}




\begin{tabular}{lrrr}
\hline Factors (items of the scale: know how to...) & $\begin{array}{l}\text { Factor } \\
\text { loadings }\end{array}$ & Eigenvalue & $\begin{array}{l}\text { Explained } \\
\text { variance }\end{array}$ \\
\hline Communication skill & 1.060 & $3.02 \%$ & .46 \\
\hline
\end{tabular}

Col. Depending on who I want to communicate with, it is better to use one method over the other (make a call, send a WhatsApp message, send an email, etc.)

Co2. Send any file to a contact using a smartphone

.723

Co3. No matter with who I communicate: emojis are always useful (recoded) 


\subsubsection{Confirmatory Factor Analysis}

With the aim of confirming the structural validity of the Digital Literacy Scale and establishing cross-population validity, a confirmatory factor analysis was performed in AMOS 20 using the second half of the data $(\mathrm{N}=731)$. The overall structure of the scale was tested using CFA with maximum likelihood estimation and the bootstrap method. In this process, one item (i.e., "I know the laws and consequences of illegal downloading of music and movies") was deleted due to its low factor loading (o.26) in the Personal Security Skill latent factor. Figure 1o depicts the dimensional structure of our factor model. In this figure, ovals represent latent constructs (digital skills), whereas rectangles represent observed items. The model fit was just short of the recommended criteria: $X^{2}(335)=848.73, p<.001, \mathrm{CFI}=.89$, RMSEA $=.046(95 \%[\mathrm{CI}]$ $=[.04, .05])^{4}$.

In view of the significant correlation coefficients between all dimensions of skills (ranging from .134 to .789) a second-order CFA was conducted for confirming that they were related to a higher-order dimension (Lemmens, Valkenburg, \& Peter, 2009). Therefore, the six latent factors were loaded into a second-order latent factor (digital literacy). Results suggested that the model fit was again slightly less than the recommended criteria: $X^{2}(344)=969.085, p<.001, \mathrm{CFI}=.87, \mathrm{RMSEA}=.05(95 \%[\mathrm{CI}]$ $=[.04, .05])^{5}$. Table 19 shows the standardised regression weights between the second order factor (digital literacy) and the six first-order factors (six digital skills), all of them statistically significant at the alpha level of .oor.

\footnotetext{
${ }^{4}$ Considering the presence of large modification indices, a model with error term correlations considering large modification indices was tested. Nevertheless, there were no substantial differences between the two models. The inclusion of correlations only implied a slight improvement of the fit: $X^{2}(332)=769.357, p<$ $.001, \mathrm{CFI}=.91, \mathrm{RMSEA}=.04(95 \%[\mathrm{CI}]=[.04, .05])$. For this reason, and taking into account that some scholars reject this procedure (Hermida, 2015), we decided to retain the original model without error term correlations.

5 The inclusion of error terms correlations in the second-order CFA implied also a slight improvement of the fit: $X^{2}(341)=892.603, p<.001, \mathrm{CFI}=.88, \mathrm{RMSEA}=.05(95 \%[\mathrm{CI}]=[.04, .05])$. Following the same criteria as described above, the original model without error term correlations was retained.
} 
Table 19.

Standardised regression weights

\begin{tabular}{lc}
\hline & Digital Literacy \\
\hline Technological Skill & .876 \\
Personal Security Skill & .826 \\
Critical Skill & .660 \\
Device Security Skill & .694 \\
Informational Skill & .401 \\
Communication Skill & .778 \\
\hline
\end{tabular}

\subsubsection{Convergent Validity of the Digital Literacy Scale}

To examine the convergent validity, we correlated the different dimensions of the Digital Literacy Scale with the attitude to technology and technology anxiety (see Table 20). Moreover, digital literacy was also correlated with the age and the gender ${ }^{6}$ of the participants. As we expected from previous literature, a positive attitude to technology has significant positive correlations with the different digital skills and with the level of digital literacy. On the other hand, technology anxiety has negative correlations with digital skills and with digital literacy. Similarly, the age of the participant was positively related to the level of digital literacy $(r=.10, p<.01)$, with older students reporting higher levels of this literacy. Likewise, and also as expected from literature, male adolescents reported higher levels of digital literacy than female adolescents $(r=-.15, p<.001)$. Considering these results, it could be argued that the scale is valid in terms of construct validity (Noar, 2003).

\footnotetext{
${ }^{6}$ To conduct a correlation between gender and digital literacy, gender was transformed into a dummy variable $(\mathrm{o}=$ male, $1=$ female $)$.
} 


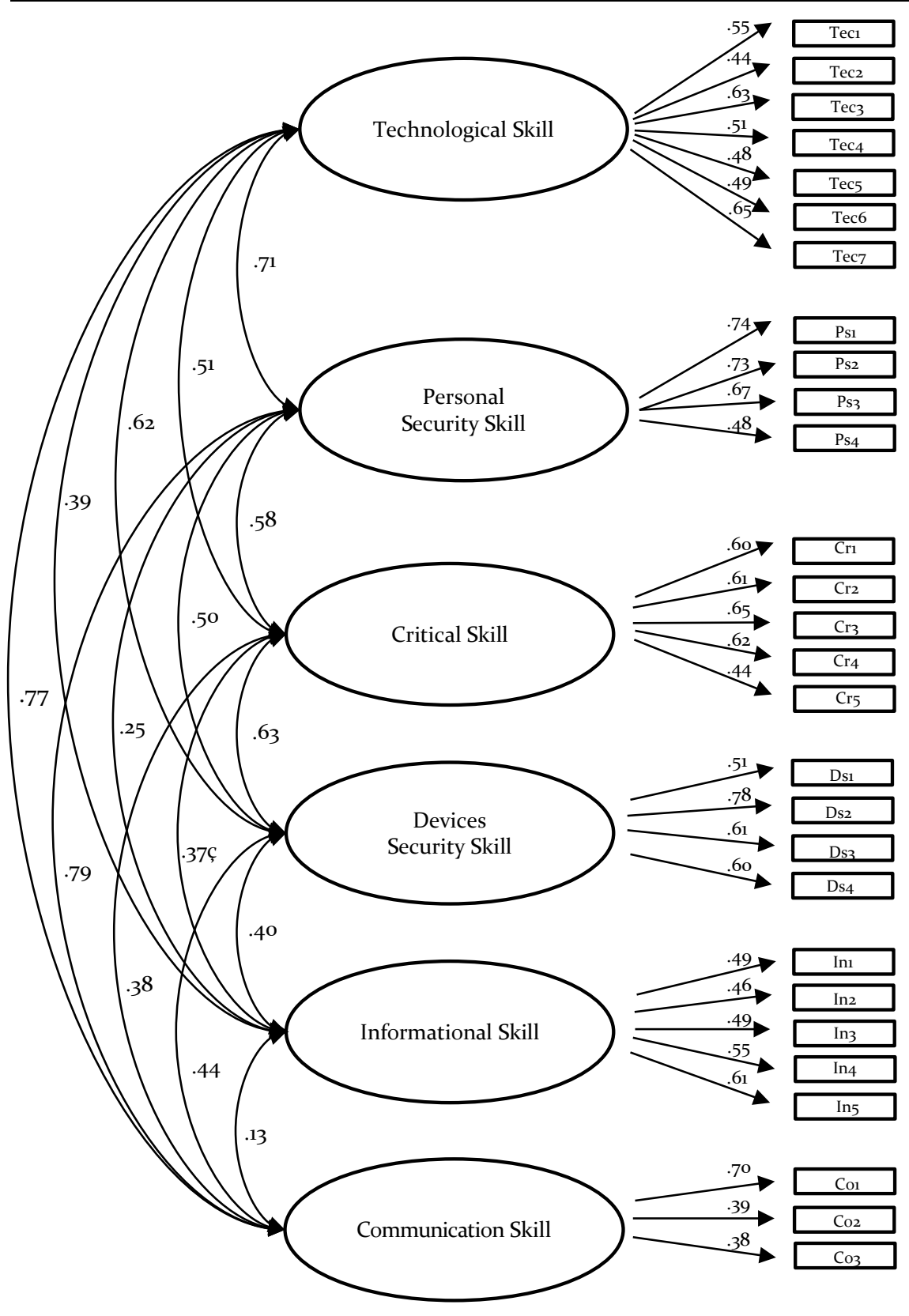

Figure 10. Confirmatory factor analysis solution for the Digital Literacy Scale 


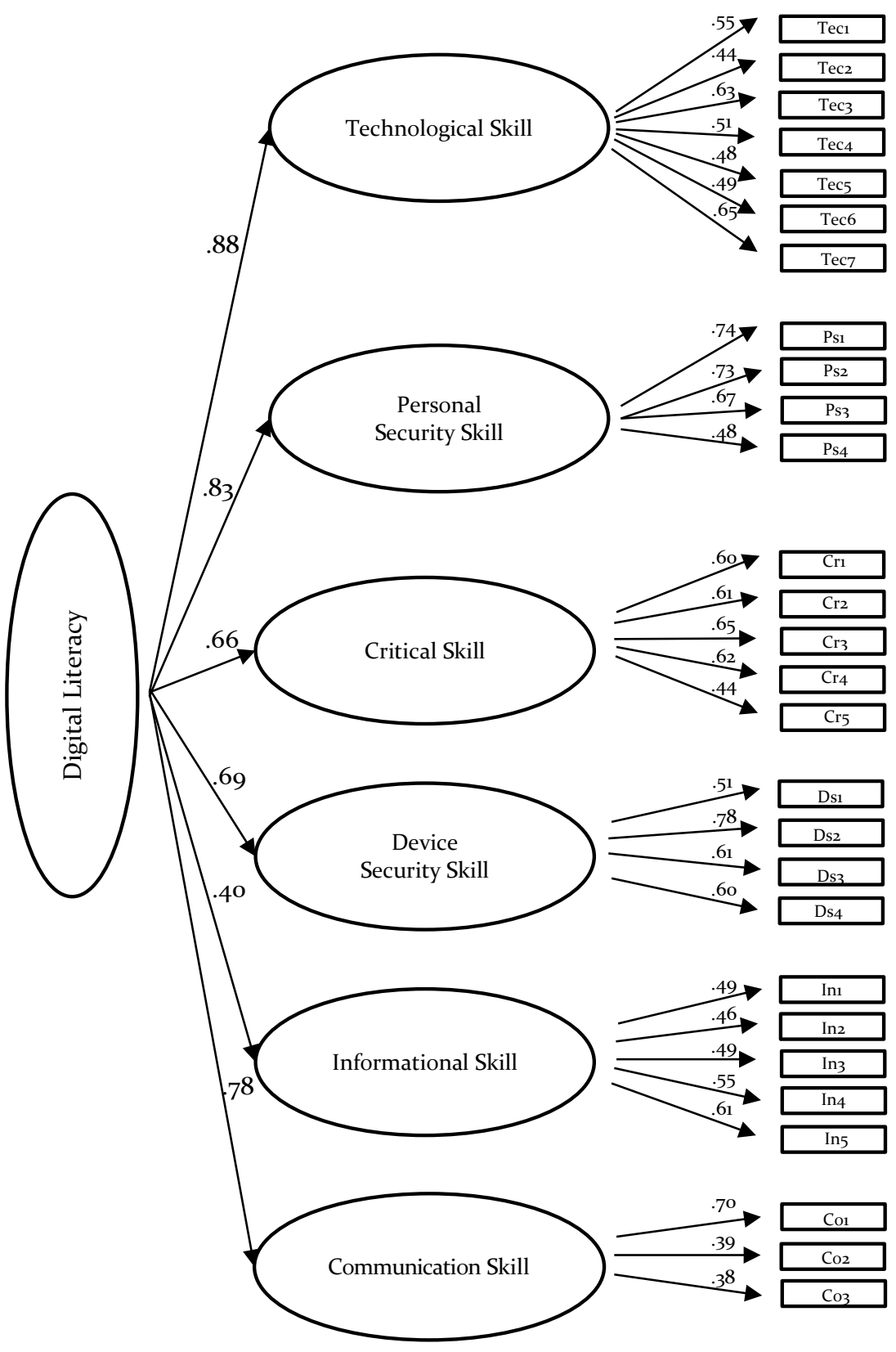

Figure 11. Second-order factor structure of the Digital Literacy Scale 
RISKS OF INTERACTIVE COMMUNICATION IN ADOLESCENTS.

DIGITAL LITERACY DIAGNOSIS AND INTERVENTION

Table 20.

Convergent validity: correlations

\begin{tabular}{llcc}
\hline & & Positive ICT attitude & Technology anxiety \\
\hline & Technological & $.51^{* * *}$ & $-.51^{* * *}$ \\
& Personal Security & $.34^{* * *}$ & $-.29^{* * *}$ \\
\multirow{2}{*}{ Digital Skills } & Critical & $.31^{* * *}$ & $-.26^{* * *}$ \\
& Device Security & $.39^{* * *}$ & $-.33^{* * *}$ \\
& Informational & $.14^{* * *}$ & $-.35^{* * *}$ \\
& Communication & $.14^{* * *}$ & $-.18^{* * *}$ \\
\hline Digital literacy & & $.47^{* * *}$ & $-.49^{* * *}$ \\
\hline & & & $* .001$
\end{tabular}

\subsection{Discussion}

The purpose of the present study was to create a methodological tool to assess the level of digital literacy of adolescents. Consequently, we developed and validated a scale through different steps. First, and based on previous literature, we developed a self-report scale of 47 items. Secondly, we conducted a pilot study with the aim of improving the scale. Then, an exploratory factor analysis showed the existence of six different digital skills (technological skill, personal security skill, critical skill, device security skill, informational skill and communication skill). A confirmatory factor analysis confirmed the structural validity of Digital Literacy Scale. Moreover, some correlations confirmed the convergent validity of the scale. Despite some room for improvement in the measurement, we argue that even in its current state this is a valid and reliable instrument for measuring digital skills on teenagers and as such fills a gap in the field of digital literacy research. 
In any case, and in respect of the development of the digital literacy scale, the result shows that the assessment tool resembles the model originally proposed. It is composed of six factors (digital skills) and 28 items (see Table 21).

Table 21.

Digital skills on the Digital Literacy Scale

\begin{tabular}{ll}
\hline Digital skill & Characteristics \\
\hline Technological skill & Ability to effectively use digital technologies \\
Communication Skill & $\begin{array}{l}\text { Ability to communicate through digital technologies } \\
\text { Ability to find information, obtain it, and evaluate its } \\
\text { relevance in the digital environment }\end{array}$ \\
Information skill & $\begin{array}{l}\text { Ability to critically analyse the information obtained online } \\
\text { Critical skill }\end{array}$ \\
Personal security skill to use interactive communication without taking \\
risks and dangers that could affect the personal safety of \\
minors \\
Device security skill
\end{tabular}

However, this study has also some limitations. First, the model fit of the two confirmatory factor analyses of the Digital Literacy Scale were just short of the recommended criteria. This means that the current data does not reflect the constructs very well. This may be due to suboptimal measurements of the constructs in our study. In this regard, the communication skill factor in the Digital Literacy Scale shows low internal consistency (Cronbach's alpha $=.46$ ). Moreover, the informational skill factor has also a questionable reliability (Cronbach's alpha $=.63$ ).

As we were in the early stages of the research, intending to establish the validity and the structure of the Digital Literacy Scale, we decided to retain both factors, although admitting that their reliability is low. In the case of the communication skill, this factor is only measured through three items and it seems that new items could be added with the aim of improving internal consistency. 
RISKS OF INTERACTIVE COMMUNICATION IN ADOLESCENTS.

DIGITAL LITERACY DIAGNOSIS AND INTERVENTION

Moreover, wording of the actual items should be checked again in order to look for

enhancements. Therefore, future research may look into improvements of the measurements of the Digital Literacy Scale, and in particular for the factors communication skill and informational skill. 


\title{
Chapter 7.
}

\section{STUDY 2.}

\section{RELATIONSHIP BETWEEN}

\section{PARENTAL MEDIATION AND}

\author{
ADOLESCENTS' DigitAL \\ SKILLS, ONLINE RISKS AND \\ ONLINE OPPORTUNITIES7
}

7 Part of this chapter is published as:

Rodríguez-de-Dios, I., van Oosten, J. M. F., \& Igartua, J.-J. (2018). A study of the relationship between

parental mediation and adolescents' digital skills, online risks and online opportunities. Computers in Human Behavior, 82, 186-198. 


\subsection{Introduction}

$\mathrm{W}$

ith the advance of digital technologies, concerns about adolescents' exposure to online risks and the importance of digital skills have been raised. First, when adolescents access the digital world, they might be exposed to potential online risks, such as cyberbullying, exposure to pornography and/or violence, sexting and contact with strangers, that have attracted the attention of researchers, educators and parents (Livingstone, Haddon, Görzig, et al., 2ona; Ólafsson et al., 2013; Rodríguez-de-Dios \& Igartua, 2016).

At the same time, it has been argued that discussions about adolescents and digital technologies should not only focus on online risks, but also need to take online opportunities into account (Livingstone, Mascheroni, et al., 2017). Digital technologies offer a broad range of opportunities for entertainment, communication, information and education that teenagers can take advantage of (Chisholm, 2006; Ktoridou et al., 2012; Livingstone \& Helsper, 2010; Vandoninck et al., 2010). As said in the theoretical background, some researchers argue that the best way to increase online opportunities and avoid online risks is to increase adolescents' digital skills. Moreover, in this relationship it is essential to consider also the influence that the two types of parental mediation (active and restrictive) could have on the level of teenagers' digital skills, and subsequently their online opportunities and online risks.

Consequently, the present study has two goals. First, we aim to examine if adolescents' digital skills are related to more online opportunities and less online risks. Second, we aim to study whether adolescents' digital skills mediate the relationship between parental mediation and adolescents' online risks and opportunities.

As was mentioned before, it is assumed that adolescents can avoid negative consequences of digital technologies by acquiring digital skills (Rodríguez-de-Dios \& Igartua, 2016; Sonck \& de Haan, 2014; Sonck et al., 2011). Thus, some scholars suggest 
that digital skills could be a prevention tool against online risks, taking into consideration the good results obtained by media literacy in addressing the harmful effects of mass media (Duran et al., 2008; Halliwell et al., 2011; Irving et al., 1998; Jeong et al., 2012). However, there are very few empirical studies that examine the relationship between digital skills and online risks (Sonck \& de Haan, 2014) and, contrary to what is expected, initial evidence suggests that the more skilled adolescents are, the more online risks they experience (S.-J. Lee \& Chae, 2012; Leung \& Lee, 2012b; Livingstone, Ólafsson, et al., 2017; Livingstone \& Helsper, 2010; Sonck \& de Haan, 2013; Staksrud et al., 2013).

Furthermore, and in regard to online opportunities, it is suggested that more digitally skilled teenagers will take better advantage of the multiple options offered by online media. However, research has usually focused on the relationship between digital skills and online risks, with fewer studies analysing the role of these skills in promoting online opportunities. In any case, research suggests that those who have more Internet skills or digital skills benefit more from online opportunities (S.-J. Lee \& Chae, 2012; Livingstone \& Helsper, 2010; Nikken \& Schols, 2015; Sonck \& de Haan, 2013). It is therefore important to study the impact that digital skills can have on both online risks and opportunities ${ }^{8}$ since finding the right balance between accessing online opportunities and experiencing online risks remains a challenge (Vandoninck et al., 2010).

Specifically, our first hypothesis states that digital literacy will predict online risk behaviours and online opportunities $\left(\mathrm{H}_{1}\right)$. From this main hypothesis, we set up the following subhypotheses:

Hia Digital literacy will predict online risk behaviours.

\footnotetext{
${ }^{8}$ Consistent with previous research in this field (Helsper \& Eynon, 2013; S.-J. Lee, 2012; S.-J. Lee \& Chae, 2012; Livingstone, Ólafsson, et al., 2017; Livingstone \& Helsper, 2010; Sasson \& Mesch, 2014; Sonck \& de Haan, 2013, 2014), we decided to conceptualize the different dimensions of online risks or online opportunities as one concept (online risks / online opportunities).
}

$$
\sim 167 \sim
$$


Hıb Digital literacy will predict online opportunities.

On another note, parental mediation has been generally considered as a useful strategy for risk prevention (Álvarez et al., 2013). According to previous research, active mediation works better than restrictive mediation in reducing online risks (Duerager \& Livingstone, 2012; Khurana et al., 2015; Lwin et al., 2008; W. Shin \& Kang, 2016) and restrictive mediation is both positively and negatively associated with these risks (Khurana et al., 2015; Lau \& Yuen, 2013; S.-J. Lee, 2012; S.-J. Lee \& Chae, 2012; Liau et al., 2005; Livingstone, Ólafsson, et al., 2017; Mitchell et al., 2003; Sasson \& Mesch, 2014; W. Shin \& Ismail, 2014; W. Shin \& Kang, 2016). Furthermore, active mediation is positively associated with minors' online opportunities (Ihmeideh \& Shawareb, 2014; Livingstone, Ólafsson, et al., 2017), while restrictive mediation is associated with fewer opportunities (Daud et al., 2014; Livingstone, Ólafsson, et al., 2017).

In addition to online risks and opportunities, researchers have recently also started to be concerned with the impact that parental mediation could have on adolescents' digital skills (Valcke et al., 2010; Zhang \& Zhu, 2016). Even so, empirical studies in this field are still very scarce. There are only two studies that have focused on parental mediation and digital skills among adolescents. Both of them conclude that active mediation is related to an increase in digital skills, whereas restrictive mediation reduces these skills (Cabello-Hutt et al., 2017; Duerager \& Livingstone, 2012). Consequently, more research is needed to clarify the impact of both types of parental mediation on adolescents' digital literacy.

In this sense, we hypothesise that parental mediation will predict adolescents' digital skills $\left(\mathrm{H}_{2}\right)$. From this main hypothesis, we set up the following subhypotheses:

Hza Active parental mediation will be positive predictor of adolescents' digital literacy. 
$\mathrm{H} 2 \mathrm{~b}$ Restrictive parental mediation will be negatively related to digital literacy.

Furthermore, previous research has investigated direct relationships between parental mediation, and either digital skills, online risks or online opportunities. That research showed that a) parental mediation may influence adolescents' digital skills, and that b) adolescents' digital skills influence online risks and opportunities. Hence, it can be expected that digital skills mediate the relationships between parental mediation and online risks and online opportunities. Nonetheless, no study to date has investigated such an indirect relationship within the same study.

Finally, we expect that digital literacy will mediate the relation between parental mediation and online risks and online opportunities $\left(\mathrm{H}_{3}\right)$. Therefore, we set the following subhypotheses:

Hza Active parental mediation will increase both online risks and online opportunities by increasing digital skills

$\mathrm{H}_{3} \mathrm{~b}$ Restrictive mediation will decrease online risks and online opportunities by decreasing digital skills.

Therefore, in the present study we will look not only at the influence of digital literacy on online risks and online opportunities, but also at how this construct mediates the relationship between parental mediation and risks and opportunities. Against this backdrop, we will test a model that shows the relationship between parental mediation, adolescents' digital literacy, online risks and online opportunities (see Figure 12). 


\subsection{Method}

\subsubsection{Sample and Procedure}

As in the previous study, from March to May 2016 a survey was conducted (see Appendix 4). Data were collected from 1,467 students of secondary education from $1^{\text {st }}$ to $4^{\text {th }}$ grade at thirteen schools in both rural (seven schools) and urban (six schools) areas of Spain (51\% respondents from a rural school). Among these thirteen schools, four were public, eight (publicly funded) private and one private (see Appendix 1). Students were between 12 and 18 years old, and their mean age was $13.97(S D=1.31)$. Moreover, $52 \%$ of participants were men and $48 \%$ were women. Of the 1,467 participants, 21 were excluded from the analysis because they did not properly fill out the questionnaires. Therefore, $1 \%$ of records were incomplete and considered invalid. In the end, 1,446 participants were retained for the analysis.

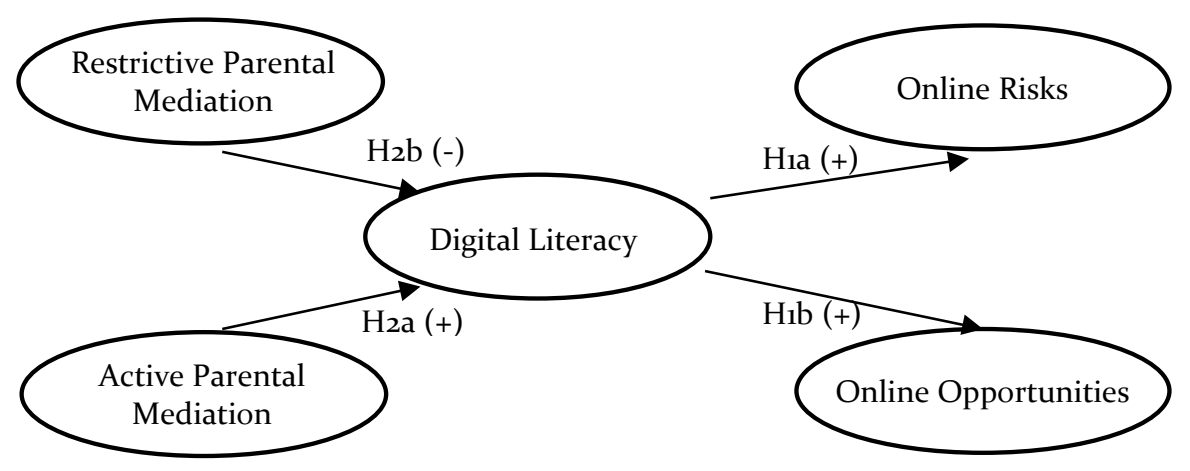

Figure 12. Relationship between parental mediation, digital literacy and online risks and online opportunities 
CHAPTER 7. STUDY 2. RELATIONSHIP BETWEEN PARENTAL MEDIATION AND ADOLESCENTS' DIGITAL SKILLS, ONLINE RISKS AND ONLINE OPPORTUNITIES

The thirteen participating schools (and the participating school in the pilot study) were self-selected, responding to an invitation to participate in the research project (see Appendix 2). The online invitation to participate in the experiment was sent to 327 schools. The contact rate was $7.64 \%$, since only 25 attempts to contact were successful, but then some schools refused to participate for different reasons (e.g., lack of time). Finally, the response rate was $3.66 \%$ as 13 of the contacted schools agreed to participate.

During the survey, participants were administered a paper-and-pencil questionnaire under the supervision of a researcher and teacher during class. The survey took about 15-30 minutes to complete and it contained measures of parental mediation, digital literacy, online risk behaviours and online opportunities, as well as other variables not of interest for the current study.

A consent form was sent to parents/carers of students in the participating schools (see Appendix 3). Participants were told about the nature of the study and given contact detail of the study's representatives to consult if necessary. They were guaranteed confidentiality and anonymity. Informed consent was received from school staff (school principals and heads of studies) and the corresponding Provincial Education Directorate. Participants did not get any compensation for taking part in the study.

\subsubsection{Measures}

Parental mediation: This was assessed using twelve items adapted from previous studies (Khurana et al., 2015; J. I. Martínez, Cortés, Medrano, \& Apodaca, 2014; Sasson \& Mesch, 2014). Five of these twelve items were designed to measure restrictive parental mediation, whereas seven items were developed for assessing active or instructive parental mediation. Many scholars have shown disagreement between parents and children in reporting parental mediation (Baxter, Bylund, Imes, \& 
Routsong, 2009; Buijzen, Rozendaal, Moorman, \& Tanis, 20o8; Vaterlaus, Beckert, Tulane, \& Bird, 2014). Therefore, some of them suggest investigating both parents and children. However, this "can be time- consuming and expensive, and the question remains how to treat such complex family data" (Buijzen et al., 2008, p. 523). For that reason, some scholars recommend using child reports of parental mediation as they are more reliable predictors of the mediation outcome (Fujioka \& Austin, 2003; Nathanson, 2001).

On a scale ranging from $1=$ never to $5=$ always, adolescents reported on how often their parents engage in certain regulatory behaviours of their media use (e.g., "restrict the amount of time you spend online" [restrictive mediation] or "explain why some websites are good or bad" [active or instructive mediation]). Exploratory factor analyses (EFA) revealed that these items, with factor loadings above .50 , loaded on the two latent factors previously proposed, which accounted for $58 \%$ of the explained variance $(E V)$ : restrictive parental mediation $(E V=22 \% ; \alpha=.76 ; M=1.95, S D=.80)$ and active parental mediation $(E V=36 \% ; \alpha=.89 ; M=2.85, S D=1.10)$. The means are based on the variables that were created by making a mean score of the separate items for each type of parental mediation.

Digital Literacy: Six different digital skills were assessed with 28 items that were measured with a 5-point Likert scale of self-reported agreement, responses ranging from $1=$ strongly disagree to $5=$ strongly agree. As also reported previously, EFA revealed that these items loaded on six latent factors that together accounted for $44 \%$ of the variance: technological skill $(E V=21.16 \% ; \alpha=.73 ; M=3.80, S D=.73)$, personal security skill $(E V=6.60 \% ; \alpha=.75 ; M=4.08, \mathrm{SD}=.83)$, critical skill $(E V=$ $5.42 \% ; \alpha=.73 ; M=3.43, S D=.74)$, device security skill $(E V=4.15 \% ; \alpha=.71 ; M=3.25$, $S D=.93)$, informational skill $(E V=3.96 \% ; \alpha=.63 ; M=3.37, S D=.70)$ and communication skill $(E V=3.02 \% ; \alpha=.46 ; M=3.69, S D=.58)$. Mean scores are based on the variables that were created by taking the means of the separate items. After a 
CFA, which confirmed that the six factors were related to a higher-order dimension, a latent variable (digital literacy) was created and included in the model.

Online Risk Behaviours: Eighteen items were developed, based on previous studies (Álvarez-García, Dobarro, \& Núñez, 2015; Livingstone \& Helsper, 2010; Valcke et al., 2011), for measuring online risk behaviours. On a scale ranging from $1=$ never to $5=$ always, adolescents reported on how often they engage in certain activities online (e.g., "Send personal pictures to people I meet online" or "Visit a porn site on purpose"). EFA revealed that these items loaded on five latent factors that accounted for $61 \%$ of the total explained variance: contact with strangers $(E V=15 \% ; \alpha=.76 ; M$ $=1.61, S D=.64)$, exposure to pornography $(E V=13 \% ; \alpha=.80 ; M=1.40, S D=.69)$, exposure to violence $(E V=11 \% ; \alpha=.67 ; M=1.25, S D=.55)$, cyberbullying victim $(E V=10 \% ; \alpha=.66$; $M=1.16, S D=.39)$ and cyberbullying perpetrator $(E V=11 \%$; $\alpha=.69 ; M=1.08, S D=.34)$. Two items (i.e., "someone has pretended to be me on the Internet and publish things to do me harm"; "I send photos of myself naked or of my private parts") were deleted from the analysis because they have high loadings on more than one factor and thus were not clearly indicative of one of the five latent factors. Means are based on the variables that were created by making a mean score of the separate items. After a CFA, which confirmed that the five factors were related to a higher-order dimension, a latent variable (online risks) was created and included in the model.

Online Opportunities: Following Vandoninck et al. (2010), we conceptualize online opportunities as the use of online applications, such as applications directed at communicating. In this sense, it is important to point out that the main difference between online risks and online opportunities is that online opportunities generally afford positive benefits for children, whereas online risks are associated with a certain likelihood of harm (Livingstone, 2013). In any case, online opportunities do not always imply benefit and, likewise, online risks do not always imply harm. 
RISKS OF INTERACTIVE COMMUNICATION IN ADOLESCENTS.

DIGITAL LITERACY DIAGNOSIS AND INTERVENTION

Eleven items on a 5-point Likert scale, being $1=$ never, $\mathbf{2}=$ less frequently than the above, $3=2-3$ times per week, $4=$ once a day, $5=$ several times a day, were developed for measuring different online activities ( e.g., "use photo or video editing software", "use instant messaging"; Vandoninck et al., 2010). EFA revealed the existence of three latent factors: Communication, that is, the use of applications directed at communicating, such as instant messaging or social networking sites, ( $E V$ $=20 \% ; \alpha=.53 ; M=3.97, S D=.67$ ); Entertainment, use of applications directed at searching for entertainment, such as playing games or downloading games, $(E V=17 \%$; $\alpha=.74 ; M=2.84, S D=1.09$ ); and Multimedia, use of applications related to multimedia, such as downloading films/music or using photo or video editing software $(E V=16 \% ; \alpha=.58 ; M=2.42, S D=.93)$. One item (i.e., "download apps") was deleted because it loaded on two factors. All the factors, which accounted for $53 \%$ of the total explained variance, were submitted to a CFA. As it showed that they were related to a higher-order dimension, only one latent factor (online opportunities) was included in the model.

\subsubsection{Data analysis}

Data were analysed using SPSS 22 and AMOS 20. Considering previous multiple regression analyses performed in SPSS, AMOS was used to test the hypotheses in a structural equation model using the entire sample. In this model, we used latent factors as indicators of the three second-order factors (digital literacy, composed of six digital skills; online risks, composed of five online risks; and online opportunities, composed of three types of online opportunities) and two latent constructs (restrictive mediation and active mediation). Moreover, only two latent constructs (restrictive and active parental mediation) were allowed to covary.

Given the fact that Shapiro-Wilk test showed that the variables failed to meet the normality assumption, a bootstrap method was used in the analysis with AMOS. 
We estimated $95 \%$ bias-corrected confidence intervals with 1.000 bootstrapping samples. In this context, an association is considered statistically significant if the confidence intervals $(95 \% \mathrm{BCI})$ do not include zero. Taking into consideration that a bootstrap method cannot be performed with missing data, missing values were replaced using the linear trend at point technique in SPSS. None of the variables had more than $3 \%$ cases missing and most of them had missing data in less than $1 \%$ of the cases. Results were not affected neither by the replacement missing values nor by the bootstrap methods.

\section{7·3. Results}

\subsubsection{Testing the Hypothesised Model}

To test our hypotheses, a structural equation model was constructed using AMOS (see Figure 13). Both types of parental mediation (restrictive and active) were included as predictor variables of digital literacy. Concurrently, digital literacy was added as a predictor of online risks and online opportunities. Following the principle of parsimony, we developed the model with second-order factors (digital literacy, online risks and online opportunities; Brown, 2015; Chen, Sousa, \& West, 2005; Field, 2013; Hayes, 2005; Kline, 2013) 9.

We used two indices to evaluate the fit of our models: the root mean square of approximation (RMSEA) and the comparative fit index (CFI). Results demonstrate a modest level of fit: $X^{2}(290)=1251,782, p<.001$, comparative fit index $(\mathrm{CFI})=.84$, root mean square error of approximation $($ RMSEA $)=.07(95 \%$ confidence interval $[\mathrm{CI}]=$ $[.06, .07])^{10}$.

9. We must highlight that a model without second-order factors and with manifest items loading on the latent factors was built for testing purposes. It produced a worse level of fit, $\mathrm{X}_{2}(2018)=8528,7$, p < .001, CFI $=.77, \mathrm{RMSEA}=.05(95 \%[\mathrm{CI}]=[.04, .05])$, and it did not affect the core relationships being examined.

${ }^{10}$ Considering the presence of large modification indices, a model with error term correlations was tested. Nevertheless, there were no substantial differences between the two models. There was only a slight 


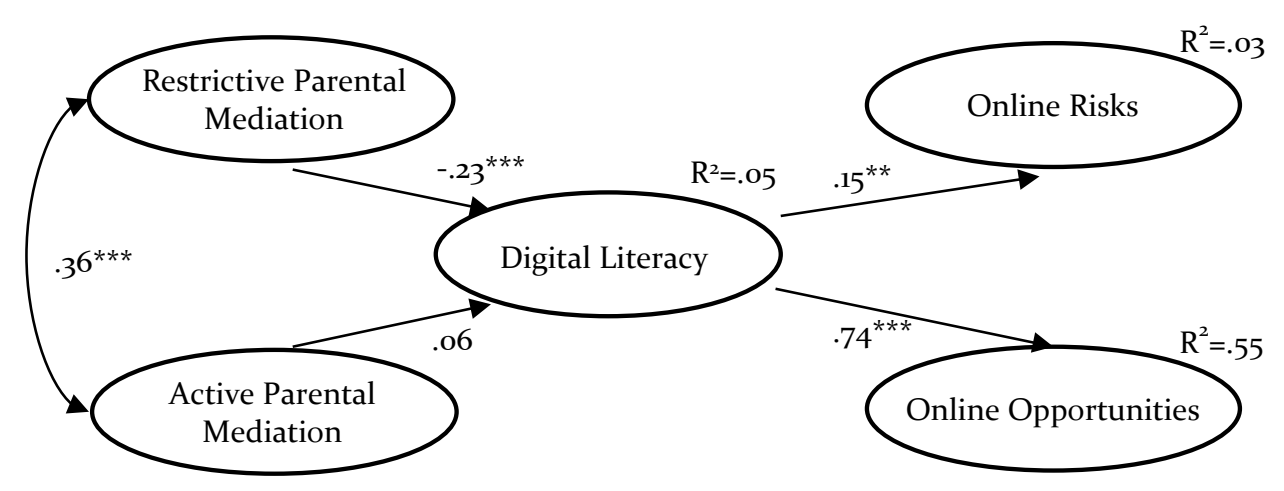

Figure 13. Structural Equation Model with standardised estimates

\section{Hypothesis 1: Digital literacy as a predictor of online risks and opportunities}

Hypothesis 1 predicted that digital literacy would be positive predictor of online risks (Hia) and online opportunities (Hib). The analysis suggested that digital literacy is positively related to online opportunities, $\beta=.74, b=.44$, $S E=.05, p<.001(95 \% \mathrm{BCI}$ $=[.558, .916])$, and online risks, $\beta=.15, b=.08, S E=.03, p=.004(95 \% \mathrm{BCI}=[.004$, $.269])$. Therefore, hypothesis $1 \mathrm{a}$ and $\mathrm{lb}$ are supported.

\section{Hypothesis 2: Parental mediation as a predictor of adolescents' digital literacy}

Hypothesis 2a stated that active parental mediation would be positive predictor of teenagers' digital literacy. In contrast, hypothesis $2 \mathrm{~b}$ predicted that restrictive parental mediation would be a negative predictor of digital literacy. The results showed that restrictive parental mediation is negatively related to the level of digital literacy, $\beta=$ $.23, b=-.25, S E=.06, p<.001(95 \% \mathrm{BCI}=[-.333,-.125])$, whereas active parental

improvement of the fit: $\mathrm{X}_{2}(277)=869,408, \mathrm{p}<.001, \mathrm{CFI}=.90, \mathrm{RMSEA}=.05(95 \%[\mathrm{CI}]=[.05, .06])$. For this reason, and taking into account that some scholars reject this procedure (Hermida, 2015), we decided to retain the original model without error term correlations.

$$
\sim 176 \sim
$$


CHAPTER 7. STUDY 2. RELATIONSHIP BETWEEN PARENTAL MEDIATION AND ADOLESCENTS' DIGITAL SKILLS, ONLINE RISKS AND ONLINE OPPORTUNITIES

mediation has no relationship with it, $\beta=.06, b=.04, S E=.03, p=.21(95 \% \mathrm{BCI}=[-$ $.050, .158])$. Thus, hypothesis $2 \mathrm{a}$ is rejected, whereas hypothesis $2 \mathrm{~b}$ is confirmed.

\section{Hypothesis 3: Digital Literacy as a Mediating Variable}

Hypothesis 3 predicted that digital literacy would mediate the relation between parental mediation an online risks and online opportunities. Testing the indirect relationship between parental mediation and online risks and opportunities through digital literacy as a mediating variable (see Figure 13), we found that active parental mediation does not indirectly predict online risks, $\beta=.01, b=.00, S E=.00, p=.167$ $(95 \% \mathrm{BCI}=[-.005, .036])$ or online opportunities, $\beta=.04, b=.02, S E=.02, p=.298$ $(95 \% \mathrm{BCI}=[-.041, .120])$ through digital skills.

On the contrary, restrictive mediation is negatively related to both online risks, $\beta=-.03, b=-.02, S E=.01, p=.025(95 \% \mathrm{BCI}=[-.075,-.005])$ and online opportunities, $\beta=-.17, b=-.11, S E=.05, p=.001(95 \% \mathrm{BCI}=[-.270,-.093])$ through digital literacy.

To investigate the significance of the indirect relationships, we tested the model with nested-model logic under two conditions: one model in which the direct paths from parental mediation to online risks and online opportunities were allowed to vary, and one model in which these paths were constrained to zero. Since there is a non-significant difference between both model's fits, $\Delta \chi^{2}(2, N=715)=4.87, p=.09$, digital literacy fully mediates the effect of active and restrictive parental mediation on online risks and online opportunities. Therefore, hypothesis 3 is partially supported as digital literacy mediates the relation between restrictive parental mediation and online risks and online opportunities.

\subsection{Discussion}

Through this study, we aimed to examine the relationship between adolescents' digital skills and online risks and opportunities. As we hypothesised, and in consonance with 
previous studies, the more skilled teenagers are, the more online opportunities they take (S.-J. Lee \& Chae, 2012; Livingstone \& Helsper, 2010; Nikken \& Schols, 2015; Sonck \& de Haan, 2013). Likewise, the more skilled adolescents are, the more online risks they experience (S.-J. Lee \& Chae, 2012; Leung \& Lee, 2012b; Livingstone, Ólafsson, et al., 2017; Livingstone \& Helsper, 2010; Sonck \& de Haan, 2013; Staksrud et al., 2013).

The second aim of the present study was to examine the influence of two types of parental mediation (active and restrictive) on the level of teenagers' online opportunities and online risk behaviours, indirectly through digital skills. We found that adolescents' digital literacy mediates the influence of restrictive, but not of active, parental mediation on online risks and opportunities. Restrictive parental mediation reduces adolescents' digital skills, and as such reduces both their online risks as well as online opportunities.

Contrary to what some scholars believed digital skills do not reduce online risk behaviours. In fact, these skills predict both online risks and online opportunities. It is therefore necessary to look at other skills that adolescents may need to cope with online risks. Future research may therefore find a fruitful task in investigating the type of coping mechanisms that adolescents adopt, both offline and online, and what role parents, schools and peers can play herein. Some researchers have started to focus on resilience, as the ability to deal with negative experiences and display coping strategies, such as blocking the sender of unwelcome messages (e.g., insults; Vandoninck, d'Haenens, et al., 2013). However, research has predominantly focused on coping strategies for cyberbullying (Lam \& Frydenberg, 2009; Machackova et al., 2013; Machmutow et al., 2012; Riebel et al., 2009) and has not considered any of the other risks, such as encountering online violence and pornography, or talking to strangers. 
CHAPTER 7. STUDY 2. RELATIONSHIP BETWEEN PARENTAL MEDIATION AND ADOLESCENTS' DIGITAL SKILLS, ONLINE RISKS AND ONLINE OPPORTUNITIES

In any case, it has been found that the more digitally literate the children are, the more online coping strategies they use (Vandoninck et al., 2013). In this way, digital skills could have an indirect impact on dealing with online risks through developing coping skills. Moreover, the relationships between digital skills and online opportunities were stronger than those between digital skills and online risks. Consequently, the development of such skills remains essential in order that adolescents can take advantage of the maximum online opportunities. 



\section{Chapter 8.}

\section{STUDY 3.}

\section{DIGITAL LITERACY}

\section{INTERVENTION AND}

COPING STRATEGIES

DEVELOPMENT ${ }^{11}$

\subsection{Introduction}

esults from our previous study showed that more digitally skilled adolescents
take more opportunities, and experience more risks (Rodríguez-de-Dios et
al., 2018). Thus, digital skills are not effective for reducing online risks, but

" Part of this chapter has been submitted for publication and was under review at the time of this dissertation submission:

Rodríguez-de-Dios, I., Igartua, J.-J., \& d'Haenens, L. (2018). Narrative persuasion in mobile learning: Effectiveness of a mobile application for promoting online safety on adolescents. Manuscript submitted for publication. 
they remain essential since they let adolescents take more online opportunities. We concluded that, as adolescents spend more time online, they become more digitally literate, which may cause them to reap more benefits from digital technologies but also to experience more online risks.

In the study 2 , we measured, on a scale ranging from $1=$ never to $5=$ always, the frequency with which adolescents experience online risks. According to the results, contact with strangers was the most prevalent online risky behaviour: contact with strangers $(M=1.61, S D=.64)$, cyberbullying victim $(M=1.15, S D=.37)$, exposure to pornography $(M=1.33, S D=.59)$, exposure to violence $\left(M=1.26, S D={ }_{57}\right)$, cyberbullying perpetrator $(M=1.07, S D=.32)$. Previous studies in online risks have yielded similar results, as the most common risky activity reported by participants (European children aged 9-16) was also communicating with new people not met faceto-face (Livingstone, Haddon, Görzig, et al., 2011a). In our study, this factor was measured with five items ${ }^{12}$, whose frequency is reported in Figure 14. Results revealed that $25 \%$ of adolescents give info about themselves (address, phone number, etc.) to another person that they have not met face to face. Moreover, $53 \%$ of adolescents chat with people they meet online and $14 \%$ send pictures of themselves to people they meet online. Finally, $19.5 \%$ of young people meet face-to-face people that they have first met online and $66 \%$ add people that they have not met face to face to their social media sites.

In line with these results, a study with youths aged 12-17 (Liau et al., 2005) found that $16 \%$ of minors had met someone in real life that they first encountered online. Similarly, in another study, it was found that 5.6\% of teenagers (aged 10-13) meet face-to-face someone they only know online. Moreover, $12.8 \%$ of them add strangers to their friend lists and $2.9 \%$ send pictures or videos of themselves to people

${ }^{12}$ Items were transformed into dichotomous items, with 'Yes' representing always, often, sometimes or rarely, and 'No' representing never. 


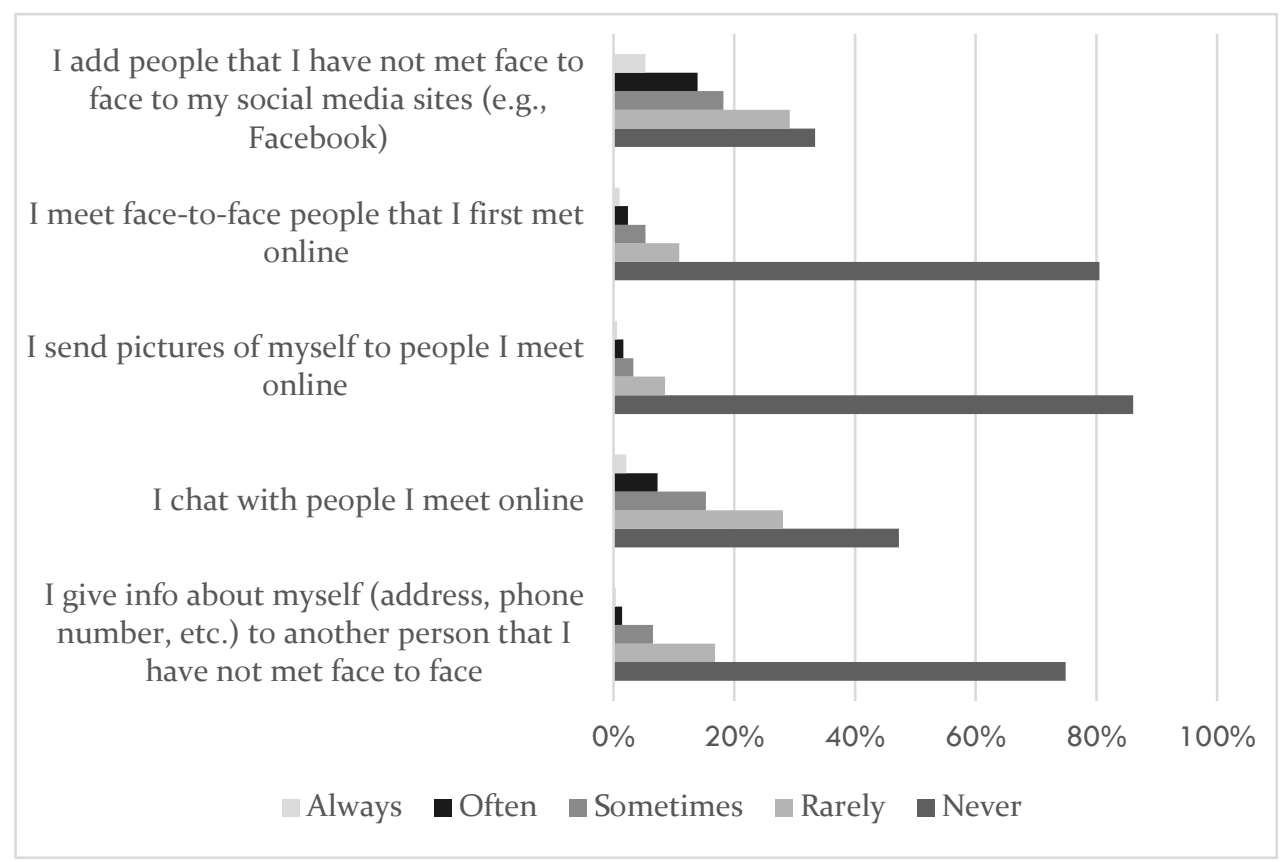

Figure 14. Frequency of online contact risks on adolescents

they meet online (Fernández-Montalvo, Peñalva, \& Irazabal, 2015). In the same way, in another survey, $13,6 \%$ of middle-school students (9-15 years) reported having had communication with someone known only to them from the Internet, $8 \%$ said that they had met their online stranger in person and $28 \%$ declared to post personal information on the Internet (Dowdell, 2011). Likewise, the study of Berson and Berson (2005), with adolescent girls aged 12 to 18 , revealed that $25 \%$ of participants send picture of self at request of someone on the Internet and $18 \%$ has met in person with someone who is an online acquaintance. Finally, the EU Kids Online study found that $30 \%$ of children aged 9-16 years old have made contact online with someone they previously did not know offline and $9 \%$ have met an online contact offline in the past year (Livingstone, Haddon, Görzig, et al., 2011a).

Due to the difficulty of reducing these risks, the use of coping strategies, such as blocking the sender (Vandoninck et al., 2013), has emerged as a key factor in this 
process. Research has shown that the negative impact of online risks can be mitigated by coping strategies (Raskauskas \& Huynh, 2015). Therefore, as we saw in Chapter 4 , teaching coping strategies for facing online risks to minors could be a solution.

Regarding parental mediation, in the previous study we found that restrictive mediation is negatively related to adolescent's digital skills and online opportunities. Restrictive mediation would diminish online risks through the reduction of digital skills. On the other hand, active mediation had no significant relationship with digital skills, online risks or online opportunities. Therefore, parental mediation would be ineffective for promoting digital skills or reducing online risks.

On the contrary, as we saw in the theoretical framework, educational interventions have proved to be an effective tool for promoting adolescents' digital safety (Chaux et al., 2016; Chibnall et al., 2006; Cross et al., 2016; Fernández-Montalvo et al., 2017; Gradinger et al., 2016; Ortega-Ruiz et al., 2012; Palladino et al., 2016; Vanderhoven et al., 2014a; Williford et al., 2013; Zhang-Kennedy et al., 2017). Similarly, the use of mobile learning has resulted in learning benefits and the enhancement of learning (Chee et al., 2017; Cheung \& Slavin, 2013; Stevenson \& Hedberg, 2017; Tingir et al., 2017; W.-H. Wu et al., 2012). Moreover, educational interventions through apps have been successful in promoting learning outcomes (Ahmed \& Parsons, 2013; BrizPonce et al., 2016; Diliberto-Macaluso \& Hughes, 2016; Jeno et al., 2017; Jou et al., 2016; Kiger et al., 2012; Ling et al., 2014; Noguera et al., 2013; Q. Wu, 2015; Yang et al., 2013; Yoo \& Lee, 2015) and it has been shown that mobile learning initiatives that use elements from constructivism and gamification have positive effects on knowledge achievement and motivation (Attali \& Arieli-Attali, 2015; Buckley \& Doyle, 2016; Çakıroğlu et al., 2017; Domínguez et al., 2013; Marzouki et al., 2017; Su \& Cheng, 2015). Finally, research has demonstrated that the use of narratives, compared to other formats, is more effective in changing attitudes and beliefs (Murphy et al., 2013). 
Therefore, given the limited number of intervention programmes available to address online risks, and specifically to address contact with strangers (the most frequent online risk), and the non-existence of mobile apps with this objective, we aim to develop a mobile application with the purpose of increasing coping strategies among adolescents for facing risks with online contact. Moreover, and considering the benefits of digital skills for promoting online opportunities, we also aim to increase digital skills among adolescents through this intervention. To develop this intervention, we will consider the constructivist, gamification, mobile learning and narrative theories. Therefore, the main goal of the present study is to develop a mobile application for teaching digital skills and coping strategies, and to evaluate the impact of its use on adolescents.

From this main goal, we set out the following specific research objectives:

- To develop a mobile application, considering the constructivist, gamification, mobile learning, and narrative theories.

- To assess the impact of the mobile app on the level of digital skills and the intention to use coping strategies for facing online contact risks.

- To analyse the predictor roles of mobile application acceptance, narrative transportation and identification for the impact of the app.

- To study the moderator role of gender and age of the participant for the impact of the app.

Considering the research previously mentioned, our first hypothesis states that the mobile application will have an impact on the development of the personal security digital skill and the intention to use active coping strategies (proactive coping and communicative coping) for facing online contact risks $\left(\mathrm{H}_{1}\right)$. 
Moreover, prior literature has suggested that narrative transportation and identification with characters are linked with reductions in counterarguing and increases in the story's persuasive effectiveness (Christy, 2017). Thus, it has been demonstrated that narrative transportation increases the persuasive impact (Green \& Brock, 2000; Mazzocco, Green, Sasota, \& Jones, 2010; Murphy et al., 2013, 2011). Similarly, identification with the character has been found to predict the impact of the narrative (de Graaf et al., 2012; Igartua \& Barrios, 2012; Igartua \& Frutos, 2017; Igartua \& Vega Casanova, 2016; Moyer-Gusé et al., 2011; Moyer-Gusé \& Nabi, 2010; Murphy et al., 2013). Furthermore, previous research has concluded that gamification and constructivism contents promote technology and mobile acceptance (Baptista \& Oliveira, 2017; Elwood, Changchit, \& Cutshall, 2006); and, at the same time, technological acceptance has been shown to predict the effectiveness of the educational content (Al-hawari \& Mouakket, 2010).

Consequently, our second hypothesis states that mobile application acceptance, narrative transportation and identification with the main character will predict the impact of the exposure to the app on the level of the personal security skill and the intention to use active coping strategies (proactive coping and communicative coping) for facing online contact risks $(\mathrm{H} 2)$. From this main hypothesis, we set the following subhypotheses:

Hza. Mobile application acceptance, narrative transportation and identification with the protagonist will predict the impact of exposure to the app on the level of the personal security skill.

Hzb. Mobile application acceptance, narrative transportation and identification with the protagonist will predict the impact of the exposure to the app on the intention to use active coping strategies. 
On another note, and considering individual characteristics, initiatives against online risks have shown that gender is not a moderator of the intervention effectiveness (Chaux et al., 2016; Gradinger et al., 2016; Palladino et al., 2016; Williford et al., 2013). As far as we know, only one study found significant differences between the impact on girls and boys (Chibnall et al., 2006). Similarly, mobile learning interventions have not found male-female differences in the effectiveness of the intervention (Jeno et al., 2017; Noguera et al., 2013; Teri et al., 2014).

Regarding the age of the participant, some studies have found that interventions against online risks have larger effects for those students from lower grades than from higher grades (Chibnall et al., 2006; Williford et al., 2013). As far as we one, only study found no differences between younger and older students (Gradinger et al., 2016). In this case, previous research is scarce since interventions (both mobile learning interventions and educational interventions against online risks) are usually tested on a sample composed of students at the same grade (Ahmed \& Parsons, 2013; Burgess \& Murray, 2014; Cross et al., 2016; Desmet et al., 2017; Fernández-Montalvo et al., 2017; Jeno et al., 2017; Kiger et al., 2012; Meilan et al., 2015; Palladino et al., 2016; Sandberg et al., 2011; Yang et al., 2013). In those cases, age comparisons were not possible.

At any rate, and considering previous results, we hypothesise that age will negatively moderate the impact of the app on the level of the personal security skill and intention to use active coping strategies (proactive coping and communicative coping) when facing contact online risks $\left(\mathrm{H}_{3}\right)$. Therefore, the impact of the app will be greater in younger than in older students. From this main hypothesis, we set the following subhypotheses:

H3a: Age will negatively moderate the effect of the app on the level of the personal security skill. 
$\mathrm{H}_{3} \mathrm{~b}$ : Age will negatively moderate the effect of the app on the intention to use active coping strategies.

With respect to the moderator role of previous experience of online risks on the effectiveness of the intervention, past research has shown that higher levels of online risks were related to a stronger effect of the intervention (Gradinger et al., 2016). Consequently, our fourth hypothesis states that frequency of contact with online risks will positively moderate the impact of the app on the level of the personal security skill and intention to use active coping strategies (proactive coping and communicative coping) when facing online contact risks $\left(\mathrm{H}_{4}\right)$. From this main hypothesis, we set the following subhypotheses:

H4a: Frequency of contact online risks will positively moderate the impact of the app on the level of the personal security skill.

$\mathrm{H}_{4} \mathrm{~b}$ : Frequency of contact online risks will positively moderate the impact of the app on the intention to use active coping strategies.

Regarding the characteristics of our mobile application, it allows users to choose between a male or a female character. This decision was made based on the result of a previous study (Woods, Hall, Dautenhahn, \& Wolke, 2007) in which it was found that there was a significant association between gender and prime character (which character within the scenario that the child would like to be). Accordingly, we hypothesise that there will be a significant association between gender and the character chosen. Girls will choose the female character, and boys will choose the male character $\left(\mathrm{H}_{5}\right)$. From this main hypothesis we set other two subhypothesis. First, as we hypothesise that there will be a significant relation between the gender of the participant and the character chosen, we posit that both genders will be identified with the protagonist and experience narrative transportation equally. In this sense, 
previous research has found that gender is unrelated to transportation (Green \& Brock, 2000; Mazzocco et al., 2010):

H5a: There will not be differences on the levels of identification with the character and narrative transportation between males and females.

From this subhypothesis, we also set the following subhypothesis:

H5b: There will not be differences on the levels of identification with the main character and narrative transportation considering the age of the participants.

Finally, one of the app's contents is a test which goal it is to advise the main character what to do in certain online situations (e.g., Today, I took a photo of me and my basketball team. For some of the players, today was their first day on the team. I'm going to share the photo in Instagram so everyone can see it. There is no need to ask anyone, ¿right?). Therefore, our last hypothesis posits that the score in the test and the level of the personal security skill and the intention to use active coping strategies after using the mobile application will be correlated (H6).

\subsection{Method}

\subsubsection{Participants}

Power analysis with $G^{*}$ Power (Faul, Erdfelder, Lang, \& Buchner, 2007) was conducted to determine the required sample size. Based on two meta-analysis of mobile learning research (Sung, Chang, \& Liu, 2016; Tingir et al., 2017) that reported mean effect sizes of 0.52 and 0.48 , we calculated the sample size for a medium effect size. Results indicated that a sample size of 128 participants would be needed to yield a power level of $.80(\alpha=.05)$.

Data were collected from 274 students of secondary education from $1^{\text {st }}$ to $3^{\text {rd }}$ grade at three different schools in Spain: one public and two (publicly funded) private 
schools (see Appendix 1). Students were between 12 and 16 years old, and their mean age was $13.22(S D=1.01)$. Moreover, $53.5 \%$ of participants were male and $46.5 \%$ were female.

The three participating schools were self-selected, responding to an invitation to participate in the research project (see Appendix 2). The online invitation to participate in the experiment was sent to four schools. Thus, $75 \%$ of the contacted schools agreed to participate. A consent form was sent to parents/carers of students in the participating schools (see Appendix 3). Students were asked to get these consent forms signed by their parents. Interventions were only conducted after obtaining the consent of the parent and the child. These forms briefly explained the nature of the study. Parents were assured that their children's answers would be treated anonymously, confidentially and used for scientific purposes only. They were also told that participation was voluntary and that children could stop their participation at any time and without consequences. Participants did not get any compensation for taking part in the study

Of the 274 participants, 29 were excluded from the analysis because of missing data (they participated at pre-test only or at post-test only, but not at both). Therefore, $11.7 \%$ of records were incomplete. In the end, 245 participants were retained for the analysis.

\subsubsection{Design and Procedure}

This study followed a quasi-experimental design, as adolescents were not randomly assigned to each of the conditions (Conde et al., 2013). When researching in schools, randomisation of students presents a challenge, as teachers and principals in the schools usually insist on keeping the class structure intact (Ahmed \& Parsons, 2013; Igartua, 2006; F. Martin \& Ertzberger, 2013; Sandberg et al., 2011). In this situation, what researchers try to do is to use two similar classes (e.g., one experimental group 
of $1^{\text {st }}$ grade and one control group of $1^{\text {st }}$ grade too). In our study, we asked principals in schools to have two classes, as similar as possible, for each grade: one being the control group and the other the experimental group.

Therefore, students were not randomly assigned to any of the groups. They were assigned to the control or to the experimental group by considering their original class. In this sense, the use of an experiment design allows researchers to evaluate the effects and, therefore, the effectiveness and the impact of an intervention. The design of two groups is the most elementary structure in an experimental design. In its most basic form, there is a group that receives the intervention (experimental group) and another group that does not receive it (control group; Igartua, 2006). Consequently, there were two groups of students from secondary education: the experimental group, who used the app, and the control group, with no intervention. The absence of randomisation means that the quasi-experiment is subject to concerns of internal validity. To tackle these concerns, researchers usually conduct pre-test questionnaires with relevant variables for checking that they are homogeneous and that there are not significant differences between groups (Briz-Ponce et al., 2016; Huang, Lin, \& Cheng, 2010; Igartua \& Frutos, 2017; Noguera et al., 2013). This pre-test measures can be included later in the comparative analyses as covariate variables (Igartua, 2006).

The research was conducted in two stages. First, in December 2017, the pretest questionnaire was administered in the three schools. The pre-test questionnaire (see Appendix 6) measured the following variables: digital personal security skill, online contact risk, coping strategies and sociodemographic data (gender, age and grade). Secondly, the quasi-experiment took place one month after administration of the pre-test (last week of January and first week of February 2018). The procedure was as follows: we went to the education centres during school time and we carry smartphones with us. As said previously, for the aim of the study, a mobile application was developed. Therefore, we rented 30 smartphones Samsung Galaxy S5 with 
Android $^{13}$ mobile operating system, and installed the app before the experiment (Sandberg et al., 2011). Thus, as in previous interventions with mobile applications (Briz-Ponce et al., 2016; Crawford et al., 2016; Kiger et al., 2012), we decided that participants would be given a mobile device. We chose to do this in order to avoid some problems:

- Problems of compatibility: students with iPhone or Windows Phone could not participate. Moreover, the app could not run in older versions of Android phones.

- Sampling error problems: students without mobile phone could not participate

- Time restrictions: we would employ too much time on installing the apps on the students' devices.

- Schools restrictions: Some schools could not have Wi-Fi connection and others may disallow children to bring their mobile phones to the school.

In their classrooms, the students in the experimental group used the app, whereas the control group did not receive any specific intervention and followed the usual programme of classes. They simply completed the post-test questionnaire at the beginning or at the end of their lesson. As in similar interventions with online risks (Vanderhoven et al., 2014a) or app interventions (Ahmed \& Parsons, 2013; Briz-Ponce et al., 2016; Jeno et al., 2017; Jou et al., 2016; Ling et al., 2014; F. Martin \& Ertzberger, 2013; Yang et al., 2013), the experimental group used the app during one session. Students were asked to use the mobile application freely and to interact with it for

${ }^{13}$ Android system was chosen because of two reasons: (1) Android devices have a more affordable price; (2) According to data from Kantar Worldpanel, in 2017, in Spain, Android was the market leader as it had the $92 \%$ of the market share. On the other hand, iOS has $7.5 \%$ of the market share and Windows Phone only the $0.5 \%$. 
approximately 30 minutes. At the end of the session, they also completed the post-test questionnaire (see Appendix 7). This measured the following variables: digital security skill, coping strategies, mobile application acceptance, identification with the protagonist, narrative transportation and socio-demographics (gender, age and grade). In the case of the control group, their questionnaire (see also Appendix 7) only measured three variables: digital security skill, coping strategies and socio-

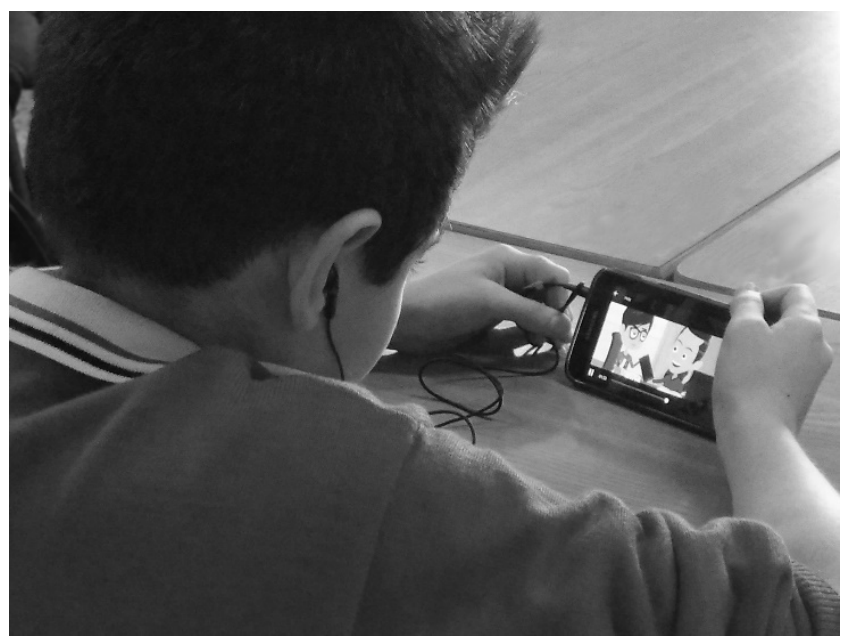

Figure 15. Student using the app during the intervention

demographical information (gender, age and grade). A more detailed description of these variables will be presented in the measures section.

8.2.3. Materials: Development of the Mobile Application (CompDig) and Pilot Study

CompDig ${ }^{14}$ is a mobile application intended to teach digital skills and active (proactive and communicative) coping strategies for facing online contact risk (contact with strangers). We decided to focus on this type of online risk because, as we said previously, this is the most common type of online risk. Furthermore, interventions

${ }^{14}$ CompDig - Competencias Digitales is available for free in Google Play (link). 
against online risks usually focus on cyberbullying (Desmet et al., 2017; Palladino et al., 2016; Salmivalli, Kärnä, \& Poskiparta, 2011). Similarly, we decided to teach only active and not passive (indifference/passive and avoidance) coping strategies for two reasons:

- Research has shown that active strategies are more effective than passive coping strategies (Machmutow et al., 2012). They are a better response as they are intended to reduce or eliminate harm in the future.

- We consider that stop using the Internet or going away from device cannot be a solution considering all the benefits that the use of digital technologies can have. Moreover, passive strategies "may further reduce their capacities for resilience and online opportunities" (Vandoninck et al., 2012, p. 209).

Finally, and with reference to digital skills, it would have been interesting to teach all of them through the app. However, it seemed a too ambitious and unattainable goal considering the characteristics of our experiment (schools would not have allowed us to spend more time conducting the experiment). Therefore, we focused on personal security skill (as some of the items are related to active coping strategies). The mobile application design was based on several theoretical frameworks: narratives, gamification and constructivist theories. An entire description of the contents of the mobile application is included in the Appendix 5 .

In the mobile application, there are three modules: my story, test and achievements completed. When entering the app (see Figure 16), the user can choose the character they want to use. There is a female character (Lucía) and a male character (Hugo). We decided to include two gender-versions of the same character because previous research found that that there is a significant association between gender and prime character (Woods et al., 2007). Contents are the same in both versions, and only the gender of the protagonist (and his/her friends) changes. 


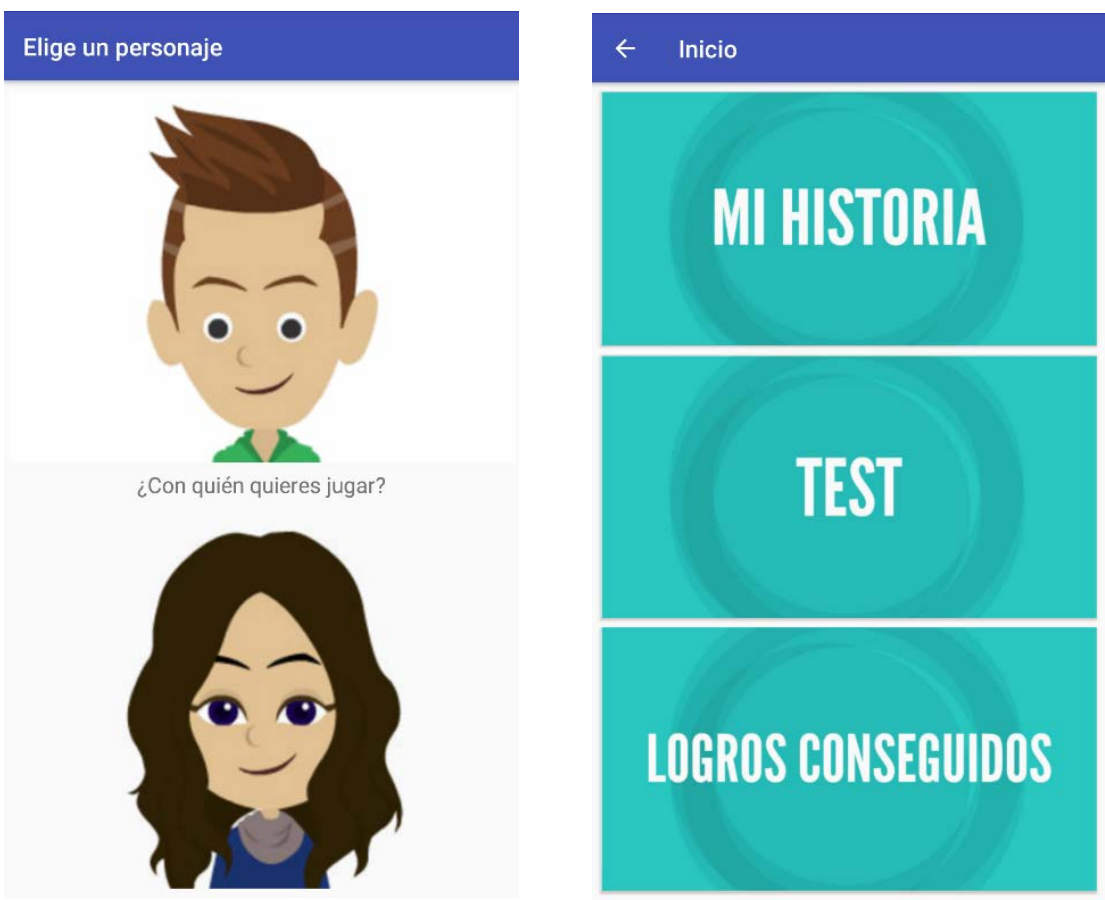

Figure 16. Snapshot of the character selection and the menu screens

First, and regarding the story module, stories follow a first person testimonial narrative format, as this has been found to be more effective (Christy, 2017; de Graaf, Sanders, \& Hoeken, 2016; H. K. Kim \& Shapiro, 2016). This module contains four animated videos created with the platform GoAnimate. In those stories, the protagonist speaks about their experiences using digital devices while giving pieces of advice related to coping strategies and digital skills. As said previously, stories were the same for both protagonists (same plots, settings and dialogues), the only difference between the two versions is the gender of the characters.

Secondly, the test module was developed considering gamification and constructivism theories. This module contains two different tests ("Aconseja a Hugo/Lucía” and “CCómo protejo mi información en la red?”). In these tests, users have 
to advise the main character what to do in certain online situations. According to Vanderhoven et al. (2014a), principles of constructivism can be applied with elements such as active exercises in which participants must choose an option. In the app, they receive feedback related to their answers. Furthermore, as stated by constructivism (Cooperstein \& Kocevar-Weidinger, 2004; Sandberg et al., 2011), learners construct their knowledge by integrating new knowledge with previous knowledge. Additionally, and according to the authenticity principle, we should choose activities that stimulate real-life situations. Therefore, in the narratives and in the tests, we refer to common life situations on social media that they will probably have experienced. Moreover, and according to gamification, which consists of adding game elements and principles to non-gaming contexts with the aim of enhancing motivation, users receive positive feedback ("great", "well done", etc.) when they give the correct answer (Khaleel et al., 2016).
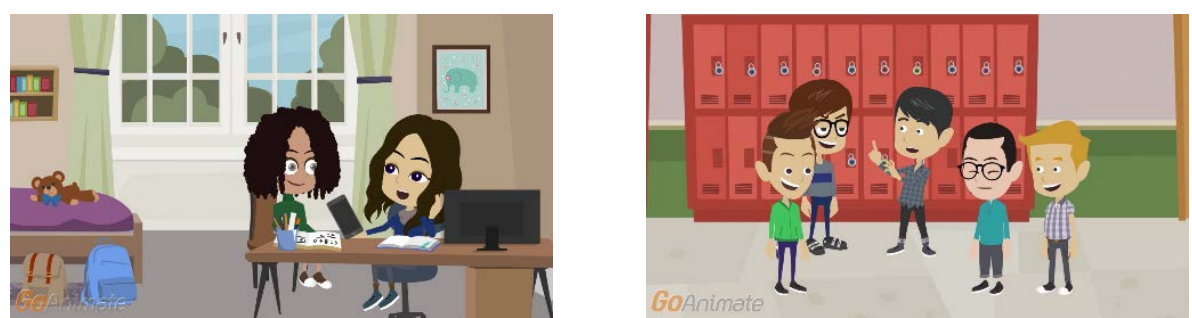

Figure 17. Scenes of the videos from the mobile application

Third, the achievements completed module has also been developed according to gamification principles. The app has a system of points and badges, with users receiving points for answering correctly, and badges for watching the stories and having good marks in the tests.

Finally, and following principles of constructivism, users can choose the order in which they complete the different modules. Moreover, and with the aim of having more relevant data to analyse, users in the quasi-experiment had to include the same 


\section{CompDig}

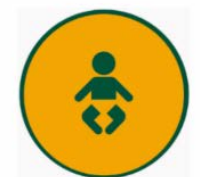

Prineipiante

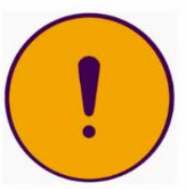

Eres un erack

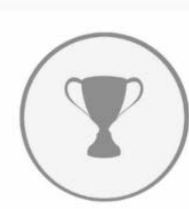

Usuario avanzado

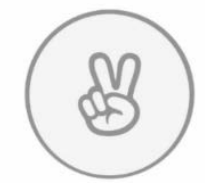

¡Historia completada!

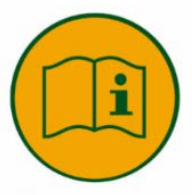

Gran consejero

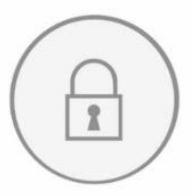

Experto en seguridad

Figure 18. Snapshot of the achievements completed screen

secret code that they included in the pre-test and post-test questionnaires. Through this code we could know which character they had chosen and which mark they had obtained in the tests.

A pilot study was carried out to test the realism and credibility of the narratives, and the degree of identification with the protagonist and narrative transportation experienced. This trial study was conducted with the participation of 16 students in secondary education $(56.3 \%$ male and a mean age of 15.25 years [ $S D=$ .57]) from a different school (not any of the participating schools in the intervention).

Participants in the pilot study were distributed into two groups divided by gender. Each group read the same story but with a different protagonist. Male participants read a story in which a boy (Hugo) was the protagonist, and female 
RISKS OF INTERACTIVE COMMUNICATION IN ADOLESCENTS.

DIGITAL LITERACY DIAGNOSIS AND INTERVENTION

participants read the same story, but with a female protagonist (Lucía). After reading the story, participants completed a short questionnaire. The first question asked (six items on a 5 -point Likert-type scale from $1=$ not at all to $5=$ very much) to what extent they had been identified with the protagonist (e.g., "I understood the main character's feelings or emotions"). The second question (four items on a 5-point Likert-type scale from $1=$ not at all to $5=$ very much) measured the degree of narrative transportation (e.g., "I was mentally involved in the narrative while watching it"). Finally, in the remaining question (six items on a 7-point Likert-type scale from 1 = strongly disagree to 7 = strongly agree), adolescents indicated to what extent they considered that the story they had read was realistic and credible.

The results of the pilot study showed that, while reading the story, participants were identified with the protagonist $(M=3.52 ; S D=.68)$, both in the case of male $(M=3.48 ; S D=.65)$ and female students $(M=3.57 ; S D=.76)$. Moreover, students experienced narrative transportation $(M=2.96 ; S D=.55)$. A one sample TTest was conducted to determine whether the sample mean was statistically different from the hypothesized population mean. Both sample means were higher than the normal score (2.5): identification with the main character, $t(15)=20.54, p<.001$, and narrative transportation, $t(15)=21.4, p<.001$.

Regarding the realism and credibility of the story, participants considered that "The message was clear and understandable" $(M=6.13 ; S D=1.08)$, "The story was credible" $(M=6.19 ; S D=.65)$, "The story was interesting" $(M=6.13 ; S D=1.02)$, "The story about Hugo/Lucía was realistic" $(M=6.00 ; S D=1.21)$, "The story told by Hugo/Lucía made sense" $(M=6.25 ; S D=1.00)$ and "The story portrayed situations that could occur in real life" $(M=6.69 ; S D=.60)$. 


\subsubsection{Measures}

Personal security skill: This skill was assessed with four items from the Digital Literacy Scale (Rodríguez-de-Dios, Igartua, \& González-Vázquez, 2016; Rodríguez-de-Dios et al., 2018). Items were measured with a 5-point Likert scale of self-reported agreement, responses ranging from $1=$ strongly disagree to $5=$ strongly agree (e.g., "I know when I can post pictures and videos of other people online"). This variable was measured both in the pre-test $(\mathrm{M}=4.28, \mathrm{SD}=0.77$; Cronbach's $\alpha=.66)$ and the post-test $(\mathrm{M}=$ 4.45, $\mathrm{SD}=0.71 ; \alpha=.73)$.

Online contact risks: It was measured with five items from a previous study (Rodríguez-de-Dios et al., 2018). On a scale ranging from $1=$ never to $5=$ always, participants reported on how often they engage in certain activities online related to contact with strangers (e.g., "Send personal pictures to people I meet online"). An index was created by taking the mean of the separate items $(\alpha=.66 ; M=1.34, S D=$ 0.45).

Coping strategies: Four types of coping strategies (proactive, communicative, passive and avoidance) were assessed with 12 items from a scale of coping strategies (Vandoninck \& d'Haenens, 2015). Items measured on a scale ranging from $1=\mathrm{I}$ did not/would not do this, to $4=$ I would probably do this. Participants were asked how they (would) respond to the online contact risks. As stated by previous studies on coping with online risks, it "makes sense to ask non-victimized children how they (hypothetically) would deal with such issues" (Vandoninck \& d'Haenens, 2015, p. 227). These variables were measured both in the pre-test and the post-test: proactive (pretest $[M=3.03, S D=0.63 ; \alpha=.50]$; post-test $[M=3.39, S D=0.56 ; \alpha=.56]$; e.g., "Change privacy settings"); communicative (pre-test $[M=2.30, S D=0.67 ; \alpha=.30]$; post-test [ $M$ $=2.65, S D=0.70 ;, \alpha=.43]$; e.g., "Talk with friend(s)"); passive (pre-test $[M=1.88, S D$ $=0.77$; $\mathrm{r}$ de Pearson $\left.{ }^{15}=.23\right]$; post-test $[M=1.72, S D=0.74, r=.34]$; e.g., "Don't care 
about what happened"); and avoidance (pre-test $[M=2.04, S D=0.80 ; \alpha=.72]$; posttest $[M=1.78, S D=0.83 ; \alpha=.82]$; e.g., "Go offline for a while"). Mean scores are based on the variables that were created by taking the mean of the separate items.

Mobile application acceptance: This was assessed using seven items adapted from previous studies (Lund, 2001; Nikou \& Economides, 2017; Noguera et al., 2013). The scale was designed to measure satisfaction with the app and the contents, and ease of use (e.g., "I would like to use this app again"). Items were measured with a 5point Likert scale ranging from $1=$ strongly disagree to $5=$ strongly agree. An index of mobile application acceptance was created by making a mean score of the seven items $(M=4.35, S D=0.54 ; \alpha=.78)$.

Identification with the protagonist: This was assessed with a short-version of the Identification with the Protagonist Scale (Igartua \& Barrios, 2012). The adapted scale consisted of six items and it was designed to measure in retrospect the participants' identification with the protagonist, Lucía or Hugo (e.g., "I felt as if I were the main character") with possible responses ranging from $1=$ not at all to $5=$ extremely. An index of identification with the protagonist was created based on calculating the average of the scores for the six items $(M=3.66, S D=0.81 ; \alpha=.81)$.

Narrative transportation: This was assessed with the Transportation ScaleShort Form (TS-SF; Appel, Gnambs, Richter, \& Green, 2015). As in previous studies (Riedl, 2010; Sangalang et al., 2013), mental imaginary items designed for the narrative format (e.g., "While reading the narrative I had a vivid image of the character") were excluded. The scale consisted of 4 items (e.g., "I wanted to learn how the narrative ended"; ranging from $1=$ not at all to $5=$ extremely). An index of narrative transportation was created by making a mean score of the items $(M=3.03, S D=0.93$; $\alpha=$.74). 


\subsubsection{Data Analysis}

Data were analysed using SPSS 22 and the PROCESS macro for SPSS (Hayes, 2013).

\subsection{Results}

\subsubsection{Preliminary Data Analysis: Equivalence of the Experimental Groups}

Before analysing the data, we checked the homogeneity of the two groups (control and experimental) with respect to the following variables: personal security skill, online contact risks and coping strategies (four types: indifference/passive coping, avoidance coping, communicative coping and proactive coping).

Table 22.

Homogeneity of the groups: experimental and control.

\begin{tabular}{llllll}
\hline Variable & Group & $\mathrm{M}$ & $\mathrm{SD}$ & $\mathrm{t}$ & $P$ \\
\hline \multirow{2}{*}{ Personal Security Skill } & Experimental group $(N=126)$ & 4.11 & .84 & & \\
& Control group $(N=118)$ & 4.44 & .66 & 3.30 & .001 \\
& Experimental group & 1.26 & .37 & & \\
Online Contact Risks & Control group & 1.40 & .51 & & \\
& Experimental group & $3.56^{16}$ & .011 \\
Proactive Coping & Control group & .65 & & \\
\multirow{2}{*}{ Communicative Coping } & Experimental group & 3.04 & .62 & .35 & .723 \\
& Control group & 2.34 & .64 & & \\
Passive Coping & Experimental group & 2.26 & .70 & & \\
& Control group & 1.86 & .74 & & \\
Avoidance Coping & Experimental group & 1.91 & .81 & .44 & .658 \\
& Control group & 2.19 & .82 & & \\
\hline
\end{tabular}

${ }^{16}$ In this variable, Levene's test is significant at $\mathrm{p}<$. .o1. Therefore, we used the test statistics for 'Equal variances not assumed'. 
RISKS OF INTERACTIVE COMMUNICATION IN ADOLESCENTS.

DIGITAL LITERACY DIAGNOSIS AND INTERVENTION

The independent-samples Student's t-test was used to check that both groups were homogeneous. Results showed that there were no statistically significant differences between the groups in some of the variables considered. However, in other variables there were statistically significant differences (see Table 22). For this reason, in the following statistical analysis, we include pretest as a covariate.

In Table 23, we can see the demographic characteristics of both groups. We also examined whether there were any significant differences between the groups in participants' demographic characteristics. Chi-square analyses showed that they did not differ significantly regarding gender, $\chi^{2}(1, N=245)=.629, p=.428$, or grade, $\chi^{2}(2$, $N=245)=.317, p=.853$. Moreover, the Student's t-test indicated that there were no statistically significant in the age of the participants between the experimental group ( $M$ $=13.16, S D=1.00)$ and the control group $(M=13.28, S D=1.02) ; t(243)=.885, p=.377$.

\section{Table 23.}

Distribution of demographic characteristics

\begin{tabular}{|c|c|c|c|c|}
\hline \multirow[b]{2}{*}{ Demographic variables } & \multicolumn{2}{|c|}{ Experimental } & \multicolumn{2}{|c|}{ Control } \\
\hline & $\mathrm{N}$ & $\%$ & $\mathrm{n}$ & $\%$ \\
\hline \multicolumn{5}{|l|}{ Gender } \\
\hline Male & 60 & 50.8 & 71 & $55 \cdot 9$ \\
\hline Female & 58 & 49.2 & 56 & 44.1 \\
\hline \multicolumn{5}{|l|}{ Grade } \\
\hline $\mathbf{1}^{\circ} \mathrm{ESO}$ & 42 & 35.6 & 49 & 38.6 \\
\hline $2^{\circ}$ ESO & 28 & 23.7 & 27 & 21.3 \\
\hline \multirow[t]{2}{*}{$3^{\circ} \mathrm{ESO}$} & 48 & 40.7 & 51 & 40.2 \\
\hline & $\mathrm{M}$ & SD & $\mathrm{M}$ & SD \\
\hline Age & 13.16 & 1.00 & 13.28 & 1.02 \\
\hline
\end{tabular}




\subsubsection{Hypotheses Testing}

Hypothesis 1: Impact of the mobile application on the development of the personal security digital skill and the intention to use active coping strategies

With the aim of testing the impact of the mobile application, we conducted an analysis of covariance (ANCOVA) using the pretest as a covariate ${ }^{17}$ (see Table 24). Results showed that the mobile application was effective as the level of personal security skill was significantly higher in the experimental group than in the control group. Furthermore, students from the experimental group showed a greater intention to use active coping strategies (proactive and communicative) than the other students did. Similarly, participants from the experimental group showed a lower intention to use passive coping strategies than the participants from the control group (see Figure 19).

Hypothesis 2: Mobile application acceptance, narrative transportation and identification with characters as predictors of the impact of the app

Our second hypothesis stated that mobile application acceptance, narrative transportation and identification with the main character would predict the impact of the exposure to the app on the personal security skill and the intention to use active coping strategies (proactive coping and communicative coping) for facing online contact risks $(\mathrm{H} 2)$.

Before conducting the analysis, we conducted a preliminary analysis for checking the levels of mobile application acceptance $(M=4.35, S D=.54)$, of identification with the protagonist $(M=3.67, S D=.81)$, and of narrative transportation $(M=3.03, S D=.93)$. We also conducted a one sample T-Test to determine whether the sample mean was statistically different from the hypothesized population mean.

${ }^{17}$ We included the following variables measured in the pretest as covariate in the analysis: personal security skill, proactive coping, communicative coping, passive coping and avoidance coping. 
RISKS OF INTERACTIVE COMMUNICATION IN ADOLESCENTS.

DIGITAL LITERACY DIAGNOSIS AND INTERVENTION

All the sample means were higher than the normal score (2.5): mobile application acceptance, $t(117)=86.75, p<.001$; identification with the main character, $t(117)=$ 49.05, $p<$.001; and narrative transportation, $\mathrm{t}(117)=35.40, p<.001$. Results showed a high level of acceptance and good levels of identification with the protagonist and narrative transportation.

Table 24.

Impact of the mobile application on the level of personal security skill and on the intention to use coping strategies.

\begin{tabular}{|c|c|c|c|c|c|c|c|}
\hline \multirow{2}{*}{ Variable } & \multirow{2}{*}{ Group } & \multicolumn{2}{|c|}{ Post-test } & \multirow{2}{*}{$F$} & \multirow{2}{*}{$p$} & \multirow{2}{*}{$\eta_{p}^{2}$} & \multirow{2}{*}{$\begin{array}{l}d \\
\text { (Cohen's) }\end{array}$} \\
\hline & & $M$ & $S D$ & & & & \\
\hline \multirow{2}{*}{$\begin{array}{l}\text { Personal } \\
\text { Security Skill }\end{array}$} & Experimental & $4 \cdot 72$ & .38 & \multirow[b]{2}{*}{33.9} & \multirow[b]{2}{*}{$<.001$} & \multirow[b]{2}{*}{.124} & \multirow[b]{2}{*}{.76} \\
\hline & Control & 4.24 & .80 & & & & \\
\hline \multirow{2}{*}{$\begin{array}{l}\text { Proactive } \\
\text { Coping }\end{array}$} & Experimental & 3.61 & .49 & \multirow{2}{*}{$41 \cdot 3$} & \multirow{2}{*}{$<.001$} & \multirow{2}{*}{.150} & \multirow{2}{*}{.89} \\
\hline & Control & 3.18 & .47 & & & & \\
\hline \multirow{2}{*}{$\begin{array}{l}\text { Communicative } \\
\text { Coping }\end{array}$} & Experimental & 2.89 & .72 & \multirow{2}{*}{28.8} & \multirow{2}{*}{$<.001$} & \multirow{2}{*}{.110} & \multirow{2}{*}{.70} \\
\hline & Control & 2.42 & .61 & & & & \\
\hline \multirow{2}{*}{$\begin{array}{l}\text { Passive } \\
\text { Coping }\end{array}$} & Experimental & 1.56 & .69 & \multirow{2}{*}{9.8} & \multirow{2}{*}{.002} & \multirow{2}{*}{.040} & \multirow{2}{*}{-.41} \\
\hline & Control & 1.86 & .76 & & & & \\
\hline \multirow{2}{*}{$\begin{array}{l}\text { Avoidance } \\
\text { Coping }\end{array}$} & Experimental & 1.45 & .66 & \multirow{2}{*}{41.1} & \multirow{2}{*}{$<.001$} & \multirow{2}{*}{.147} & \multirow{2}{*}{-.83} \\
\hline & Control & 2.08 & .85 & & & & \\
\hline
\end{tabular}



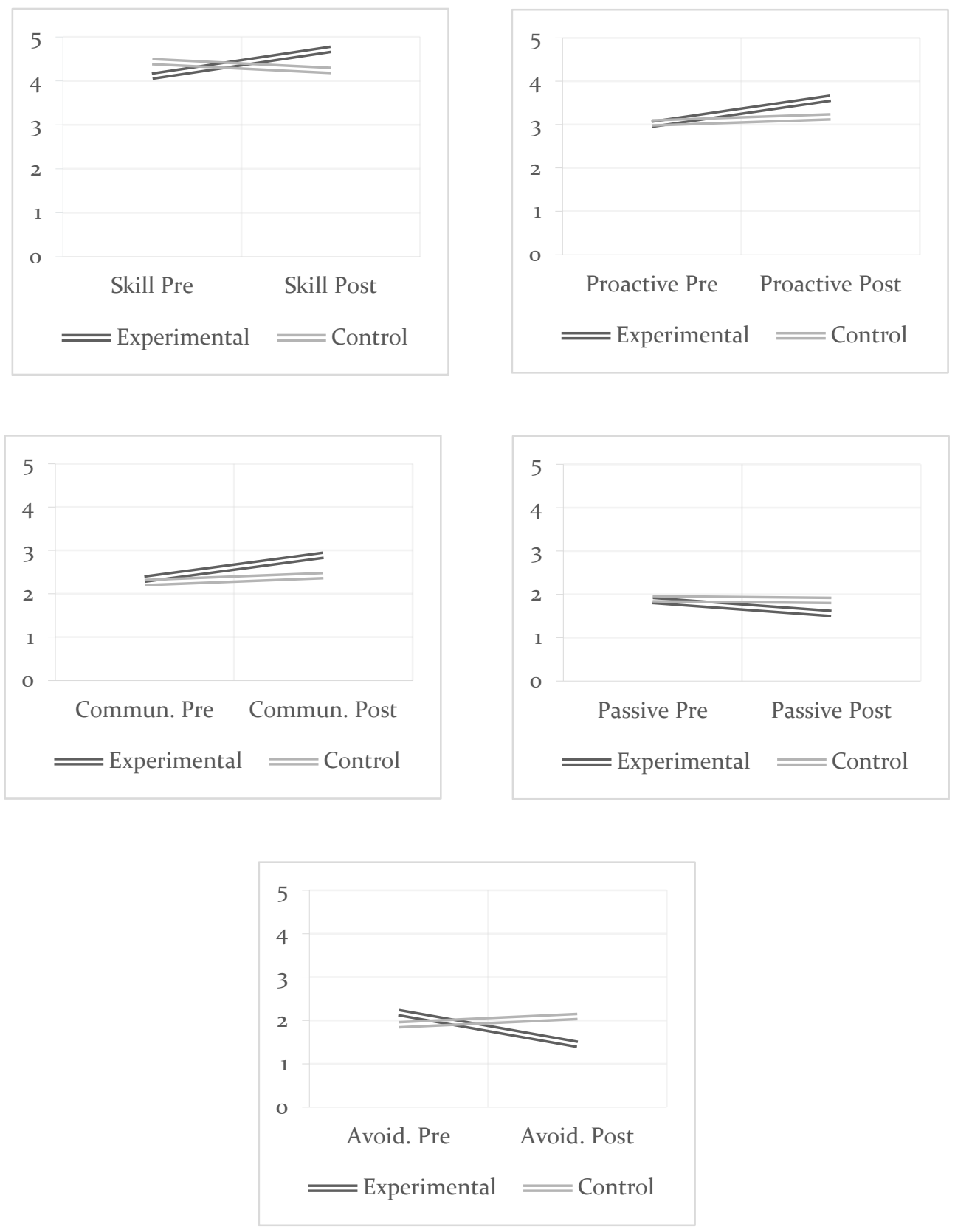

Figure 19. Differences between the control and the experimental group on pre-test and post-test 
To test hypothesis 2, and the subhypotheses derived from it, we conducted multiple regression analyses. Moreover, the analyses were conducted using only the experimental sample. The multiple regression analysis allows the researcher to estimate the relationships between a dependent variable and two or more independent variables. Therefore, this is a useful technique to assess the effects of several independent variables on a single dependent variable (Igartua, 2006). In the analysis, the independent variables were mobile application acceptance, narrative transportation and identification with characters. The dependent variables were the personal security skill (in the first analysis) and the active coping strategies (in the second and third analyses). Moreover, these same variables measured in the pre-test were introduced in the analysis as covariate. Results of the analysis can be seen in Table 25.

In this table, results of the multicollinearity test, measured by the value of tolerance, are also presented. They indicate no multicollinearity within the independent variables. However, there is a high correlation between the three independent variables: identification with the character and narrative transportation $(\mathrm{r}=.60, p<.001)$; identification with the character and mobile application acceptance $(\mathrm{r}=.59, p<.001)$; and narrative transportation and mobile application acceptance $(\mathrm{r}=$ $.41, p<.001)$. Therefore, results should be interpreted with caution.

First, and with reference to the predictor role of those variables on the impact of the app on the level of the personal security skill ( $\mathrm{H} 2 \mathrm{a})$, it was observed that mobile application acceptance was the only variable that had a statistically significant effect on the level of personal security skill after the intervention. On the contrary, identification with characters and narrative transportation had no effect on this skill. This regression only explained $6.2 \%$ of the variance in the level of the personal security skill. Therefore, $\mathrm{H} 2 \mathrm{a}$ is partially supported. 
Table 25 .

Multiple linear regression analyses for personal security skill and active coping strategies

\begin{tabular}{|c|c|c|c|c|}
\hline & $\begin{array}{c}\text { Personal } \\
\text { Security Skill }\end{array}$ & $\begin{array}{l}\text { Proactive } \\
\text { Coping }\end{array}$ & $\begin{array}{c}\text { Communicative } \\
\text { Coping }\end{array}$ & \\
\hline & $\beta$ & $\beta$ & $\beta$ & Tolerance \\
\hline $\begin{array}{l}\text { Mobile app } \\
\text { acceptance }\end{array}$ & $.314^{* *}$ & -.015 & -.106 & .64 \\
\hline $\begin{array}{l}\text { Identification } \\
\text { with } \\
\text { characters }\end{array}$ & .011 & $.390^{* *}$ & $.411^{* * *}$ & .49 \\
\hline $\begin{array}{l}\text { Narrative } \\
\text { transportation }\end{array}$ & -.178 & -.136 & .048 & .63 \\
\hline $\mathrm{F}(g l)$ & $2.94(4,113)$ & $3.84(4,113)$ & $5.09(4,113)$ & \\
\hline$p$ & .023 & .006 & .001 & \\
\hline$R$ (Adjusted $\left.R^{2}\right)$ & $.307(.062)$ & $.346(.088)$ & $.391(.123)$ & \\
\hline
\end{tabular}

Regarding the predictor role of those same variables on the impact of the app on the intention to use active coping strategies, that is, proactive and communicative coping $\left(\mathrm{H}_{2} \mathrm{~b}\right)$, results suggest that identification with characters is positively associated with the intention of use these strategies. For proactive coping strategies, $8.8 \%$ of variance is explained by this regression model. In the case of communicative coping strategies, $\mathbf{1 2 . 3} \%$ of variance is explained. Consequently, $\mathrm{H}_{2} \mathrm{~b}$ is also partially supported.

Therefore, $\mathrm{H}_{2}$ is partially confirmed by the data, as narrative transportation is not a predictor of the impact of the mobile application. However, in one of the variables, mobile app acceptance acts as a predictor; in the other two variables, identification with characters is the predictor. 
Hypothesis 3: Age ${ }^{18}$ as a negative moderator of the impact of the app

Hypothesis 3 stated that age would negatively moderate the impact of the app on the level of the personal security skill and the intention to use active coping strategies (proactive coping and communicative coping) when facing contact online risks. To test this hypothesis, and the subhypotheses derived from it, we used the PROCESS macro (model 1) developed by Hayes (2013), which is based on multiple linear regression (moderated multiple regression).

This model allowed us to test if there was an interaction effect between the impact of the app and the age of the participant on the level of the skill or on the intention to use active coping strategies. Variables in the pre-test (personal security skill and active coping strategies) were introduced into the models as a covariate variable.

It was observed that the interaction effect between the use of the app and the age on the level of personal security skill was not statistically significant $(B=-.01, S E$ $=.08, p=.892)$. Therefore, the impact of the app on this skill was not moderated by the age and $\mathrm{H}_{3} \mathrm{a}$ is not supported by the data. Similarly, the interaction effect between the use of the app and the age on the intention to use proactive coping strategies ( $\left.\mathrm{H}_{3} \mathrm{~b}_{1}\right)$ was not statistically significant $(B=-.03, S E=.06, p=.618)$. On the contrary, there was a significant interaction effect $(B=-.16, S E=.08, p<.05)$ between the use of the app and the age on the intention to use communicative coping strategies $\left(\mathrm{H}_{3} \mathrm{~b}_{2}\right)$.

The impact of the use of the app on the intention to use communicative coping strategies is stronger in the younger students Thus, the app has a greater impact on 12 year old $(B=.62, p<.001)$ and 13 year old $(B=.45, p<.001)$ than on the 14 year old students $(B=.28, \mathrm{p}<.05)$. Moreover, using the Johnson-Neyman technique,

\footnotetext{
${ }^{18}$ It is important to note that we have a short age range in the sample (12-16 years old). Therefore, results related to the age should be interpreted with caution.
}

$$
\sim 208 \sim
$$


we calculated the critical value in the moderating variable (age) after which the effect of the mobile application on the intention to use communicative coping strategies was no longer statistically significant (see Figure 20). That value was 14.4 and this means that for those adolescents older than 14.4 years old, using the app did not induce greater intention to use such coping strategies.

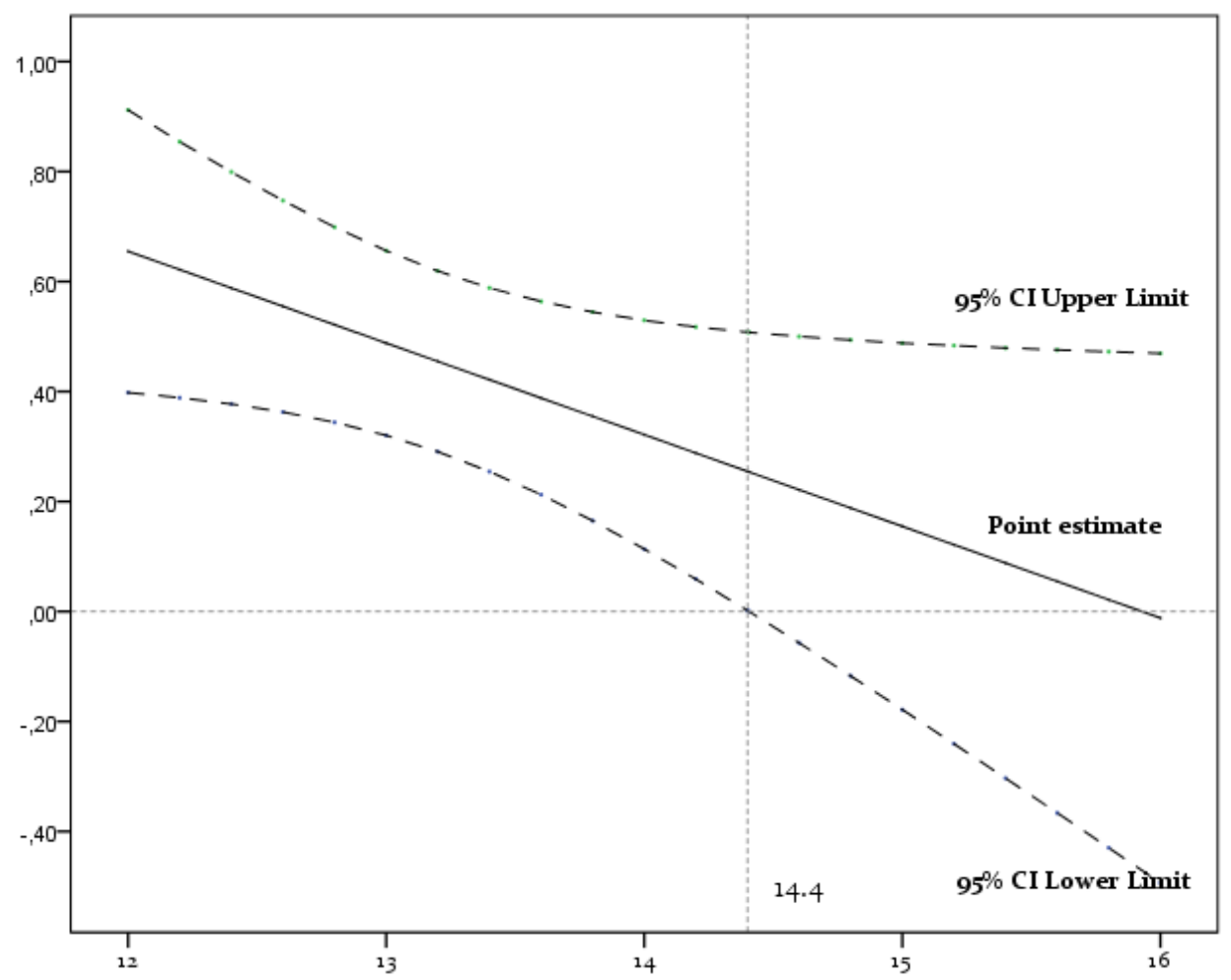

Figure 20. Johnson-Neyman regions of significance for the conditional effect of the use of the mobile application on the intention to use communicative coping strategies at levels of age

We decided to also test the moderator role of gender on the impact of the app on the level of personal security skill and on the intention to use active coping strategies. It was found that the interaction effect between the use of the app and the gender on the level of personal security skill was not statistically significant $(B=-.11$, 
$S E=.17, p=.501)$. Similarly, the interaction effects between the use of the app and the gender on the intention to use proactive coping strategies $(B=-.07, S E=.13, p=.604)$, and communicative coping strategies $(B=-.03, S E=.17, p=.836)$ were not statistically significant. Consequently, the impact of the app on the intention to use active coping strategies was not moderated by gender.

In view of the above, the impact of the mobile application on the level of personal security skills and on the intention to use active coping strategies (proactive coping and communicative coping) when facing contact online risks was not moderated neither by the age nor the gender of the participant. Age only moderated the impact of the app on the intention to use communicative strategies.

Hypothesis 4: Effect of the frequency of online contact risks as a positive moderator of the impact of the app

Hypothesis 4 posited that the frequency of online contact risks would positively moderate the impact of the mobile application on the level of the personal security skill and on the intention to use active coping strategies (proactive coping and communicative coping) when facing online contact risks. This hypothesis, and the subhypotheses derived from it, was again tested using the PROCESS macro (model 1) developed by Hayes (2013). Moreover, the analyses were conducted using only the experimental sample.

The first subhypothesis referred to the moderator role of online contact risks on the impact of the app on the level of the personal security skill ( $\left.\mathrm{H}_{4} \mathrm{a}\right)$. Results showed that the impact of the app on this skill was not moderated by the frequency of online contact risks $(B=.10, S E=.20, p=.613)$ and $\mathrm{H}_{4}$ a is not confirmed.

The second subhypothesis referred to the moderator role of online contact risks on the impact of the app on the intention to use active coping strategies $\left(\mathrm{H}_{3} \mathrm{~b}\right)$. Results showed that the interaction effects between the use of the app and the 
frequency of online contact risks on the intention to use proactive coping strategies $(B=.23, S E=.15, p=.144)$, and communicative coping strategies $(B=.19, S E=.20, p=$ .322) were not statistically significant ( $\mathrm{H}_{4} \mathrm{~b}_{1}$ and $\left.\mathrm{H}_{4} \mathrm{~b}_{2}\right)$. Consequently, $\mathrm{H}_{4} \mathrm{~b}$ is also rejected.

In view of the above, hypothesis 4 is not supported empirically. Results showed that the impact of the mobile application on the level of personal security skill and on the intention to use active coping strategies was not moderated by the frequency with which participants encounter online contact risks.

Hypothesis 5: Relationship between gender and character chosen

Hypothesis 5 stated that there would be a significant association between gender and the character chosen by the adolescents when using the mobile application. Girls will choose the female character, and boys will choose the male character. To test this hypothesis, a chi-square analysis was conducted using only the experimental sample. Chi-square analysis showed that there were gender differences when it came to choosing the character, $\chi^{2}(1, N=118)=99.582, p<.001$. Therefore, $91,7 \%$ of boys chose the male character in the app while $100 \%$ of the girls chose the female one. Consequently, hypothesis 4 is confirmed.

Similarly, $\mathrm{H}_{5}$ a posited that there would not be differences on the levels of identification with the character and narrative transportation between males and females. To test this hypothesis, an independent-samples Student's t-test was employed using only the experimental sample to explore the relationship between gender and identification with the character and narrative transportation.

Results showed that there were not statistically significant differences either in the level of identification with the character between male participants $(M=3.53$, $S D=.91)$ and female participants $(M=3.81, S D=.66)$; $\mathrm{t}(116)=-1.891, p=.061$; or in the level of narrative transportation between male participants $(M=3.04, S D=.99)$ and 
RISKS OF INTERACTIVE COMMUNICATION IN ADOLESCENTS.

DIGITAL LITERACY DIAGNOSIS AND INTERVENTION

female participants $(M=3.02, S D=.87) ; \mathrm{t}(116)=.141, p=.888$. Consequently, $\mathrm{H}_{5} \mathrm{a}$ is supported by the data.

Likewise, hypothesis $5 \mathrm{~b}$ stated there would not be differences on the levels of identification with the character and narrative transportation considering the age of the participants. To test this hypothesis, a Pearson's correlation was conducted to explore the relationship between gender and identification with the character and narrative transportation. Results showed that age was correlated with the level of

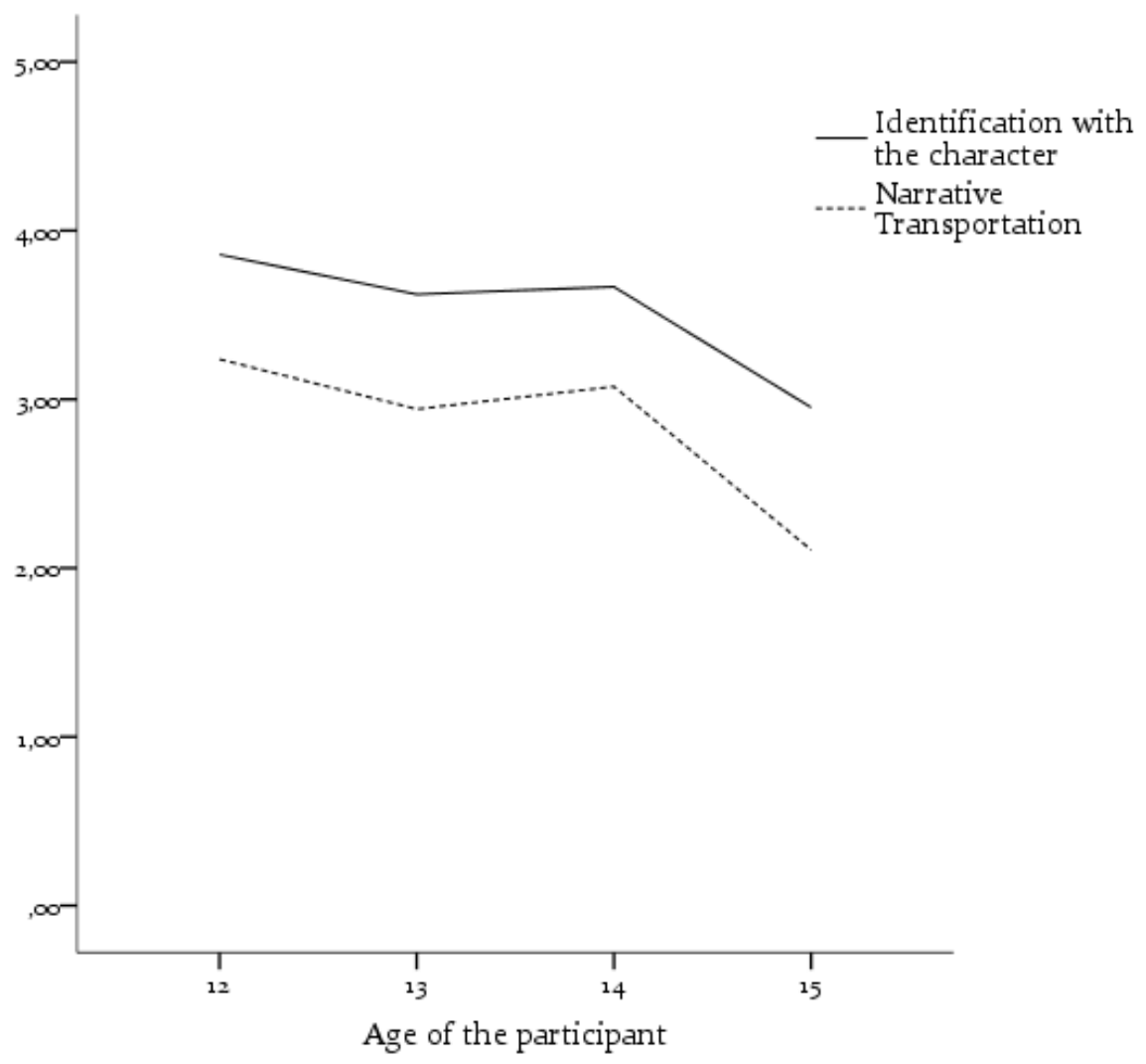

Figure 21. Identification with the protagonist and narrative transportation considering the age of the student. 
identification with the protagonist $(r=-.23, p<.005)$ and the level of narrative transportation $(r=-.21, p<.005)$. As we can see in Figure 21 , the younger the participant, the higher the level of identification with the main character and the level of narrative transportation. Consequently, $\mathrm{H}_{5} \mathrm{~b}$ is not confirmed.

Finally, the last hypothesis (H6) posited that the score in the test of the app and the level of the personal security skill and the intention to use active coping strategies would be correlated. Nonetheless, the score obtained in the test was not correlated neither with the level of the personal security skill $(r=-.01, p=.935)$ nor with the intention to use active coping strategies: proactive $(r=.17, p=.064)$ or communicative $(r=.06, p=.493)$. Consequently, hypothesis 6 is not supported.

\subsection{Discussion}

The present study designed a mobile application and investigated its impact on the development of digital skills and coping strategies on adolescents. Regarding the impact, results showed statistically significant differences between both groups. Participants in the experimental group had higher levels of personal security skills than participants in the control group. Similarly, adolescents that used the mobile application showed a greater intention to use active coping strategies (proactive and communicative) and a lower intention to use the passive ones (passive and avoidance) compared to adolescents in the control group. Effect sizes, considering Cohen's d statistic, were moderate (for communicative coping and personal security skill) to large (for proactive coping). The findings of the study allow us to conclude that the use of mobile learning and new technologies are an effective intervention tool to improve digital safety on adolescents.

With reference to the predictor role of narrative transportation on the impact of the app, contrary to what was hypothesised, results showed that this variable had no significant effect. Levels of narrative transportation were not high, but they are within range of some previous studies that had significant effects (Mazzocco et al., 
2010). However, results showed that there was a negative correlation between the amount of narrative transportation and the age of the participant. It could be the case that the older participants may interpret the stories as a childish content. Moreover, a small percentage of the students were mentally involved in the narrative while watching it, and this could influence the results. It could be the case that the conditions of the experiment procedure, with students sitting next to each other in their current classrooms, have limited the amount of narrative transportation experienced. This is in line with a meta-analysis that showed that distraction reduces transportation but has little to no effect on identification (Tukachinsky, 2014). Furthermore, research has shown that the use of first-person narratives does not influence the level of transportation (de Graaf et al., 2012; Tukachinsky, 2014), but can result in greater identification with the character (de Graaf et al., 2012). Therefore, the use of a non-choral and first-person narrative with a main character in our study may have not promoted narrative transportation, but may have promoted the identification of the audience with the main character. At any rate, the fact that this has been the potential predictor variable with the lowest level may have negate any potential effect it may had had on the impact of the app.

On the contrary, identification with the protagonist was found to be a predictor variable of the impact of the intervention on the intention to use active coping strategies. Results are consistent with previous research on identification with characters (de Graaf et al., 2012; Igartua \& Barrios, 2012; Igartua \& Frutos, 2017; Igartua \& Vega Casanova, 2016; Moyer-Gusé et al., 2011; Moyer-Gusé \& Nabi, 2010; Murphy et al., 2013). Nonetheless, it should be note that this process only explained the impact on the intention to use active coping strategies. On the contrary, it did not influence the impact of the application on the development of the personal security digital skill. Considering that the development of this skill was predicted by mobile application acceptance, it could be the case that other elements from the app (such as the contents 
from the test module) influenced this development. The persuasive content of the message transmitted by the protagonist would have only influenced the use of coping strategies.

In any case, these variables only explain between the $5 \%$ and the $12 \%$ of the variance on the dependent variables. Findings suggest that they might be other potential predictor variables that also explain the impact of the mobile application.

On the other hand, our study confirms that gender do not moderate the impact of mobile learning interventions on digital safety. These results are consistent with previous research on mobile learning (Chaux et al., 2016; Gradinger et al., 2016; Jeno et al., 2017; Noguera et al., 2013; Palladino et al., 2016; Teri et al., 2014; Williford et al., 2013) and they support the fact that the use of mobile learning for promoting digital safety seems to be equally effective for both females and males. Similarly, the present study suggests that neither the age nor the frequency of online risks moderate the impact of the mobile application on the educational outcomes. Age only predicted the impact of the app on the intention to use communicative coping strategies. However, it should be noted that one of the items of these variables refers to talk with parents about the online contact risk situation. This item has a strong correlation with the age of the adolescent (the younger the minor, the more likely to use this strategy). According to developmental studies, when entering the adolescence, children and parents start to spend less time together and they have less communication (Montemayor, 1983; Steinberg \& Morris, 2001). Adolescents want independence and prefer to talk about these issues with their peers. Therefore, the result of our study could have been determined by this developmental issue. At any rate, the results of our study encourage the use of mobile learning on adolescents since its effectiveness has been verified regardless of their individual characteristics.

Furthermore, results confirmed a significant association between gender and the character chosen by the adolescents when using the mobile application. These 
results shed light on the importance of creating characters of both genders when developing educational interventions for young people using narratives. Since all the girls chose the female character and most of the boys chose the male character, we could not check whether there were differences on the level of identification with the protagonist when the gender of the participant and the gender of the character were different.

Finally, results showed that the score in the test of the mobile application and the level of the personal security skill and the intention to use active coping strategies were not correlated. However, as we said previously, the development of the personal security digital skill was related to mobile acceptance. Therefore, two different things could have happened: (1) gamification and constructivism elements of the test were not as successful as we thought and did not influence mobile acceptance and the development of this skill (2) when using the app, if adolescents did not give the correct answer, a message would appear explaining to them the correct answer. Consequently, it could be that they got a low score in the test, but they learnt about safety online through the responses of the test.

With respect to the implications of the study, as far as we know this is the first study that develops and test the impact of a mobile application on the development of digital skills and coping strategies for facing online risks on adolescents. It also makes a significant contribution to research into narrative persuasion on the area of digital safety. Traditionally, studies on narrative persuasion have focused on the power of narratives for health communication (M. Chen et al., 2016; de Graaf, 2014; de Graaf et al., 2016; Frank, Murphy, Chatterjee, Moran, \& Baezconde-Garbanati, 2015; Jensen, Yale, Krakow, John, \& King, 2017; H. K. Kim \& Shapiro, 2016; Murphy et al., 2011), for reducing social stigma (Christy, 2017; Igartua \& Frutos, 2017; Igartua, Guerrero-Martín, et al., 2018) and, more recently, for campaigns on gender violence (Igartua \& Fiuza, 2018). This research shows that narratives can also be effective for promoting safe and 
responsible use of digital technology. Moreover, these narratives can be successfully integrated in mobile learning initiatives.

In conclusion, the findings of the present study suggest that the use of mobile learning with narrative contents is an effective tool to improve digital safety on adolescents, regardless of their gender or age. 



\section{Chapter 9.}

\section{DISCUSSION AND}

\section{GENERAL CONCLUSIONS}

I n recent years, adolescents have increased their use of information and communication technology. Consequently, this has sparked discussion about the

risks and opportunities that digital technologies may have for adolescents. Given these concerns about online risks and online opportunities, the different stakeholders involved, such as parents, educators, policymakers and researchers, aim to find the best possible solution in this situation. As parents play an important role in adolescents' development, their role in mediating the use of such technology is questioned. Moreover, some researchers argue that the best way to increase online opportunities and avoid online risks is to increase adolescents' digital skills. Therefore, some researchers have focused their attention on digital literacy and digital skills.

\subsection{Overview of the Study}

With this doctoral thesis, we aimed to improve digital skills in adolescents so that they can afford, without danger, the risks of interactive communication and can maximise the opportunities that this communication gives to them. With this overall goal, we set four specific objectives: (a) to create a methodological tool to assess the level of 
RISKS OF INTERACTIVE COMMUNICATION IN ADOLESCENTS. DIGITAL LITERACY DIAGNOSIS AND INTERVENTION

digital skills of a population; (b) to analyse which factors influence the level of digital skills, online risk behaviours and online opportunities; (c) to determine whether there is a relationship between digital skills and online risk behaviours; and (d) to develop an intervention, using a mobile application based on the entertainment-education strategy and theories of narrative persuasion, to promote digital literacy. Accordingly, this thesis has been conducted through two processes (and three studies): the first process being to perform a diagnosis of digital skills, and the second process being an intervention to promote digital literacy.

Therefore, the main aim of the first study in the thesis project was to provide a reliable and valid scale to assess the level digital literacy among adolescents. Consequently, we developed and validated the Digital Literacy Scale.

By conducting exploratory factor analysis on the first half of the data, six digital skills were identified in the study. These categories are quite similar to those proposed in the theoretical framework. Thus, we first proposed a model composed of five digital skills: (a) technological skill, (b) security skill, (c) critical skill, (d) informational skill, and (e) communication skill. Results supported the multidimensionality of digital literacy, but they showed a six-dimensional structure: (a) technological skill, (b) personal security skill, (c) device security skill, (d) critical skill, (e) informational skill, and (f) communication skill. Consequently, the factor that was originally set as security skill was divided into two security categories: personal and device. Although both factors relate to security, this division seems logical, since protecting digital devices from potential threats, such as viruses, may not involve protecting identity and personal information online. Otherwise, the instrument resembles the model originally proposed.

The structural and the cross-population validities of the Digital Literacy Scale were corroborated by two confirmatory factor analyses conducted using the second half of the data. A confirmatory factor analysis supported the structure of the scale, 
composed of six digital skills. A second-order confirmatory factor analysis showed that the six factors were related to a higher-order dimension (digital literacy). Although the model fit of the factor analyses were just short of the recommended criteria, we can argue that the factor structure of the scale is clear and stable.

Following previous literature, we checked the convergent validity of the scale through the correlation of the different skills with the attitude to technology and technology anxiety scales. As the scale showed a strong correlation with both variables (positive with attitude to technology and negative with technology anxiety), concurrent validity was satisfactory.

Consequently, the Digital Literacy Scale was found to be reliable and valid. As we shall see in the next sections, despite some room for improvement in the scale, it seems to be a valid and reliable instrument for use in future studies related to digital literacy and adolescents.

Through the second study in this doctoral thesis, we aimed to examine the relationship between parental mediation (active and restrictive), adolescents' digital skills, and online risks and opportunities. First, as we hypothesised, results showed that the more skilled teenagers are, the more online opportunities they take and the more online risks they experience. Secondly, results suggested that restrictive parental mediation is negatively related to adolescents' level of digital literacy, whereas active parental mediation has no relationship with it. Finally, we found that adolescents' digital literacy mediates the influence of restrictive, but not of active, parental mediation on online risks and opportunities. Restrictive parental mediation reduces adolescents' digital skills and, as such, reduces both their online risks as well as online opportunities.

Therefore, digital skills positively predicted both online risks and online opportunities. As adolescents spend more time online, they become more digitally literate, which may cause them to reap more benefits from digital technologies, in 
RISKS OF INTERACTIVE COMMUNICATION IN ADOLESCENTS.

DIGITAL LITERACY DIAGNOSIS AND INTERVENTION

terms of communication, entertainment and multi-media purposes. Moreover, through these skills and these online opportunities adolescents would be able to avoid digital exclusion.

It seems to be an unavoidable circumstance that becoming more digitally literate also increases the chances of experiencing online risks. At the same time, the associations between digital skills and online opportunities are stronger than those between digital skills and online risks. Likewise, digital skills do not explain much of the variance in online risks. This suggests that there may be other - and stronger predictors of online risks. This also seems plausible when looking at the type of online risks measured in this study. Exposure to sexually explicit or violent content is predicted by many (offline) factors, such as personal interest and sensation seeking (Doornwaard, van den Eijnden, Baams, Vanwesenbeeck, \& ter Bogt, 2016; Doornwaard, van den Eijnden, Overbeek, \& ter Bogt, 2015; Slater, 2003), pubertal timing (Beyens et al., 2015), or peer norms and pressure (Vanden Abeele et al., 2014), and thus may not always depend on adolescents' digital skills. Moreover, experiencing cyberbullying is often highly associated with experiencing offline bullying (Beran \& Li, 2007; Kowalski, Morgan, \& Limber, 2012; Waasdorp \& Bradshaw, 2015), and may thus also not depend as much on digital skills.

On another note, we found that restrictive parental mediation is negatively related to the level of digital skills. In brief, the more frequently adolescents perceive their parents to engage in restrictive mediation of their online media use, the less digitally skilled they are. These results suggest that restrictive mediation is not the most appropriate type of mediation because, by restricting adolescents' use of digital media, we are limiting their development of digital skills too. Previous research has shown that restrictive mediation is related to a reduction of online risks and online opportunities (Daud et al., 2014; S.-J. Lee, 2012; S.-J. Lee \& Chae, 2012; Livingstone, Ólafsson, et al., 2017), but it has not considered the role of digital literacy in that

$$
\sim 222 \sim
$$


connection. Our study shows that restrictive mediation would diminish online risks through the reduction of digital skills.

Contrary to previous research (Duerager \& Livingstone, 2012), active mediation has no significant indirect relationship with online risks and opportunities through digital skills. One explanation could be that parents are often also not digitally literate themselves (Dincer, 2012; Terras \& Ramsay, 2016). When parents engage in active mediation, this may perhaps attest to an overall supporting bond between parents and children which has been associated with overall avoidance of risk behaviour and positive development in adolescence (Buijzen \& Valkenburg, 2005; V. H. H. Chen \& Chng, 2016; Clark, 2011). However, active mediation may not have much to do with children actually learning from their parents how to engage with digital technology. Relatedly, digital technologies may call for new forms of parental mediation. In line with this notion, 'participatory learning' has been suggested as a new strategy for active mediation and involves parents and children learning digital skills by jointly interacting with digital media. In this case, parents would be listeners and co-creators who invite their children to serve as leaders and guides of experiences with digital media (Clark, 2011).

Therefore, through restrictive mediation and the control of adolescents' activities and time online, parents are holding back the development of digital skills. This seems logical, as parents are not really teaching their children how to use digital devices or how to protect their digital identity; they are just checking their children's messages or preventing them from visiting certain sites. However, it seems that active parental mediation could have a positive effect on adolescents' digital skills. Through this type of mediation, parents try to provide their children with guidance and advice in the use of digital media (e.g. explaining why some websites are good or bad, or suggesting ways to use digital devices safely). Nonetheless, our results show that active mediation has no relationship with digital skills. It may be the case that parents are not digitally literate themselves and, therefore, not able to teach their children digital 
RISKS OF INTERACTIVE COMMUNICATION IN ADOLESCENTS. DIGITAL LITERACY DIAGNOSIS AND INTERVENTION

skills. Traditionally, a major part of the responsibility for children's online safety has been attributed to parents (Sonck \& de Haan, 2014). Nonetheless, as we can conclude, parental mediation of digital media may not be as effective as we tend to think.

Furthermore, the indirect impact of restrictive parental mediation through digital skills is more pronounced for online opportunities than online risks. This means that restrictive parental mediation would be reducing online risks mostly at the expense of online opportunities. As Sonck \& de Haan (2014) argue, parents need to understand that risks exist and that these risks are part of the increasingly digital lifestyles of young people. Restricting the use of digital media for fear of risks is limiting and affects the development of skills and opportunities for teenagers.

In brief, the main conclusions from the second study are: (a) digital skills do not reduce online risks but, on the contrary, they are positively related to them; (b) digital skills remain essential as they are associated with online opportunities; (c) restrictive mediation reduces digital skills and, as such, reduces both online risks and online opportunities; that is, restrictive mediation would diminish online risks through the reduction of digital skills.

Finally, the third study aimed to develop and evaluate a mobile application intended for the improvement of digital skills and active coping strategies in adolescents. Results suggested that the application was effective, since its use raised the levels of personal security skill and intention to use active coping strategies (proactive and communicative) when facing online contact risks. As a result, adolescents in the experimental group showed statistically significant higher levels of digital personal security skills, and of intention to use active strategies than participants in the control group. At the same time, adolescents that used the mobile app showed statistically significant lower levels of intention to use passive strategies (passivity and avoidance) compared to those that did not use it. 
Furthermore, and regarding the hypotheses, some interesting findings emerged. The first hypothesis stated that mobile application acceptance, narrative transportation and identification with the main character would predict the impact of the app. Even though previous research has demonstrated that narrative transportation increases persuasive impact (Green \& Brock, 200o; Mazzocco et al., 2010; Murphy et al., 2013), our results showed that narrative transportation was not a predictor of the impact of the mobile application. It must be noted that this was the potential predictor variable with the lowest predictive level. This may have negated any potential effect it may have had on the impact of the mobile application. As we shall see, conditions of the experiment procedure or characteristics of the narrative may have influenced the levels of narrative transportation and, consequently, its null predictive value.

On the contrary, and according to previous research (de Graaf et al., 2012; Igartua \& Barrios, 2012; Igartua \& Frutos, 2017; Igartua \& Vega Casanova, 2016; MoyerGusé et al., 2011; Moyer-Gusé \& Nabi, 2010; Murphy et al., 2013), results suggested that identification with characters predicts the impact of the app on intention to use active coping strategies. Consequently, the higher the level of identification with the character (Hugo or Lucía), the higher the intention to use proactive or communicative coping strategies. Nevertheless, identification with characters did not predict the impact of the app on the development of personal security skill.

On the other hand, the level of mobile acceptance predicted the impact of the app on the development of this skill, but not on intention to use active coping strategies. This raises the question whether different elements of the application had different outcomes. It seems that the narratives were more effective for increasing the intention to use active coping strategies. Consequently, the educational content transmitted by the main character would have been more efficient for teaching active coping strategies than for teaching personal security skill to young people. Moreover, as mobile acceptance only predicted the impact on the development of personal 
RISKS OF INTERACTIVE COMMUNICATION IN ADOLESCENTS. DIGITAL LITERACY DIAGNOSIS AND INTERVENTION

security skill, it seems that other elements of the mobile application rather than the narratives were successful for this purpose. Accordingly, the content of the test and of the badge modules, that is, the content developed in consideration of constructivism and gamification theories, would have been more efficient for teaching such skill.

At any rate, as we mentioned before, these predicted variables only explained between $5 \%$ and $12 \%$ of the variance of the dependent variables. This raises the question whether there may be other predictor variables that we did not consider in the study.

Our second hypothesis stated that age, but not gender, would moderate the impact of the app. Findings showed that the mobile application was as effective for boys as for girls, following previous results (Chaux et al., 2016; Gradinger et al., 2016; Jeno et al., 2017; Noguera et al., 2013; Palladino et al., 2016; Teri et al., 2014; Williford et al., 2013). Moreover, and contrary to previous research (Chibnall et al., 2006; Williford et al., 2013), age did not moderate the impact of the app. That is, the mobile application was as effective for the younger participants as for the older ones. There is one exception, though, which is the moderator effect of age on the relationship between using the app and intention to use communicative coping strategies. As we mentioned before, the fact that one of the items in this variable referred to talking to parents about risky online situations may have influenced this result. During adolescence, children have less communication with their parents and spend less time with them (Montemayor, 1983; Steinberg \& Morris, 2001). This may be the reason why age only moderates the effect of the app on this coping strategy, and not on the rest of the variables. Consequently, we could argue that the mobile application was effective regardless of age, as this result could be explained by the presence of the item related to parents.

Furthermore, previous experience with online contact risks did not moderate the impact of the app on both the development of personal security skill and active 
coping strategies. That is, the mobile application was effective regardless of the frequency with which young people have encountered online risks previously.

Finally, results suggested that adolescents tended to choose a character of their own gender. There was a significant relationship between adolescents' gender and the character chosen. Girls tended to choose Lucía, and boys tended to choose Hugo. This finding follows previous research (Woods et al., 2007) and raises the importance of creating both male and female characters when developing educational narratives for young people.

In brief, the main conclusions from the third study are: (a) the mobile application was effective, since its use raised the level of the personal security skill and intention to use active coping strategies when facing online contact risks; (b) identification with the main character and mobile acceptance predicted the impact of the app, but narrative transportation did not do so; and (c) in general, the mobile application was effective regardless of the individual characteristics of the adolescent.

\subsection{Implications for Theory and Research}

This study provides several theoretical and empirical contributions to the study of adolescents' digital literacy. First, we have validated the Digital Literacy Scale. Despite some room for improvement in the measurement, we argue that, even in its current state, this is a valid and reliable instrument for measuring digital skills in teenagers and, as such, fills a gap in the field of digital literacy research. It is a self-report scale that could be useful in large scale data collection and has demonstrated good convergent validity along with good reliability for most digital skills. Therefore, we consider that this scale is a valuable and useful contribution to digital literacy research.

Secondly, as far as we know, this thesis represents the first attempt to analyse how adolescents' digital skills mediate the influence of parental mediation on online 
RISKS OF INTERACTIVE COMMUNICATION IN ADOLESCENTS.

DIGITAL LITERACY DIAGNOSIS AND INTERVENTION

risks and online opportunities. Therefore, our study has important implications for this field, as the results show that parents are not actively contributing to their children's development of digital skills and subsequent effective use of digital devices and online opportunities. Consequently, this study provides new insights into how adolescents can make use of their digital environments in a beneficial way, and how parents can play a role herein.

Additionally, the present study builds a theoretical model explaining the mediation role of adolescents' digital skills in the relationship between parental mediation and online risks and opportunities (see Figure 22). Previous studies have only focused on the influence of parental mediation on online risks and opportunities and very few of these studies have evaluated the impact of this mediation on adolescents' digital skills. Therefore, our research helps us understand how digital skills have a mediating role between (restrictive) parental behaviours and adolescents' online experiences that previous studies have not addressed.

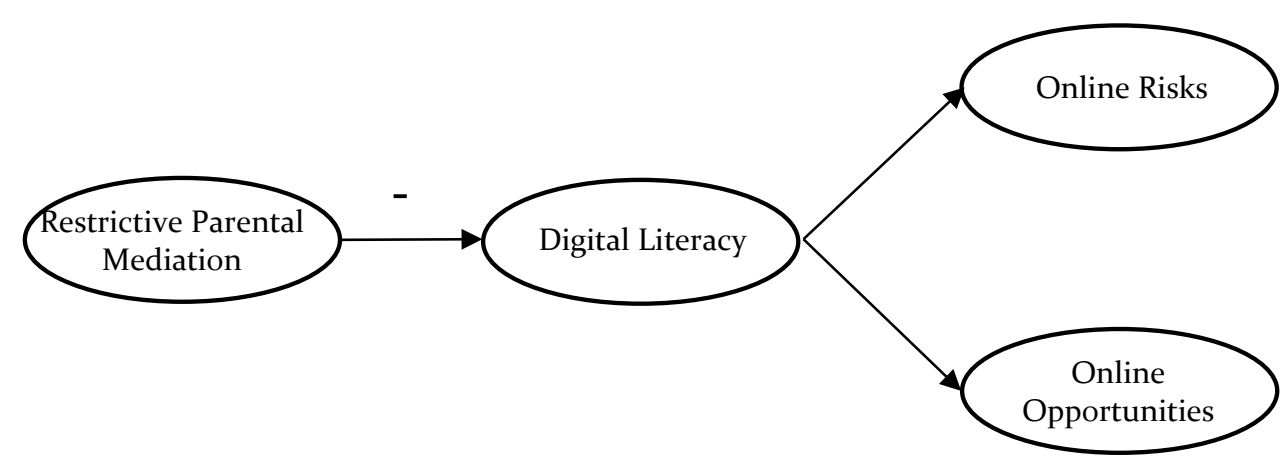

Figure 22. Theoretical model developed in the second study

On the other hand, as far as we know, the present thesis represents the first attempt to combine the use of traditional narrative persuasion with mobile learning. Results of the third study showed that this can be a successful combination for educational outcomes. Considering that adolescents spend great amounts of time 
using their smartphones, these results open a line of research that deserves further attention.

Furthermore, this study adds to previous evidence showing that identification with characters predicts the effects of narrative persuasion (de Graaf et al., 2012; Fitzgerald \& Green, 2017; Igartua, 2010; Igartua \& Barrios, 2012; Igartua \& Frutos, 2017; Igartua \& Vega Casanova, 2016; Moyer-Gusé et al., 2011; Murphy et al., 2013) and that narratives are effective for changing behaviours. In this sense, previous studies on narrative persuasion have focused on the power of narratives for health communication (M. Chen et al., 2016; de Graaf, 2014; Frank et al., 2015; Jensen et al., 2017; H. K. Kim \& Shapiro, 2016), for reducing social stigma (Christy, 2017; Igartua \& Frutos, 2017; Igartua, Guerrero-Martín, et al., 2018) and, more recently, for campaigns on gender violence (Igartua \& Fiuza, 2018). This thesis also makes a significant contribution to research into narrative persuasion showing that it can also be effective for promoting online safety and developing digital literacy in young people.

Finally, the present study also has important implications for mobile learning, as the results show that the application of this theory can be effective regardless of adolescents' individual characteristics. Previous studies had shown that mobile learning is equally effective for both females and males (Chaux et al., 2016; Gradinger et al., 2016; Jeno et al., 2017; Noguera et al., 2013; Palladino et al., 2016; Teri et al., 2014; Williford et al., 2013). However, the role of age was not clear as interventions have usually been tested on a sample composed of students at the same grade (Ahmed \& Parsons, 2013; Burgess \& Murray, 2014; Cross et al., 2016; Desmet et al., 2017; Fernández-Montalvo et al., 2017; Jeno et al., 2017; Kiger et al., 2012; Meilan et al., 2015; Palladino et al., 2016; Sandberg et al., 2011; Yang et al., 2013) and comparisons are not possible. Our study shows that mobile learning is effective, disregarding the age of the participant and their previous experience with online risks. Consequently, results of this study encourage the use of mobile learning among adolescents since its effectiveness has been verified regardless of their individual characteristics. 
RISKS OF INTERACTIVE COMMUNICATION IN ADOLESCENTS.

DIGITAL LITERACY DIAGNOSIS AND INTERVENTION

\subsection{Critical Reflections and Limitations}

As every study, the present doctoral thesis suffers from several limitations that should be outlined for improvement in future studies. Thus, even though this research provides new insight into the study of digital literacy in adolescents and its outcomes, it also has some limitations that need to be addressed in future research.

First, and regarding the development and validation of the Digital Literacy Scale, the model fits of the two confirmatory factor analyses were just short of the recommended criteria. Considering that two of the digital skill factors have a questionable reliability, this may have influenced subsequent analyses. Accordingly, the internal consistency of the digital skills, measured by Cronbach's alpha, showed a low value in the communication skill factor $(\alpha=.46)$, and a questionable value in the informational skill factor $(\alpha=.63)$.

Consequently, future research may consider improvements of the measurements of the scale, especially for the communication and the informational skills. To this end, wording of the actual items should be checked again to look for enhancements. Moreover, in the case of the communication skill, since it is only measured through three items, it seems that additional items could be added for improvement of internal consistency.

Furthermore, and with reference to the sample, although we utilised a large and diverse sample of students, we only went to those schools in which principals and teachers allowed us to conduct the study. Therefore, we had to use a convenience sample instead of a random sample. It could be a fact that the participant schools were those in which principals and teachers are more concerned about digital literacy. Accordingly, participating students may have better technology access at school than do other students. Consequently, our convenience sample may not be representative of all adolescents in Spain. Moreover, the study was conducted only in one country. With the aim of testing the cross-cultural validity of the developed scale, future cross- 
national studies should test this scale in other Spanish speaking countries and with different samples.

Secondly, and with reference to the second study in the thesis, some limitations must also be recognised. First, the model fits of our model for hypothesis testing was just short of the recommended criteria. This means that the current data does not reflect the constructs and relationships in the population very well. This may be due to suboptimal measurements of the constructs in our study (i.e., digital literacy).

As with the previous study, the sample was taken only from Spanish secondary schools. As such, the generalisability of the findings to other countries, especially countries with lower levels of internet access, may be limited. However, it should be stressed that, at the same time, a strength of the present study is that adolescents were recruited through schools, which reduces the chance of selfselection bias for the adolescents. Moreover, the sample included adolescents from both rural and urban areas, which increases the generalisability of the results in terms of demographics in our sample.

Furthermore, a major limitation of the second study in the thesis is its crosssectional character. As a result, it is not possible to determine causal relationships and demonstrate that restrictive mediation reduces digital skills. It could be that adolescents who are digitally literate or who experience more online risks elicit more restrictive parental mediation out of concern for possible negative consequences. In fact, as has been argued previously (e.g., Appel, 2012), the relationship between digital media use and digital skills is likely to be reciprocal. Therefore, future research should investigate these relationships longitudinally.

Finally, and regarding the third study in the thesis, although the results are promising, this study also has several limitations. First, participants were not randomly assigned to the experimental and control groups. As such, this was a quasi- 
RISKS OF INTERACTIVE COMMUNICATION IN ADOLESCENTS.

DIGITAL LITERACY DIAGNOSIS AND INTERVENTION

experiment and not an experiment. This lack of randomisation may raise concerns regarding the internal validity of the study. As we stated, teachers and principals in schools usually insist on keeping the class structure intact, and this makes lack of randomisation a difficult limitation to overcome.

Furthermore, the conditions of the experiment may have influenced the results. Students were sitting next to each other in their current classrooms and they were required to use the mobile application only during a certain period. However, adolescents usually use mobile apps in a different way. Therefore, results might be different if participants were asked to use the app in a less controlled setting (All, Plovie, Nuñez Castellar, \& Van Looy, 2017).

Another limitation of the study is the lack of long term follow-up to assess whether improvements are maintained for any length of time after the intervention. We only used an immediate post-test and did not measure longer term effects of the mobile application.

Finally, narrative transportation, as a predictor variable, had no significant effect on the impact of the app. Moreover, it was the potential predictor variable with the lowest predictive level and only a small percentage of the students were mentally involved in the narrative while watching it. This raises concerns about the quality of the narrative. It would have been a good idea to have reached out to professional storytellers to create a quality narrative into which participants could have been transported (Murphy et al., 2013).

\subsection{Suggestions for Further Studies}

Considering the results and the limitations of the three studies in the doctoral thesis, some recommendations for future research will be outlined below.

First, as we mentioned previously, there is some room for improvement in the Digital Literacy Scale, in particular as regards the communication and informational

$$
\sim 232 \sim
$$


skills. Future studies aiming to improve the instrument should consider re-examining the formulation of the current items to look for enhancements and items to add to the factors with the lowest values of internal consistency. Moreover, future improvement of the scale could also include cross-cultural validation by testing the scale with samples from other Spanish speaking countries.

Furthermore, results from the second study showed that active parental mediation has no significant indirect relationship with online risks and opportunities through digital skills. Therefore, future research should further investigate whether parents indeed currently lack the knowledge to teach their children digital skills. If this is the case, we need to focus more on improving parents' digital skills and providing them tools for parenting in a digital age. Moreover, the fact that active mediation by parents is not related to adolescents' digital skills also suggests that adolescents adopt their digital literacy skills from sources other than their parents and build their digital skills independently, which subsequently forms their online experiences. For instance, children's digital literacy skills have previously been associated with their engagement in leisure activities with digital media (Appel, 2012). Future studies should investigate how adolescents adopt digital skills exactly, and which type of adolescents may be more or less able to do so. In that way, we can try to assist those adolescents that may not be able to independently become digitally literate.

Moreover, as one of the major limitations of the second study was its crosssectional character, it is highly advisable that further studies investigate relationships between parental mediation, digital skills, online opportunities and online risks longitudinally. This approach will help to establish causal relationships between these variables. Additionally, further research is recommended to test the developed theoretical model in other countries, since the generalisability of our findings may be limited. 
RISKS OF INTERACTIVE COMMUNICATION IN ADOLESCENTS.

DIGITAL LITERACY DIAGNOSIS AND INTERVENTION

As our intervention aimed to develop coping strategies for facing online risks, more research is needed to establish whether these strategies are effective in reducing harm associated with online risks. Future studies should also investigate if coping strategies for facing online risks are more effective for some adolescents than for others. Finally, as the use of the mobile application has been shown to be effective for developing personal security skill in adolescents, further studies could employ similar interventions for developing the other digital skills in this population.

\subsection{General Conclusions}

The present thesis dissertation has several original contributions. First, we have validated the Digital Literacy Scale. Despite some room for improvement in the measurement, we argue that, even in its current state, this is a valid and reliable instrument for measuring digital skills in adolescents and, as such, fills a gap in the field of digital literacy research. Second, to our knowledge this is the first study to examine how digital skills mediate the relationship between parental mediation and online risks and online opportunities. Our study builds a theoretical model explaining the mediation role of adolescents' digital skills on the relationship between parental mediation and online risks and opportunities. Thus, our research helps us understand how digital skills have a mediating role between (restrictive) parental behaviours and adolescents' online experiences that previous studies have not addressed. Third, this study shows that narrative persuasion and mobile learning can be combined successfully for promoting online safety and developing digital literacy in young people, and that mobile learning can be effective regardless of adolescents' individual characteristics.

As for every study, the present doctoral thesis suffers from several limitations that should be considered in future studies. Therefore, future research should look for improvement of the scale; should investigate relationships between parental

$$
\sim 234 \sim
$$


mediation, digital skills, online opportunities and online risks longitudinally; and should test the developed theoretical model in other countries.

Despite these limitations, we consider that this dissertation sheds light on the research on digital literacy in adolescents by developing a useful tool for measuring this construct and by highlighting its importance for an effective use of information and communication technology.

\subsection{Conclusiones Generales}

La presente tesis doctoral proporciona varias contribuciones originales. En primer lugar, a través del primer estudio empírico hemos validado la Escala de Alfabetización Digital. A pesar de existir margen de mejora en dicha herramienta metodológica, consideramos que en su estado actual es una herramienta válida y fiable para medir competencias digitales en adolescentes y, de esta forma, llena un vacío en la investigación en alfabetización digital. En segundo lugar, según nuestro conocimiento, este es el primer estudio que examina como las competencias digitales median en la relación entre mediación parental y riesgos y oportunidades online. De esta forma, nuestra investigación construye un modelo teórico que explica el rol de mediador de las competencias digitales de los adolescentes en la relación entre mediación parental y riesgos y oportunidades. Así, nuestra investigación ayuda a explicar cómo las competencias digitales tienen un rol mediador entre las iniciativas de mediación (restrictiva) y las experiencias online de los adolescentes que ningún estudio previo había analizado. En tercer lugar, esta investigación demuestra que la persuasión narrativa y el aprendizaje móvil pueden combinarse de forma exitosa para promover la seguridad online y desarrollar la alfabetización digital en la población adolescente; y que el aprendizaje móvil puede ser efectivo independientemente de las características individuales de los adolescentes.

Como en cualquier investigación, la presente tesis doctoral sufre de algunas limitaciones que deberán ser tenidas en cuentas en investigaciones futuras. Así, los 
RISKS OF INTERACTIVE COMMUNICATION IN ADOLESCENTS.

DIGITAL LITERACY DIAGNOSIS AND INTERVENTION

próximos estudios deberían tratar de mejorar la escala; deberían investigar la relación entre mediación parental, competencias digitales, oportunidades online y riesgos online de forma longitudinal; y deberían testar el modelo teórico desarrollado en otros países o contextos culturales.

A pesar de estas limitaciones, consideramos que esta tesis arroja luz en la investigación sobre alfabetización digital en adolescentes al desarrollar una herramienta para medir este constructo y al destacar su importancia para poder llevar a cabo un uso efectivo de las tecnologías de la información y la comunicación. 


\section{REFERENCES}

Adachi, P. J. C., \& Willoughby, T. (2013). More than just fun and games: the longitudinal relationships between strategic video games, self-reported problem solving skills, and academic grades. Journal of Youth and Adolescence, 42(7), 1041-1052. http://doi.org/10.1007/s10964-013-9913-9

Agatston, P. W., Kowalski, R., \& Limber, S. (2007). Students' perspectives on cyber bullying. Journal of Adolescent Health, 41, 59-60. http://doi.org/10.1016/j.jadohealth.2007.09.003

Ahmed, S., \& Parsons, D. (2013). Abductive science inquiry using mobile devices in the $\begin{array}{lllll}\text { classroom. } \quad C o m p u t e r s & \mathcal{E} & \text { Education, } & 63 & 62-72 .\end{array}$ http://doi.org/10.1016/j.compedu.2012.11.017

AIMC. (2012). Acceso a Internet de niños menores de 14 años en EGM. Retrieved from http://www.aimc.es/-EGM-Ninos-en-Internet-.html

AIMC. (2017). $2^{\text {a }}$ Ola EGM: aumenta el consumo de internet entre los menores de 14 años. Retrieved from http://www.aimc.es/armccont3nt/uploads/2017/o7/170705_egm_2017ola2.pdf

Ainley, J., Fraillon, J., Gebhardt, E., \& Schulz, W. (2012). National assessment program - ICT literacy years 6 \& 10 report 2011. Sidney: Acara.

Al-Emran, M., Mezhuyev, V., \& Kamaludin, A. (2018). Technology Acceptance Model in M-learning context: A systematic review. Computers \& Education, ${ }_{125}$ (August 2017), 389-412. http://doi.org/10.1016/J.COMPEDU.2018.06.0o8

Al-hawari, M. A., \& Mouakket, S. (2010). The influence of technology acceptance model (TAM) factors on students' e-satisfaction and e-retention within the context of UAE e-learning. Education, Business and Society: Contemporary Middle Eastern Issues, 3(4). http://doi.org/10.1108/17537981011089596

All, A., Plovie, B., Nuñez Castellar, E. P., \& Van Looy, J. (2017). Pre-test influences on the effectiveness of digital-game based learning: A case study of a fire safety

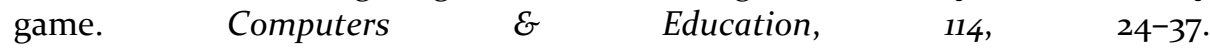
http://doi.org/10.1016/j.compedu.2017.05.018 
RISKS OF INTERACTIVE COMMUNICATION IN ADOLESCENTS.

DIGITAL LITERACY DIAGNOSIS AND INTERVENTION

Alsawaier, R. S. (2018). The effect of gamification on motivation and engagement. International Journal of Information and Learning Technology, 35(1), 56-79. http://doi.org/10.1108/IJILT-02-2017-0009

Álvarez-García, D., Dobarro, A., \& Núñez, J. C. (2015). Validez y fiabilidad del Cuestionario de cibervictimización en estudiantes de Secundaria. Aula Abierta, 43(1), 32-38. http://doi.org/10.1016/j.aula.2014.11.001

Álvarez, M., Torres, A., Rodríguez, E., Padilla, S., \& Rodrigo, M. J. J. (2013). Attitudes and parenting dimensions in parents' regulation of Internet use by primary and secondary school children. Computers \& Education, 67, 69-78. http://doi.org/10.1016/j.compedu.2013.03.005

Ananiadou, K., \& Claro, M. (2009). 21st century skills and competences for new millennium learners in OECD countries. OECD Education Working Papers, (41), 33. http://doi.org/10.1787/218525261154

Anderson, R. E. (2008). Implications of the information and knowledge society for education. In J. Voogt \& G. Knezek (Eds.), International Handbook of Information Technology in Primary and Secondary Education (Vol. 20, pp. 5-22). New York: Springer. http://doi.org/10.1007/978-0-387-73315-9

Ang, R. P. (2015). Adolescent cyberbullying: A review of characteristics, prevention and intervention strategies. Aggression and Violent Behavior, 25, 35-42. http://doi.org/10.1016/j.avb.2015.07.011

Appel, M. (2012). Are heavy users of computer games and social media more computer literate? Computers $\mathcal{E} \quad$ Education, $\quad 59(4), \quad 1339-1349$. http://doi.org/10.1016/j.compedu.2012.06.004

Appel, M., Gnambs, T., Richter, T., \& Green, M. C. (2015). The transportation scaleshort form (TS-SF). Media Psychology, 18(2), 243-266. http://doi.org/10.1080/15213269.2014.987400

Appel, M., \& Richter, T. (2007). Persuasive effects of fictional narratives increase over time. Media Psychology, 10, 113-134. http://doi.org/10.108/15213260701301194

Area, M., Gros, B., \& Marzal, M. A. (2008). Alfabetizaciones y tecnologías de la información y la comunicación. Madrid: Síntesis.

Area, M., \& Guarro, A. (2012). La alfabetización informacional y digital: fundamentos pedagógicos para la enseñanza y el aprendizaje competente. Revista Española de Documentación Científica, o(Monográfico), $\quad 46-74$. http://doi.org/10.3989/redc.2012.mono.977

Area Moreira, M. (2001). La alfabetización en la cultura y la tecnología digital. La tensión entre mercado y democracia. In M. Area (Ed.), Educar en la Sociedad de la Información (pp. 81-102). Bilbao: Desclée.

$$
\sim 238 \sim
$$


Area Moreira, M., Gutiérrez Martín, A., \& Vidal Fernández, F. (2011). Alfabetización digital y competencias informacionales. Fundación Telefónica. Barcelona: Ariel. Retrieved from https://ddv.ull.es/users/manarea/.../libro_ Alfabetizacion_digital.pdf $\% 5 \mathrm{Cn}$

Area Moreira, M., \& Pessoa, T. (2012). From solid to liquid: New literacies to the cultural changes of Web 2.0. Comunicar, 19(38), 13-20. http://doi.org/10.3916/C38-2011-02-01

Aricak, T., Siyahhan, S., Uzunhasanoglu, A., Saribeyoglu, S., Ciplak, S., Yilmaz, N., \& Memmedov, C. (2008). Cyberbullying among Turkish adolescents. CyberPsychology \& Behavior, 11(3), 253-261. http://doi.org/10.1089/cpb.2007.0016

Arnaiz, P., Cerezo, F., Giménez, A. M., \& Maquilón, J. J. (2016). Conductas de ciberadicción y experiencias de cyberbullying entre adolescentes. Anales de Psicología, 32(3), 761-769. http://doi.org/10.6018/analesps.32.3.217461

Arnone, M. P., Small, R. V., \& Reynolds, R. (2010). Supporting inquiry by identifying gaps in student confidence: Development of a measure of perceived competence. School Libraries Worldwide, 16(1), 47-60. Retrieved from http://surface.syr.edu/istpub/118/

Asbeek Brusse, E. D., Fransen, M. L., \& Smit, E. G. (2015). Educational storylines in entertainment television: Audience reactions toward persuasive strategies in medical dramas. Journal of Health Communication, 20(4), 396-405. http://doi.org/10.108o/10810730.2014.965365

Attali, Y., \& Arieli-Attali, M. (2015). Gamification in assessment: Do points affect test performance? Computers \& Education, 83, 57-63. http://doi.org/10.1016/j.compedu.2014.12.012

Aunola, K., Stattin, H., \& Nurmi, J. E. (2000). Parenting styles and adolescents' achievement strategies. Journal of Adolescence, 23(2), 205-222. http://doi.org/10.1006/jado.200o.0308

Austin, E. W., Chen, Y.-C., Pinkleton, B. E., \& Johnson, J. M. Q. (2006). Benefits and costs of Channel One in a middle school setting and the role of media-literacy training. PEDIATRICS, 117(3), e423-e433. http://doi.org/10.1542/peds.2005-0953

Austin, E. W., Pinkleton, B. E., \& Fujioka, Y. (200o). The role of interpretation processes and parental discussion in the media's effects on adolescents' use of alcohol. PEDIATRICS, 105(2), 343-349. http://doi.org/10.1542/peds.105.2.343

Ayala, G. X., Ibarra, L., Horton, L., Arredondo, E. M., Slymen, D. J., Engelberg, M., ... Elder, J. P. (2015). Evidence supporting a Promotora-delivered entertainment education intervention for improving mothers' dietary intake: The Entre Familia: Reflejos de Salud study. Journal of Health Communication, 2o(2), 165-176. http://doi.org/10.108o/10810730.2014.917747 
RISKS OF INTERACTIVE COMMUNICATION IN ADOLESCENTS. DIGITAL LITERACY DIAGNOSIS AND INTERVENTION

Ba, H., Tally, W., \& Tsikalas, K. (2002). Investigating children's emerging digital literacies. Journal of Technology, Learning and Assessment, 1(4).

Baams, L., Overbeek, G., Dubas, J. S., Doornwaard, S. M., Rommes, E., \& van Aken, M. A. G. (2015). Perceived realism moderates the relation between sexualized media consumption and permissive sexual attitudes in Dutch adolescents. Archives of Sexual Behavior, 44(3), 743-754. http://doi.org/10.1007/s10508-014-0443-7

Baard, P. P., Deci, E. L., \& Ryan, R. M. (2004). Intrinsic need satisfaction: A motivational basis of performance and weil-being in two work settings. Journal of Applied Social Psychology, 34(10), 2045-2068. http://doi.org/10.1111/j.15591816.2004.tbo2690.x

Bakke, E. (2010). A model and measure of mobile communication competence. Human Communication Research, 36(3), 348-371. http://doi.org/10.1111/j.14682958.2010.01379.X

Banerjee, S. C., \& Greene, K. (2007). Antismoking initiatives: Effects of analysis versus production media literacy interventions on smoking-related attitude, norm, and behavioral intention. Health Communication, 22(1), 37-48. http://doi.org/10.1080/10410230701310281

Bano, M., Zowghi, D., Kearney, M., Schuck, S., \& Aubusson, P. (2018). Mobile learning for science and mathematics school education: A systematic review of empirical evidence. Computers $\mathcal{E}$ Education, 121(February), $\quad 30-58$. http://doi.org/10.1016/j.compedu.2018.02.006

Baptista, G., \& Oliveira, T. (2017). Why so serious? Gamification impact in the acceptance of mobile banking services. Internet Research, 27(1), 118-139. http://doi.org/10.1108/IntR-10-2015-0295

Barbeite, F. G., \& Weiss, E. M. (2004). Computer self-efficacy and anxiety scales for an Internet sample: Testing measurement equivalence of existing measures and development of new scales. Computers in Human Behavior, 20(1), 1-15. http://doi.org/10.1016/So747-5632(03)ooo49-9

Barbovschi, M., Marinescu, V., Velicu, A., \& Laszlo, E. (2012). Meeting new contacts online. In S. Livingstone, L. Haddon, \& A. Görzig (Eds.), Children, Risk and Safety on the Internet. Research and policy challenges in comparative perspective (pp. 177-190). Bristol: The Policy Press.

Barnard-Wills, D. (2012). E-safety education: Young people, surveillance and responsibility. Criminology and Criminal Justice, 12(3), 239-255. http://doi.org/10.1177/1748895811432957

Barnard-Wills, D., \& Ashenden, D. (2015). Playing with privacy: Games for education and communication in the politics of online privacy. Political Studies, 63(1), 14216o. http://doi.org/10.1111/1467-9248.12049 
Baumgartner, S. E., Weeda, W. D., van der Heijden, L. L., \& Huizinga, M. (2014). The relationship between media multitasking and executive function in early adolescents. Journal of Early Adolescence, 34(8), 1120-1144. http://doi.org/10.1177/0272431614523133

Bawden, D. (2001). Information and digital literacies: a review of concepts. Journal of Documentation, 57(2), 218-259. http://doi.org/10.1108/EUMooooooooo7083

Bawden, D. (2002). Revisión de los conceptos de alfabetización informacional y alfabetización digital. Anales de Documentación, 5(1997), 361-408. http://doi.org/10.6018/2261

Bawden, D. (2008). Origins and concepts of digital literacy. In C. Lankshear \& M. Knobel (Eds.), Digital literacies: Concepts, policies and practices (pp. 17-32). New York: Peter Lang Publishing.

Baxter, L. A., Bylund, C. L., Imes, R., \& Routsong, T. (2009). Parent-child perceptions of parental behavioral control through rule-setting for risky health choices during adolescence. Journal of Family Communication, 9(4), 251-271. http://doi.org/10.1080/15267430903255920

Beentjes, J. W. J., Koolstra, C. M., Mareille, N., \& van der Voort, T. H. A. (2001). Children's use of different media: For how long and why? In S. Livingstone \& $\mathrm{M}$. Bovill (Eds.), Children and their changing media environment: A European comparative study (pp. 85-112). Mahwah, NJ: Lawrence Erlbaum Associates.

Bender, P. K., Plante, C., \& Gentile, D. A. (2017). The effects of violent media content on aggression. Current Opinion in Psychology, 19, 104-108. http://doi.org/10.1016/j.copsyc.2017.04.003

Bennett, S., Maton, K., \& Kervin, L. (2008). The 'digital natives' debate: a critical review of the evidence. British Journal of Educational Technology, 39(5), 775-786. http://doi.org/10.1111/j.1467-8535.2007.00793.X

Beran, T., \& Li, Q. (2007). The relationship between cyberbullying and school bullying. Journal of Student Wellbeing, 1(2), 16-33.

Berenguer, X. (2004). Una década de interactivos. Territorios de Diseño, 21, 30-35.

Bernabeu, N., Esteban, N., Gallego, L., \& Rosales, A. (2011). Alfabetización mediática y competencias básicas. Madrid: Mediascopio.

Berson, I. R., \& Berson, M. J. (2005). Challenging online behaviors of youth. Social Science Computer Review, 23(1), 29-38. http://doi.org/10.1177/o894439304271532

Beyens, I., Vandenbosch, L., \& Eggermont, S. (2015). Early adolescent boys' exposure to Internet pornography: Relationships to pubertal timing, sensation seeking, and academic performance. The Journal of Early Adolescence, 35(8), 1045-1068. http://doi.org/10.1177/0272431614548069 
RISKS OF INTERACTIVE COMMUNICATION IN ADOLESCENTS.

DIGITAL LITERACY DIAGNOSIS AND INTERVENTION

Bickham, D. S., \& Slaby, R. G. (2012). Effects of a media literacy program in the US on children's critical evaluation of unhealthy media messages about violence, smoking, and food. Journal of Children and Media, 6(2), 255-271. http://doi.org/10.108o/17482798.2012.662031

Billings, A. G., \& Moos, R. H. (1981). The role of coping responses and social resources in attenuating the stress of life events. Journal of Behavioral Medicine, 4(2), 139157. http://doi.org/10.1007/BFoo844267

Bindé, J., \& Matsuura, K. (2005). Towards knowledge societies. UNESCO world report (Vol. [1]). http://doi.org/ISBN 92-3-204000-X

Blakely, W. P. (1958). A study of seventh grade children's reading of comic books as related to certain other variables. The Journal of Genetic Psychology, 93(2), 291301.

Blumer, H. (1933). Movies and conduct. New York: The Macmillan Company.

Bonino, S., Ciairano, S., Rabaglietti, E., \& Cattelino, E. (2006). Use of pornography and self-reported engagement in sexual violence among adolescents. European Journal of Developmental Psychology, 3(3), 265-288. http://doi.org/10.1080/17405620600562359

Bovill, M., \& Livingstone, S. (2001). Bedroom culture and privatization of media use. In S. Livingstone \& M. Bovill (Eds.), Children and Their Changing Media Environment: A European Comparative Study (pp. 179-200). Lawrence Erlbaum Associates.

Boyaci, S., \& Atalay, N. (2016). A scale development for 21st century skills of primary school students: a validity and reliability study. International Journal of Instruction, 9(1), 133-148. http://doi.org/10.12973/iji.2016.9111a

Braddock, K., \& Dillard, J. P. (2016). Meta-analytic evidence for the persuasive effect of narratives on beliefs, attitudes, intentions, and behaviors. Communication Monographs, 83(4), 446-467. http://doi.org/10.108o/o3637751.2015.1128555

Brand, J. (1969). The effect of highly aggressive content in comic books on seventh grade children. Graduate Research in Urban Education E Related Disciplines, 5(1), 46-61.

Brandtweiner, R., Donat, E., \& Kerschbaum, J. (2010). How to become a sophisticated user: A two-dimensional approach to e-literacy. New Media E Society, 12(5), 813833. http://doi.org/10.1177/1461444809349577

Brewer, G., \& Kerslake, J. (2015). Cyberbullying, self-esteem, empathy and loneliness. Computers in Human Behavior, 48, 255-260. http://doi.org/10.1016/j.chb.2015.01.073

Brinkley, D. Y., Ackerman, R. A., Ehrenreich, S. E., \& Underwood, M. K. (2017). Sending 
and receiving text messages with sexual content: Relations with early sexual activity and borderline personality features in late adolescence. Computers in Human Behavior, 70, 119-130. http://doi.org/10.1016/j.chb.2016.12.082

Briz-Ponce, L., Juanes-Méndez, J. A., García-Peñalvo, F. J., \& Pereira, A. (2016). Effects of mobile learning in medical education: A counterfactual evaluation. Journal of Medical Systems, 40(6). http://doi.org/10.1007/s10916-016-0487-4

Brodzinsky, D. M., Elias, M. J., Steiger, C., Simon, J., Gill, M., \& Hitt, J. C. (1992). Coping scale for children and youth: Scale development and validation. Journal of Applied Developmental Psychology, 13(2), 195-214. http://doi.org/10.1016/o1933973(92)90029-H

Brown, B. B., \& Bakken, J. P. (2011). Parenting and peer relationships: Reinvigorating research on family-peer linkages in adolescence. Journal of Research on Adolescence, 21(1), 153-165. http://doi.org/10.1111/j.1532-7795.2010.00720.x

Brown, J. A. (2001). Media literacy and critical television viewing in education. In D. G. Singer \& J. L. Singer (Eds.), Handbook of children and the media (pp. 681-697). United States of America: Sage Publications.

Brown, J. D., \& Bobkowski, P. S. (2011). Older and newer media: Patterns of use and effects on adolescents' health and well-being. Journal of Research on Adolescence, 21(1), 95-113. http://doi.org/10.1111/j.1532-7795.2010.00717.x

Brown, J. D., \& L'Engle, K. L. (2009). X-Rated. Sexual attitudes and behaviors associated with U.S. early adolescents' exposure to sexually explicit media. Communication Research, 36(1), 129-151. http://doi.org/10.1177/0093650208326465

Brown, T. A. (2015). Confirmatory factor analysis for applied research (Second Edi). London: The Guilford Press.

Brown, W. J., \& Singhal, A. (1999). Entertainment-education media strategies for social change: Promises and problems. In D. P. Demers \& K. Viswanath (Eds.), Mass media, social control, and social change (pp. 263-28o). Ames, Iowa: Iowa State University Press.

Brusse, E. D. A., Fransen, M. L., \& Smit, E. G. (2017). Framing in entertainmenteducation: Effects on processes of narrative persuasion. Health Communication, 32(12), 1501-1509. http://doi.org/10.1080/10410236.2016.1234536

Bryant, J. A., Sanders-Jackson, A., \& Smallwood, A. M. K. (2006). IMing, text messaging, and adolescent social networks. Journal of Computer-Mediated Communication, 11(2), 577-592. http://doi.org/10.1111/j.1083-6101.2006.00028.x

Buckingham, D. (2008). What do young people need to know about digital media? In C. Lankshear \& M. Knobel (Eds.), Digital Literacies: Concepts, Policies and 
RISKS OF INTERACTIVE COMMUNICATION IN ADOLESCENTS.

DIGITAL LITERACY DIAGNOSIS AND INTERVENTION

Practices (pp. 73-88). New York: Peter Lang Publishing.

Buckley, P., \& Doyle, E. (2016). Gamification and student motivation. Interactive Learning Environments, 24(6), 1162-1175. http://doi.org/10.108o/10494820.2014.964263

Buijzen, M., Rozendaal, E., Moorman, M., \& Tanis, M. (2008). Parent versus child reports of parental advertising mediation: Exploring the meaning of agreement. Journal of Broadcasting \& Electronic Media, 52(4), 509-525. http://doi.org/10.1080/o8838150802437180

Buijzen, M., \& Valkenburg, P. M. (2005). Parental mediation of undesired advertising effects. Journal of Broadcasting \& Electronic Media, 49(2), 153-165. http://doi.org/10.1207/s15506878jobem4902

Bulger, M. E., Mayer, R. E., \& Metzger, M. J. (2014). Knowledge and processes that predict proficiency in digital literacy. Reading and Writing, 27(9), 1567-1583. http://doi.org/10.1007/s11145-014-9507-2

Bunz, U. (2004). The Computer-Email-Web (CEW) fluency scale-Development and validation. International Journal of Human-Computer Interaction, 17 (May 2001), 479-506. http://doi.org/10.1207/s1532759oijhc1704_3

Bunz, U., Curry, C., \& Voon, W. (2007). Perceived versus actual computer-email-web fluency. Computers in Human Behavior, 23(5), 2321-2344. http://doi.org/10.1016/j.chb.2006.03.008

Burgess, S. R., \& Murray, A. B. (2014). Use of traditional and smartphone app flashcards in an introductory psychology class. Journal of Instructional Pedagogies, 13, 1-7. Retrieved from http://search.proquest.com/docview/1515636593?accountid=41248

Bushman, B. J., \& Huesmann, L. R. (2006). Short-term and long-term effects of violent media on aggression in children and adults. Archives of Pediatrics $\mathcal{E}$ Adolescent Medicine, 160(4), 348. http://doi.org/10.1001/archpedi.16o.4.348

Cabello-Hutt, T., Cabello, P., \& Claro, M. (2017). Online opportunities and risks for children and adolescents: The role of digital skills, age, gender and parental mediation in Brazil. New Media \& Society, 1-21. http://doi.org/10.1177/1461444817724168

Cabero Almenara, J., Marín Díaz, V., \& Llorente Cejudo, M. D. C. (2012). Desarrollar la competencia digital. Educación mediática a lo largo de toda la vida. Sevilla: MAD.

Çakıroğlu, Ü., Başıbüyük, B., Güler, M., Atabay, M., \& Yılmaz Memiş, B. (2017). Gamifying an ICT course: Influences on engagement and academic performance. Computers in Human Behavior, 69, 98-107. http://doi.org/10.1016/j.chb.2016.12.018 
Calvete, E., Orue, I., Estévez, A., Villardón, L., \& Padilla, P. (2010). Cyberbullying in adolescents: Modalities and aggressors' profile. Computers in Human Behavior, 26(5), 1128-1135. http://doi.org/10.1016/j.chb.2010.03.017

Çankaya, S., \& Odabaşi, H. F. (2009). Parental controls on children's computer and internet use. Procedia - Social and Behavioral Sciences, 1(1), 1105-1109. http://doi.org/10.1016/j.sbspro.2009.01.199

Carvalho, J., Francisco, R., \& Relvas, A. P. (2015). Family functioning and information and communication technologies: How do they relate? A literature review. Computers in Human Behavior, 45, 99-108. http://doi.org/10.1016/j.chb.2014.11.037

Carver, C. S., Scheier, M. F., \& Weintraub, J. K. (1989). Assessing coping strategies: A theoretically based approach. Journal of Personality and Social Psychology, 56(2), 267-283. http://doi.org/10.1037/oo22-3514.56.2.267

Castells, M. (2007). Communication, power and counter-power in the network society. International Journal of Communication, 1, 238-266. http://doi.org/691180903390885

Catalina García, B., López de Ayala López, M. C., \& García Jiménez, A. (2014). Los riesgos de los adolescentes en Internet: Los menores como actores y víctimas de los peligros de Internet. Revista Latina de Comunicacion Social, 69, 462-485. http://doi.org/10.4185/RLCS-2014-1020

Causey, D. L., \& Dubow, E. F. (1992). Development of a self-report coping measure for elementary school children. Journal of Clinical Child Psychology, 21(1), 47-59. http://doi.org/10.1207/s15374424jccp2101_8

Cernikova, M., Dedkova, L., \& Smahel, D. (2018). Youth interaction with online strangers: experiences and reactions to unknown people on the Internet. Information, Communication $\mathcal{E}$ Society, 21(1), 94-110. http://doi.org/10.108o/1369118X.2016.1261169

Chalfen, R. (2009). 'It's only a picture': sexting, 'smutty' snapshots and felony charges '. Visual Studies, 24(3), 258-268. http://doi.org/10.1080/14725860903309203

Chang, C. Y., Lai, C. L., \& Hwang, G.-J. (2018). Trends and research issues of mobile learning studies in nursing education: A review of academic publications from 1971 to 2016. Computers \& Education, 116, 28-48. http://doi.org/10.1016/j.compedu.2017.09.001

Chang, K. E., Sung, Y. T., \& Lin, S. F. (2006). Computer-assisted learning for mathematical problem solving. Computers \& Education, 46(2), 140-151. http://doi.org/10.1016/j.compedu.2004.08.002

Chauhan, S. (2017). A meta-analysis of the impact of technology on learning 
RISKS OF INTERACTIVE COMMUNICATION IN ADOLESCENTS.

DIGITAL LITERACY DIAGNOSIS AND INTERVENTION

effectiveness of elementary students. Computers \& Education, 105, 14-30. http://doi.org/10.1016/j.compedu.2016.11.005

Chaux, E., Velásquez, A. M., Schultze-Krumbholz, A., \& Scheithauer, H. (2016). Effects of the cyberbullying prevention program media heroes (Medienhelden) on traditional bullying. Aggressive Behavior, 42(2), 157-165. http://doi.org/10.1002/ab.21637

Chee, K. N., Yahaya, N., Ibrahim, N. H., \& Hasan, M. N. (2017). Review of mobile learning trends 2010-2015: A meta-analysis. Educational Technology \& Society, 20(2), 113-126.

Chen, C. M., Tan, C. C., \& Lo, B. J. (2016). Facilitating English-language learners' oral reading fluency with digital pen technology. Interactive Learning Environments, 24(1), 96-118. http://doi.org/10.1080/10494820.2013.817442

Chen, F. F., Sousa, K. H., \& West, S. G. (2005). Teacher's corner: testing measurement invariance of second-order factor models. Structural Equation Modeling: A Multidisciplinary Journal, 12(3), 471-492. http://doi.org/10.1207/s15328007sem1203_7

Chen, M., Bell, R. A., \& Taylor, L. D. (2016). Narrator point of view and persuasion in health narratives: The role of protagonist-reader similarity, identification, and self-referencing. Journal of Health Communication, 21(8), 908-918. http://doi.org/10.1080/10810730.2016.1177147

Chen, M., Bell, R. A., \& Taylor, L. D. (2017). Persuasive effects of point of view, protagonist competence, and similarity in a health narrative about type 2 diabetes. Journal of Health Communication, 22(8), 702-712. http://doi.org/10.1080/10810730.2017.1341568

Chen, V. H. H., \& Chng, G. S. (2016). Active and restrictive parental mediation over time: Effects on youths' self-regulatory competencies and impulsivity. $\begin{array}{llll}\text { Computers } & \mathcal{E} & \text { Education, 206-212. }\end{array}$ http://doi.org/10.1016/j.compedu.2016.03.012

Cheung, A. C. K., \& Slavin, R. E. (2013). The effectiveness of educational technology applications for enhancing mathematics achievement in K-12 classrooms: A meta-analysis. Educational Research Review, 9, 88-113. http://doi.org/10.1016/j.edurev.2013.01.001

Chibnall, S., Wallace, M., Leicht, C., \& Lunghofer, L. (2006). I-safe evaluation. Virginia. Retrieved from https://www.ncjrs.gov/pdffilesı/nij/grants/213715.pdf

Childnet International. (2016). Be safe and smart online. Lesson plans for secondary school teachers. National Deaf Children's Society.

Chisholm, J. F. (2006). Cyberspace violence against girls and adolescent females.

$$
\sim 246 \sim
$$


Annals of the New York Academy of Sciences, 1087, 74-89. http://doi.org/10.1196/annals.1385.022

Christy, K. R. (2017). I, You, or He: Examining the impact of point of view on narrative persuasion. Media Psychology, oo(oo), 1-19. http://doi.org/10.108o/15213269.2017.1400443

Clark, L. S. (2011). Parental mediation theory for the digital age. Communication Theory, 21(4), 323-343. http://doi.org/10.1111/j.1468-2885.2011.01391.X

Claro, M., Preiss, D. D., San Martín, E., Jara, I., Hinostroza, J. E., Valenzuela, S., ... Nussbaum, M. (2012). Assessment of 21st century ICT skills in Chile: Test design and results from high school level students. Computers $\mathcal{E}$ Education, 59(3), 10421053. http://doi.org/10.1016/j.compedu.2012.04.004

Cohen-Almagor, R. (2018). Social responsibility on the Internet: Addressing the challenge of cyberbullying. Aggression and Violent Behavior, 39(January), 42-52. http://doi.org/10.1016/j.avb.2018.01.001

Cohen, J. (2001). Defining identification: A theoretical look at the identification of audiences with media characters. Mass Communication $\mathcal{E}$ Society, 4(3), 245-264. http://doi.org/10.1207/S15327825MCSo403_01

Cohen, J., \& Tal-Or, N. (2017). Antecedents of identification: Character, text, and audiences. In F. Hakemulder, M. M. Kuijpers, E. S. Tan, K. Bálint, \& M. M. Doicaru (Eds.), Narrative Absorption (pp. 133-156). Philadelphia: John Benjamins.

Cohen, J., Weimann-Saks, D., \& Mazor-Tregerman, M. (2017). Does character similarity increase identification and persuasion? Media Psychology, oo(oo), 123. http://doi.org/10.108o/15213269.2017.1302344

Colás, P., González, T., \& de Pablos, J. (2013). Juventud y redes sociales: Motivaciones y usos preferentes. Comunicar, $\quad X X(40), \quad 15^{-23}$. http://doi.org/http://dx.doi.org/10.3916/C40-2013-02-01

Conde, M. Á., García-Peñalvo, F. J., Alier, M., \& Piguillem, J. (2013). The implementation, deployment and evaluation of a mobile personal learning environment. Journal of Universal Computer Science, 19(7), 854-872. http://doi.org/10.3217/jucs-019-07-0854

Cooner, T. S., Knowles, A., \& Stout, B. (2016). Creating a mobile app to teach ethical social media practices. Social Work Education, 35(3), 245-259. http://doi.org/10.1080/02615479.2015.1042361

Cooper, J., \& Mackie, D. (1986). Video games and aggression in children. Journal of Applied Social Psychology, 16(8), 726-744.

Cooper, N., Lockyer, L., \& Brown, I. (2013). Developing multiliteracies in a technology- 
RISKS OF INTERACTIVE COMMUNICATION IN ADOLESCENTS.

DIGITAL LITERACY DIAGNOSIS AND INTERVENTION

mediated environment. Educational Media International, 50(2), 93-107. http://doi.org/10.1080/09523987.2013.795350

Cooperstein, S. E., \& Kocevar-Weidinger, E. (2004). Beyond active learning: a constructivist approach to learning. Reference Services Review, 32(2), 141-148. http://doi.org/10.1108/o0907320410537658

Crawford, M. R., Holder, M. D., \& O'Connor, B. P. (2016). Using mobile technology to engage children with nature. Environment and Behavior, o01391651667387. http://doi.org/10.1177/oo13916516673870

Crimmins, D. M., \& Seigfried-Spellar, K. C. (2014). Peer attachment, sexual experiences, and risky online behaviors as predictors of sexting behaviors among undergraduate students. Computers in Human Behavior, 32, 268-275. http://doi.org/10.1016/j.chb.2013.12.012

Crompton, H. (2013). A historical overview of m-learning: Toward learner-centred education. In Z. L. Berge \& L. Y. Muilenburg (Eds.), Handbook of mobile learning (pp. 80-107).

Cross, D., Shaw, T., Hadwen, K., Cardoso, P., Slee, P., Roberts, C., ... Barnes, A. (2016). Longitudinal impact of the Cyber Friendly Schools program on adolescents' cyberbullying behavior. Aggressive Behavior, 42(2), 166-180. http://doi.org/10.1002/ab.216o9

d'Haenens, L., Vandoninck, S., \& Donoso, V. (2013). How to cope and build online resilience? Retrieved from http://www2.lse.ac.uk/media@lse/research/EUKidsOnline/Home.aspx

Daneels, R., \& Vanwynsberghe, H. (2017). Mediating social media use: Connecting parents' mediation strategies and social media literacy. Cyberpsychology: Journal of Psychosocial Research on Cyberspace, 11 (3 Special Issue). http://doi.org/10.5817/CP2017-3-5

Daud, A., Omar, S. Z., Hassan, M. S., Bolong, J., \& Teimouri, M. (2014). Parental mediation of children's positive use of the internet. Life Science Journal, ${ }_{11}(8)$, 360-369.

Davidson, J., Martellozzo, E., \& Lorenz, M. (2009). Evaluation of CEOP ThinkUKnow internet safety programme and exploration of young people's internet safety knowledge. Kingston University London. Retrieved from http://eprints.mdx.ac.uk/5976/

Davis, F. D. (1989). Perceived usefulness, perceived ease of use, and user acceptance of information technology. MIS Quarterly, 13(3), 319-340.

de Graaf, A. (2014). The effectiveness of adaptation of the protagonist in narrative impact: Similarity influences health beliefs through self-referencing. Human

$$
\sim 248 \sim
$$


Communication Research, 40(1), 73-90. http://doi.org/10.1111/hcre.12015

de Graaf, A., Hoeken, H., Sanders, J., \& Beentjes, J. W. J. (2012). Identification as a mechanism of narrative persuasion. Communication Research, 39(6), 802-823. http://doi.org/10.1177/o093650211408594

de Graaf, A., Sanders, J., \& Hoeken, H. (2016). Characteristics of narrative interventions and health effects: a review of the content, form, and context of narratives in health-related narrative persuasion research. Review of Communication Research, 4, 88-131. http://doi.org/10.12840/issn.2255-4165.2016.04.01.011

de Graaf, A., \& van Leeuwen, L. (2017). The role of absorption processes in narrative health communication. In F. Hakemulder, M. M. Kuijpers, E. S. Tan, K. Bálint, \& M. M. Doicaru (Eds.), Narrative Absorption (pp. 271-292). Philadelphia: John Benjamins.

De Wit, K., Heerwegh, D., \& Verhoeven, J. C. (2014). Can openness to ICT and scientific research predict the ICT skills and ICT use of bachelor's students? Computers $\mathcal{E}$ Education, 78, 397-413. http://doi.org/10.1016/j.compedu.2014.07.003

Dehue, F., Bolman, C. A. W., \& Völlink, T. (2008). Cyberbullying: Youngsters' experiences and parental perception. CyberPsychology E Behavior, 11(2), 217-223. http://doi.org/10.1089/cpb.2007.0008

Del Rey, R., Estévez, M., \& Ojeda, M. (2018). El ciberacoso y su respuesta educativa. In Entre selfies y whatsapps. Oportunidades y riesgos para la infancia y la adolescencia conectada (pp. 125-140). Barcelona: Gedisa.

Delevi, R., \& Weisskirch, R. S. (2013). Personality factors as predictors of sexting. Computers in Human Behavior, 29(6), 2589-2594. http://doi.org/10.1016/j.chb.2013.06.003

Della Cioppa, V., O’Neil, A., \& Craig, W. (2015). Learning from traditional bullying interventions: A review of research on cyberbullying and best practice. Aggression and Violent Behavior, 23, 61-68. http://doi.org/10.1016/j.avb.2015.05.009

Desmet, A., Cleemput, K. Van, Poels, K., Vandebosch, H., Troyer, O. De, \& Hoecke, S. Van. (2017). The efficacy of the Friendly Attac serious digital game to promote prosocial bystander behavior in cyberbullying among young adolescents?: a cluster-randomized controlled trial. Computers in Human Behavior, 78, 336-347. http://doi.org/10.1016/j.chb.2017.10.011

Dettori, G. (2007). Narrative learning environments and mobile learning: a good relationship? In I. Arnedillo-Sánchez, M. Sharples, \& G. Vavoula (Eds.), Beyond Mobile Learning Workshop (pp. 8-11). Trinity College Dublin Press.

Diliberto-Macaluso, K., \& Hughes, A. (2016). The use of mobile apps to enhance 
RISKS OF INTERACTIVE COMMUNICATION IN ADOLESCENTS.

DIGITAL LITERACY DIAGNOSIS AND INTERVENTION

student learning in introduction to psychology. Teaching of Psychology, 43(1), 48-52. http://doi.org/10.1177/009862831562088o

Dincer, S. (2012). A study of the relationship between pupils and parents' computer literacy level and use. Procedia - Social and Behavioral Sciences, 46, 484-489. http://doi.org/10.1016/j.sbspro.2012.05.146

Domínguez, A., Saenz-De-Navarrete, J., De-Marcos, L., Fernández-Sanz, L., Pagés, C., \& Martínez-Herráiz, J. J. (2013). Gamifying learning experiences: Practical implications and outcomes. Computers $\mathcal{E}$ Education, 63, 380-392. http://doi.org/10.1016/j.compedu.2012.12.020

Doornwaard, S. M., van den Eijnden, R., Baams, L., Vanwesenbeeck, I., \& ter Bogt, T. (2016). Lower psychological well-being and excessive sexual interest predict symptoms of compulsive use of sexually explicit Internet material among adolescent boys. Journal of Youth and Adolescence, 45(1), 73-84. http://doi.org/10.1007/s10964-015-0326-9

Doornwaard, S. M., van den Eijnden, R., Overbeek, G., \& ter Bogt, T. (2015). Differential developmental profiles of adolescents using sexually explicit Internet material. Journal of Sex Research, 52(3), 269-281. http://doi.org/10.1080/00224499.2013.866195

Döring, N. (2014). Consensual sexting among adolescents: Risk prevention through abstinence education or safer sexting? Cyberpsychology: Journal of Psychosocial Research on Cyberspace, 8(1). http://doi.org/10.5817/CP2014-1-9

Dornbusch, S. M., Ritter, P. L., Leiderman, P. H., Roberts, D. F., \& Fraleigh, M. J. (1987). The relation of parenting style to adolescent school performance. Child Development, 58(5), 1244-1257. http://doi.org/10.2307/1130618

Dowdell, E. B. (2011). Risky Internet behaviors of middle-school students. CIN: Computers, Informatics, Nursing, 29(6), 352-359. http://doi.org/10.1097/NCN.obo13e3181fcbdbo

Dowdell, E. B., Burgess, A. W., \& Cavanaugh, D. J. (2009). Clustering of Internet risk behaviors in a middle school student population. Journal of School Health, 79(11), 547-553. Retrieved from http://ovidsp.ovid.com/ovidweb.cgi?T=JS\&PAGE=reference\&D=emed12\&NEW $\mathrm{S}=\mathrm{N} \& \mathrm{AN}=355428172$

Downs, J. S., Murray, P. J., Bruine De Bruin, W., Penrose, J., Palmgren, C., \& Fischhoff, B. (2004). Interactive video behavioral intervention to reduce adolescent females' STD risk: A randomized controlled trial. Social Science and Medicine, 59(8), 1561-1572. http://doi.org/10.1016/j.socscimed.2004.01.032

Doyle, C. S. (1994). Information literacy in an information society: A concept for the information age. Syracuse, NY: ERIC Clearinghouse,. 
Duerager, A., \& Livingstone, S. (2012). How can parents support children's internet safety? LSE, London: EU Kids Online. Retrieved from http://eprints.lse.ac.uk/42872/

Duran, R. L., Yousman, B., Walsh, K. M., \& Longshore, M. A. (2008). Holistic media education: An assessment of the effectiveness of a college course in media literacy. Communication Quarterly, 56(1), 49-68. http://doi.org/10.108o/01463370701839198

Durndell, A., \& Haag, Z. (2002). Computer self efficacy, computer anxiety, attitudes towards the Internet and reported experience with the Internet, by gender, in an East European sample. Computers in Human Behavior, 18(5), 521-535. http://doi.org/10.1016/So747-5632(o2)oooo6-7

Ebata, A., \& Moos, R. (1991). Coping and adaptation in distressed and healthy adolescents. Journal of Applied Developmental Psychology, 12, 33-54.

El-Hussein, M. O. M., \& Cronje, J. C. (2010). Defining mobile learning in the higher education landscape. Educational Technology \& Society, 13, 12-21. http://doi.org/10.4018/978-1-4666-6343-5

Elkartea Suspergintza. (2015). EgOn Line: Guía pedagógica para trabajar la educación en las nuevas tecnologías. (Servicio Central de Publicaciones del Gobierno Vasco, Ed.). San Sebastián.

Elson, M., Breuer, J., Ivory, J. D., \& Quandt, T. (2014). More than stories with buttons: Narrative, mechanics, and context as determinants of player experience in digital games. Journal of Communication, 64(3), 521-542. http://doi.org/10.1111/jcom.12096

Elwood, S., Changchit, C., \& Cutshall, R. (2006). Investigating students' perceptions on laptop initiative in higher education. Campus-Wide Information Systems, 23(5), 336-349. http://doi.org/10.1108/10650740610714099

Eshet-Alkalai, Y. (2004). Digital literacy: A conceptual framework for survival skills in the digital era. Journal of Educational Multimedia and Hypermedia, 13(1), 93-106. Retrieved from http://www.editlib.org/p/4793

Eshet-Alkalai, Y., \& Amichai-Hamburger, Y. (2004). Experiments in digital literacy. $\begin{array}{lllll}\text { Cyberpsychology } & \mathcal{E} & \text { Behavior, } & 7(4), & 421-429 .\end{array}$ http://doi.org/10.1089/cpb.2004.7.421

Eshet-Alkalai, Y., \& Chajut, E. (2009). Changes over time in digital literacy. Cyberpsychology, 12(6), 713-715. http://doi.org/10.1089/cpb.2008.0264

ETS. (2002). Digital Transformation: A framework for ICT literacy. Retrieved from http://www.ets.org/Media/Tests/Information_and_Communication_Technolo gy_Literacy/ictreport.pdf 
RISKS OF INTERACTIVE COMMUNICATION IN ADOLESCENTS.

DIGITAL LITERACY DIAGNOSIS AND INTERVENTION

Eurostat. (2016). Internet access and use statistics - households and individuals. Bruselas: Eurostat.

Fan, M., Liyue, Y., \& Bowler, L. (2016). Feelbook??: A social media app for teens designed to foster positive online behavior and prevent cyberbullying. $\mathrm{CHI}$ Extended Abstracts on Human Factors in Computing Systems, 1187-1192. http://doi.org/10.1145/2851581.2892398

Faul, F., Erdfelder, E., Lang, A.-G., \& Buchner, A. (2007). G*Power: A flexible statistical power analysis program for the social, behavioral, and biomedical sciences. Behavior Research Methods, 39(2), 175-191. http://doi.org/10.3758/BFo3193146

Favotto, L., Michaelson, V., \& Davison, C. (2017). Perceptions of the influence of computer-mediated communication on the health and well-being of early adolescents. International Journal of Qualitative Studies on Health and WellBeing, 12(1). http://doi.org/10.108o/17482631.2017.1335575

Ferguson, C. J., \& Kilburn, J. (2009). The public health risks of media violence: A metaanalytic review. Journal of Pediatrics, 154(5), 759-763. http://doi.org/10.1016/j.jpeds.2008.11.033

Fernández-Montalvo, J., Peñalva, A., \& Irazabal, I. (2015). Hábitos de uso y conductas de riesgo en Internet en la preadolescencia. Comunicar, 22(44), 113-121. http://doi.org/10.3916/C44-2015-12

Fernández-Montalvo, J., Peñalva, A., Irazabal, I., \& López-Goñi, J. J. (2017). Effectiveness of a digital literacy programme for primary education students. Culture and Education, 29(1), 1-30. http://doi.org/10.1080/11356405.2016.1269501

Fernández Pérez, A. (2016). La protección de los derechos fundamentales de los menores en Internet desde la perspectiva europea. Ius et Praxis, 22(1), 377-418. http://doi.org/10.4067/So718-00122016000100011

Ferrari, A. (2012). Digital competence in practice: An analysis of frameworks. Joint Research Centre. Luxembourg.

Ferrari, A. (2013). DIGCOMP: A Framework for developing and understanding digital competence in Europe. Luxembourg: Joint Research Centre of the European Commission. http://doi.org/10.2788/52966

Ferrari, A., Punie, Y., \& Redecker, C. (2012). Understanding digital competence in the 21st century: An analysis of current frameworks. 21st Century Learning for 21st Century Skills, 79-92. http://doi.org/10.2791/82116

Ferrés, J., \& Piscitelli, A. (2012). Media competence. Articulated proposal of dimensions and indicators. Comunicar, 19(38), 75-82. http://doi.org/10.3916/C38-2012-02-08

Festl, R., \& Quandt, T. (2016). The role of online communication in long-term 
cyberbullying involvement among girls and boys. Journal of Youth and Adolescence, 45(9), 1931-1945. http://doi.org/10.1007/s10964-016-0552-9

Field, A. P. (2013). Discovering statistics using IBM SPSS Statistics (4th Editio). London: Sage Publications.

Fikkers, K. M., Piotrowski, J. T., Lugtig, P., \& Valkenburg, P. M. (2016). The role of perceived peer norms in the relationship between media violence exposure and adolescents' aggression. Media Psychology, 19(1), 4-26. http://doi.org/10.108o/15213269.2015.103796o

Fingar, K. R., \& Jolls, T. (2014). Evaluation of a school-based violence prevention media literacy curriculum. Injury Prevention, 20(3), 183-190. http://doi.org/10.1136/injuryprev-2013-040815

Fitzgerald, K. S., \& Green, M. C. (2017). Narrative persuasion: Effects of transporting stories on attitudes, beliefs, and behaviors. In F. Hakemulder, M. M. Kuijpers, E. S. Tan, K. Bálint, \& M. M. Doicaru (Eds.), Narrative Absorption (pp. 49-68). Philadelphia: John Benjamins.

Fleming, M. J., Greentree, S., Cocotti-Muller, D., Elias, K. A., \& Morrison, S. (2006). Safety in cyberspace adolescents' safety and exposure online. Youth $\mathcal{E}$ Society, 38(2), 135-154. http://doi.org/10.1177/o044118Xo6287858

Flood, M. (2009). The harms of pornography exposure among children and young people. Child Abuse Review, 18(6), 384-400. http://doi.org/10.1002/car.1092

Folkman, S., \& Lazarus, R. S. (1988). The relationship between coping and emotion: implications for theory and research. Social Science \& Medicine, 26(3), 309-317. http://doi.org/10.1016/0277-9536(88)90395-4

Forster, M., Allem, J.-P., Mendez, N., Qazi, Y., \& Unger, J. B. (2016). Evaluation of a telenovela designed to improve knowledge and behavioral intentions among Hispanic patients with end-stage renal disease in Southern California. Ethnicity $\mathcal{E}$ Health, 21(1), 58-70. http://doi.org/10.1080/13557858.2015.1007119

Fosnot, C., \& Stewart, R. (2005). Constructivism: A psychological theory of learning. In C. Fosnot (Ed.), Constructivism, Theory, Perspectives and Practice (Second Edi, pp. 8-38). Teachers College. Retrieved from http://faculty.arts.ubc.ca/emeyers/LIBR535/readings/Fosnot\&Perry_2005.pdf

Fraillon, J., Ainley, J., Schulz, W., Friedman, T., \& Gebhardt, E. (2014). Preparing for life in a digital age: The IEA international computer and information literacy study international report. Australia: Springer International Publishing. Retrieved from http://research.acer.edu.au/cgi/viewcontent.cgi?article=1009\&context=ict_liter acy 
RISKS OF INTERACTIVE COMMUNICATION IN ADOLESCENTS. DIGITAL LITERACY DIAGNOSIS AND INTERVENTION

Frank, L. B., Murphy, S. T., Chatterjee, J. S., Moran, M. B., \& Baezconde-Garbanati, L. (2015). Telling stories, saving lives: Creating narrative health messages. Health Communication, 30(2), 154-163. http://doi.org/10.108o/10410236.2014.974126

Fujioka, Y., \& Austin, E. W. (2003). The implications of vantage point in parental mediation of television and child's attitudes toward drinking alcohol. Journal of $\begin{array}{llll}\text { Broadcasting } \mathcal{E} \quad \text { Electronic Media, } & 47(3), & 418-434 .\end{array}$ http://doi.org/10.1207/s15506878jobem4703_6

Fundación Telefónica. (2017). Sociedad digital en España 2017. Ariel.

Gabelas, J. A. (2010). Escenarios virtuales, cultura juvenil y educomunicación 2.o. In R. Aparici (Ed.), Educomunicación: más allá del 2.0 (pp. 151-168). Barcelona: Gedisa.

Gámez-Guadix, M., Almendros, C., Calvete, E., \& De Santisteban, P. (2018). Persuasion strategies and sexual solicitations and interactions in online sexual grooming of adolescents: Modeling direct and indirect pathways. Journal of Adolescence, 63(October 2017), 11-18. http://doi.org/10.1016/j.adolescence.2017.12.002

Gámez-Guadix, M., de Santisteban, P., \& Resett, S. (2017). Sexting entre adolescentes españoles: Prevalencia y asociación con variables de personalidad. Psicothema, 29(1), 29-34. http://doi.org/10.7334/psicothema2016.222

Garaigordobil, M. (2011). Prevalencia y consecuencias del cyberbullying: Una revisión. International Journal of Psychology and Psychological Therapy, 11(2), 233-254.

García Jiménez, A., López de Ayala López, M. C., \& Gaona Pisonero, C. (2012). A vision of uses and gratifications applied to the study of Internet use by adolescents. Comunicación Y Sociedad, XXV(2), 231-254.

Garitaonandia, C., Fernández, E., \& Oleaga, J. A. (2005). Las tecnologías de la información y de la comunicación y su uso por los niños y adolescentes. Doxa Comunicación, (3), 45-64. Retrieved from http://www.doxacomunicacion.es/pdf/artculogaritaonandia_1.pdf

Garmendia, M., Garitaonandia, C., \& Casado, M. Á. (2012). The effectiveness of parental mediation. In S. Livingstone, L. Haddon, \& A. Görzig (Eds.), Children, Risk and Safety on the Internet. Research and policy challenges in comparative perspective (pp. 231-244). Bristol: The Policy Press.

Garmendia, M., Jiménez, E., Casado, M. Á., \& Mascheroni, G. (2016). Net Children Go Mobile: Riesgos y oportunidades en internet y el uso de dispositivos móviles entre menores españoles (2010-2015). Madrid: Red.es/Universidad del País Vasco/Euskal Herriko Unibertsitatea.

Garmendia, M., \& Karrera, I. (2018). Sexting: qué sabemos y qué nos queda por aprender. In E. Jiménez, M. Garmendia, \& M. Á. Casado (Eds.), Entre selfies y whatsapps. Oportunidades y riesgos para la infancia y la adolescencia conectada 
(pp. 141-156). Barcelona: Gedisa.

Gastelú, C. A. T., Kiss, G., \& Domínguez, A. L. (2015). Level of ICT competencies at the University. Procedia - Social and Behavioral Sciences, 174, 137-142. http://doi.org/10.1016/j.sbspro.2015.01.638

Gati, A., Tényi, T., Túry, F., \& Wildmann, M. (2002). Anorexia nervosa following sexual harassment on the internet: A case report. International Journal of Eating Disorders, 31(4), 474-477. http://doi.org/10.1002/eat.10029

Gilster, P. (1997). Digital literacy. New York: Wiley.

Giménez Gualdo, A. M., Hunter, S. C., Durkin, K., Arnaiz, P., \& Maquilón, J. J. (2015). The emotional impact of cyberbullying: Differences in perceptions and experiences as a function of role. Computers $\mathcal{E}$ Education, 82, 228-235. http://doi.org/10.1016/j.compedu.2014.11.013

Göksu, İ., \& Atici, B. (2013). Need for mobile learning: Technologies and opportunities. Procedia - Social and Behavioral Sciences, 103, 685-694. http://doi.org/10.1016/j.sbspro.2013.10.388

Golpe Ferreiro, S., Gómez Salgado, P., Kim Harris, S., Braña, T., \& Rial, A. (2017). Diferencias de sexo en el uso de Internet en adolescentes españoles. Behavioral Psychology, 25(1), 129-146.

González, N. (2012). Alfabetización para una cultura social, digital, mediática y en red. Revista Española de Documentación Científica, o(Monográfico), 17-45. http://doi.org/10.3989/redc.2012.mono.976

Görzig, A. (2012). Methodological framework: the EU Kids Online project. In S. Livingstone, L. Haddon, \& A. Görzig (Eds.), Children, Risk and Safety on the Internet. Research and policy challenges in comparative perspective (pp. 15-32). Bristol: The Policy Press.

Gradinger, P., Yanagida, T., Strohmeier, D., \& Spiel, C. (2016). Effectiveness and sustainability of the ViSC Social Competence Program to prevent cyberbullying and cyber-victimization: Class and individual level moderators. Aggressive Behavior, 42(2), 181-193. http://doi.org/10.1002/ab.21631

Green, M. C., \& Brock, T. C. (200o). The role of transportation in the persuasiveness of public narratives. Journal of Personality and Social Psychology, 79(5), 701-721. http://doi.org/10.1037/0022-3514.79.5·701

Green, M. C., \& Brock, T. C. (2002). In the mind's eye: Transportation-imagery model of narrative persuasion. In Narrative impact: Social and cognitive foundations. (pp. 315-341). Mahwah, NJ, US: Lawrence Erlbaum Associates Publishers.

Green, M. C., Brock, T. C., \& Kaufman, G. F. (2004). Understanding media enjoyment: The role of transportation into narrative worlds. Communication Theory, 14(4), 
RISKS OF INTERACTIVE COMMUNICATION IN ADOLESCENTS.

DIGITAL LITERACY DIAGNOSIS AND INTERVENTION

311-327. http://doi.org/10.1093/ct/14.4.311

Green, M. C., \& Jenkins, K. M. (2014). Interactive narratives: Processes and outcomes in user-directed stories. Journal of Communication, 64(3), 479-500. http://doi.org/10.1111/jcom.12093

Gui, M., \& Argentin, G. (2011). Digital skills of internet natives: Different forms of digital literacy in a random sample of northern Italian high school students. New

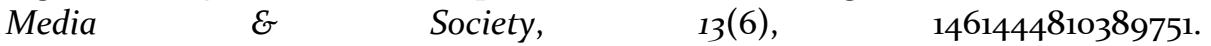
http://doi.org/10.1177/1461444810389751

Gutiérrez, A. (2003). Alfabetización digital: Algo más que ratones y teclas. Barcelona: Gedisa.

Haddon, L. (2013). Mobile media and children. Mobile Media \& Communication, 1(1), 89-95. http://doi.org/10.1177/2050157912459504

Haddon, L. (2018). Supervisión y control parental de los teléfonos inteligentes de los menores. In E. Jiménez, M. Garmendia, \& M. Á. Casado (Eds.), Entre selfies y whatsapps. Oportunidades y riesgos para la infancia y la adolescencia conectada (pp. 75-90). Barcelona: Gedisa.

Hakkarainen, K., Ilomäki, L., Lipponen, L., Muukkonen, H., Rahikainen, M., Tuominen, T., ... Lehtinen, E. (200o). Students' skills and practices of using ICT: results of a national assessment in Finland. Computers E Education, 34(2), 103117. http://doi.org/10.1016/So36o-1315(oo)oooo7-5

Halliwell, E., Easun, A., \& Harcourt, D. (2011). Body dissatisfaction: Can a short media literacy message reduce negative media exposure effects amongst adolescent girls? British Journal of Health Psychology, 16(2), 396-403. http://doi.org/10.1348/135910710X515714

Hamari, J., Koivisto, J., \& Sarsa, H. (2014). Does gamification work? - A literature review of empirical studies on gamification. Proceedings of the Annual Hawaii International Conference on System Sciences, 3025-3034. http://doi.org/10.1109/HICSS.2014.377

Hamdani, D. S. Al. (2013). Mobile learning: A good practice. Procedia - Social and Behavioral Sciences, 103, 665-674. http://doi.org/10.1016/j.sbspro.2013.10.386

Hand, S., \& Varan, D. (2009). Interactive stories and the audience. Computers in Entertainment, 7(3), 1. http://doi.org/10.1145/1594943.1594951

Hardy, S. A., Steelman, M. A., Coyne, S. M., \& Ridge, R. D. (2013). Adolescent religiousness as a protective factor against pornography use. Journal of Applied Developmental Psychology, 34(3), 131-139. http://doi.org/10.1016/j.appdev.2012.12.002

Hargittai, E. (2008). An update on survey measures of web-oriented digital literacy. 
Social Science Computer Review, 27(1), 130-137. http://doi.org/10.1177/0894439308318213

Hargittai, E., \& Hsieh, Y. P. (2012). Succinct survey measures of web-use skills. Social Science Computer Review, 30(1), 95-107. http://doi.org/10.1177/o894439310397146

Hayes, A. F. (2005). Statistical methods for communication science. Mahwah, New Jersey: Lawrence Erlbaum Associates.

Hayes, A. F. (2013). Introduction to mediation, moderation, and conditional process analysis?? a regression-based approach. New York: The Guilford Press.

Heinssen, R. K., Glass, C. R., \& Knight, L. a. (1987). Assessing computer anxiety: Development and validation of the Computer Anxiety Rating Scale. Computers in Human Behavior, 3(1), 49-59. http://doi.org/10.1016/0747-5632(87)90010-o

Heirman, W., Walrave, M., Vermeulen, A., Ponnet, K., Vandebosch, H., \& Hardies, K. (2015). Applying the theory of planned behavior to adolescents' acceptance of online friendship requests sent by strangers. Telematics and Informatics, 33(4), 1119-1129. http://doi.org/10.1016/j.tele.2016.01.002

Helsper, E. J., \& Eynon, R. (2013). Distinct skill pathways to digital engagement. European Journal of Communication, 28(6), 696-713. http://doi.org/10.1177/0267323113499113

Hermida, R. (2015). The problem of allowing correlated errors in structural equation modeling: Concerns and considerations. Computational Methods in Social Sciences, 3(1), 5-17. Retrieved from http://cmss.univnt.ro/wpcontent/uploads/vol/split/vol_III_issue_1/CMSS_vol_III_issue_1_art.oo1.pdf

Hernández-Ramos, J. P., Martínez-Abad, F., García-Peñalvo, F. J., Herrera García, M. E., \& Rodríguez-Conde, M. J. (2014). Teachers' attitude regarding the use of ICT. A factor reliability and validity study. Computers in Human Behavior, 31(1), 509516. http://doi.org/10.1016/j.chb.2013.04.039

Hether, H. J., Huang, G. C., Beck, V., Murphy, S. T., \& Valente, T. W. (2008). Entertainment-education in a media-saturated environment: Examining the impact of single and multiple exposures to breast cancer storylines on two popular medical dramas. Journal of Health Communication, 13(8), 808-823. http://doi.org/10.108o/10810730802487471

Hinduja, S., \& Patchin, J. W. (2010). Bullying, cyberbullying, and suicide. Archives of Suicide Research?]: Official Journal of the International Academy for Suicide Research, 14(3), 206-221. http://doi.org/10.1080/13811118.2010.494133

Hirsh-Pasek, K., Zosh, J. M., Golinkoff, R. M., Gray, J. H., Robb, M. B., \& Kaufman, J. (2015). Putting education in "educational" apps: Lessons from the science of learning. Psychological Science in the Public Interest, 16(1), 3-34. 
RISKS OF INTERACTIVE COMMUNICATION IN ADOLESCENTS.

DIGITAL LITERACY DIAGNOSIS AND INTERVENTION

http://doi.org/10.1177/1529100615569721

Hoeken, H., Kolthoff, M., \& Sanders, J. (2016). Story perspective and character similarity as drivers of identification and narrative persuasion. Human Communication Research, 42(2), 292-311. http://doi.org/10.1111/hcre.12076

Hootsuite. (2015). Digital, social \& mobile in 2015. We are social's compendium of global digital statistics.

Hootsuite. (2017). Digital in 2017 Global overview. A collection of Internet, social media, and mobile data from around the world.

Hootsuite. (2018). Digital in 2018. Essential insights into internet, social media, mobile and ecommerce use around the world.

Houck, C. D., Barker, D., Rizzo, C., Hancock, E., Norton, A., \& Brown, L. K. (2014). Sexting and sexual behavior in at-risk adolescents. Pediatrics, 133(2), 276-282. http://doi.org/10.1542/peds.2013-1157

Hswen, Y., Rubenzahl, L., \& Bickham, D. S. (2014). Feasibility of an online and mobile videogame curriculum for teaching children safe and healthy cellphone and Internet behaviors. Games for Health Journal, 3(4), 252-259. http://doi.org/10.1089/g4h.2013.0074

Huang, R. Y.-M., Lin, Y. T., \& Cheng, S. C. (2010). Effectiveness of a mobile plant learning system in a science curriculum in Taiwanese elementary education. $\begin{array}{lllll}\text { Computers } & \mathcal{E} & \text { Education, } & \text { 54(1), }\end{array}$ http://doi.org/10.1016/j.compedu.2009.07.0o6

Hudson, H. K., Fetro, J. V., \& Ogletree, R. (2014). Behavioral indicators and behaviors related to sexting among undergraduate students. American Journal of Health Education, 45(3), 183-195. http://doi.org/10.108o/19325037.2014.901113

Hunter, C. D. (200o). Internet filter effectiveness-testing over- and underinclusive blocking decisions of four popular web filters. Social Science Computer Review, 18(23519), 214-222.

Hust, S. J. T., Adams, P. M., Willoughby, J. F., Ren, C., Lei, M., Ran, W., \& Marett, E. G. (2017). The entertainment-education strategy in sexual assault prevention: A comparison of theoretical foundations and a test of effectiveness in a college campus setting. Journal of Health Communication, 22(9), 721-731. http://doi.org/10.1080/10810730.2017.1343877

Hwang, W.-Y., Chen, H. S. L., Shadiev, R., Huang, R. Y.-M., \& Chen, C.-Y. (2014). Improving English as a foreign language writing in elementary schools using mobile devices in familiar situational contexts. Computer Assisted Language Learning, 27(5), 359-378. http://doi.org/10.1080/09588221.2012.733711

Igartua, J.-J. (2006). Métodos cuantitativos de investigación en comunicación.

$$
\sim 258 \sim
$$


Barcelona: Bosch.

Igartua, J.-J. (2010). Identification with characters and narrative persuasion through fictional feature films. Communications, 35(4), 347-373. http://doi.org/10.1515/comm.2010.019

Igartua, J.-J. (2011). Mejor convencer entreteniendo??: comunicación para la salud y persuasión narrativa. Revista de Comunicación y Salud, 1, 69-83.

Igartua, J.-J. (2017). Comunicación para la salud y edu-entretenimiento. In U. Cuesta, C. Peñafiel, J. L. Terrón, E. Bustamante, \& S. Gaspar (Eds.), Comunicación y salud (pp. 161-181). Madrid: Dextra.

Igartua, J.-J., \& Barrios, I. (2012). Changing real-world beliefs with controversial movies: Processes and mechanisms of narrative persuasion. Journal of Communication, 62(3), 514-531. http://doi.org/10.1111/j.1460-2466.2012.01640.x

Igartua, J.-J., Cheng, L., \& Lopes, O. (2003). To think or not to think: Two pathways towards persuasion by short films on aids prevention. Journal of Health Communication, 8(6), 513-528. http://doi.org/10.108o/716100420

Igartua, J.-J., \& Fiuza, D. (2018). Persuading women against gender violence Persuading Women Against Gender Violence. Effect of Similarity with the Protagonist on Identification and Risk-Perception. Palabra Clave, 21(2), 499-523. http://doi.org/10.5294/pacla.2018.21.2.10

Igartua, J.-J., \& Frutos, F. J. (2017). Enhancing attitudes toward stigmatized groups with movies: Mediating and moderating processes of narrative persuasion. International Journal of Communication, 11(1), 158-177.

Igartua, J.-J., Guerrero-Martín, I., Cachón-Ramón, D., \& Rodríguez-de-Dios, I. (2018). Efecto de la similitud con el protagonista de narraciones contra el racismo en las actitudes hacia la inmigración. El rol mediador de la identificación con el protagonista. Anuario Electrónico de Estudios En Cominicación Social “Disertaciones," 11(1), 56-75. http://doi.org/10.12804/revistas.urosario.edu.co/disertaciones/vi1i1

Igartua, J.-J., \& Lozano, J. C. (2011). Narrative persuasion and cinematographic fiction. A cross-cultural study about the impact of the feature film, "A day withouth a Mexican" on attitudes toward inmigration. International Journal of Hispanic Psychology, 3(2), 237-250.

Igartua, J.-J., \& Rodríguez-de-Dios, I. (2016). Correlatos motivacionales del uso y la satisfacción con Facebook en jóvenes españoles. Cuadernos.Info, (38), 107-119. http://doi.org/10.7764/cdi.38.848

Igartua, J.-J., \& Vega Casanova, J. (2016). Identification with characters, elaboration, and counterarguing in entertainment-education interventions through 
RISKS OF INTERACTIVE COMMUNICATION IN ADOLESCENTS.

DIGITAL LITERACY DIAGNOSIS AND INTERVENTION

audiovisual fiction. Journal of Health Communication, 21(3), 293-300. http://doi.org/10.108o/10810730.2015.1064494

Igartua, J.-J., Wojcieszak, M., Cachón-Ramón, D., \& Guerrero-Martín, I. (2017). "If it hooks you, share it on social networks". Joint effects of character similarity and imagined contact on the intention to share a short narrative in favor of immigration. Revista Latina de Comunicacion Social, 72, 1085-1106. http://doi.org/10.4185/RLCS-2017-1209

Igartua, J.-J., Wojcieszak, M., \& Kim, N. (2018). How the interplay of imagined contact and first-person narratives improves attitudes toward stigmatized immigrants. A conditional process model. European Journal of Social Psychology, (May). http://doi.org/10.1002/ejsp.2509

Ihmeideh, F. M., \& Shawareb, A. A. (2014). The association between Internet parenting styles and children's use of the Internet at home. Journal of Research in Childhood Education, 28(4), 411-425. http://doi.org/10.1080/02568543.2014.944723

Ilomäki, L., Paavola, S., Lakkala, M., \& Kantosalo, A. (2016). Digital competence - an emergent boundary concept for policy and educational research. Education and Information Technologies, 21(3), 655-679. http://doi.org/10.1007/s10639-0149346-4

INE. (2017). Encuesta sobre equipamiento y uso de tecnologías de información y comunicación en los hogares. Retrieved from http://www.ine.es/prensa/tich_2017.pdf

Irving, L. M., Dupen, J., \& Berel, S. (1998). A media literacy program for high school females. Eating Disorders, 6(2), 119-131. http://doi.org/10.1080/10640269808251248

Iste. (2007). ISTE standards: Students. International Society for Technology in Education. Retrieved from http://www.iste.org/standards/istestandards/standards-for-students

ITU. (2017). Measuring the information society report 2017 - Volume 1. International Telecommunication Union (Vol. 1). http://doi.org/10.3359/ozo303157

Jackson, L. A., von Eye, A., Biocca, F. A., Barbatsis, G., Zhao, Y., \& Fitzgerald, H. E. (2006). Does home Internet use influence the academic performance of lowincome children? Developmental Psychology, 42(3), 429-435. http://doi.org/10.1037/oo12-1649.42.3.00o

Janssen, J., Stoyanov, S., Ferrari, A., Punie, Y., Pannekeet, K., \& Sloep, P. (2013). Experts' views on digital competence: Commonalities and differences. Computers $\mathcal{E}$ Education, 68, 473-481. http://doi.org/10.1016/j.compedu.2013.06.0o8 
Jeno, L. M., Grytnes, J.-A., \& Vandvik, V. (2017). The effect of a mobile-application tool on biology students' motivation and achievement in species identification: A Self-Determination Theory perspective. Computers \& Education, 107, 1-12. http://doi.org/10.1016/j.compedu.2016.12.011

Jensen, J. D., Yale, R. N., Krakow, M., John, K. K., \& King, A. J. (2017). Theorizing foreshadowed death narratives: Examining the impact of character death on narrative processing and skin self-exam intentions. Journal of Health Communication, 22(1), 84-93. http://doi.org/10.1080/10810730.2016.1252816

Jeong, S.-H., Cho, H., \& Hwang, Y. (2012). Media literacy interventions: A metaanalytic review. Journal of Communication, 62(3), 454-472. http://doi.org/10.1111/j.146o-2466.2012.01643.x

Jose, P. E., \& Brewer, W. F. (1984). The development of story liking: Character identification, suspense, and outcome resolution. Developmental Psychology, 20(5), 911-924.

Jou, M., Lin, Y.-T., \& Tsai, H.-C. (2016). Mobile APP for motivation to learning: an engineering case. Interactive Learning Environments, 24(8), 2048-2057. http://doi.org/10.1080/10494820.2015.1075136

Junta de Castilla y León. (2009). Plan de prevención del ciberacoso y promoción de la navegación segura en centros escolares. Guía de los alumnos. Junta de Castilla y León.

Kasurinen, J., \& Knutas, A. (2018). Publication trends in gamification: A systematic mapping study. Computer Science Review, 27, 33-44. http://doi.org/10.1016/j.cosrev.2017.10.003

Katzman, D. K. (2010). Sexting: Keeping teens safe and responsible in a technologically savvy world. Paediatrics and Child Health, 15(1), 41-42. http://doi.org/10.1093/pch/15.1.41

Kebritchi, M., Hirumi, A., \& Bai, H. (2010). The effects of modern mathematics computer games on mathematics achievement and class motivation. Computers E Education, 55(2), 427-443. http://doi.org/10.1016/j.compedu.2010.02.007

Khadka, S. (2018). A broad-based multiliteracies theory and praxis for a diverse writing classroom. Computers and Composition, 47, 93-110. http://doi.org/10.1016/j.compcom.2017.12.002

Khaleel, F. L., Sahari-Ashaari, N., Tengku Wook, T. S. M., \& Ismail, A. (2016). Gamification elements for learning applications. International Journal on Advanced Science, Engineering and Information Technology, 6(6), 868. http://doi.org/10.18517/ijaseit.6.6.1379

Khalid, M. Z., \& Ahmed, A. (2014). Entertainment-education media strategies for social 
RISKS OF INTERACTIVE COMMUNICATION IN ADOLESCENTS.

DIGITAL LITERACY DIAGNOSIS AND INTERVENTION

change: Opportunities and emerging trends. Review of Journalism and Mass Communication, 2(1), 69-89.

Khurana, A., Bleakley, A., Jordan, A. B., \& Romer, D. (2015). The protective effects of parental monitoring and Internet restriction on adolescents' risk of online harassment. Journal of Youth and Adolescence, 44(5), 1039-1047. http://doi.org/10.1007/s10964-014-0242-4

Kiger, D., Herro, D., \& Prunty, D. (2012). Examining the influence of a mobile learning intervention on third grade math achievement. Journal of Research on Technology in Education, 45(1), 61-82. http://doi.org/10.108o/15391523.2012.10782597

Kim, E. mee, \& Yang, S. (2016). Internet literacy and digital natives' civic engagement: Internet skill literacy or Internet information literacy? Journal of Youth Studies, 19(4), 438-456. http://doi.org/10.108o/13676261.2015.1083961

Kim, H. K., \& Shapiro, M. A. (2016). When bad things happen to a protagonist like you: the role of self in resistance to negatively framed health narratives. Journal of Health Communication, 21(12), 1227-1235. http://doi.org/10.108o/10810730.2016.1240268

Kim, Y., Sohn, D., \& Choi, S. M. (2011). Cultural difference in motivations for using social network sites: A comparative study of American and Korean college students. Computers in Human Behavior, 27(1), 365-372. http://doi.org/10.1016/j.chb.2010.08.015

Kirwil, L. (2009). Parental mediation of children's Internet use in different European countries. Journal of Children and Media, 3(4), 394-409. http://doi.org/10.1080/17482790903233440

Klettke, B., Hallford, D. J., \& Mellor, D. J. (2014). Sexting prevalence and correlates: A systematic literature review. Clinical Psychology Review, 34(1), 44-53. http://doi.org/10.1016/j.cpr.2013.10.007

Kline, R. (2013). Exploratory and confirmatory factor analysis. In Y. Petscher \& C. Schatsschneider (Eds.), Applied quantitative analysis in the social sciences (pp. 171-207). New York: Routledge.

Koc, M., \& Barut, E. (2016). Development and validation of New Media Literacy Scale (NMLS) for university students. Computers in Human Behavior, 63, 834-843. http://doi.org/10.1016/j.chb.2016.06.035

Koletić, G. (2017). Longitudinal associations between the use of sexually explicit material and adolescents' attitudes and behaviors: A narrative review of studies. $\begin{array}{llll}\text { Journal of } & \text { Adolescence, } & \text { 119-133. }\end{array}$ http://doi.org/10.1016/j.adolescence.2017.04.006 
Koltay, T. (2011). The media and the literacies: media literacy, information literacy, digital literacy. Media, Culture \& Society, 33(2), 211-221. http://doi.org/10.1177/0163443710393382

Kopaiboon, W., Reungtrakul, A., \& Wongwanich, S. (2014). Developing the quality of ICT competency instrument for lower secondary school students. Procedia Social and Behavioral Sciences, 116(2009), 1802-1809. http://doi.org/10.1016/j.sbspro.2014.01.475

Kosenko, K., Luurs, G., \& Binder, A. R. (2017). Sexting and sexual behavior, 2011-2015: A critical review and meta-analysis of a growing literature. Journal of ComputerMediated Communication, 22(3), 141-16o. http://doi.org/10.1111/jcc4.12187

Koutamanis, M., Vossen, H. G. M., Peter, J., \& Valkenburg, P. M. (2013). Practice makes perfect: The longitudinal effect of adolescents' instant messaging on their ability to initiate offline friendships. Computers in Human Behavior, 29(6), 2265-2272. http://doi.org/10.1016/j.chb.2013.04.033

Kowalski, R. M., Limber, S. P., \& McCord, A. (2018). A developmental approach to cyberbullying: Prevalence and protective factors. Aggression and Violent Behavior, (February), 1-13. http://doi.org/10.1016/j.avb.2018.02.009

Kowalski, R. M., Morgan, C. A., \& Limber, S. P. (2012). Traditional bullying as a potential warning sign of cyberbullying. School Psychology International, 33(5), 505-519. http://doi.org/10.1177/0143034312445244

Kowert, R., Vogelgesang, J., Festl, R., \& Quandt, T. (2015). Psychosocial causes and consequences of online video game play. Computers in Human Behavior, 45, 5158. http://doi.org/10.1016/j.chb.2014.11.074

Krahé, B. (2014). Media violence use as a risk factor for aggressive behaviour in adolescence. European Review of Social Psychology, 25(1), 71-106. http://doi.org/10.108o/10463283.2014.923177

Ktoridou, D., Eteokleous, N., \& Zahariadou, A. (2012). Exploring parents' and children's awareness on internet threats in relation to internet safety. CampusWide Information Systems, 29(3), 133-143. http://doi.org/10.1108/10650741211243157

Kuhlemeier, H., \& Hemker, B. (2007). The impact of computer use at home on students' Internet skills. Computers $\mathcal{E}$ Education, 49(2), 460-480. http://doi.org/10.1016/j.compedu.2005.10.004

Kupiainen, R., Suoninen, A., \& Nikunen, K. (2012). Between public and private: privacy in social networking sites. In S. Livingstone, L. Haddon, \& A. Görzig (Eds.), Children, Risk and Safety on the Internet. Research and policy challenges in comparative perspective (pp. 99-112). Bristol: The Policy Press. 
RISKS OF INTERACTIVE COMMUNICATION IN ADOLESCENTS.

DIGITAL LITERACY DIAGNOSIS AND INTERVENTION

Laespada, M. T. (2010). El discurso de los jóvenes en Internet. Bilbao: Universidad de Deusto.

Lam, C. W. C., \& Frydenberg, E. (2009). Coping in the cyberworld: Program implementation and evaluation - A pilot project. Australian Journal of Guidance and Counselling, 19(02), 196-215. http://doi.org/10.1375/ajgc.19.2.196

Lankshear, C., \& Knobel, M. (2008). Nuevos alfabetismos. Su práctica cotidiana y el aprendizaje en el aula. Madrid: Morata.

Lau, W. W. F., \& Yuen, A. H. K. (2013). Adolescents' risky online behaviours: The influence of gender, religion, and parenting style. Computers in Human Behavior, 29(6), 2690-2696. http://doi.org/10.1016/j.chb.2013.07.005

Lau, W. W. F., \& Yuen, A. H. K. (2014). Developing and validating of a perceived ICT literacy scale for junior secondary school students: Pedagogical and educational contributions. $\quad$ Computers $\mathcal{E} \quad$ Education, $\quad 78, \quad 1-9$. http://doi.org/10.1016/j.compedu.2014.04.016

Lazarinis, F. (2010). Online risks obstructing safe internet access for students. The Electronic Library, 28(1), 157-170. http://doi.org/10.1108/02640471011023441

Lazzari, M. (2016). Adolescenti e rischi di Internet?? la competenza digitale non basta. In Congresso Didamatica. Udine.

Lee, C., \& Shin, N. (2017). Prevalence of cyberbullying and predictors of cyberbullying perpetration among Korean adolescents. Computers in Human Behavior, 68, 352-358. http://doi.org/10.1016/j.chb.2016.11.047

Lee, S.-J. (2012). Parental restrictive mediation of children's internet use: Effective for what and for whom? New Media E Society, 15(4), 466-481. http://doi.org/10.1177/1461444812452412

Lee, S.-J., \& Chae, Y.-G. (2012). Balancing participation and risks in children's Internet use: The role of Internet literacy and parental mediation. Cyberpsychology, Behavior, and Social Networking, 15(5), 257-262. http://doi.org/10.1089/cyber.2011.0552

Lemmens, J. S., Valkenburg, P. M., \& Peter, J. (2009). Development and validation of a game addiction scale for adolescents. Media Psychology, 12(1), 77-95. http://doi.org/10.1080/15213260802669458

Len-Ríos, M. E., Hughes, H. E., McKee, L. G., \& Young, H. N. (2016). Early adolescents as publics: A national survey of teens with social media accounts, their media use preferences, parental mediation, and perceived Internet literacy. Public Relations Review, 42(1), 101-108. http://doi.org/10.1016/j.pubrev.2015.10.003

Lenhart, A. (2015). Teens, social media and technology overview 2015: Smartphones facilitate shifts in communication landscape for teens. Pew Research Center,

$$
\sim 264 \sim
$$


(April), 1-47. http://doi.org/10.1016/j.chb.2015.08.026

Lenhart, A., Maya, S., \& Graziano, M. (2001). The Internet and education: Findings of the Pew Internet $\mathcal{E}$ American life project. Retrieved from http://files.eric.ed.gov/fulltext/ED457849.pdf

Leung, L., \& Lee, P. S. N. (2012a). Impact of Internet literacy, Internet addiction symptoms, and Internet activities on academic performance. Social Science Computer Review, 3o(4), 403-418. http://doi.org/10.1177/o894439311435217

Leung, L., \& Lee, P. S. N. (2012b). The influences of information literacy, internet addiction and parenting styles on internet risks. New Media \& Society, 14(1), 117136. http://doi.org/10.1177/1461444811410406

Li, Y., \& Ranieri, M. (2010). Are 'digital natives' really digitally competent?-A study on Chinese teenagers. British Journal of Educational Technology, 41(6), 1029-1042. http://doi.org/10.1111/j.1467-8535.2009.01053.x

Liau, A. K., Khoo, A., \& Hwaang, P. (2005). Factors influencing adolescents engagement in risky Internet behavior. CyberPsychology \& Behavior, 8(6), 513520. http://doi.org/10.1089/cpb.2005.8.513

Liebert, R. M. (1986). Effects of television on children and adolescents. Developmental and Behavioral Pediatrics, 7(1), 43-48.

Lin, C. A. (2009). Effects of the Internet. In J. B. M. B. Oliver (Ed.), Media effects: advances in theory and research (3rd ed., pp. 567-591).

Ling, C., Harnish, D., \& Shehab, R. (2014). Educational apps: Using mobile applications to enhance student learning of statistical concepts. Human Factors and Ergonomics in Manufacturing \& Service Industries, 24(5), 532-543. http://doi.org/10.1002/hfm.20550

Liu, M., Scordino, R., Geurtz, R., Navarrete, C., Ko, Y., \& Lim, M. (2014). A look at research on mobile learning in K-12 education from 2007 to the present. Journal of Research on Technology in Education, 46(4), 325-372. http://doi.org/10.108o/15391523.2014.925681

Livingstone, S. (2004). What is media literacy? Intermedia, 32(3), 18-20.

Livingstone, S. (2013). Online risk, harm and vulnerability: Reflections on the evidence base for child Internet safety policy. Zer - Revista de Estudios de Comunicación, 18(35), 13-28. Retrieved from http://www.ehu.eus/zer/hemeroteca/pdfs/zer35o1-livingstone.pdf

Livingstone, S. (2017). Children's and young people's lives online. In J. Brown (Ed.), Online Risk to Children: Impact, Protection and Prevention (pp. 23-36). Chichester, UK: Wiley-Blackwell. 
RISKS OF INTERACTIVE COMMUNICATION IN ADOLESCENTS.

DIGITAL LITERACY DIAGNOSIS AND INTERVENTION

Livingstone, S., \& Görzig, A. (2012). "Sexting”: the exchange of sexual messages online among European youth. In S. Livingstone, L. Haddon, \& A. Görzig (Eds.), Children, Risk and Safety on the Internet. Research and policy challenges in comparative perspective (pp. 151-164). Bristol.

Livingstone, S., \& Haddon, L. (2012). Theoretical framework for children's internet use. In S. Livingstone, L. Haddon, \& A. Görzig (Eds.), Children, Risk and Safety on the Internet. Research and policy challenges in comparative perspective (pp. 1-14). Bristol: The Policy Press.

Livingstone, S., Haddon, L., \& Görzig, A. (2011). Risks and safety on the internet: The perspective of European children. London: EU Kids Online. Retrieved from www.eukidsonline.net

Livingstone, S., Haddon, L., Görzig, A., \& Ólafsson, K. (2011a). Risks and safety on the internet: The perspective of European children. Full findings. LSE, London: EU Kids Online. Retrieved from http://eprints.lse.ac.uk/33731/

Livingstone, S., Haddon, L., Görzig, A., \& Ólafsson, K. (2011b). Technical report and user guide: The 2010 EU Kids Online survey. LSE, London: EU Kids online. Retrieved from http://eprints.lse.ac.uk/45270/1/_Libfile_repository_Content_Livingstone $\% 2 \mathrm{C}$ S_Technical Report and User Guide EU Kids Online\%28author\%29.pdf

Livingstone, S., \& Helsper, E. J. (2008). Parental mediation of children's Internet use. Journal of Broadcasting $\mathcal{E}$ Electronic Media, 52(4), 581-599. http://doi.org/10.108o/o8838150802437396

Livingstone, S., \& Helsper, E. J. (2010). Balancing opportunities and risks in teenagers' use of the internet: the role of online skills and internet self-efficacy. New Media $\mathcal{E}$ Society, 12(2), 309-329. http://doi.org/10.1177/1461444809342697

Livingstone, S., Lemish, D., Lim, S. S., Bulger, M., Cabello, P., Claro, M., ... Wei, B. (2017). Global perspectives on children's digital opportunities: An emerging research and policy agenda. Pediatrics, 140(Supplement 2), S137-S141. http://doi.org/10.1542/peds.2016-1758S

Livingstone, S., Mascheroni, G., Dreier, M., Chaudron, S., \& Lagae, K. (2015). How parents of young children manage digital devices at home?]: The role of income, education and parental style. LSE, London: EU Kids Online.

Livingstone, S., Mascheroni, G., \& Staksrud, E. (2017). European research on children's internet use: Assessing the past and anticipating the future. New Media $\mathcal{E}$ Society, 1-20. http://doi.org/10.1177/1461444816685930

Livingstone, S., Ólafsson, K., Helsper, E. J., Lupiáñez-Villanueva, F., Veltri, G. A., \& Folkvord, F. (2017). Maximizing opportunities and minimizing risks for children online: The role of digital skills in emerging strategies of parental mediation.

$$
\sim 266 \sim
$$


Journal of Communication, 67, 82-105. http://doi.org/10.111//jcom.12277

Livingstone, S., Ólafsson, K., O’Neill, B., \& Donoso, V. (2012). Towards a better internet for children: findings and recommendations from EU Kids Online to inform the CEO coalition. LSE, London: EU Kids Online. Retrieved from http://eprints.lse.ac.uk/44213/

Livingstone, S., \& Smith, P. K. (2014). Annual research review: Harms experienced by child users of online and mobile technologies: The nature, prevalence and management of sexual and aggressive risks in the digital age. Journal of Child Psychology and Psychiatry and Allied Disciplines, 55(6), 635-654. http://doi.org/10.1111/jcpp.12197

Lonigro, A., Schneider, B. H., Laghi, F., Baiocco, R., Pallini, S., \& Brunner, T. (2014). Is cyberbullying related to trait or state anger? Child Psychiatry \& Human Development, 445-454. http://doi.org/10.1007/s10578-014-0484-o

Lu, A. S., Baranowski, T., Hong, S. L., Buday, R., Thompson, D., Beltran, A., ... Chen, T. A. (2016). The narrative impact of active video games on physical activity among children: A feasibility study. Journal of Medical Internet Research, 18(10). http://doi.org/10.2196/jmir.6538

$\mathrm{Lu}$, M. (2008). Effectiveness of vocabulary learning via mobile phone. Journal of Computer Assisted Learning, 24(6), 515-525. http://doi.org/10.1111/j.13652729.2008.00289.x

Luengo, J. A. (2011). Ciberbullying. Guía de recursos para centros educativos en casos de ciberacoso. Madrid: Defensor del Menor en la Comunidad de Madrid.

Lund, A. M. (2001). Measuring usability with the USE questionnaire. Usability Interface, 8(2), 3-6. http://doi.org/10.1177/1078087402250360

Lwin, M. O., Stanaland, A. J. S., \& Miyazaki, A. D. (2008). Protecting children's privacy online: How parental mediation strategies affect website safeguard effectiveness. Journal of Retailing, 84(2), 205-217. http://doi.org/10.1016/j.jretai.2008.04.004

Lyons, E. J., Baranowski, T., Basen-Engquist, K. M., Lewis, Z. H., Swartz, M. C., Jennings, K., \& Volpi, E. (2016). Testing the effects of narrative and play on physical activity among breast cancer survivors using mobile apps: study protocol for a randomized controlled trial. BMC Cancer, 16(1), 202. http://doi.org/10.1186/s12885-016-2244-y

Maccoby, E. E. (1951). Television: Its impact on school children. The Public Opinion Quarterly, 15(3), 421-444.

Machackova, H., Cerna, A., Sevcikova, A., Dedkova, L., \& Daneback, K. (2013). Effectiveness of coping strategies for victims of cyberbullying. Cyberpsychology: Journal of Psychosocial Research on Cyberspace, 7(3). 
RISKS OF INTERACTIVE COMMUNICATION IN ADOLESCENTS.

DIGITAL LITERACY DIAGNOSIS AND INTERVENTION

http://doi.org/10.5817/CP2013-3-5

Machmutow, K., Perren, S., Sticca, F., \& Alsaker, F. D. (2012). Peer victimisation and depressive symptoms: can specific coping strategies buffer the negative impact of cybervictimisation? Emotional and Behavioural Difficulties, 17(3-4), 403-420. http://doi.org/10.108o/13632752.2012.704310

Mackey, A. P., Hill, S. S., Stone, S. I., \& Bunge, S. A. (2011). Differential effects of reasoning and speed training in children. Developmental Science, 14(3), 582-590. http://doi.org/10.1111/j.1467-7687.2010.01005.x

Mahmoud, A. E.-B., \& Auter, P. J. (2009). The interactive nature of computer mediated communication. American Communication Journal, 11(4).

Mahmoudi, H., Koushafar, M., Saribagloo, J. A., \& Pashavi, G. (2015). The effect of computer games on speed, attention and consistency of learning mathematics among students. Procedia - Social and Behavioral Sciences, 176(March), 419-424. http://doi.org/10.1016/j.sbspro.2015.01.491

Maksl, A., Ashley, S., \& Craft, S. (2015). Measuring news media literacy. Journal of Media Literacy Education, 6(3), 29-45. Retrieved from http://digitalcommons.uri.edu/jmle/vol6/iss3/3/

Maksl, A., Craft, S., Ashley, S., \& Miller, D. (2017). The usefulness of a news media literacy measure in evaluating a news literacy curriculum. Journalism $\mathcal{E}$ Mass $\begin{array}{llll}\text { Communication } & \text { Educator, } & \text { 22(2), }\end{array}$ http://doi.org/10.1177/1077695816651970

Mares, M. L., Stephenson, L., Martins, N., \& Nathanson, A. I. (2018). A house divided: Parental disparity and conflict over media rules predict children's outcomes. Computers in Human Behavior, 81, 177-188. http://doi.org/10.1016/j.chb.2017.12.009

Martens, H. (2010). Evaluating media literacy education: Concepts, theories and future directions. Journal of Media Literacy Education, 2(1), 1-22. Retrieved from www.jmle.org

Martin, A. (2005). DigEuLit European framework for digital literacy: a progress report. Journal of ELiteracy, 2, 130-266. Retrieved from http://www.jelit.org/65/o1/JeLit_Paper_31.pdf?utm_source=twitterfeed\&utm_m edium=twitter

Martin, A. (2008). Digital literacy and the "digital society." In C. Lankshear \& M. Knobel (Eds.), Digital Literacies: Concepts, Policies \& Practices (pp. 151-176). New York: Peter Lang Publishing. http://doi.org/10.1093/elt/ccro77

Martin, F., \& Ertzberger, J. (2013). Here and now mobile learning: An experimental study on the use of mobile technology. Computers $\mathcal{E}$ Education, 68, 76-85.

$$
\sim 268 \sim
$$


http://doi.org/10.1016/j.compedu.2013.04.021

Martínez, G., \& Casado, M. Á. (2018). La responsabilidad de las madres y de los padres españoles como mediadores en el uso de Internet que hacen los menores: evolución y nuevos retos. In E. Jiménez, M. Garmendia, \& M. Á. Casado (Eds.), Entre selfies y whatsapps. Oportunidades y riesgos para la infancia y la adolescencia conectada (pp. 173-188). Barcelona: Gedisa.

Martínez, J. I., Cortés, A., Medrano, C., \& Apodaca, P. (2014). Internet use and parental mediation: A cross-cultural study. Computers $\mathcal{E}$ Education, 70, 212-221. http://doi.org/10.1016/j.compedu.2013.07.036

Marzouki, O. F., Idrissi, M. K., \& Bennani, S. (2017). Effects of social constructivist mobile learning environments on knowledge acquisition: A meta-analysis. International Journal of Interactive Mobile Technologies, 11(1), 18-39. http://doi.org/10.3991/ijim.v11i1.5982

Mascheroni, G., Murru, M. F., \& Görzig, A. (2012). Varieties of access and use. In S. Livingstone, L. Haddon, \& A. Görzig (Eds.), Children, Risk and Safety on the Internet. Research and policy challenges in comparative perspective (pp. 59-72). Bristol: The Policy Press.

Mascheroni, G., \& Ólafsson, K. (2014). Net Children Go Mobile: risks and opportunities (Second Edi). Milano: Educatt.

Mason, K. L. (2008). Cyberbullying: A preliminary assessment for school personnel. Psychology in the Schools, 45(4), 323-348. http://doi.org/10.1002/pits.20301

Massimini, M., \& Peterson, M. (2009). Information and communication technology?: Affects on U. S. college students. Cyberpsychology: Journal of Psychosocial Research on Cyberspace, 3(1).

Maybery, D., Steer, S., Reupert, A., \& Goodyear, M. (2009). The kids coping scale. Stress and Health, 25(1), 31-40. http://doi.org/10.1002/smi.1228

Mazzocco, P. J., Green, M. C., Sasota, J. A., \& Jones, N. W. (2010). This story is not for everyone: Transportability and narrative persuasion. Social Psychological and Personality Science, 1(4), 361-368. http://doi.org/10.1177/1948550610376600

McLean, S. A., Paxton, S. J., \& Wertheim, E. H. (2016). The role of media literacy in body dissatisfaction and disordered eating: A systematic review. Body Image, 19, 9-23. http://doi.org/10.1016/j.bodyim.2016.08.002

Meeder, R. (2005). Access denied: Internet filtering software in K-12 classrooms. TechTrends, 49(6), 56-58. http://doi.org/10.1007/BFo2763732

Meilan, Z., Trussell, R. P., Gallegos, B., \& Asam, R. R. (2015). Using math apps for improving student learning: An exploratory study in an inclusive fourth grade classroom. TechTrends, 59(2), 32-39. Retrieved from 
RISKS OF INTERACTIVE COMMUNICATION IN ADOLESCENTS.

DIGITAL LITERACY DIAGNOSIS AND INTERVENTION

http://web.a.ebscohost.com/ehost/pdfviewer/pdfviewer?sid=0457e5d5-62424644-bf59-e52856ac5884\%4osessionmgr40o2\&vid=15\&hid=4101

Mesa Agudelo, W. de J. (2012). Las TIC como herramientas potenciadoras de equidad, pertinencia e inclusión educativa. Trilogía, (7), 61-77.

Messias, E., Kindrick, K., \& Castro, J. (2014). School bullying, cyberbullying, or both: Correlates of teen suicidality in the 2011 CDC youth risk behavior survey. Comprehensive Psychiatry, 55(5), 1063-1068. http://doi.org/10.1016/j.comppsych.2014.02.005

Miller, B. C. (2002). Family influences on adolescent sexual and contraceptive behavior. The Journal of Sex Research, 39(1), 22-26. http://doi.org/10.1080/00224490209552115

Mishna, F., Cook, C., Saini, M., Wu, M.-J., \& MacFadden, R. (2011). Interventions to prevent and reduce cyber abuse of youth: A systematic review. Research on Social Work Practice, 21(1), 5-14. http://doi.org/10.1177/1049731509351988

Mitchell, K. J., Finkelhor, D., \& Wolak, J. (2003). The exposure of youth to unwanted sexual material on the Internet: A national survey of risk, impact, and prevention. Youth \& Society, 34(3), 330-358. http://doi.org/10.1177/0044118X02250123

Mitchell, K. J., Finkelhor, D., \& Wolak, J. (2005). Protecting youth online: Family use of filtering and blocking software. Child Abuse and Neglect, 29(7), 753-765. http://doi.org/10.1016/j.chiabu.2004.05.008

Monereo, C. (2005). Internet, un espacio idóneo para desarrollar las competencias básicas. In C. Monereo (Ed.), Internet y competencias básicas (pp. 5-26). Barcelona: Graó.

Montemayor, R. (1983). Parents and adolescents in conflict: All families some of the time and some families most of the time. Journal of Early Adolescence, 3(12), 83103.

Moreno, M. D. (2008). Digital literacy: full control of pen drive and mouse. Comunicar, 16(30), 137-146. http://doi.org/10.3916/c30-2008-02-007

Moyer-Gusé, E. (2008). Toward a theory of entertainment persuasion: Explaining the persuasive effects of entertainment-education messages. Communication Theory, 18(3), 407-425. http://doi.org/10.1111/j.1468-2885.2008.00328.x

Moyer-Gusé, E., Chung, A. H., \& Jain, P. (2011). Identification with characters and discussion of taboo topics after exposure to an entertainment narrative about sexual health. Journal of Communication, 61, 387-406. http://doi.org/10.1111/j.1460-2466.2011.01551.x

Moyer-Gusé, E., \& Nabi, R. L. (2010). Explaining the effects of narrative in an 
entertainment television program: Overcoming resistance to persuasion. Human Communication Research, 36, 26-52. http://doi.org/10.1111/j.14682958.2009.01367.X

Murias, K., Kwok, K., Castillejo, A. G., Liu, I., \& Iaria, G. (2016). The effects of video game use on performance in a virtual navigation task. Computers in Human Behavior, 58, 398-406. http://doi.org/10.1016/j.chb.2016.01.020

Murphy, S. T., Frank, L. B., Chatterjee, J. S., \& Baezconde-Garbanati, L. (2013). Narrative versus nonnarrative: The role of identification, transportation, and emotion in reducing health disparities. Journal of Communication, 63(1), 116-137. http://doi.org/10.1111/jcom.12007

Murphy, S. T., Frank, L. B., Moran, M. B., \& Patnoe-Woodley, P. (2011). Involved, transported, or emotional? Exploring the determinants of change in knowledge, attitudes, and behavior in entertainment-education. Journal of Communication, 61(3), 407-431. http://doi.org/10.1111/j.1460-2466.2011.01554.X

Naismith, L., Lonsdale, P., Vavoula, G., \& Sharples, M. (2004). Literature review in mobile technologies and learning. Educational Technology, 11, 1-25. http://doi.org/Retrived 13th March, 2014

Nan, X., Dahlstrom, M. F., Richards, A., \& Rangarajan, S. (2015). Influence of evidence type and narrative type on HPV risk perception and intention to obtain the HPV vaccine. Health Communication, 30(3), 301-308. http://doi.org/10.1080/10410236.2014.888629

Nan, X., Futerfas, M., \& Ma, Z. (2017). Role of narrative perspective and modality in the persuasiveness of public service advertisements promoting HPV vaccination. Health Communication, 32(3), 320-328. http://doi.org/10.1080/10410236.2016.1138379

Nantais, M., \& Cockerline, G. (2010). Internet filtering in schools: Protection or censorship? Journal of Curriculum and Pedagogy, 7(2), 51-53. http://doi.org/10.108o/15505170.2010.10471340

Nathanson, A. I. (2001). Parent and child perspectives on the presence and meaning of parental television mediation. Journal of Broadcasting E Electronic Media, 45(2), 201-220. http://doi.org/10.1207/s15506878jobem4502_1

$\mathrm{Ng}, \mathrm{W}$. (2012). Can we teach digital natives digital literacy? Computers $\mathcal{E}$ Education, 59(3), 1065-1078. http://doi.org/10.1016/j.compedu.2012.04.016

Nickerson, C., Rapanta, C., \& Goby, V. P. (2017). Mobile or not? Assessing the instructional value of mobile learning. Business and Professional Communication Quarterly, 8o(2), 137-153. http://doi.org/10.1177/2329490616663707

Nikken, P., \& Schols, M. (2015). How and why parents guide the media use of young 
RISKS OF INTERACTIVE COMMUNICATION IN ADOLESCENTS.

DIGITAL LITERACY DIAGNOSIS AND INTERVENTION

children. Journal of Child and Family Studies, 24(11), 3423-3435. http://doi.org/10.1007/s10826-015-0144-4

Nikou, S. A., \& Economides, A. A. (2017). Mobile-based assessment: Investigating the factors that influence behavioral intention to use. Computers $\mathcal{E}$ Education, 109, 56-73. http://doi.org/10.1016/j.compedu.2017.02.005

Nixon, C. (2014). Current perspectives: the impact of cyberbullying on adolescent health. Adolescent Health, Medicine and Therapeutics, 5, 143-158. http://doi.org/10.2147/AHMT.S36456

Noar, S. M. (2003). The role of structural equation modeling in scale development. Structural Equation Modeling: A Multidisciplinary Journal, 10(4), 622-647. http://doi.org/10.1207/S15328007SEM1004_8

Nocentini, A., Zambuto, V., \& Menesini, E. (2015). Anti-bullying programs and Information and Communication Technologies (ICTs): A systematic review. Aggression and Violent Behavior, 23, 52-60. http://doi.org/10.1016/j.avb.2015.05.012

Noguera, J. M., Jiménez, J. J., \& Osuna-Pérez, M. C. (2013). Development and evaluation of a $3 \mathrm{D}$ mobile application for learning manual therapy in the physiotherapy laboratory. Computers \& Education, 69, 96-108. http://doi.org/10.1016/j.compedu.2013.07.007

O’Neill, B. (2018). Las políticas relativas a la utilización de Internet por los menores. In E. Jiménez, M. Garmendia, \& M. Á. Casado (Eds.), Entre selfies y whatsapps. Oportunidades y riesgos para la infancia y la adolescencia conectada (pp. 107124). Barcelona: Gedisa.

O’Neill, B., Livingstone, S., \& McLaughlin, S. (2011). Final recommendations for policy, methodology and research. LSE, London: EU Kids online. http://doi.org/301

OECD. (2011). OECD Guide to measuring the information society 2011. Retrieved from www.oecd.org/sti/measuring-infoeconomy/guide

Ofcom. (2017). Children and parents: media use and attitudes report. Retrieved from http://stakeholders.ofcom.org.uk/binaries/research/media-literacy/media-useattitudes-14/Childrens_2014_Report.pdf

Ólafsson, K., Livingstone, S., \& Haddon, L. (2013). Children's use of online technologies in Europe. A review of the European evidence base. LSE, London: EU Kids Online.

ONTSI. (2013). La Sociedad en red. Informe Anual 2012. Madrid.

ONTSI. (2018a). Las TIC en los hogares españoles. Estudio de demanda y uso de Servicios de Telecomunicaciones y Sociedad de la Información.

ONTSI. (2018b). Perfil sociodemográfico de los internautas, análisis de datos INE 2017. 
Orel, A., Campbell, M., Wozencroft, K., Leong, E., \& Kimpton, M. (2017). Exploring university students' coping strategy intentions for cyberbullying. Journal of Interpersonal Violence, 32(3), 446-462. http://doi.org/10.1177/o886260515586363

Ortega-Ruiz, R., Del Rey, R., \& Casas, J. A. (2012). Knowing, building and living together on Internet and social networks : The ConRed cyberbullying prevention program. International Journal of Conflict and Violence, 6(2), 303-313.

Ouyang, X., Xin, T., \& Chen, F. (2016). Construct validity of the children's coping strategies Scale (CCSS): A bifactor model approach. Psychological Reports, 118(1), 199-218. http://doi.org/10.1177/o033294116628362

Overaa, J. M. (2014). Website blocked: Filtering technology in schools and school libraries. SLIS Student Research Journal, 4(2), 1-18.

Padilla, S., Rodríguez, E., Álvarez, M., Torres, A., Suárez, A., \& Rodrigo, M.-J. (2015). The influence of the family educational scenario on internet use of primary and secondary school children / La influencia del escenario educativo familiar en el uso de internet en los niños de primaria y secundaria. Infancia y Aprendizaje, 38(2), 402-434. http://doi.org/10.108o/o2103702.2015.1016749

Paik, H., \& Comstock, G. (1994). The effects of television violence on antisocial behavior: A meta-analysis. Communication Research, 21(4), 516-546.

Paiva, A., Dias, J., Sobral, D., Aylett, R., Woods, S., Hall, L., \& Zoll, C. (2005). Learning by feeling: Evoking empathy with synthetic characters. Applied Artificial Intelligence, 19(3-4), 235-266. http://doi.org/10.108o/08839510590910165

Palladino, B. E., Nocentini, A., \& Menesini, E. (2016). Evidence-based intervention against bullying and cyberbullying: Evaluation of the NoTrap! program in two independent trials. Aggressive Behavior, 42(2), 194-206. http://doi.org/10.1002/ab.21636

Park, S., \& Burford, S. (2013). A longitudinal study on the uses of mobile tablet devices and changes in digital media literacy of young adults. Educational Media International, 5o(4), 266-280. http://doi.org/10.1080/09523987.2013.862365

Park, Y. (2011). A pedagogical framework for mobile learning : categorizing educational applications of mobile technologies into four types. The International Review of Research in Open and Distributed Learning, 12(2), 1-13.

Park, Y. J. (2013). Digital literacy and privacy behavior online. Communication Research, 40(2), 215-236. http://doi.org/10.1177/o093650211418338

Pasquier, D., Simoes, J. A., \& Kredens, E. (2012). Agents of mediation and sources of safety awareness: a comparative overview. In S. Livingstone, L. Haddon, \& A. Görzig (Eds.), Children, Risk and Safety on the Internet. Research and policy challenges in comparative perspective (pp. 219-230). Bristol: The Policy Press. 
RISKS OF INTERACTIVE COMMUNICATION IN ADOLESCENTS. DIGITAL LITERACY DIAGNOSIS AND INTERVENTION

Patchin, J. W., \& Hinduja, S. (2010a). Changes in adolescent online social networking behaviors from 2006 to 2009. Computers in Human Behavior, 26, 818-1821. http://doi.org/10.1016/j.chb.2010.07.009

Patchin, J. W., \& Hinduja, S. (2010b). Cyberbullying and self-esteem. Journal of School Health, 8o(12), 614-621. http://doi.org/10.1111/j.1746-1561.2010.00548.x

Pechenkina, E., Laurence, D., Oates, G., Eldridge, D., \& Hunter, D. (2017). Using a gamified mobile app to increase student engagement, retention and academic achievement. International Journal of Educational Technology in Higher Education, 14(1), 31. http://doi.org/10.1186/s41239-017-0o69-7

Pérez-Escoda, A., Castro-Zubizarreta, A., \& Fandos-Igado, M. (2016). La competencia digital de la Generación Z: claves para su introducción curricular en la Educación Primaria. Comunicar, 24(49), 71-79. http://doi.org/10.3916/C49-2016-07

Peter, J., \& Valkenburg, P. M. (2006). Adolescents' exposure to sexually explicit online material and recreational attitudes toward sex. Journal of Communication, 56(4), 639-66o. http://doi.org/10.1111/j.146o-2466.2006.00313.x

Peter, J., \& Valkenburg, P. M. (2007). Adolescents' exposure to a sexualized media environment and their notions of women as sex objects. Sex Roles, 56, 381-395. http://doi.org/10.1007/s11199-0o6-9176-y

Peter, J., \& Valkenburg, P. M. (2008). Adolescents' exposure to sexually explicit Internet material and sexual preoccupancy: a three-wave panel study. Media Psychology, 11(2), 207-234. http://doi.org/10.1080/15213260801994238

Peter, J., \& Valkenburg, P. M. (2009). Adolescents' exposure to sexually explicit Internet material and sexual satisfaction: A longitudinal study. Human Communication Research, 35(2), 171-194. http://doi.org/10.1111/j.14682958.2009.01343.X

Peter, J., \& Valkenburg, P. M. (2010). Adolescents' use of sexually explicit internet material and sexual uncertainty: The role of involvement and gender. $\begin{array}{lll}\text { Communication } \quad \text { Monographs, } & \text { 37(3), }\end{array}$ http://doi.org/10.1080/03637751.2010.498791

Peter, J., \& Valkenburg, P. M. (2016). Adolescents and pornography: A review of 20 years of research. Journal of Sex Research, 53(4-5), 509-531. http://doi.org/10.108o/o0224499.2016.1143441

Peter, J., Valkenburg, P. M., \& Schouten, A. P. (2006). Characteristics and motives of adolescents talking with strangers on the Internet. CyberPsychology E Behavior, 9(5), 526-30. http://doi.org/10.1089/cpb.2006.9.526

Pinkleton, B. E., Austin, E. W., Chen, Y.-C. "Yvonnes," \& Cohen, M. (2013). Assessing effects of a media literacy-based intervention on US adolescents' responses to 
and interpretations of sexual media messages. Journal of Children and Media, 7(4), 463-479. http://doi.org/10.1080/17482798.2013.781512

Pinkleton, B. E., Austin, E. W., Cohen, M., Chen, Y. C., \& Fitzgerald, E. (20o8). Effects of a peer-led media literacy curriculum on adolescents' knowledge and attitudes toward sexual behavior and media portrayals of sex. Health Communication, 23(5), 462-472. http://doi.org/10.1080/10410230802342135

Pinkleton, B. E., Austin, E. W., Cohen, M., Miller, A., \& Fitzgerald, E. (2007). A statewide evaluation of the effectiveness of media literacy training to prevent tobacco use among adolescents. Health Communication, 21(1), 23-34. http://doi.org/10.108o/10410230701283306

Pino Juste, M. R., \& Soto Carballo, J. (2010). Identificación del dominio de competencias digitales en el alumnado del grado de magisterio. Teoría de La Educación: Educación y Cultura En La Sociedad de La Información, 11(3), 336-362. Retrieved from http://campus.usal.es/ revistas_trabajo/index.php/revistatesi/article/view/746 6

Potter, W. J. (2004). Theory of media literacy: A cognitive approach. Thousand Oaks, California: Sage Publications.

Potter, W. J. (2013). Review of literature on media literacy. Sociology Compass, 7(6), 417-435.

Protégeles, Daphne, Super Kids, \& Europea, C. (2013). Ciberbullying y privacidad. Guía para profesores. (A. Protégeles, Ed.). Madrid.

Pruulmann-Vengerfeldt, P., \& Runnel, P. (2012). Online opportunities. In S. Livingstone, L. Haddon, \& A. Görzig (Eds.), Children, risk and safety on the Internet. Research and policy challenges in comparative perspective (pp. 73-86). Bristol: The Policy Press.

Przybylski, A. K., \& Nash, V. (2017). Internet filtering technology and aversive online experiences in adolescents. Journal of Pediatrics, 184, 215-219.e1. http://doi.org/10.1016/j.jpeds.2017.01.063

Rafaeli, S. (1990). Interacting with media: parasocial interaction and real interaction. In B. D. Ruben \& L. A. Lievrouw (Eds.), Mediation, information and communication: Information and behavior (pp. 125-181). New Brunswick, NJ: Transaction.

Raskauskas, J., \& Huynh, A. (2015). The process of coping with cyberbullying: A systematic review. Aggression and Violent Behavior, 23, 118-125. http://doi.org/10.1016/j.avb.2015.05.019

Rasmussen, E. E., Ortiz, R. R., \& White, S. R. (2015). Emerging adults' responses to 
RISKS OF INTERACTIVE COMMUNICATION IN ADOLESCENTS.

DIGITAL LITERACY DIAGNOSIS AND INTERVENTION

active mediation of pornography during adolescence. Journal of Children and Media, 9(2), 16o-176. http://doi.org/10.108o/17482798.2014.997769

Reyns, B. W., Burek, M. W., Henson, B., \& Fisher, B. S. (2013). The unintended consequences of digital technology: Exploring the relationship between sexting and cybervictimization. Journal of Crime and Justice, 36(1), 1-17. http://doi.org/10.108o/0735648X.2011.641816

Rice, E., Rhoades, H., Winetrobe, H., Sanchez, M., Montoya, J., Plant, A., \& Kordic, T. (2012). Sexually explicit cell phone messaging associated with sexual risk among adolescents. Pediatrics, 130(4), 667-673. http://doi.org/10.1542/peds.2012-0021

Richardson, C. R., Resnick, P. J., Hansen, D. L., Derry, H. A., \& Rideout, V. J. (2002). Does pornography-blocking software block access to health information on the Internet? Journal of the American Medical Association, 288(22), 2887-2894. http://doi.org/10.1001/jama.288.22.2887

Riebel, J., Jäger, R. S., \& Fischer, U. C. (2009). Cyberbullying in Germany - an exploration of prevalence, overlapping with real life bullying and coping strategies. Psychology Science Quarterly, 21(3), 298-314. Retrieved from http://www.psychologie-aktuell.com/fileadmin/download/PschologyScience/32009/05_riebel.pdf

Riedl, M. O. (2010). A comparison of interactive narrative system approaches using human improvisational actors. In Proceedings of the Intelligent Narrative Technologies III Workshop on - INT3 'io (pp. 1-8). New York, New York, USA: ACM Press. http://doi.org/10.1145/1822309.1822325

Riel, J., Christian, S., \& Hinson, B. (2012). Charting digital literacy : A framework for information technology and digital skills education in the community college, (541), 1-22.

Rodríguez-de-Dios, I., \& Igartua, J.-J. (2014). Risks of interactive communication: A digital literacy proposal. Proceedings of the Second International Conference on Technological Ecosystems for Enhancing Multiculturality TEEM'14, 653-657. http://doi.org/10.1145/2669711.2669969

Rodríguez-de-Dios, I., \& Igartua, J.-J. (2016). Skills of digital literacy to address the risks of interactive communication. Journal of Information Technology Research (JITR), 9(1), 54-64. http://doi.org/10.4018/JITR.2016010104

Rodríguez-de-Dios, I., Igartua, J.-J., \& González-Vázquez, A. (2016). Development and validation of a digital literacy scale for teenagers. In Proceedings of the Fourth International Conference on Technological Ecosystems for Enhancing Multiculturality - TEEM '16 (pp. 1067-1072). New York, New York, USA: ACM Press. http://doi.org/10.1145/3012430.3012648

Rodríguez-de-Dios, I., van Oosten, J. M. F., \& Igartua, J.-J. (2018). A study of the $\sim 276 \sim$ 
relationship between parental mediation and adolescents' digital skills, online risks and online opportunities. Computers in Human Behavior, 82, 186-198. http://doi.org/10.1016/j.chb.2018.01.012

Rogers, E. M., Vaughan, P. W., Swalehe, R. M. A., Rao, N., Svenkerud, P., \& Sood, S. (1999). Effects of an entertainment-education radio soap opera on family planning behavior in Tanzania. Studies in Family Planning. http://doi.org/10.2307/172196

Røkenes, F. M., \& Krumsvik, R. J. (2016). Prepared to teach ESL with ICT? A study of digital competence in Norwegian teacher education. Computers $\mathcal{E}$ Education, 97, 1-20. http://doi.org/10.1016/j.compedu.2016.02.014

Romani, J. C. C. (2009). El concepto de tecnologías de la información. Benchmarking sobre las definiciones de las TIC en la sociedad del conocimiento. Zer - Revista de Estudios de Comunicación, 14, 285-318. http://doi.org/10.4067/So71813372003000200001

Roth, S., \& Cohen, L. (1986). Approach, avoidance, and coping with stress. American Psychologist, 41, 813-819. http://doi.org/10.1037/0003-066X.41.7.813

Rovolis, A., \& Tsaliki, L. (2012). Pornography. In S. Livingstone, L. Haddon, \& A. Görzig (Eds.), Children, risk and safety on the Internet. Research and policy challenges in comparative perspective (pp. 165-176). Bristol.

Sabina, C., Wolak, J., \& Finkelhor, D. (2008). The nature and dynamics of Internet pornography exposure for youth. CyberPsychology \& Behavior, 11(6), 691-693. http://doi.org/10.1089/cpb.2007.0179

Sailer, M., Hense, J., Mandl, H., \& Klevers, M. (2013). Psychological perspectives on motivation through gamification. Interaction Design and Architecture(s) Journal, (19), 28-37. http://doi.org/10.1177/1046878115627138

Salmivalli, C., Kärnä, A., \& Poskiparta, E. (2011). Counteracting bullying in Finland: The KiVa program and its effects on different forms of being bullied. International Journal of Behavioral Development, 35(5), 405-411. http://doi.org/10.1177/0165025411407457

Sánchez-Prieto, J. C., Olmos-Migueláñez, S., \& García-Peñalvo, F. J. (2014). Mobile learning adoption from informal into formal: an extended TAM model to measure mobile acceptance among teachers. In F. J. García-Peñalvo (Ed.), Proceedings of the Second International Conference on Technological Ecosystems for Enhancing Multiculturality (TEEM'14) (pp. 595-602). New York, USA. http://doi.org/10.1145/2669711.2669961

Sánchez-Prieto, J. C., Olmos-Migueláñez, S., \& García-Peñalvo, F. J. (2016). Informal tools in formal contexts: Development of a model to assess the acceptance of mobile technologies among teachers. Computers in Human Behavior, 55, 519- 
RISKS OF INTERACTIVE COMMUNICATION IN ADOLESCENTS.

DIGITAL LITERACY DIAGNOSIS AND INTERVENTION

528. http://doi.org/10.1016/j.chb.2015.07.002

Sandberg, J., Maris, M., \& De Geus, K. (2011). Mobile English learning: An evidencebased study with fifth graders. Computers \& Education, 57(1), 1334-1347. http://doi.org/10.1016/j.compedu.2011.01.015

Sangalang, A., Johnson, J. M. Q., \& Ciancio, K. E. (2013). Exploring audience involvement with an interactive narrative: Implications for incorporating transmedia storytelling into entertainment-education campaigns. Critical Arts, 27(1), 127-146. http://doi.org/10.1080/02560046.2013.766977

Sardi, L., Idri, A., \& Fernández-Alemán, J. L. (2017). A systematic review of gamification in e-Health. Journal of Biomedical Informatics, 71, 31-48. http://doi.org/10.1016/j.jbi.2017.05.011

Sasson, H., \& Mesch, G. (2014). Parental mediation, peer norms and risky online behavior among adolescents. Computers in Human Behavior, 33, 32-38. http://doi.org/10.1016/j.chb.2013.12.025

Schneider, S. K., O’Donnell, L., Stueve, A., \& Coulter, R. W. S. (2012). Cyberbullying, school bullying, and psychological distress: A regional census of high school students. American Journal of Public Health, 102(1), 171-177. http://doi.org/10.2105/AJPH.2011.300308

Schutte, N. S., Malouff, J. M., Post-Gorden, J. C., \& Rodasta, A. L. (1988). Effects of playing videogames on children's aggressive and other behaviors. Journal of Applied Social Psychology, 18(5), 454-46o.

Scolari, C. A. (2008). Hipermediaciones: elementos para una Teoría de la Comunicación Digital Interactiva. Barcelona: Gedisa.

Scolari, C. A. (2018). Introduction: from media literacy to transmedia literacy. In C. A. Scolari (Ed.), Teens, media and collaborative cultures. Exploiting teens' transmedia skills in the classroom (pp. 12-20). Barcelona: Ge.Ge.

Seiffge-Krenke, I., \& Shulman, S. (1990). Coping style in adolescence. Journal of CrossCultural Psychology, 21(3), 351-377.

Sevillano, M. L. (2009). Competencias para el uso de herramientas virtuales en la vida, trabajo y formación permanentes. Madrid: Pearson.

Shapiro, J. J., \& Hughes, S. K. (1996). Information literacy as a liberal art: Enlightenment proposals for a new curriculum. Educom Review, 31(2), 159-162. Retrieved

from http://net.educause.edu/apps/er/review/reviewArticles/31231.html

Sharifi, M., Rostami AbuSaeedi, A. A., Jafarigohar, M., \& Zandi, B. (2017). Retrospect and prospect of computer assisted English language learning: a meta-analysis of the empirical literature. Computer Assisted Language Learning, 8221, 1-24.

$$
\sim 278 \sim
$$


http://doi.org/10.108o/o9588221.2017.1412325

Shek, D. T. L., \& Ma, C. M. S. (2012). Consumption of pornographic materials among early adolescents in Hong Kong: profiles and psychosocial correlates. International Journal on Disability and Human Development, 11(2), 143-150. http://doi.org/10.1515/ijdhd-2012-0024

Shen, F., \& Han, J. (Ashley). (2014). Effectiveness of entertainment education in communicating health information: a systematic review. Asian Journal of Communication, 24(6), 605-616. http://doi.org/10.108o/01292986.2014.927895

Shen, F., Sheer, V. C., \& Li, R. (2015). Impact of narratives on persuasion in health communication: A meta-analysis. Journal of Advertising, 44(2), 105-113. http://doi.org/10.108o/oog13367.2015.1018467

Shen, L., Seung, S., Andersen, K. K., \& Mcneal, D. (2017). The psychological mechanisms of persuasive impact from narrative communication. Studies in Communication $\quad$ Sciences, $\quad 17(2), \quad 165^{-181}$. http://doi.org/10.24434/j.scoms.2017.02.003

Shin, W., Huh, J., \& Faber, R. J. (2012). Tweens' online privacy risks and the role of parental mediation. Journal of Broadcasting E Electronic Media, 56(4), 632-649. http://doi.org/10.108o/o8838151.2012.732135

Shin, W., \& Ismail, N. (2014). Exploring the role of parents and peers in young adolescents' risk taking on social networking sites. Cyberpsychology, Behavior, and Social Networking, 17(9), 578-583. http://doi.org/10.1089/cyber.2014.0095

Shin, W., \& Kang, H. (2016). Adolescents' privacy concerns and information disclosure online: The role of parents and the Internet. Computers in Human Behavior, 54, 114-123. http://doi.org/10.1016/j.chb.2015.07.062

Shin, Y. J., Miller-Day, M., Hecht, M. L., \& Krieger, J. L. (2017). Entertainmenteducation videos as a persuasive tool in the substance use prevention intervention “keepin' it REAL”. Health Communication, oo(oo), 1-11. http://doi.org/10.108o/10410236.2017.1321163

Siddiq, F., Hatlevik, O. E., Olsen, R. V., Throndsen, I., \& Scherer, R. (2016). Taking a future perspective by learning from the past - A systematic review of assessment instruments that aim to measure primary and secondary school students' ICT literacy. Educational Research Review, 19, 58-84. http://doi.org/10.1016/j.edurev.2016.05.002

Šimandl, V., \& Vaníček, J. (2017). Influences on ICT teachers knowledge and routines in a technical e-safety context. Telematics and Informatics, 34, 1488-1502. http://doi.org/10.1016/j.tele.2017.06.012

Singh, M. M., Ng, P. J., Yap, K. M., Husin, M. H., \& Malim, N. H. A. H. (2017). 
RISKS OF INTERACTIVE COMMUNICATION IN ADOLESCENTS.

DIGITAL LITERACY DIAGNOSIS AND INTERVENTION

Cyberbullying and a mobile game app? An initial perspective on an alternative solution. Journal of Information Processing Systems, 13(3), 559-572. http://doi.org/10.3745/JIPS.04.0033

Singhal, A., Obregon, R., \& Rogers, E. M. (1994). Reconstructing the story of Simplemente María, the most popular telenovela in Latin America of all time. Gazette, 54, 1-15.

Singhal, A., \& Rogers, E. M. (2002). A theoretical agenda for entertainment- education. Communication Theory, 12(March), 117-135. http://doi.org/10.1111/j.14682885.2002.tboo262.x

Singhal, A., Rogers, E. M., \& Brown, W. J. (1993a). Entertainment telenovelas for development: lessons learned. In A. Fadul (Ed.), Serial Fiction in TV: The Latin America Telenovelas. Sao Paulo, Brasil: Escola de Communicaçoes e Artes, Universidade de Sao Paulo.

Singhal, A., Rogers, E. M., \& Brown, W. J. (1993b). Harnessing the potential of entertainment-education telenovelas. Gazette, 51, 1-18.

Sittichai, R., \& Smith, P. K. (2018). Bullying and cyberbullying in Thailand: Coping strategies and relation to age, gender, religion and victim status. Journal of New Approaches in Educational Research, 7(1), 24-30. http://doi.org/10.7821/naer.2018.1.254

Skinner, E. A., Edge, K., Altman, J., \& Sherwood, H. (2003). Searching for the structure of coping: A review and critique of category systems for classifying ways of coping. Psychological Bulletin, 129(2), 216-269. http://doi.org/10.1037/00332909.129.2.216

Slater, M. D. (2003). Alienation, aggression, and sensation seeking as predictors of adolescent use of violent film, computer, and website content. Journal of Communication, 53(1), 105-121.

Slater, M. D., \& Rouner, D. (2002). Entertainment-Education and elaboration likelihood: Understanding the processing of narrative persuasion. Communication Theory, 12(2), 173-191. http://doi.org/10.1111/j.14682885.2002.tboo265.x

Sléglová, V., \& Cerná, A. (2011). Cyberbullying in adolescents victims: Perception and coping. Cyberpsychology: Journal of Psychosocial Research on Cyberspace, 5(2), 1-16. Retrieved from http://www.cyberpsychology.eu/view.php? cisloclanku=2011121901\&article $=4$

Smahel, D., \& Wright, M. F. (2014). The meaning of online problematic situations for children. Results of qualitative cross-cultural investigation in nine European countries. London: EU Kids online. 
Sonck, N., \& de Haan, J. (2013). How the Internet skills of European 11- to 16-year-olds mediate between online risk and harm. Journal of Children and Media, 7(1), 7995. http://doi.org/10.108o/17482798.2012.739783

Sonck, N., \& de Haan, J. (2014). Safety by literacy? Rethinking the role of digital skills in improving online safety. In Minding Minors Wandering the Web: Regulating Online Child Safety (pp. 89-104). http://doi.org/10.1007/978-94-6265-005-3_5

Sonck, N., Kuiper, E., \& de Haan, J. (2012). Digital skills in the context of media literacy. In S. Livingstone, L. Haddon, \& A. Görzig (Eds.), Children, Risk and Safety on the Internet. Research and policy challenges in comparative perspective (pp. 87-98). Bristol: The Policy Press.

Sonck, N., Livingstone, S., Kuiper, E., \& de Haan, J. (2011). Digital literacy and safety skills. London School of Economics \& Political Science, London: EU Kids Online.

Sorbring, E. (2014). Parents' concerns about their teenage children's Internet use. Journal of Family Issues, 35(1), 75-96. http://doi.org/10.1177/0192513X12467754

Soto-Sanfiel, M. T., Aymerich-Franch, L., \& Ribes Guàrdia, F. X. (2010). Impacto de la interactividad en la identificación con los personajes de las ficciones. Psicothema, 22(4), 822-827.

Spitzberg, B. H. (2006). Preliminary development of a model and measure of computer-mediated communication (CMC) competence. Journal of ComputerMediated Communication, 11(2), 629-666. http://doi.org/10.1111/j.10836101.2006.00030.x

Staksrud, E., Ólafsson, K., \& Livingstone, S. (2013). Does the use of social networking sites increase children's risk of harm? Computers in Human Behavior, 29(1), 4050. http://doi.org/10.1016/j.chb.2012.05.026

Stavrositu, C. D., \& Kim, J. (2015). All blogs are not created equal: The role of narrative formats and user-generated comments in health prevention. Health Communication, 30(5), 485-495. http://doi.org/10.108o/10410236.2013.867296

Stehr, N. (2015). History of knowledge society. International encyclopedia of the social $\mathcal{E}$ behavioral sciences: Second Edition (Second Edi, Vol. 13). Elsevier. http://doi.org/10.1016/B978-o-o8-097086-8.03160-3

Steinberg, L., \& Morris, A. S. (2001). Adolescent development. Annual Review of Psychology, 52, 83-110. http://doi.org/10.1146/annurev.psych.52.1.83

Stevenson, M. E., \& Hedberg, J. G. (2017). Mobilizing learning: a thematic review of apps in K-12 and higher education. Interactive Technology and Smart Education, 14(2), 126-137. http://doi.org/10.1108/ITSE-02-2017-0017

Strassberg, D. S., McKinnon, R. K., Sustaíta, M. A., \& Rullo, J. (2013). Sexting by high school students: An exploratory and descriptive study. Archives of Sexual 
RISKS OF INTERACTIVE COMMUNICATION IN ADOLESCENTS.

DIGITAL LITERACY DIAGNOSIS AND INTERVENTION

Behavior, 42(1), 15-21. http://doi.org/10.1007/s10508-012-9969-8

Štulhofer, A., Buško, V., \& Landripet, I. (2010). Pornography, sexual socialization, and satisfaction among young men. Archives of Sexual Behavior, 39(1), 168-178. http://doi.org/10.1007/s10508-008-9387-o

Su, C. H., \& Cheng, C. H. (2015). A mobile gamification learning system for improving the learning motivation and achievements. Journal of Computer Assisted Learning, 31(3), 268-286. http://doi.org/10.1111/jcal.12088

Subrahmanyam, K., \& Greenfiel, P. (2008). Online communication and adolescent relationship. Journal of Applied Developmental Psychology, 29(1), 420-433. http://doi.org/10.1353/foc.0.00o6

Sumter, S. R., Valkenburg, P. M., Baumgartner, S. E., Peter, J., \& van der Hof, S. (2015). Development and validation of the multidimensional offline and online peer victimization scale. Computers in Human Behavior, 46, 114-122. http://doi.org/10.1016/j.chb.2014.12.042

Sung, Y.-T., Chang, K.-E., \& Liu, T.-C. (2016). The effects of integrating mobile devices with teaching and learning on students' learning performance: A meta-analysis and research synthesis. Computers $\mathcal{E}$ Education, 94, 252-275. http://doi.org/10.1016/j.compedu.2015.11.008

Süss, D. (2001). Computers and the Internet in school: Closing the knowledge gap? In S. Livingstone \& M. Bovill (Eds.), Children and Their Changing Media Environment (pp. 221-244). Mahway, NJ: Laerence Erlbaum Associates.

Symons, K., Ponnet, K., Emmery, K., Walrave, M., \& Heirman, W. (2017). Parental knowledge of adolescents' online content and contact risks. Journal of Youth and Adolescence, 46, 401-416. http://doi.org/10.1007/s10964-016-0599-7

Taylor, L. M., Casto, D. J., \& Walls, R. T. (2007). Learning with versus without technology in elementary and secondary school. Computers in Human Behavior, 23(1), 798-811. http://doi.org/10.1016/j.chb.2004.11.010

Teimouri, M., Hassan, M. S., Bolong, J., Daud, A., Yussuf, S., \& Adzharuddin, N. A. (2014). What is upsetting our children online? Procedia - Social and Behavioral Sciences, 155(October), 411-416. http://doi.org/10.1016/j.sbspro.2014.10.314

Tejedor, S., \& Pulido, C. (2012). Challenges and risks of internet use by children. How to empower minors? Comunicar, 20(39), 65-72. http://doi.org/10.3916/C39-201202-06

Teri, S., Acai, A., Griffith, D., Mahmoud, Q., Ma, D. W. L., \& Newton, G. (2014). Student use and pedagogical impact of a mobile learning application. Biochemistry and Molecular Biology Education, 42(2), 121-135. http://doi.org/10.1002/bmb.20771

Terras, M. M., \& Ramsay, J. (2016). Family digital literacy practices and children's 
mobile phone use. Frontiers in Psychology, 7, 1-11. http://doi.org/10.3389/fpsyg.2016.01957

Thinley, P., Geva, S., \& Reye, J. (2014). Tablets (iPad) for M-Learning in the context of social constructivism to institute an effective learning environment Palmo. International Journal of Interactive Mobile Technologies (IJIM), 8(1), 16. http://doi.org/10.3991/ijim.v8i1.3452

Thompson, S. (2003). Information literacy meeting of experts, Prague, the Czech Republic, September 20-23, 2003, Conference report. Retrieved from http://www.unesco.org/fileadmin/MULTIMEDIA/HQ/CI/CI/pdf/themes/info_ lit_meeting_prague_2003.pdf

Tingir, S., Cavlazoglu, B., Caliskan, O., Koklu, O., \& Intepe-Tingir, S. (2017). Effects of mobile devices on $\mathrm{K}-12$ students' achievement: a meta-analysis. Journal of Computer Assisted Learning, 33(4), 355-369. http://doi.org/10.1111/jcal.12184

Tobin, D. L., Holroyd, K. A., Reynolds, R. V, \& Wigal, J. K. (1989). The hierarchical factor structure of the Coping Strategies Inventory. Cognitive Therapy $\mathcal{E}$ Research, 13(4), 343-361. Retrieved from http://ezproxy.lib.utexas.edu/login?url=http://search.ebscohost.com/login.asp $\mathrm{x}$ ?direct $=$ true $\& \mathrm{db}=$ psyhref\&AN=CTR.AC.CDC.TOBIN.HFSCS

Tolsá, J. (2012). Los menores y el mercado de las pantallas: una propuesta de conocimiento integrado. Madrid: Foro Generaciones Interactivas.

Tomczyk, Ł. (2017). Cyberbullying in 2010 and 2015 - A perspective on the changes in the phenomenon among adolescents in Poland in the context of preventive action. Children and Youth Services Review, 75, 50-6o. http://doi.org/http://dx.doi.org/10.1016/j.childyouth.2017.02.017

Trepte, S., Masur, P. K., \& Scharkow, M. (2017). Mutual friends' social support and selfdisclosure in face-to-face and instant messenger communication. Journal of Social Psychology, o(o), 1-16. http://doi.org/10.108o/o0224545.2017.1398707

Tsai, M.-J., \& Tsai, C. C. (2010). Junior high school students' Internet usage and selfefficacy: A re-examination of the gender gap. Computers $\mathcal{E}$ Education, 54(4), 1182-1192. http://doi.org/10.1016/j.compedu.2009.11.004

Tsai, T. H., Wei, C. H., \& Tsai, C. Y. (2014). Investigating parental intention of using internet filter software. Quality and Quantity, 48(1), 75-89. http://doi.org/10.1007/s11135-012-9750-z

Tukachinsky, R. (2014). Experimental manipulation of psychological involvement with media. Communication Methods and Measures, 8(1), 1-33. http://doi.org/10.108o/19312458.2013.873777

Valcke, M., Bonte, S., De Wever, B., \& Rots, I. (2010). Internet parenting styles and the 
RISKS OF INTERACTIVE COMMUNICATION IN ADOLESCENTS.

DIGITAL LITERACY DIAGNOSIS AND INTERVENTION

impact on Internet use of primary school children. Computers $\mathcal{E}$ Education, 55(2), 454-464. http://doi.org/10.1016/j.compedu.2010.02.009

Valcke, M., De Wever, B., Van Keer, H., \& Schellens, T. (2011). Long-term study of safe Internet use of young children. Computers \& Education, 57(1), 1292-1305. http://doi.org/10.1016/j.compedu.2011.01.010

Valkenburg, P. M., Krcmar, M., Peeters, A. L., \& Marseille, N. M. (1999). Developing a scale to assess three styles of television mediation:"Instructive mediation,"'restrictive mediation," and "social coviewing". Journal of Broadcasting $\mathcal{E} \quad$ Electronic Media, 43(1), 52-66. http://doi.org/10.108o/o8838159909364474

Valkenburg, P. M., \& Peter, J. (2009). Social consequences of the Internet for adolescents. A decade of research. Current Directions in Psychological Science, 18(1), 1-5. http://doi.org/10.1111/j.1467-8721.2009.01595.x

Valkenburg, P. M., \& Peter, J. (2011). Online communication among adolescents: An integrated model of its attraction, opportunities, and risks. Journal of Adolescent Health, 48(2), 121-127. http://doi.org/10.1016/j.jadohealth.2010.08.020

Valkenburg, P. M., \& Peter, J. (2013). The differential susceptibility to media effects model. Journal of Communication, 63(2), 221-243. http://doi.org/10.1111/jcom.12024

Valkenburg, P. M., \& Piotrowski, J. T. (2017). Plugged in: how media attract and affect youth. USA: Yale University Press.

Valkenburg, P. M., Piotrowski, J. T., Hermanns, J., \& de Leeuw, R. (2013). Developing and validating the perceived parental media mediation scale: A selfdetermination perspective. Human Communication Research, 39(4), 445-469. http://doi.org/10.1111/hcre.12010

Valkenburg, P. M., \& Soeters, K. E. (2001). Children's positive and negative experiences with the Internet: An exploratory survey. Communication Research, 28(5), 652675 .

van den Heuvel, A., van den Eijnden, R. J. J. M., van Rooij, A. J., \& van de Mheen, D. (2012). Meeting online contacts in real life among adolescents: The predictive role of psychosocial wellbeing and internet-specific parenting. Computers in Human Behavior, 28(2), 465-472. http://doi.org/10.1016/j.chb.2011.10.018

van der Schuur, W. A., Baumgartner, S. E., Sumter, S. R., \& Valkenburg, P. M. (2015). The consequences of media multitasking for youth: A review. Computers in Human Behavior, 53, 204-215. http://doi.org/10.1016/j.chb.2015.06.035

van Deursen, A. J. A. M., Helsper, E. J., \& Eynon, R. (2014). Measuring digital skills. From digital skills to tangible outcomes project report. Retrieved from

$$
\sim 284 \sim
$$


www.oii.ox.ac.uk/research/projects/?id=112

van Deursen, A. J. A. M., Helsper, E. J., \& Eynon, R. (2015). Development and validation of the Internet Skills Scale (ISS). Information, Communication E Society, 1-20. http://doi.org/10.1080/1369118X.2015.1078834

van Deursen, A. J. A. M., van Dijk, J. A. G. M., \& Peters, O. (2012). Proposing a survey instrument for measuring operational, formal, information, and strategic Internet skills. International Journal of Human-Computer Interaction, 28(12), 827-837. http://doi.org/10.1080/10447318.2012.670086

van Laar, E., van Deursen, A. J. A. M., van Dijk, J. A. G. M., \& de Haan, J. (2017). The relation between 21 st -century skills and digital skills or literacy: A systematic literature review. Computers in Human Behavior, 72(May), 577-588. http://doi.org/10.1016/j.chb.2017.03.010

van Leeuwen, L., Renes, R. J., \& Leeuwis, C. (2013). Televised entertainment-education to prevent adolescent alcohol use: Perceived realism, enjoyment, and impact. Health Education and Behavior, 40(2), 193-205. http://doi.org/10.1177/1090198112445906

van Leeuwen, L., van den Putte, B., Renes, R. J., \& Leeuwis, C. (2017). Do narrative engagement and recipients' thoughts explain the impact of an entertainmenteducation narrative on discouraging binge drinking? Media Psychology, 2o(2), 194-220. http://doi.org/10.1080/15213269.2016.1142379

van Oosten, J. M. F., Peter, J., \& Vandenbosch, L. (2017). Adolescents' sexual media use and willingness to engage in casual sex: Differential relations and underlying processes. Human Communication Research, 43(1), 127-147. http://doi.org/10.1111/hcre.12098

van Oosten, J. M. F., \& Vandenbosch, L. (2017). Sexy online self-presentation on social network sites and the willingness to engage in sexting: A comparison of gender and age. Journal of Adolescence, 54, 42-50. http://doi.org/10.1016/j.adolescence.2016.11.006

van Ouytsel, J., Ponnet, K., Walrave, M., \& D’Haenens, L. (2017). Adolescent sexting from a social learning perspective. Telematics and Informatics, 34(1), 287-298. http://doi.org/10.1016/j.tele.2016.05.009

van Ouytsel, J., van Gool, E., Walrave, M., Ponnet, K., \& Peeters, E. (2017). Sexting: adolescents' perceptions of the applications used for, motives for, and consequences of sexting. Journal of Youth Studies, 20(4), 446-470. http://doi.org/10.108o/13676261.2016.1241865

van Ouytsel, J., Walrave, M., Ponnet, K., \& Heirman, W. (2015). The association between adolescent sexting, psychosocial difficulties, and risk behavior: integrative review. The Journal of School Nursing, 31(1), 54-69. 
RISKS OF INTERACTIVE COMMUNICATION IN ADOLESCENTS.

DIGITAL LITERACY DIAGNOSIS AND INTERVENTION

http://doi.org/10.1177/1059840514541964

Vanden Abeele, M., Campbell, S. W., Eggermont, S., \& Roe, K. (2014). Sexting, mobile porn use, and peer group dynamics: Boys' and girls' self-perceived popularity, need for popularity, and perceived peer pressure. Media Psychology, 17(1), 6-33. http://doi.org/10.108o/15213269.2013.801725

Vandenbosch, L., \& Eggermont, S. (2013). Sexually explicit websites and sexual initiation: Reciprocal relationships and the moderating role of pubertal status.

Journal of Research on Adolescence, 23(4), 621-634. http://doi.org/10.1111/jora.12008

Vandenbosch, L., \& van Oosten, J. M. F. (2018). Explaining the relationship between sexually explicit Internet material and casual sex: A two-step mediation model of perceived utility and instrumental attitudes. Archives of Sexual Behavior.

Vanderhoven, E., Schellens, T., \& Valcke, M. (2014a). Educating teens about the risks on social network sites. An intervention study in secondary education. Comunicar, 22(43), 123-131. http://doi.org/10.3916/C43-2014-12

Vanderhoven, E., Schellens, T., \& Valcke, M. (2014b). Educational packages about the risks on social network sites: State of the art. Procedia - Social and Behavioral Sciences, 112(January 2013), 603-612. http://doi.org/10.1016/j.sbspro.2014.01.1207

Vanderhoven, E., Schellens, T., \& Valcke, M. (2015). How authentic should a learning context be? Using real and simulated profiles in a classroom intervention to improve safety on social network sites. International Journal of Cyber Society and Education, 8(1), 1-18. http://doi.org/10.7903/ijcse.1200

Vanderhoven, E., Schellens, T., Vanderlinde, R., \& Valcke, M. (2016). Developing educational materials about risks on social network sites: a design based research approach. Educational Technology Research and Development, 64(3), 459-48o. http://doi.org/10.1007/s11423-015-9415-4

Vandoninck, S. (2016). Dealing with online risks: how to develop adequate coping strategies and preventive measures with a focus on vulnerable children. KU Leuven.

Vandoninck, S., \& d'Haenens, L. (2015). Children's online coping strategies: Rethinking coping typologies in a risk-specific approach. Journal of Adolescence, 45, 225-236. http://doi.org/10.1016/j.adolescence.2015.10.007

Vandoninck, S., \& d'Haenens, L. (2018). Resiliencia online: la capacidad de minimizar el impacto de los riesgos y de gestionar las situaciones potencialmente dañinas en Internet. In E. Jiménez, M. Garmendia, \& M. Á. Casado (Eds.), Entre selfies y whatsapps. Oportunidades y riesgos para la infancia y la adolescencia conectada (pp. 189-208). Barcelona: Gedisa. 
Vandoninck, S., d'Haenens, L., \& Donoso, V. (2010). Digital literacy of flemish youth: How do they handle online content risks? Communications, 35(4), 397-416. http://doi.org/10.1515/COMM.2010.021

Vandoninck, S., d'Haenens, L., \& Roe, K. (2013). Online Risks: Coping strategies of less resilient children and teenagers across Europe. Journal of Children and Media, 7(1), 6o-78. http://doi.org/10.108o/17482798.2012.73978o

Vandoninck, S., d'Haenens, L., \& Segers, K. (2012). Coping and resilience: children's responses to online risks. In S. Livingstone, L. Haddon, \& A. Görzig (Eds.), Children, Risk and Safety on the Internet. Research and policy challenges in comparative perspective (pp. 205-218). Bristol: The Policy Press.

Vaterlaus, J. M., Beckert, T. E., Tulane, S., \& Bird, C. V. (2014). "They always ask what I'm doing and who I'm talking to": parental mediation of adolescent interactive technology use. Marriage $\mathcal{E}$ Family Review, 50(8), 691-713. http://doi.org/10.108o/01494929.2014.938795

Vaughan, P. W., \& Rogers, E. M. (200o). A staged model of communication effects: Evidence from an entertainment-education radio soap opera in Tanzania. Journal of Health Communication, 5(3), 203-227. http://doi.org/10.108o/10810730050131398

Vaughan, P. W., Rogers, E. M., Singhal, A., \& Swalehe, R. M. (2000). Entertainment education and hiv/aids prevention: A field experiment in tanzania. Journal of Health Communication, 5, 81-10o. http://doi.org/10.108o/10810730050019573

Völlink, T., Bolman, C. A. W., Dehue, F., \& Jacobs, N. C. L. (2013). Coping with cyberbullying: Differences between victims, bully-victims and children not involved in bullying. Journal of Community \& Applied Social Psychology, 23(1), 724. http://doi.org/10.1002/casp.2142

Vossen, H. G. M., Piotrowski, J. T., \& Valkenburg, P. M. (2017). The longitudinal relationship between media violence and empathy: Was it sympathy all along? Media Psychology, 2o(2), 175-193. http://doi.org/10.108o/15213269.2015.1121825

Vossen, H. G. M., \& Valkenburg, P. M. (2016). Do social media foster or curtail adolescents' empathy? A longitudinal study. Computers in Human Behavior, 63 , 118-124. http://doi.org/10.1016/j.chb.2016.05.040

Vraga, E., Tully, M., Kotcher, J. E., Smithson, A.-B., \& Broeckelman-Post, M. (2015). A multi-dimensional approach to measuring news media literacy. Journal of Media Literacy Education, 7(3), 41-53. Retrieved from http://digitalcommons.uri.edu/jmle/vol7/iss3/4/

Waasdorp, T. E., \& Bradshaw, C. P. (2015). The overlap between cyberbullying and traditional bullying. Journal of Adolescent Health, 56(5), 483-488. http://doi.org/10.1016/j.jadohealth.2014.12.002 
RISKS OF INTERACTIVE COMMUNICATION IN ADOLESCENTS.

DIGITAL LITERACY DIAGNOSIS AND INTERVENTION

Warren, R. (2001). In words and deeds: Parental involvement and mediation of children's television viewing. Journal of Family Communication, 1(4), 211-231. http://doi.org/10.1207/S15327698JFC0104_01

Watts, L. K., Wagner, J., Velasquez, B., \& Behrens, P. I. (2017). Cyberbullying in higher education: A literature review. Computers in Human Behavior, 69, 268-274. http://doi.org/10.1016/j.chb.2016.12.038

Webb, T., Martin, K., Afifi, A. A., \& Kraus, J. (2010). Media literacy as a violenceprevention strategy: A pilot evaluation. Health Promotion Practice, 11(5), 714-722. http://doi.org/10.1177/1524839908328998

Westby, C. (2010). Multiliteracies: The changing world of communication. Topics in Language Disorders, 30(1), 64-71.

White, T., \& Martin, L. (2014). Mathematics and mobile learning. TechTrends, 58(1), 64-70. http://doi.org/10.1007/978-1-4020-9827-7

Wilkin, H. A., Valente, T. W., Murphy, S., Cody, M. J., Huang, G., \& Beck, V. (2007). Does entertainment-education work with Latinos in the United States? Identification and the effects of a telenovela breast cancer storyline. Journal of Health Communication, $\quad$ 12(5), $455-469$. http://doi.org/10.108o/10810730701438690

Wilkinson, A., Roberts, J., \& While, A. E. (2010). Construction of an instrument to measure student information and communication technology skills, experience and attitudes to e-learning. Computers in Human Behavior, 26(6), 1369-1376. http://doi.org/10.1016/j.chb.2010.04.010

Williams, K., \& Lisi, A. M. G. De. (1999). Coping strategies in adolescents. Journal of Applied Developmental Psychology, 20(4), 537-549. http://doi.org/10.1016/So1933973(99)00025-8

Williford, A., Elledge, L. C., Boulton, A. J., DePaolis, K. J., Little, T. D., \& Salmivalli, C. (2013). Effects of the KiVa antibullying program on cyberbullying and cybervictimization frequency among Finnish youth. Journal of Clinical Child and $\begin{array}{llll}\text { Adolescent } & \text { Psychology, } & \text { 42(6), } & \end{array}$ http://doi.org/10.1080/15374416.2013.787623

Wilson, M., Scalise, K., \& Gochyyev, P. (2015). Rethinking ICT literacy: From computer skills to social network settings. Thinking Skills and Creativity, 18, 65-80. http://doi.org/10.1016/j.tsc.2015.05.001

Woods, S., Hall, L., Dautenhahn, K., \& Wolke, D. (2007). Implications of gender differences for the development of animated characters for the study of bullying behavior. Computers in Human Behavior, 23(1), 770-786. http://doi.org/10.1016/j.chb.2004.11.018 
Wu, Q. (2015). Designing a smartphone app to teach English (L2) vocabulary. $\begin{array}{llll}\text { Computers } \& \text { Education, } & \text { 85, }\end{array}$ http://doi.org/10.1016/j.compedu.2015.02.013

Wu, W.-H., Jim Wu, Y.-C., Chen, C.-Y., Kao, H.-Y., Lin, C.-H., \& Huang, S.-H. (2012). Review of trends from mobile learning studies: A meta-analysis. Computers $\mathcal{E}$ Education, 59(2), 817-827. http://doi.org/10.1016/j.compedu.2012.03.016

Yang, C. C., Tseng, S. S., Liao, A. Y. H., \& Liang, T. (2013). Situated poetry learning using multimedia resource sharing approach. Educational Technology $\mathcal{E}$ Society, 16(2), 282-295.

Ybarra, M. L., Diener-West, M., Markow, D., Leaf, P. J., Hamburger, M., \& Boxer, P. (2008). Linkages between Internet and other media violence with seriously violent behavior by youth. Pediatrics, 122(5), 929-937. http://doi.org/10.1542/peds.2007-3377

Ybarra, M. L., Finkelhor, D., Mitchell, K. J., \& Wolak, J. (2009). Associations between blocking, monitoring, and filtering software on the home computer and youthreported unwanted exposure to sexual material online. Child Abuse and Neglect, 33(12), 857-869. http://doi.org/10.1016/j.chiabu.2008.09.015

Ybarra, M. L., \& Mitchell, K. J. (2014). "Sexting” and its relation to sexual activity and sexual risk behavior in a national survey of adolescents. Journal of Adolescent Health, 55(6), 757-764. http://doi.org/10.1016/j.jadohealth.2014.07.012

Yoo, I.-Y., \& Lee, Y.-M. (2015). The effects of mobile applications in cardiopulmonary assessment education. Nurse Education Today, 35(2), e19-e23. http://doi.org/10.1016/j.nedt.2014.12.002

Youn, S. (2005). Teenagers' perceptions of online privacy and coping behaviors: A riskbenefit appraisal approach. Journal of Broadcasting E Electronic Media., 49(1), 322. http://doi.org/10.1207/s15506878jobem4901

Zakaria, N. A., \& Khalid, F. (2016). The benefits and constraints of the use of information and communication technology (ICT) in teaching mathematics. Creative Education, o7(11), 1537-1544. http://doi.org/10.4236/ce.2016.711158

Zaman, B., Nouwen, M., Vanattenhoven, J., de Ferrerre, E., \& Looy, J. Van. (2016). A qualitative inquiry into the contextualized parental mediation practices of young children's digital media use at home. Journal of Broadcasting E Electronic Media, 6o(1), 1-22. http://doi.org/10.108o/o8838151.2015.1127240

Zhang-Kennedy, L., Abdelaziz, Y., \& Chiasson, S. (2017). Cyberheroes: The design and evaluation of an interactive ebook to educate children about online privacy. International Journal of Child-Computer Interaction, 13, 10-18. http://doi.org/10.1016/j.ijcci.2017.05.001 
RISKS OF INTERACTIVE COMMUNICATION IN ADOLESCENTS.

DIGITAL LITERACY DIAGNOSIS AND INTERVENTION

Zhang, H., \& Zhu, C. (2016). A study of digital media literacy of the 5th and 6th grade primary students in Beijing. The Asia-Pacific Education Researcher, 25(4), 579592. http://doi.org/10.1007/s40299-016-0285-2

Zylka, J., Christoph, G., Kroehne, U., Hartig, J., \& Goldhammer, F. (2015). Moving beyond cognitive elements of ICT literacy: First evidence on the structure of ICT engagement. Computers in Human Behavior, 53, 149-160. http://doi.org/10.1016/j.chb.2015.07.008 
APPENDICES 



\section{Appendix 1.}

\section{List of Participating Schools}





\section{Studies 1 and 2}

Pilot

IES Libertad (Carranque, Toledo)

Survey

1. Colegio Divina Pastora (Arenas de San Pedro, Ávila)

2. Colegio Milagrosa-Las Nieves (Ávila, Ávila)

3. Colegio Claret (Segovia, Segovia)

4. IES San Leonardo (San Leonardo de Yagüe, Soria)

5. Colegio Estudio (Madrid, Madrid)

6. Colegio Santa Isabel (Alba de Tormes, Salamanca)

7. IES Odra-Pisuerga (Melgar de Fernamental, Burgos)

8. IES Pío del Río Hortega (Portillo, Valladolid)

9. Colegio Nuestra Señora de Lourdes (Valladolid, Valladolid)

10. Colegio Divina Pastora (León, León)

11. Colegio Sagrada Familia - Siervas de San José (Salamanca, Salamanca)

12. Colegio Amor de Dios (Toro, Zamora)

13. IES Tierra de Ciudad Rodrigo (Ciudad Rodrigo, Salamanca)

\section{Study 3}

Pilot

Colegio Sagrada Familia - Siervas de San José (Salamanca, Salamanca)

Survey

1. Colegio Nuestra Señora de Lourdes (Valladolid, Valladolid)

2. Colegio Divina Pastora (Arenas de San Pedro, Ávila)

3. IES Pío del Río Hortega (Portillo, Valladolid) 



\title{
Appendix 2.
}

\section{Information Email for School}

\author{
Board
}





\section{Studies 1 and 2}

Estimado/a

Director/a del

A través de este correo nos gustaría solicitar la colaboración de su centro en un estudio acerca de las competencias digitales de los adolescentes. Este estudio, que forma parte de la investigación Riesgos de la Comunicación Interactiva en población adolescente. Diagnóstico e intervención de Alfabetización Digital, financiada por la Junta de Castilla y León y el Fondo Social Europeo (EDU/1083/2013), se está desarrollando en el Observatorio de los Contenidos Audiovisuales (Grupo de Investigación reconocido de la Universidad de Salamanca).

Esta investigación nace ante la preocupación por el uso que hacen los adolescentes de los medios interactivos y los riesgos que pueden encontrar en ellos (exposición a pornografía, acoso cibernético o cyberbullying, acoso sexual o grooming, envío de imágenes o vídeos personales de contenido sexual o sexting, contacto con desconocidos y suplantación de la identidad). A través de esta investigación pretendemos incrementar las competencias digitales de los adolescentes mediante una propuesta de diagnóstico e intervención de alfabetización digital para que puedan hacer frente a estos riesgos. Este proyecto se vertebra en torno a tres estudios complementarios. El primero de ellos, y para el que solicitamos la colaboración, es un estudio de diagnóstico que pretende medir el nivel de competencia digital. El objetivo es conocer el nivel de habilidades que presentan los adolescentes en España. De esta forma, podremos hacer un diagnóstico acerca de las características que debe tener el plan de alfabetización digital.

Para realizar este estudio, el Observatorio de los Contenidos Audiovisuales de la Universidad de Salamanca ha desarrollado un cuestionario que mide el nivel de competencias digitales y el tipo de uso que hacen los menores de los medios interactivos. Estos cuestionarios se distribuirán entre alumnos de Educación Secundaria Obligatoria. Los datos obtenidos se tratarán de manera agregada, por lo 
que queda garantizado el anonimato y la confidencialidad de las respuestas (tanto de los alumnos como del centro educativo). La información únicamente se utilizará para cumplir los objetivos de la investigación.

Por ello, solicitamos la colaboración de su centro de estudio para que sus alumnos de ESO rellenen estos cuestionarios. Esta investigación no requerirá ningún tipo de esfuerzo adicional por parte de los docentes y se limitará a que los alumnos rellenen el cuestionario autocumplimentado. Esta colaboración es de gran utilidad para la realización de este proyecto y para el avance de la investigación y el conocimiento en el ámbito de la alfabetización digital, en particular, y de la comunicación, en general. Asimismo, le garantizamos que toda la información recogida recibirá un tratamiento absolutamente confidencial y, si usted así lo desea, le enviaremos una copia de los resultados del trabajo de investigación una vez éste haya concluido.

Agradeciendo de antemano su colaboración, le saluda atentamente,

Isabel Rodríguez 


\section{Study 3}

Estimado/a Director/a del

Soy Isabel Rodríguez, investigadora de la Universidad de Salamanca. Durante el curso 2015-2016 acudimos a su centro para realizar un estudio acerca de las competencias digitales de los adolescentes. Se trataba de un estudio que forma parte de la investigación Riesgos de la Comunicación Interactiva en población adolescente. Diagnóstico e intervención de Alfabetización Digital, financiada por la Junta de Castilla y León y el Fondo Social Europeo (EDU/1083/2013) y que se está desarrollando en el Observatorio de los Contenidos Audiovisuales (Grupo de Investigación reconocido de la Universidad de Salamanca).

En primer lugar, nos gustaría reiterar nuestro agradecimiento por la colaboración de su centro en la primera fase del estudio, ya que, sin la participación de los centros educativos, hubiera sido imposible recabar toda esa información. A partir de ese primer estudio, hemos desarrollado un programa de intervención de desarrollo de competencias digitales y de estrategias de afrontamiento frente a los riesgos online. Se trata de una aplicación móvil con la que los adolescentes podrán incrementar sus competencias digitales y saber cómo actuar cuando encuentran riesgos al usar medios interactivos (por ejemplo, cuando contactan con desconocidos).

En segundo lugar, nos gustaría solicitar de nuevo la colaboración de su centro para poder implementar esa intervención. Como investigadores, consideramos fundamental comprobar que las intervenciones que se ponen en marcha son realmente eficaces en sus objetivos. El procedimiento para realizar esta fase de la intervención sería el siguiente: 
- Los alumnos rellenan un breve cuestionario (pre-test). Para ello, emplean entre 5 y 10 minutos, como máximo. Con este cuestionario pretendemos conocer su nivel previo, para contrastar cómo de eficaz es la intervención.

- Pasado un mes desde que rellenaron este cuestionario, se desarrolla la intervención. Para ello, desde el grupo de investigación llevaremos los dispositivos móviles con la aplicación instalada, para que los alumnos puedan utilizarla durante una sesión. Al término de la sesión, se pasa un nuevo cuestionario (post-test) con el objetivo de comprobar cómo de eficaz ha sido esa intervención en el desarrollo de competencias digitales y estrategias de afrontamiento frente a riesgos online.

- En este tipo de procesos es necesario contar con dos tipos de grupos de alumnos: un grupo utilizará la aplicación y el otro no, para poder testar que realmente esa aplicación ha sido efectiva (y que los cambios no se deben a otros motivos). Por lo tanto, se requeriría que los alumnos de ambos tipos de grupos rellenasen ambos cuestionarios (pre-test y post-test). Pero solo un tipo de grupo utilizará la aplicación.

Obviamente, al término del proceso, la aplicación móvil quedará totalmente disponible para el centro. De esta forma, podrán ofrecérsela a los alumnos que no la han usado durante la intervención o utilizarla como el centro considere más conveniente.

Por otra parte, esta investigación no requerirá ningún tipo de esfuerzo adicional por parte de los docentes. Asimismo, le garantizamos que toda la información recogida recibirá un tratamiento absolutamente confidencial. Los datos obtenidos se tratarán de manera agregada, por lo que queda garantizado el anonimato y la confidencialidad de las respuestas (tanto de los alumnos como del centro educativo). La información únicamente se utilizará para cumplir los 
objetivos de la investigación. Por otra parte, y si usted así lo desea, además de la aplicación educativa, le enviaremos una copia de los resultados del trabajo de investigación una vez éste haya concluido.

Esta colaboración es de gran utilidad para la realización de este proyecto. Además, consideramos que será muy beneficiosa para los estudiantes de su centro educativo.

Agradeciendo de antemano su colaboración, le saluda atentamente,

Isabel Rodríguez 

Appendix 3.

Consent Form for Parents 



\section{Studies 1 and 2}
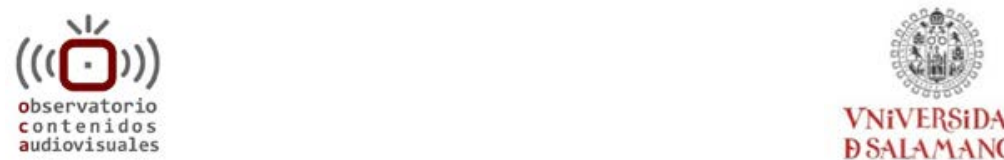

VNiVERSiDAD

contenidos

DSALAMANCA

\section{Consentimiento informado: Participación del alumno en investigación de la Universidad de Salamanca}

El Observatorio de los Contenidos Audiovisuales (Grupo de Investigación Reconocido de la Universidad de Salamanca) está realizando la investigación Riesgos de la Comunicación Interactiva en población adolescente. Diagnóstico e intervención de Alfabetización Digital, financiada por la Junta de Castilla y León y el Fondo Social Europeo (EDU/1083/2013).

Este proyecto nace ante la preocupación por el uso que hacen los adolescentes de los medios interactivos y los riesgos que pueden encontrar en ellos (pornografía, acoso cibernético, acoso sexual, envío de imágenes o vídeos personales de contenido sexual, contacto con desconocidos y suplantación de la identidad). Con esta investigación queremos aumentar las competencias de los menores para que puedan evitar estos riesgos.

Para ello, hemos solicitado la colaboración del (nombre del centro educativo). Por este motivo, los alumnos de Educación Secundaria Obligatoria rellenarán un cuestionario a lo largo del segundo trimestre. Esta actividad, con una duración aproximada de 30 minutos, se realizará en el instituto en horario lectivo.

En ningún momento se pedirá el nombre ni datos identificativos del menor, por lo que garantizamos el anonimato y la confidencialidad de las respuestas. Además, los datos se tratarán de forma global y sólo se utilizarán para los objetivos de la investigación.

La participación en este estudio es voluntaria y puede negarse a que el menor a su cargo participe, sin dar explicaciones y sin ninguna repercusión para usted o para el menor. Si tiene alguna duda o quiere ampliar su información puede ponerse en contacto con la investigadora responsable del proyecto: Isabel Rodríguez de Dios (isabelrd@usal.es).

Agradeciendo de antemano su colaboración, le saluda atentamente,

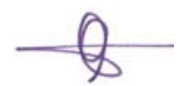

Isabel Rodríguez de Dios

Sí / No autorizo a mi hijo/a o representado/a legal a participar en este estudio. 


\section{Study 3}
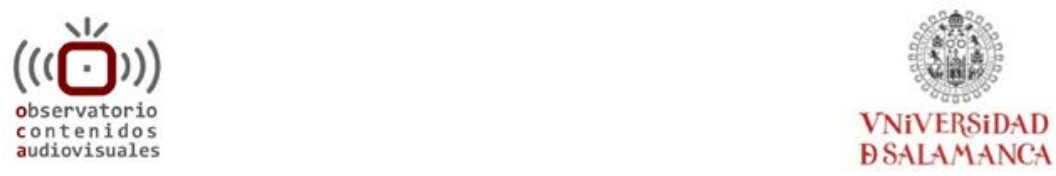

\section{Consentimiento informado: Participación del alumno en investigación de la Universidad de Salamanca}

El Observatorio de los Contenidos Audiovisuales (Grupo de Investigación Reconocido de la Universidad de Salamanca) está realizando la investigación Riesgos de la Comunicación Interactiva en población adolescente. Diagnóstico e intervención de Alfabetización Digital, financiada por la Junta de Castilla y León y el Fondo Social Europeo (EDU/1083/2013).

Este proyecto nace ante la preocupación por el uso que hacen los adolescentes de los medios interactivos y los riesgos que pueden encontrar en ellos (pornografía, acoso cibernético, acoso sexual, envío de imágenes 0 vídeos personales de contenido sexual, contacto con desconocidos y suplantación de la identidad). Con esta investigación queremos aumentar las competencias de los menores para que puedan evitar estos riesgos.

Para ello, hemos solicitado la colaboración del (nombre centro educativo). Por este motivo, algunos alumnos de Educación Secundaria Obligatoria participarán en una intervención educativa y rellenarán un cuestionario a lo largo del segundo trimestre. Esta actividad se realizará en el centro en horario lectivo. En ningún momento se pedirá el nombre ni datos identificativos del menor, por lo que garantizamos el anonimato y la confidencialidad de las respuestas. Además, los datos se tratarán de forma global y sólo se utilizarán para los objetivos de la investigación.

La participación en este estudio es voluntaria y puede negarse a que el menor a su cargo participe, sin dar explicaciones y sin ninguna repercusión para usted o para el menor. Si tiene alguna duda o quiere ampliar su información puede ponerse en contacto con la investigadora responsable del proyecto: Isabel Rodríguez de Dios (isabelrd@usal.es).

Agradeciendo de antemano su colaboración, le saluda atentamente,

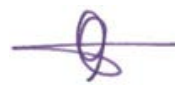

Isabel Rodríguez de Dios

Sí / No autorizo a mi hijo/a o representado/a legal

a participar en este estudio. 


\section{Appendix 4.}

Survey: Questionnaire 



\section{ESTUDIO SOBRE TECNOLOGÍAS DIGITALES}

El Observatorio de los Contenidos Audiovisuales de la Universidad de Salamanca está desarrollando una investigación sobre el uso de las tecnologías digitales.

El cuestionario que te presentamos tiene varias preguntas relacionadas con diferentes aspectos del uso de las tecnologías. Te rogamos que contestes a todas las preguntas que aparecen en el cuestionario. No existen respuestas correctas o incorrectas, todas son válidas. Lo interesante para nosotros es conocer tu opinión sincera.

La información solo se utilizará con fines científicos. Los datos serán procesados estadísticamente de manera colectiva y agregada, por lo que está garantizado totalmente el anonimato y el carácter confidencial de tus respuestas al cuestionario.

\section{MUCHAS GRACIAS POR TU COLABORACIÓN}

1. Para empezar, marca con una $\mathrm{X}$ aquellos dispositivos o tecnologías, que haya en tu casa.

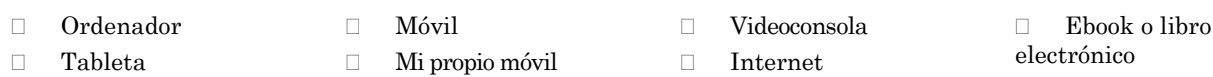

2. Ahora nos gustaría saber con qué frecuencia utilizas los siguientes dispositivos.

\begin{tabular}{lccccc}
\hline & $\begin{array}{c}\text { Varias } \\
\text { veces al día }\end{array}$ & $\begin{array}{c}\text { Una vez al } \\
\text { día }\end{array}$ & $\begin{array}{c}\text { Dos o tres } \\
\text { veces a la } \\
\text { semana }\end{array}$ & $\begin{array}{c}\text { Con menos } \\
\text { frecuencia }\end{array}$ & Nunca \\
\hline - Ordenador & 1 & 2 & 3 & 4 & 5 \\
\hline - Tableta & 1 & 2 & 3 & 4 & 5 \\
\hline - Móvil & 1 & 2 & 3 & 4 & 5 \\
\hline - Videoconsola & 1 & 2 & 3 & 4 & 5 \\
\hline
\end{tabular}


RISKS OF INTERACTIVE COMMUNICATION IN ADOLESCENTS. DIGITAL LITERACY DIAGNOSIS AND INTERVENTION

3. ¿Y con qué frecuencia usas estas herramientas o haces las siguientes actividades?

\begin{tabular}{lccccc}
\hline & $\begin{array}{c}\text { Varias } \\
\text { veces al } \\
\text { día }\end{array}$ & $\begin{array}{c}\text { Una vez } \\
\text { al día }\end{array}$ & $\begin{array}{c}\text { Dosotres } \\
\text { vecesala } \\
\text { semana }\end{array}$ & $\begin{array}{c}\text { Con menos } \\
\text { frecuencia }\end{array}$ & Nunca \\
\hline - Internet & 1 & 2 & 3 & 4 & 5 \\
\hline - Correo electrónico & 1 & 2 & 3 & 4 & 5 \\
\hline - Redes sociales (ej. Facebook, Twitter...) & 1 & 2 & 3 & 4 & 5 \\
\hline - Mensajería instantánea (ej. WhatsApp) & 1 & 2 & 3 & 4 & 5 \\
\hline - Aplicaciones para jugar en móvil o tableta & 1 & 2 & 3 & 4 & 5 \\
\hline - Juegos (ordenador o videoconsola) & 1 & 2 & 3 & 4 & 5 \\
\hline - Jugar con otras personas en línea & 1 & 2 & 3 & 4 & 5 \\
\hline - Descarga de aplicaciones para móvil o tableta & 1 & 2 & 3 & 4 & 5 \\
\hline - Descarga de películas o música & 1 & 2 & 3 & 4 & 5 \\
\hline - Videollamadas (ej. Skype) & 1 & 2 & 3 & 4 & 5 \\
\hline - Software para editar fotos o vídeos (ej. Photoshop) & 1 & 2 & 3 & 4 & 5 \\
\hline
\end{tabular}

4. ¿Con qué frecuencia accedes a Internet desde los siguientes lugares?

\begin{tabular}{lccccc}
\hline & $\begin{array}{c}\text { Varias } \\
\text { veces al } \\
\text { día }\end{array}$ & $\begin{array}{c}\text { Una } \\
\text { vez al } \\
\text { día }\end{array}$ & $\begin{array}{c}\text { Dosotres } \\
\text { veces ala } \\
\text { semana }\end{array}$ & $\begin{array}{c}\text { Con menos } \\
\text { frecuencia }\end{array}$ & $\begin{array}{c}\text { Nunca } \\
\text { - Tu propia habitación }\end{array}$ \\
\hline - Otros lugares de la casa & 1 & 2 & 3 & 4 & 5 \\
\hline - Tu centro educativo & 1 & 2 & 3 & 4 & 5 \\
\hline - De camino al instituto, a casa... & 1 & 2 & 3 & 4 & 5 \\
\hline
\end{tabular}

5. A continuación, se presentan una serie de afirmaciones relacionadas con tu uso de la tecnología. En la escala, cada número muestra un nivel de acuerdo con la frase, lee atentamente cada una de las afirmaciones y marca la opción que mejor te defina.

\begin{tabular}{|c|c|c|c|c|c|}
\hline & $\begin{array}{l}\text { Totalmente } \\
\text { desacuerdo }\end{array}$ & Desacuerdo & $\begin{array}{l}\text { Ni de acuerdo } \\
\text { ni desacuerdo }\end{array}$ & $\begin{array}{c}\text { De } \\
\text { acuerdo }\end{array}$ & $\begin{array}{l}\text { Totalmente } \\
\text { de acuerdo }\end{array}$ \\
\hline $\begin{array}{l}\text { - Si me gusta alguna foto que encuentre online, siempre } \\
\text { se cómo guardarla en mi ordenador }\end{array}$ & 1 & 2 & 3 & 4 & 5 \\
\hline $\begin{array}{l}\text { - Siempre sé conectarme a una red WIFI, da igual el lugar } \\
\text { en el que me encuentre o el dispositivo que esté usando }\end{array}$ & 1 & 2 & 3 & 4 & 5 \\
\hline $\begin{array}{l}\text { - Si encuentro una página que me gusta, sé cómo } \\
\text { guardarla para poder volver a verla después }\end{array}$ & 1 & 2 & 3 & 4 & 5 \\
\hline $\begin{array}{l}\text { - Sé utilizar atajos de teclado (ej. CTRL+C o cmd+C para } \\
\text { copiar) }\end{array}$ & 1 & 2 & 3 & 4 & 5 \\
\hline $\begin{array}{l}\text { - Si algo no funciona cuando estoy usando algún dispositivo } \\
\text { digital (ordenador, móvil...), normalmente sé lo que es y cómo } \\
\text { arreglarlo }\end{array}$ & 1 & 2 & 3 & 4 & 5 \\
\hline $\begin{array}{l}\text { - Si quiero instalar un programa en mi ordenador, tendría que } \\
\text { pedir a alguien que lo haga por mí, porque no sé hacerlo }\end{array}$ & 1 & 2 & 3 & 4 & 5 \\
\hline $\begin{array}{l}\text { - No me gusta descargarme aplicaciones nuevas porque } \\
\text { me cuesta aprender a usarlas }\end{array}$ & 1 & 2 & 3 & 4 & 5 \\
\hline - Me resulta fácil aprender a usar un nuevo móvil, ordenador... & 1 & 2 & 3 & 4 & 5 \\
\hline
\end{tabular}


6. Ahora muestra tu nivel acuerdo con estos enunciados sobre la búsqueda de información:

\begin{tabular}{|c|c|c|c|c|c|}
\hline & $\begin{array}{l}\text { Totalmente } \\
\text { desacuerdo }\end{array}$ & Desacuerdo & $\begin{array}{l}\text { Ni de acuerdo } \\
\text { ni desacuerdo }\end{array}$ & $\begin{array}{c}\text { De } \\
\text { acuerdo }\end{array}$ & $\begin{array}{l}\text { Totalmente } \\
\text { de acuerdo }\end{array}$ \\
\hline $\begin{array}{l}\text {-Me parece difícil encontrar cuáles son las mejores palabras } \\
\text { que tengo que usar cuando utilizo un buscador }\end{array}$ & 1 & 2 & 3 & 4 & 5 \\
\hline -Me canso cuando tengo que buscar información online & 1 & 2 & 3 & 4 & 5 \\
\hline $\begin{array}{l}\text {-A veces acabo en páginas web sin saber cómo he llegado } \\
\text { a ellas }\end{array}$ & 1 & 2 & 3 & 4 & 5 \\
\hline $\begin{array}{l}\text {-Me parece que la manera en que están organizadas la } \\
\text { mayoría de las páginas web es confusa }\end{array}$ & 1 & 2 & 3 & 4 & 5 \\
\hline $\begin{array}{l}\text {-A veces me cuesta comprobar si la información que he } \\
\text { obtenido es útil para mi trabajo }\end{array}$ & 1 & 2 & 3 & 4 & 5 \\
\hline $\begin{array}{l}\text {-El ordenador me resulta útil para organizar la } \\
\text { información que encuentro }\end{array}$ & 1 & 2 & 3 & 4 & 5 \\
\hline $\begin{array}{l}\text {-Considero importante saber quién ha escrito la } \\
\text { información que estoy utilizando }\end{array}$ & 1 & 2 & 3 & 4 & 5 \\
\hline $\begin{array}{l}\text {-Si encuentro información en una página web, dejo de } \\
\text { buscar. No hace falta comparar con otras páginas para } \\
\text { ver si es la información es buena }\end{array}$ & 1 & 2 & 3 & 4 & 5 \\
\hline $\begin{array}{l}\text {-Sé descargarme u obtener la información que encuentro } \\
\text { online }\end{array}$ & 1 & 2 & 3 & 4 & 5 \\
\hline
\end{tabular}

7. Muestra tu nivel de acuerdo con el uso que haces de las redes sociales y las tecnologías:

\begin{tabular}{|c|c|c|c|c|c|}
\hline & $\begin{array}{l}\text { Totalmente } \\
\text { desacuerdo }\end{array}$ & Desacuerdo & $\begin{array}{l}\text { Ni de acuerdo } \\
\text { ni desacuerdo }\end{array}$ & $\begin{array}{l}\text { De } \\
\text { acuerdo }\end{array}$ & $\begin{array}{l}\text { Totalmente } \\
\text { de acuerdo }\end{array}$ \\
\hline ¿Sé enviar cualquier tipo de archivo de un móvil a un contacto & 1 & 2 & 3 & 4 & 5 \\
\hline $\begin{array}{l}\text {-Da igual con quien me comunique: siempre es útil usar } \\
\text { emoticonos }\end{array}$ & 1 & 2 & 3 & 4 & 5 \\
\hline $\begin{array}{l}\text {-Creo que en función de con quien quiera comunicarme } \\
\text { es mejor utilizar un método u otro (llamar por teléfono, } \\
\text { mandar un WhatsApp, escribir un email...) }\end{array}$ & 1 & 2 & 3 & 4 & 5 \\
\hline $\begin{array}{l}\text { - Sé configurar cualquiera de mis redes sociales para } \\
\text { elegir con quién compartir mi información (amigos, } \\
\text { amigos de mis amigos, todo el mundo) }\end{array}$ & 1 & 2 & 3 & 4 & 5 \\
\hline $\begin{array}{l}\text { - Sé utilizar las herramientas para reportar un abuso (ej. } \\
\text { suben una foto sin mi permiso) en las redes sociales }\end{array}$ & 1 & 2 & 3 & 4 & 5 \\
\hline $\begin{array}{l}\text { - Sé desactivar la opción de mostrar mi posición } \\
\text { geográfica (ej. En Facebook, aplicaciones de móvil...) }\end{array}$ & 1 & 2 & 3 & 4 & 5 \\
\hline $\begin{array}{l}\text { - Tengo la misma contraseña para todos los dispositivos, } \\
\text { redes sociales... así es más fácil y no se me olvida }\end{array}$ & 1 & 2 & 3 & 4 & 5 \\
\hline -Sé identificar si mi dispositivo tiene un virus informático & 1 & 2 & 3 & 4 & 5 \\
\hline - Uso programas para encontrar y eliminar virus informáticos & 1 & 2 & 3 & 4 & 5 \\
\hline $\begin{array}{l}\text { - Sé configurar mi correo electrónico para bloquear } \\
\text { correo basura }\end{array}$ & 1 & 2 & 3 & 4 & 5 \\
\hline $\begin{array}{l}\text { - Sé cuándo puedo compartir imágenes y vídeos en los } \\
\text { que aparezcan otras personas }\end{array}$ & 1 & 2 & 3 & 4 & 5 \\
\hline $\begin{array}{l}\text { - Conozco las leyes y las consecuencias de descargar y } \\
\text { piratear música y películas }\end{array}$ & 1 & 2 & 3 & 4 & 5 \\
\hline
\end{tabular}


8. De nuevo, muestra tu nivel de acuerdo con los siguientes enunciados:

\begin{tabular}{|c|c|c|c|c|c|}
\hline & $\begin{array}{l}\text { Totalmente } \\
\text { desacuerdo }\end{array}$ & Desacuerdo & $\begin{array}{l}\text { Ni de acuerdo } \\
\text { ni desacuerdo }\end{array}$ & $\begin{array}{c}\text { De } \\
\text { acuerdo }\end{array}$ & $\begin{array}{l}\text { Totalmente } \\
\text { de acuerdo }\end{array}$ \\
\hline $\begin{array}{l}\text { - Sé identificar si la información que encuentro en una } \\
\text { web es verdadera o falsa. }\end{array}$ & 1 & 2 & 3 & 4 & 5 \\
\hline $\begin{array}{l}\text { - Se buscar el autor de una información y evaluar si es } \\
\text { una persona creíble o no }\end{array}$ & 1 & 2 & 3 & 4 & 5 \\
\hline $\begin{array}{l}\text { - Sé comparar diferentes fuentes de información para } \\
\text { decidir si una información es verdadera }\end{array}$ & 1 & 2 & 3 & 4 & 5 \\
\hline $\begin{array}{l}\text { - Sé comparar diferentes aplicaciones para utilizar la que } \\
\text { sea más fiable y segura }\end{array}$ & 1 & 2 & 3 & 4 & 5 \\
\hline $\begin{array}{l}\text { - Cuando hablo con una persona que he conocido de } \\
\text { forma online, sé comprobar si su identidad es real }\end{array}$ & 1 & 2 & 3 & 4 & 5 \\
\hline - Creo que la información que hay en la red es real y fiable & 1 & 2 & 3 & 4 & 5 \\
\hline
\end{tabular}

9. A continuación, se presentan una serie de afirmaciones relacionadas con tu actitud hacia la tecnología. Señala en qué medida estás de acuerdo con cada una de ellas:

\begin{tabular}{|c|c|c|c|c|c|}
\hline & $\begin{array}{l}\text { Totalmente } \\
\text { desacuerdo }\end{array}$ & Desacuerdo & $\begin{array}{l}\text { Ni de acuerdo } \\
\text { ni desacuerdo }\end{array}$ & $\begin{array}{l}\text { De } \\
\text { acuerdo }\end{array}$ & $\begin{array}{l}\text { Totalmente } \\
\text { de acuerdo }\end{array}$ \\
\hline - Para mí es muy importante poder estudiar con el ordenador & 1 & 2 & 3 & 4 & 5 \\
\hline - Me lo paso bien cuando uso Internet para buscar información & 1 & 2 & 3 & 4 & 5 \\
\hline - Cuando tengo que usar el ordenador me pongo tenso & 1 & 2 & 3 & 4 & 5 \\
\hline - Es más divertido hacer los deberes con el ordenador que sin él & 1 & 2 & 3 & 4 & 5 \\
\hline $\begin{array}{l}\text { - Si tengo que hacer los deberes con el ordenador me } \\
\text { pongo nervioso }\end{array}$ & 1 & 2 & 3 & 4 & 5 \\
\hline $\begin{array}{l}\text { - Usar tecnologías digitales (ordenador, Internet, } \\
\text { tableta...) hace que aprender cosas sea más divertido }\end{array}$ & 1 & 2 & 3 & 4 & 5 \\
\hline $\begin{array}{l}\text { - Los profesores deberían usar más tecnologías digitales } \\
\text { en clase }\end{array}$ & 1 & 2 & 3 & 4 & 5 \\
\hline - Los ordenadores me hacen sentir incómodo e inseguro & 1 & 2 & 3 & 4 & 5 \\
\hline - Uso el ordenador porque me interesa la tecnología & 1 & 2 & 3 & 4 & 5 \\
\hline - Me gusta aprender a hacer cosas nuevas con el ordenador & 1 & 2 & 3 & 4 & 5 \\
\hline - Me parece divertido usar el ordenador & 1 & 2 & 3 & 4 & 5 \\
\hline - Uso el ordenador siempre que puedo & 1 & 2 & 3 & 4 & 5 \\
\hline - Uso el móvil siempre que puedo & 1 & 2 & 3 & 4 & 5 \\
\hline - Intento evitar usar el ordenador porque no lo entiendo bien & 1 & 2 & 3 & 4 & 5 \\
\hline - Me interesa la información sobre los últimos móviles & 1 & 2 & 3 & 4 & 5 \\
\hline - Cuando tengo que usar Internet estoy a disgusto & 1 & 2 & 3 & 4 & 5 \\
\hline - Me siento nervioso si tengo que usar el móvil & 1 & 2 & 3 & 4 & 5 \\
\hline $\begin{array}{l}\text { - Tengo miedo de usar el ordenador por si cometo errores } \\
\text { que no se arreglar }\end{array}$ & 1 & 2 & 3 & 4 & 5 \\
\hline $\begin{array}{l}\text { - Cuando me sale un mensaje de error en el ordenador me } \\
\text { pongo nervioso }\end{array}$ & 1 & 2 & 3 & 4 & 5 \\
\hline $\begin{array}{l}\text { - Me preocupa hacer algo mal en el móvil y borrar } \\
\text { información sin querer }\end{array}$ & 1 & 2 & 3 & 4 & 5 \\
\hline
\end{tabular}


10. Cuando utilizamos Internet y las redes sociales, podemos hacer muchas cosas. Indica con qué frecuencia realizas las siguientes:

\begin{tabular}{|c|c|c|c|c|c|}
\hline & Nunca & $\begin{array}{l}\text { Pocas } \\
\text { veces }\end{array}$ & $\begin{array}{l}\text { Algunas } \\
\text { veces }\end{array}$ & $\begin{array}{l}\text { Bastantes } \\
\text { veces }\end{array}$ & Siempre \\
\hline $\begin{array}{l}\text { - Doy datos personales (dirección, teléfono...) a personas } \\
\text { que no conozco en la vida real }\end{array}$ & 1 & 2 & 3 & 4 & 5 \\
\hline $\begin{array}{l}\text { - Chateo o hablo con personas que he conocido online } \\
\text { y no cara a cara }\end{array}$ & 1 & 2 & 3 & 4 & 5 \\
\hline $\begin{array}{l}\text { - Mando fotos mías a alguien que no conozco en la } \\
\text { vida real }\end{array}$ & 1 & 2 & 3 & 4 & 5 \\
\hline $\begin{array}{l}\text { - Quedo en persona con alguien que he conocido } \\
\text { online }\end{array}$ & 1 & 2 & 3 & 4 & 5 \\
\hline $\begin{array}{l}\text { - Agrego a personas que no conozco en la realidad a } \\
\text { mis redes sociales }\end{array}$ & 1 & 2 & 3 & 4 & 5 \\
\hline $\begin{array}{l}\text { - Alguien se ha hecho pasar por mí en Internet para } \\
\text { publicar cosas como si fuese yo para hacerme daño }\end{array}$ & 1 & 2 & 3 & 4 & 5 \\
\hline $\begin{array}{l}\text { - Han colgado en Internet fotos o vídeos míos para } \\
\text { hacerme daño o reírse de mí }\end{array}$ & 1 & 2 & 3 & 4 & 5 \\
\hline $\begin{array}{l}\text { - Se han burlado de mí con comentarios ofensivos o } \\
\text { insultantes en redes sociales }\end{array}$ & 1 & 2 & 3 & 4 & 5 \\
\hline $\begin{array}{l}\text { - Recibo insultos o amenazas en el móvil o en redes } \\
\text { sociales }\end{array}$ & 1 & 2 & 3 & 4 & 5 \\
\hline $\begin{array}{l}\text { - Recibo en el móvil, correo... videos o imágenes } \\
\text { pornográficas }\end{array}$ & 1 & 2 & 3 & 4 & 5 \\
\hline $\begin{array}{l}\text { - Envío fotos mías en las que estoy desnudo o muestro } \\
\text { partes íntimas de mi cuerpo por el móvil o por } \\
\text { Internet }\end{array}$ & 1 & 2 & 3 & 4 & 5 \\
\hline $\begin{array}{l}\text { - Recibo fotos de personas que conozco (online o en la vida } \\
\text { real) que están desnudas o muestran partes íntimas de su } \\
\text { cuerpo }\end{array}$ & 1 & 2 & 3 & 4 & 5 \\
\hline $\begin{array}{l}\text { - Acabo sin querer en webs pornográficas cuando uso } \\
\text { Internet }\end{array}$ & 1 & 2 & 3 & 4 & 5 \\
\hline $\begin{array}{l}\text { - Acabo sin querer en webs con contenidos violentos o } \\
\text { desagradables }\end{array}$ & 1 & 2 & 3 & 4 & 5 \\
\hline $\begin{array}{l}\text { - Entro intencionadamente en páginas web } \\
\text { pornográficas }\end{array}$ & 1 & 2 & 3 & 4 & 5 \\
\hline $\begin{array}{l}\text { - Entro intencionadamente en páginas web con } \\
\text { contenidos violentos o desagradables }\end{array}$ & 1 & 2 & 3 & 4 & 5 \\
\hline $\begin{array}{l}\text { - Publico comentarios ofensivos en las redes sociales } \\
\text { para reírme de alguien o hacerle daño }\end{array}$ & 1 & 2 & 3 & 4 & 5 \\
\hline $\begin{array}{l}\text { - Cuelgo fotos o vídeos de otras personas para hacerles } \\
\text { daño o reírme de ellos }\end{array}$ & 1 & 2 & 3 & 4 & 5 \\
\hline
\end{tabular}


11. Ahora piensa en tus padres o tutores, ¿con qué frecuencia suelen...?

\begin{tabular}{|c|c|c|c|c|c|}
\hline & Nunca & $\begin{array}{l}\text { Pocas } \\
\text { veces }\end{array}$ & $\begin{array}{c}\text { Algunas } \\
\text { veces }\end{array}$ & $\begin{array}{c}\text { Bastantes } \\
\text { veces }\end{array}$ & Siempre \\
\hline - Bloquear o prohibirte visitar ciertas páginas web & 1 & 2 & 3 & 4 & 5 \\
\hline $\begin{array}{l}\text { - Limitar el tiempo que puedes estar online (en el } \\
\text { ordenador, en el móvil...) }\end{array}$ & 1 & 2 & 3 & 4 & 5 \\
\hline $\begin{array}{l}\text { - Rastrear o vigilar lo que haces en línea, por ejemplo, } \\
\text { revisando tu historial de Internet }\end{array}$ & 1 & 2 & 3 & 4 & 5 \\
\hline - Revisar tus conversaciones en WhatsApp, Facebook... & 1 & 2 & 3 & 4 & 5 \\
\hline $\begin{array}{l}\text { - Revisar la lista de contactos o amigos que tienes en el } \\
\text { móvil o en las redes sociales }\end{array}$ & 1 & 2 & 3 & 4 & 5 \\
\hline - Ayudarte cuando te cuesta encontrar algo en Internet & 1 & 2 & 3 & 4 & 5 \\
\hline $\begin{array}{l}\text { - Explicarte por qué algunas páginas web son buenas } \\
\text { o malas }\end{array}$ & 1 & 2 & 3 & 4 & 5 \\
\hline $\begin{array}{l}\text { - Hablar contigo sobre los beneficios y los peligros que } \\
\text { tiene usar Internet, el móvil... }\end{array}$ & 1 & 2 & 3 & 4 & 5 \\
\hline $\begin{array}{l}\text { - Sugerirte formas de usar los dispositivos digitales de } \\
\text { una forma segura }\end{array}$ & 1 & 2 & 3 & 4 & 5 \\
\hline $\begin{array}{l}\text { - Sugerirte formas de actuar con otras personas } \\
\text { cuando estás online }\end{array}$ & 1 & 2 & 3 & 4 & 5 \\
\hline $\begin{array}{l}\text { - Ayudarte cuando algo te molesta en Internet, en el } \\
\text { móvil... }\end{array}$ & 1 & 2 & 3 & 4 & 5 \\
\hline $\begin{array}{l}\text { - Han hablado contigo sobre qué podrías hacer si algo te } \\
\text { molesta en Internet, en el móvil... }\end{array}$ & 1 & 2 & 3 & 4 & 5 \\
\hline
\end{tabular}

12. Pensando de nuevo en tus padres (o tutores), nos gustaría que nos indicases cuál es el nivel educativo más alto que han alcanzado.

Nivel de estudios de un tutor, padre o madre: Sin estudios o primarios incompletos Estudios primarios o secundarios obligatorios (ESO)

$\square \quad$ Estudios postobligatorios no universitarios (Bachillerato o Formación Profesional)

$\square \quad$ Estudios universitarios
Nivel de estudios del otro tutor, padre o madre: Sin estudios o primarios incompletos Estudios primarios o secundarios obligatorios (ESO)

Estudios postobligatorios no universitarios (Bachillerato o Formación Profesional)

Estudios universitarios

Mi familia es monoparental (solo tengo un padre o madre). 


\begin{tabular}{llll}
\hline DATOS SOCIODEMOGRÁFICOS & \\
\hline SEXO: & EDAD: & & \\
& $1-\quad$ Hombre & CURSO: \\
& & $\square 1^{\circ} \mathrm{ESO} \square 3^{\circ} \mathrm{ESO}$ \\
& & Mujer & $\square 2^{\circ} \mathrm{ESO} \square 4^{\circ} \mathrm{ESO}$
\end{tabular}


RISKS OF INTERACTIVE COMMUNICATION IN ADOLESCENTS.

DIGITAL LITERACY DIAGNOSIS AND INTERVENTION

No de Cuestionario:

\begin{tabular}{|c|}
\hline ESTUDIO SOBRE \\
TECNOLOGÍAS DIGITALES \\
\hline
\end{tabular}

El Observatorio de los Contenidos Audiovisuales de la Universidad de Salamanca esta desarrollando una investización sobre el uso de las tecnologías digitales.

El cuestionario que te presentamos tiene varias preguntas relacionadas con diferestes

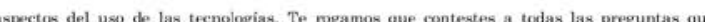

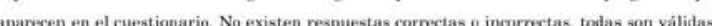
Linteresante para nosotros es conceer tu opinión sincera.

La información sólo se utilizará con fines científicos. Los datos serán procesade

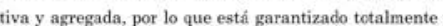
nonimato y el carácter confidencial de tus respuestas a euestionarie

MUCHAS GRACIAS POR TU COLABORACIÓN

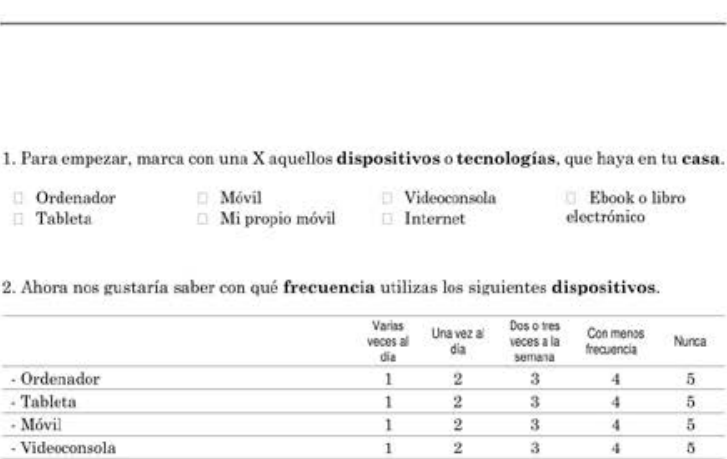

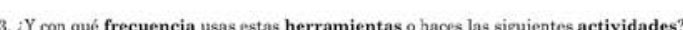

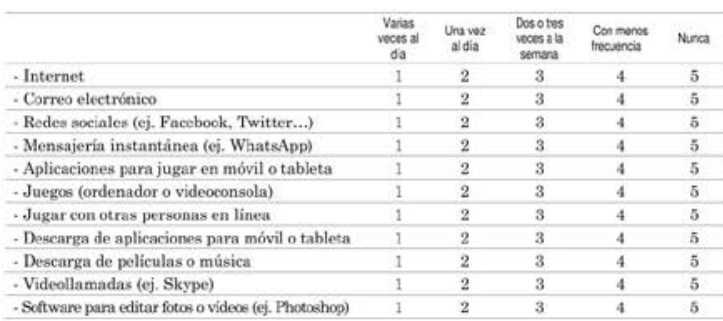

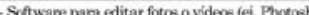

4. ¿Con qué frecuencia accedes a Internet desde los siguientes lugares?

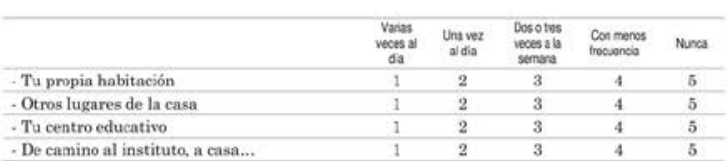

5. A continuación, se presentan una serie de afirmaciones relacionadas con tu uso de la cenologia. En la eecela, cada número muestra un nivel de acuerdo con la frase, lec
atentamente adada una de las afirmaciones $y$ marra la opción que mejor te defina.

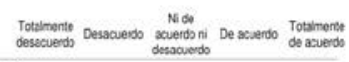

\begin{tabular}{|c|c|c|c|c|c|}
\hline $\begin{array}{l}\text { Si me gusta alpuna foto que encuentre enline, siempre } \\
\text { e commo guardarla en mi ordenador }\end{array}$ & 1 & 2 & 3 & 4 & 5 \\
\hline $\begin{array}{l}\text { Siempre séc conectarme a una red WIF, da igual el } \\
\text { luguar en el que me encuentre o ol dispositivo que esté } \\
\text { usando }\end{array}$ & 1 & 2 & 3 & 4 & 5 \\
\hline $\begin{array}{l}\text { Si encuentro una pigina que me gusta, sé cimo } \\
\text { guardaria para poder volver a verla después }\end{array}$ & 1 & 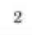 & 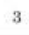 & 4 & 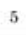 \\
\hline $\begin{array}{l}\text { Séutilizar atajos de teclado (j. CTRL }+\mathrm{Co} \text { omd }+\mathrm{C} \text { para } \\
\text { copiarr) }\end{array}$ & 1 & $2^{2}$ & $3^{3}$ & 4 & 5 \\
\hline 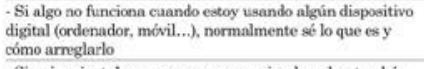 & 1 & 2 & 3 & 4 & 5 \\
\hline 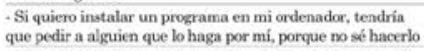 & 1 & 2 & 3 & 4 & 5 \\
\hline $\begin{array}{l}\text { No me gusta descaragame aplicaciones nuevas porque } \\
\text { c cuestia uprendier a usarlas }\end{array}$ & 1 & 2 & 3 & 4 & 5 \\
\hline - Me resulten fícil apre & & & & & \\
\hline
\end{tabular}


G. Ahora muestra tu nivel acuerdo con estos enunciados sobre la búsqueda de información

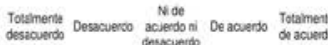

\begin{tabular}{|c|c|c|c|c|c|}
\hline & & & & & \\
\hline 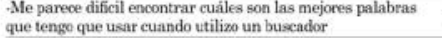 & & ${ }^{2}$ & 3 & & \\
\hline Me canso cuando tengo que buxar informacín onlino & 1 & 2 & 3 & 4 & \\
\hline $\begin{array}{l}\text { Aveces acaloo en pigininas web sin saber como he llegado } \\
\text { a llas }\end{array}$ & 1 & 2 & 3 & 4 & 5 \\
\hline $\begin{array}{l}\text { Me parreco que la manera en que eftán organizadas ha } \\
\text { mayoria de las paiginas web es confusa }\end{array}$ & 1 & 2 & 3 & 4 & 5 \\
\hline $\begin{array}{l}\text { A veces me cuesta comprobaras si lin información que he } \\
\text { obtenido es útil para mi trabajo }\end{array}$ & 1 & 2 & 3 & 4 & 5 \\
\hline $\begin{array}{l}\text { El ordenador me resulta titil para organizar lat } \\
\text { información que encuuntro }\end{array}$ & 1 & 2 & 3 & 4 & 5 \\
\hline $\begin{array}{l}\text { Considero importante saber quiéé ha escrito la } \\
\text { información que estoy utilizando }\end{array}$ & 1 & 2 & 3 & & \\
\hline 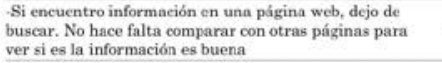 & & 2 & 3 & & 5 \\
\hline descargarme u obtener la inf & & & & & \\
\hline
\end{tabular}

7. Muestra tu nivel de acuerdo con el uso que haces de las redes sociales $y$ las tecnologias

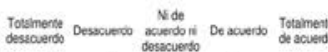

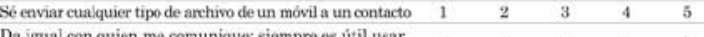
$\begin{array}{lllllll}\text {-Da igual con quien me comunique: siempre es útili usar } & 1 & 2 & 3 & 4 & 5\end{array}$

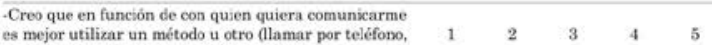
degir con quién compartir mi información (amiges $\begin{array}{lllll}1 & 2 & 3 & 4 & 5\end{array}$ \begin{tabular}{llllll} 
Sé utilizar las herramientas para reportar un abuso & & & & & \\
\hline
\end{tabular} $\begin{array}{lllllll}\text { Sé desactivar la opción de mostrar mi posición } & 1 & 2 & 3 & 4 & 5\end{array}$ $\begin{array}{lllllll}\text { Tengo la misma contraseña para todos los dispositivos, } & 1 & 2 & 3 & 4 & 5\end{array}$ Uso proveramas para enonotrar y eliminat virus Sé confifurar mi correo electrónico para bloquer Séc cuándo puedo compartir imágenes $\mathrm{y}$ videos en los que aparezcan otra Conozoc las leyes y las con

$\begin{array}{lllll}1 & 2 & 3 & 4 & 5 \\ 1 & 2 & 3 & 4 & 5 \\ 1 & 2 & 3 & 4 & 5\end{array}$

8. De nuevo, muestra tu nivel de acuerdo con los siguientes anunciados:

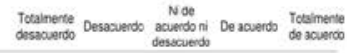

\begin{tabular}{|c|c|c|c|c|c|}
\hline & & & & & \\
\hline $\begin{array}{l}\text {-Sé identificar si la información que encuentro en una } \\
\text { web es verdadera o falka. }\end{array}$ & 1 & 2 & 3 & 4 & 5 \\
\hline $\begin{array}{l}\text { Se buscar el autor do una informací́n y evaluar si ee } \\
\text { una persona creible oo }\end{array}$ & 1 & 2 & 3 & 4 & 5 \\
\hline $\begin{array}{l}\text { Sec comparar diferentes fuentes de información para } \\
\text { decidir si una información es verdadera }\end{array}$ & 1 & 2 & 3 & s & 5 \\
\hline $\begin{array}{l}\text {-Sé émparar diferentes aplicaciones para utilizar la } \\
\text { que sea mis fabley seegura }\end{array}$ & 1 & 2 & 3 & t & 5 \\
\hline $\begin{array}{l}\text { Cuando habbo con una persona que he conocido de de } \\
\text { forma online, sé comprobar si su identidad es real }\end{array}$ & 1 & 2 & 3 & s & 5 \\
\hline 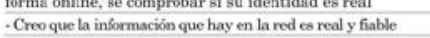 & 1 & 2 & 3 & & 5 \\
\hline
\end{tabular}

9. A continuación, se prosentan una serio do afirmaciones relacionadas con tu actitud hace

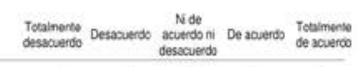

\begin{tabular}{|c|c|c|c|c|c|}
\hline & & & & & \\
\hline $\begin{array}{l}\text { Parn mi es muy importante podere estudiar con el } \\
\text { denanador }\end{array}$ & 1 & 2 & 3 & 4 & 5 \\
\hline $\begin{array}{l}\text { - Me lo paso bien cuando uso Intermet para buscar } \\
\text { ifforpacín }\end{array}$ & 1 & 2 & 3 & 4 & 5 \\
\hline $\begin{array}{l}\text { nomancion } \\
\text { Cundo tengo que usar el ordenador me pongo tenso }\end{array}$ & 1 & 2 & 3 & 4 & \\
\hline $\begin{array}{l}\text { - Es más divertido hacer los deberess cone el ordenador que } \\
\text { s na d }\end{array}$ & 1 & 2 & 3 & 4 & 5 \\
\hline $\begin{array}{l}\text { Si tengo que hacer los deberes con el ordenador me } \\
\text { pingon nevionos }\end{array}$ & 1 & 2 & 3 & 4 & 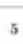 \\
\hline 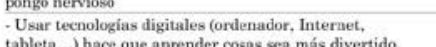 & 1 & 2 & 3 & 4 & 5 \\
\hline 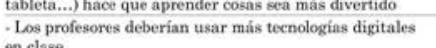 & 1 & 2 & 3 & 4 & 5 \\
\hline $\begin{array}{l}\text { en elase } \\
\text { - Los ordenadores me haven sentiti inớmodo e inseguro }\end{array}$ & 1 & 2 & 3 & 4 & 5 \\
\hline Usoel ordenador porque me interssa la ternologia & 1 & & & & \\
\hline Me gutata aprender a hacer coseas nuevas con el ordenader & 1 & & & & \\
\hline 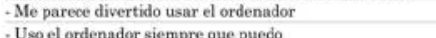 & 1 & & & & \\
\hline $\begin{array}{l}\text { Usse el ordenaldor sisempre que puedo } \\
\text { Usoel móvil siempre que puedo }\end{array}$ & $\frac{1}{1}$ & & & & \\
\hline - Intento evitar usuir rel ordenador porque no lo entiendo bien & 1 & & & & \\
\hline a la información sobre los últ & 1 & 2 & & & \\
\hline Conco & 1 & & & & 5 \\
\hline Me siento nervioso as tengo que usar el móvil & 1 & & & & \\
\hline $\begin{array}{l}\text { - Tengo miedode de usar el ordenador por si cometo errores } \\
\text { gue no se arreglar }\end{array}$ & 1 & 2 & 3 & 4 & 5 \\
\hline $\begin{array}{l}\text { Cuando me sale un mensaje de error en el ordenndor } \\
\text { me pongo nervioso }\end{array}$ & 1 & 2 & 3 & 4 & 5 \\
\hline Me preocupa hacer algo mal en el móvily borrar & 1 & 2 & 3 & 4 & 5 \\
\hline
\end{tabular}


RISKS OF INTERACTIVE COMMUNICATION IN ADOLESCENTS.

DIGITAL LITERACY DIAGNOSIS AND INTERVENTION

10. Cuando utilizamos Internet y las redes sociales, podemos hacer muchas cosas. Indica con que frecuencia realizas las siguientes:

\begin{tabular}{|c|c|c|c|c|c|}
\hline & Nunca & $\begin{array}{c}\text { Poras } \\
\text { vees }\end{array}$ & 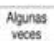 & assonsen & Seterpet \\
\hline 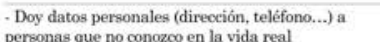 & 1 & 2 & 3 & 4 & 5 \\
\hline $\begin{array}{l}\text { Chateo o hablocon personas que he conocido } \\
\text { online y no acra a cura }\end{array}$ & 1 & 2 & 3 & 4 & 5 \\
\hline $\begin{array}{l}\text { Mando fotos mías a alguien que no conozco en } \\
\text { la vida real }\end{array}$ & 1 & 2 & 3 & 4 & 5 \\
\hline $\begin{array}{l}\text { Quedo en persona con alguien que he conocido } \\
\text { online }\end{array}$ & 1 & 2 & 3 & 4 & 5 \\
\hline $\begin{array}{l}\text {-Agrego a personas que no conozzo en la } \\
\text {. }\end{array}$ & 1 & 2 & 3 & 4 & 5 \\
\hline $\begin{array}{l}\text { Alguien se ha hecho pasar por mi en Internet } \\
\text { para publicar cosas como si fuese yo para }\end{array}$ & 1 & 2 & 3 & 4 & 5 \\
\hline $\begin{array}{l}\text { haserme daño } \\
\text { Han oolgado en Internet fotos o videos mios }\end{array}$ & 1 & 2 & 3 & 4 & 5 \\
\hline Se han burlado de mi con comentarios ofensivos o & 1 & 2 & 3 & 4 & 5 \\
\hline 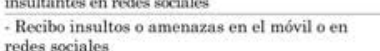 & 1 & 2 & 3 & 4 & 5 \\
\hline $\begin{array}{l}\text { Recibo en el móvil, correo... videos o imágenes } \\
\text { pornográficss }\end{array}$ & 1 & 2 & 3 & 4 & 5 \\
\hline $\begin{array}{l}\text { - Envio fotos mias en las que estoy desnudo o } \\
\text { muestro partes intimas de mi cuerpo por el } \\
\text { movil o por Internet }\end{array}$ & 1 & 2 & 3 & 4 & 5 \\
\hline $\begin{array}{l}\text { Recibo fotos de personas que conozoco online o en } \\
\text { la vida real) que estan desmudas o muestran } \\
\text { partes intimas de su cuerpo }\end{array}$ & 1 & 2 & 3 & 4 & 5 \\
\hline $\begin{array}{l}\text { Acabo sin querer en webs pornográficas } \\
\text { cuando uso Internet }\end{array}$ & 1 & 2 & 3 & 4 & 5 \\
\hline $\begin{array}{l}\text { Acabo sin querer en webs con contenidos } \\
\text { violentos o desararadables }\end{array}$ & 1 & 2 & 3 & 4 & 5 \\
\hline $\begin{array}{l}\text { Entro intencionadamente en páginas web } \\
\text { pornogríficas }\end{array}$ & 1 & 2 & 3 & 4 & 5 \\
\hline $\begin{array}{l}\text { Entro intencionadamente en páginas web con } \\
\text { contenidos siolentos o d desagradables }\end{array}$ & 1 & 2 & 3 & 4 & 5 \\
\hline $\begin{array}{l}\text { en las redes } \\
\text { ohacerledaño }\end{array}$ & 1 & 2 & 3 & 4 & 5 \\
\hline 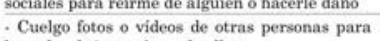 & & & 3 & 4 & 5 \\
\hline
\end{tabular}

11. Ahora piensa en tus padres o tutores, zon qué frecuencia suelen..."

\begin{tabular}{|c|c|c|c|c|c|}
\hline & Nunca & $\begin{array}{l}\text { Pocess } \\
\text { veres }\end{array}$ & 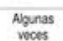 & 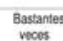 & Senper \\
\hline - Bloquear o prohibitre visitar ciertas páginas web & 1 & 2 & 3 & 4 & 5 \\
\hline $\begin{array}{l}\text { Limitar el tiempo que puedes estar online (en } \\
\text { el ordenador en el móvil. }\end{array}$ & 1 & 2 & 3 & 4 & 5 \\
\hline - Rastrear o vigilar lo que haces en línea, por & 1 & 2 & 3 & 4 & 5 \\
\hline Revisar tus conversaciones en WhatsApp & 1 & 2 & 3 & 4 & 5 \\
\hline & & & & & \\
\hline 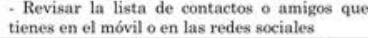 & 1 & ${ }^{2}$ & 3 & 4 & 5 \\
\hline $\begin{array}{l}\text { Ayudarte cuando te cuesta encontrar algo en } \\
\text { Internet }\end{array}$ & 1 & 2 & 3 & 4 & 5 \\
\hline $\begin{array}{l}\text { Explicarte por qué algunas páginas web son } \\
\text { buenanso manas }\end{array}$ & 1 & 2 & 3 & 4 & 5 \\
\hline - Hablar contigo sobre los beneficios y los & 1 & 2 & 3 & 4 & 5 \\
\hline 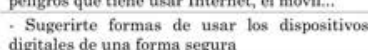 & 1 & 2 & 3 & 4 & 5 \\
\hline $\begin{array}{l}\text { Sugerinte formas de actuar con otras personas } \\
\text { cumando estis online }\end{array}$ & 1 & 2 & 3 & 4 & 5 \\
\hline 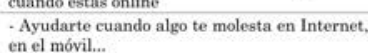 & 1 & 2 & 3 & 4 & 5 \\
\hline Han hablado contigo sobre que podrias hacer si & 1 & 2 & 3 & 4 & 5 \\
\hline
\end{tabular}

12. Pensando de nuevo en tus padres (o tutores), nos gustaria que nos indicases cuál es el .

Nivel de estudios de un tutor, padre o madre

Sin estudios o prim

Estudios primarios

Nivel de estudios del otro ther ponteonde

Estudios post.obligatorios no
universitarios Bachillerato

universitarios (Bachiller
Formación Profesional)

Sin estudios o pri

Estudios primarios onemplarios

obligatorios (ESO)

Estudios post-obligatorios no
universitarios

universitarios (Bachili
Formación Profesesional)

Estudios universitario

Mi familia es monoparental (solo
tengo un padre o madre).

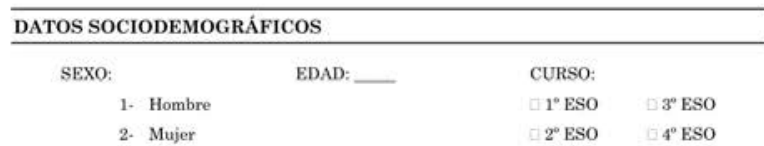




\section{Appendix 5.}

Contents of the App 



\section{PANTALLA DE INICIO}

Elegir género chico / chica ${ }^{19}$

\section{MENÚ}

- Mi historia
o ¡Hola!
o ¿Qué hago?
o Nos vamos de excursión
o Una pequeña pelea

- $\quad$ Test
o Aconseja a Lucía... (Test 1 )
o ¿Cómo protejo mi información en la red? (Test 2)

- Logros conseguidos

\section{HISTORIA}

\section{1. ¡HOLA!}

Contenidos incluidos en la narración:

Estrategia proactiva 1 - Cambiar los ajustes de privacidad

Estrategia comunicativa 1 - Hablar con amigos

Competencia digital Seguridad personal - Ítem 4

Narración:

¡Hola! Me llamo Lucía y tengo 15 años.

Me encantan las redes sociales, subir fotos a Instagram, hablar en WhatsApp y mandar Snaps a mis amigos... supongo que como a casi toda la gente de mi edad. Una

${ }^{19}$ Las siguientes pantallas cambiarán el género del protagonista en función del género. Se presenta la versión para chica 
RISKS OF INTERACTIVE COMMUNICATION IN ADOLESCENTS.

DIGITAL LITERACY DIAGNOSIS AND INTERVENTION

de las que más uso es Instagram, subo mogollón de fotos y me encanta ver las de mis amigas. Además, sigo a cantantes, a deportistas que me gustan o a influencers.

Pero hace poco, me di cuenta de que entre mis followers tenía a mucha gente que no conocía. De repente pensé que gente que yo no conocía de nada estaba viendo mis fotos y mis vídeos. La verdad es que me entró un poco de paranoia, porque en las fotos se podía ver donde vivo, lo que hago... Gente que yo no conocía sabía mucho de mí y, además, podían quedarse con mis fotos y... ja saber lo que iban a hacer con ellas! ¿Ysi se hacían pasar por mí?

Así que hablé con mi amiga Paula, le dije "tía, hay gente que me está siguiendo en Instagram que yo no conozco, y algunos parecen un poco raros". Menuda bronca me echó, me dijo que cómo no tenía la cuenta privada, que así yo podía decidir quien quería que viese mis fotos, y que era importante que solo gente que yo conocía viese lo que yo subía. Fui a Instagram y, en las opciones, elegí que la cuenta fuera privada, y después hice lo mismo en Twitter, es súper fácil de hacer.

Menos mal que hablé con ella, creo que siempre que tengas un problema hay que hablar con tus amigos, porque seguro que te van a ayudar.

\section{2. ¿QUÉ HAGO?}

\section{Contenidos incluidos en la narración:}

Estrategia proactiva 2 - Bloquear a un contacto

Estrategia proactiva 4 - Borrar las imágenes o los mensajes

Estrategia comunicativa 3 - Buscar ayuda online

Competencia digital Seguridad personal - Ítem 3

\section{Narración:}

Paula es una de mis mejores amigas, nos conocemos desde que éramos pequeñas. Así que siempre hablo con ella cuando tengo algún problema, cuando me gusta alguien... o 
cuando me pasa algo como lo que te conté antes de Instagram... Voy a terminar de contarte la historia.

Al día siguiente de que yo le contase eso, vino a mi casa a hacer los deberes. Como sabes, me encanta Instagram así que nos hicimos una foto para subirla. Cuando por fin Paula se decidió por un filtro (¡qué pesada, siempre tarda un montón), la subí a mi perfil. De repente alguien que yo no conocía nos puso un comentario súper desagradable, en plan diciendo que éramos feas y que vaya foto más ridícula. Yo quería quitar ese comentario, y que nadie lo viera, iqué vergüenza! Y encima yo no quería que ese chico me pudiese seguir más, jsi ni siquiera sabía quién era! Paula me contó que, aunque ya había puesto mi cuenta privada, los followers que tenía de antes, pues seguían siéndolo.

Así que decidimos buscar como podíamos borrar el mensaje y bloquear a ese contacto para que no me pudiese seguir más. Buscamos cómo hacerlo en Google y lo encontramos enseguida. Era súper fácil, solo había que hacer pulsar sobre el comentario y llevarlo a la papelera. Paula se había cabreado un montón, pero, por lo menos, vimos que en las redes sociales se pueden borrar los mensajes de personas que no conoces. Además, también puedes denunciar el comentario, para que los de Instagram no dejen que esa persona siga insultando. Al presionar el comentario eliges denunciar y ya está.

Paula me contó que su prima Valeria también tuvo que denunciar una vez una foto. Alguien había subido una foto de Valeria haciéndose pasar por ella, cuando la vio... menudo cabreo se pilló. La denunció, apretando los tres puntos de la foto y dándole a denunciar, y enseguida quitaron la foto.

Así que nosotras, después de denunciar el comentario, bloqueamos a ese chico. Paula me dijo "¿por qué no revisas toda la lista de followers? Seguro que tienes a desconocidos que no quieres..." Así que eso hice y bloqueé a varias personas que no conocía de nada. 
RISKS OF INTERACTIVE COMMUNICATION IN ADOLESCENTS.

DIGITAL LITERACY DIAGNOSIS AND INTERVENTION

En fin, que, entre Instagram, borrar comentarios, bloquear contactos de personas desconocidas... y ver las historias de gente del insti... iya eran las 8! Se nos había pasado la tarde volando y solo habíamos hecho los deberes de mates.

\section{NOS VAMOS DE EXCURSIÓN}

Contenidos incluidos en la narración:

Estrategia proactiva 3 - Proteger la información personal

Estrategia comunicativa 2 - Hablar con los padres

Competencia digital Seguridad personal - Ítem 1

\section{Narración:}

Esta semana tuvimos una excursión, fuimos a un museo de la ciencia. La verdad es que estuvo guay, aunque al principio pensábamos que iba a ser un rollo. Cuando íbamos de camino al museo, alguien me agregó a Snapchat, yo pensaba que sería uno de los de 4º, porque ellos también iban a la excursión. Le acepté, y seguí hablando con mis compañeras.

Llegamos las primeras al museo, así que mientras esperábamos a que llegasen el resto de compañeros, Paula y yo subimos una historia a Snapchat. En ese momento llegó la profe, nos dijo que nos dejáramos de móviles y entrásemos ya, que empezaba la visita. Cuando estábamos viendo la primera parte de la exposición, me llegó un snap. La profe nos había dicho que no estaba permitido usar el móvil en el museo, ¡pero yo quería verlo! Así que le dije que tenía que ir al baño y allí lo miré... Era del chico que me había agregado, pero no me sonaba de nada, y parecía mucho más mayor que cualquiera de los que van al instituto. Al ver el snap me asusté un montón, decía "Así que estás en el museo de ciencias, ¿quieres que quedemos?”. No sé cómo había conseguido mi nombre de usuario, pero el caso es que me había agregado, y iahora sabía dónde estaba! Me 
acordé de lo que me había dicho Paula y le bloqueé rápidamente, así ya no podría saber nada más de mí.

Por lo menos el resto de la excursión estuvo genial. Al terminar el museo nos dejaron tiempo libre y pudimos dar una vuelta por la zona, y nos reímos un montón. Sara, otra chica de nuestra clase, estaba muy emocionada, porque un chico de la otra clase le había dado un like a su foto de Instagram. ¡Así que todas subimos una foto para ver si a nosotras también nos daba un like!

Pero la verdad es que en todo el día no pude dejar de darle vueltas a lo que me había pasado... así que al llegar a casa se lo conté a mis padres. Tenía miedo por si me reñían o me quitaban el móvil, pero me dijeron que había hecho bien en bloquear al chico. Además, mi padre me explicó que ese chico había sabido donde estaba porque tenía activada la ubicación. Así que me enseñó como quitarlo en Snapchat y en Twitter. Es muy fácil, solo tienes que ir a los ajustes y elegir que nadie pueda ver tu ubicación, y he decidido que en Instagram no volveré a poner mi ubicación en mis publicaciones.

Me quedé más tranquila, porque no quería que mis padres me castigasen sin usar el móvil. Pero mi madre me dijo "No tienes que dejar de usar el ordenador o el móvil cuando pasen estas cosas", y mi padre añadió "claro Lucía, lo importante es que uses las redes sociales de forma segura y no des datos personales o tu ubicación a gente que no conoces". Desde entonces, tengo más cuidado de no poner mi ubicación y no dar mi número de teléfono o decir a que instituto voy a gente que solo he conocido online. Es mi información personal y no tiene que ser pública para gente que no conozco.

\section{UNA PEQUEÑA PELEA}

\section{Contenidos incluidos en la narración:}

Estrategia comunicativa 2 - Hablar con un amigo

Competencia digital Seguridad personal - Ítem 2 
RISKS OF INTERACTIVE COMMUNICATION IN ADOLESCENTS.

DIGITAL LITERACY DIAGNOSIS AND INTERVENTION

\section{Narración:}

Ayer pasaron un montón de cosas en clase. Primero, lo de Sofía. Sofía es una chica que va al A, pero en el recreo siempre está con nosotras. Ayer nos contó que había conocido en persona a un chico que había conocido en Twitter. Llevaban hablando un tiempo por WhatsApp, se seguían en Instagram, en Twitter... y querían conocerse en persona. Nos contó que su prima mayor le había acompañado, porque así, si había algo raro, si Daniel (que así se llama) no era quien decía ser, pues estaría más segura si estaba su prima con ella.

Es que en el insti siempre nos dan mucho la paliza con eso: "no conozcáis a nadie en persona que habéis conocido online si no os acompaña un adulto”. Y bueno, la verdad es que sí que tienen razón... una chica de $4^{\circ}$ nos contó una vez que ella había quedado con un chico que había conocido online, y que cuando llegó vio que era un señor súper mayor. Ella se asustó mucho porque él le intentó besar y le robó todo lo que tenía (el móvil, el dinero que llevaba...). Claro, en Internet nunca sabes si la persona con la que hablas te está mintiendo acerca de cómo es en verdad y hay muchos adultos que se hacen pasar por gente de nuestra edad. Así que por eso Sofía había ido con su prima. Lo bueno es que una vez que su prima vio que el chico era como decía (y no otra persona), ella y un amigo de Daniel, que también le había acompañado, les dejaron solos. Nos contó Sofía ique al final le besó!, y que este fin de semana seguramente vuelvan a quedar.

Lo otro que pasó es que Pablo y Carlos discutieron en el recreo. Los dos van a mi clase y juegan juntos en un equipo. Carlos está todo el día en Instagram, pero a Pablo no le gusta mucho... Y Carlos había subido una foto de los dos en la que Pablo salía horrible y, claro, Pablo se había enfadado. Carlos decía que si se había dejado hacer la foto pues que podía subirla. Pero todos le dijimos que no, que Pablo tenía razón. Antes de subir una foto en la que salga otra persona, hay que preguntarle si está de acuerdo. $Y$ lo mismo si subes información de otra persona. Pablo le dijo que, la próxima vez que subiese una foto sin su permiso, pediría a Instagram que la borrase. Al final Carlos entró en razón y se dio cuenta de que se había equivocado. Hay que tener cuidado con las fotos 
que subimos a las redes sociales, porque no es la primera vez que en mi grupo alguien se enfada por eso.

\section{TEST}

\section{ACONSEJA A LUCÍA...}

1. Cuando uso redes sociales como Instagram o Twitter, muchas veces subo fotos personales, ¿qué configuración debería tener en ellas?

a. Configuración pública

Respuesta: Esta no es la opción más adecuada... Personas que no conoces pueden ver tus fotos y vídeos, y esto puede ser peligroso.

b. Configuración privada

Respuesta: ¡Correcto! Así, solo las personas que tú quieres verán tus fotos

2- Si alguien que no conozco me sigue en redes sociales y yo no quiero que vea lo que pública... ¿qué puedo hacer?

a. Bloquear a ese contacto. Instagram, Twitter, WhatsApp... te dejan hacerlo Respuesta: ¡Muy bien! Presiona sobre el nombre del contacto y elige bloquear.

b. Nada, en las redes sociales todo el mundo puede seguir a quien quiera Respuesta: Vaya, te has equivocado...Cuando alguien que tú no conoces, o que no quieres que te siga, está entre tus followers, puedes bloquearlo. Presiona sobre el contacto y elige bloquear, así no podrá ver lo que públicas.

3- Cuando uso Instagram, Twitter o Snapchat, ¿es adecuado publicar información personal como mi dirección o número de teléfono?

a. Sí, no pasa nada porque la gente sepa esa información 
Respuesta: Deberías proteger tu información personal. Es peligroso que personas desconocidas sepan dónde vives o dónde estudias. Por precaución, no pongas esa información en las redes.

b. No, personas que no conozco en la realidad podrían ver esa información Respuesta: ¡Correcto! Hay que proteger la información personal. Es peligroso que personas desconocidas sepan dónde vives o dónde estudias. Por precaución, es mejor no poner esa información en las redes.

4- Alguien ha puesto un comentario desagradable en una foto mía, ¿qué hago?

a. Cabréate y apagar el móvil, es mejor no verlo

Respuesta: Cabrearse no es la solución, ni tampoco apagar el móvil. Si alguien ha puesto un comentario que no querías en tu foto, ¡bórralo! Presiona sobre el comentario y llévalo a la papelera. Y si crees que ese mensaje es ofensivo, ¡denúncialo en la app! Así esa persona no volverá a hacer esos comentarios.

b. Borrar el comentario, es tu perfil y si tú no quieres que ese comentario esté ahí, ¡bórralo!

Respuesta: ;Eso es! Si alguien pone un comentario que tú no quieres en tu foto, ¡bórralo! Presiona sobre el comentario y llévalo a la papelera. Y si crees que ese mensaje es ofensivo, ¡denúncialo en la app! Así esa persona no volverá a hacer esos comentarios.

5- He conocido a alguien en Instagram, y me ha pedido que quedemos en persona, ¿qué hago?

a. Habla con tus padres o con otro adulto de confianza

Respuesta: Correcto! Es más seguro que tus padres sepan con quien hablas. Y si decides conocer a alguien en persona, ¡nunca lo hagas solo! Si no te atreves a decírselo a tus padres, díselo a otro adulto (un primo mayor, un profesor...), alguien que pueda acompañarte para que conozcas a esa persona sin ningún peligro. 
b. Queda con esa persona, si habéis hablado online seguro que os conocéis bien.

Respuesta: Nunca te fies de las personas que conoces online. Aunque parezca que es tu amigo, no le conoces en la realidad y podría haberte mentido acerca de su identidad. Si quieres quedar, díselo a tus padres o a otro adulto (un primo mayor, un profesor...), alguien que pueda acompañarte para que conozcas a esa persona sin ningún peligro.

6- Acabo de ver que en Snapchat tengo activada la ubicación. Me preocupa porque no sé quitarla y no quiero que todo el mundo sepa dónde estoy en cada momento, ¿qué hago?

a. Pregunta a algún amigo, a lo mejor él sabe hacerlo... o podéis buscar en Google, o en la ayuda de Snapchat.

Respuesta: ¡Muy bien! Si no estás seguro de estar protegiendo bien tu privacidad, pregunta a algún amigo o busca ayuda online. De todas formas, es muy fácil: ve a ajustes y elige que solo tú (modo fantasma) puedas ver la ubicación.

b. Desinstala la aplicación, así nadie sabrá donde estás.

Respuesta: No hace falta que desinstales la aplicación, solo tienes que usarla de una forma segura. Puedes preguntar a un amigo como desactivar la ubicación o buscar ayuda online. De todas formas, es muy fácil: ve a ajustes y elige que solo tú (modo fantasma) puedas ver la ubicación.

\section{2. ¿CÓMO PROTEJO MI INFORMACIÓN EN LA RED?}

1- Me he dado cuenta de que mis contactos de Snapchat pueden saber dónde estoy en todo momento. Quiero quitarlo, porque no quiero que la gente pueda controlar donde estoy en cada momento. ¿Cómo lo hago? (Marca las opciones que sean correctas)

- Desinstala la app de Snapchat 
Respuesta: Respuesta incorrecta: No tienes que desinstalar la app ni cambiar tu nombre de usuario, solo elegir en ajustes el modo fantasma.

- En la pantalla de ajustes elige que solo tú puedas ver tu ubicación ¡Muy bien! No tienes que desinstalar la app ni cambiar tu nombre de usuario, solo elegir en ajustes el modo fantasma.

- Cambia tu nombre de usuario en Snapchat

Respuesta: Respuesta incorrecta: No tienes que desinstalar la app ni cambiar tu nombre de usuario, solo elegir en ajustes el modo fantasma.

2- Esta tarde me he hecho una foto con el equipo de baloncesto, hoy era el primer día de algunas personas. Así que yo creo que voy a subirla a Instagram para que todos la vean. No hace falta que pregunte a nadie..., ¿no?

a. Sí, pregunta a la gente que sale antes de subirla Respuesta: ¡Eso es! Antes de subir nada a la red, asegúrate de que las personas que aparecen en la foto o el vídeo están de acuerdo.

b. No, no les preguntes, es tu perfil de Instagram, no el suyo

Respuesta: La respuesta es incorrecta. Cuando subimos algo a la red tenemos que asegurarnos de que todas las personas que aparecen en la foto o en el vídeo están de acuerdo. Es tu perfil de Instagram, pero muchas personas van a poder ver esa foto o ese vídeo.

3- Acabo de ver que alguien que no conozco está poniendo mensajes en todas mis fotos, no quiero que siga escribiendo, no le conozco. ¿Debería borrar mi perfil de Instagram?

a. Sí, así no volverás a tener problemas

Respuesta: No tienes que dejar de usar una app porque haya usuarios que la utilicen de forma incorrecta. Si alguien ha publicado un mensaje que no te gusta en tu perfil, marca 
el mensaje y denúncialo. Haz lo mismo si un usuario te molesta, bloquéalo. Si continúa molestándote, habla con un adulto.

b. No, si un mensaje te molesta en las redes, denúncialo a la app para que lo borren, y sigue utilizando tu perfil de forma segura

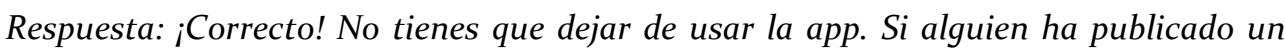
mensaje que no te gusta en tu perfil, marca el mensaje y denúncialo. Haz lo mismo si un usuario te molesta, bloquéalo. Si continúa molestándote, habla con un adulto.

4- ¿Cómo sé con quién estoy compartiendo la información que publico en las redes sociales? Solo quiero que lo vean mis amigos... (Marca las opciones que sean correctas)

- En Snapchat no se puede saber, todo el mundo puede ver lo que publicas. (incorrecto)

- Si usas Twitter, ve a los ajustes de privacidad y elige la opción 'Protege tus tweets', así solo podrán verlos tus seguidores. (correcto)

- Ve a ajustes en Snapchat y en el apartado 'Quién puede...' elige que solo tus amigos puedan contactarte y ver tu historia. (correcto)

- En Twitter menciona al amigo que quieres que lo vea, y solo lo verá él (incorrecto)

- Si usas Instagram, ve a las opciones de la cuenta y marca que sea solo privada

Respuesta: ¡Muy bien! Recuerda que en las redes sociales es importante mantener la privacidad para que solo las personas que queremos puedan ver nuestras publicaciones. 
RISKS OF INTERACTIVE COMMUNICATION IN ADOLESCENTS.

DIGITAL LITERACY DIAGNOSIS AND INTERVENTION

\section{LOGROS CONSEGUIDOS}

(representados con insignias)

1- Principiante (al leer la primera historia)

2- ¡Historia completada! (al leer todas las historias)

3- Eres un crack (al conseguir los primeros cinco puntos)

4- Gran consejero (al contestar bien a todas las preguntas del test 1)

5- Usuario avanzado (al contestar bien a todas las preguntas del test 2)

6- Experto en seguridad (al contestar bien a todas las preguntas del test $1 \mathrm{y}$ del test 2) 


\section{Appendix 6.}

Experiment: Pre-test

Questionnaire 



\section{Código secreto:}

(Para completar tu código secreto pon tu fecha de nacimiento seguido de las tres primeras letras de tu apellido. Por ejemplo, si naciste el 06 de julio de 2002, y tu apellido es Rodríguez, tu código secreto sería 06072002ROD)

\section{ESTUDIO SOBRE REDES SOCIALES}

La Universidad de Salamanca está haciendo una investigación sobre el uso de las redes sociales. Este cuestionario tiene varias preguntas relacionadas con el uso de las redes sociales. Te rogamos que contestes a todas las preguntas. Recuerda que no existen respuestas correctas o incorrectas, todas son válidas. Lo interesante para nosotros es conocer tu opinión sincera

La información solo se utilizará con fines científicos. Los datos se procesarán de forma colectiva y agregada, por lo que tus respuestas serán totalmente confidenciales y anónimas.

\section{MUCHAS GRACIAS POR TU COLABORACIÓN}

1. Para empezar, lee las siguientes afirmaciones y muestra tu nivel de acuerdo con la frase. Lee atentamente cada una de las afirmaciones y marca la opción que mejor te defina.

\begin{tabular}{|c|c|c|c|c|c|}
\hline & $\begin{array}{l}\text { Totalmente } \\
\text { desacuerdo }\end{array}$ & Desacuerdo & $\begin{array}{l}\text { Ni de acuerdo ni } \\
\text { desacuerdo }\end{array}$ & De acuerdo & $\begin{array}{l}\text { Totalmente de } \\
\text { acuerdo }\end{array}$ \\
\hline $\begin{array}{l}\text { - Sé desactivar la opción de mostrar mi } \\
\text { posición geográfica (ej. En Snapchat, } \\
\text { Instagram...) }\end{array}$ & 1 & 2 & 3 & 4 & 5 \\
\hline $\begin{array}{l}\text { - Sé cuándo puedo compartir imágenes y vídeos } \\
\text { en los que aparezcan otras personas }\end{array}$ & 1 & 2 & 3 & 4 & 5 \\
\hline $\begin{array}{l}\text { - Sé utilizar las herramientas para denunciar } \\
\text { un abuso (ej. suben una foto sin mi permiso) en } \\
\text { las redes sociales }\end{array}$ & 1 & 2 & 3 & 4 & 5 \\
\hline $\begin{array}{l}\text { - Sé configurar cualquiera de mis redes } \\
\text { sociales para elegir con quién compartir mi } \\
\text { información (amigos, amigos de mis amigos, } \\
\text { todo el mundo) }\end{array}$ & 1 & 2 & 3 & 4 & 5 \\
\hline
\end{tabular}


RISKS OF INTERACTIVE COMMUNICATION IN ADOLESCENTS

DIGITAL LITERACY DIAGNOSIS AND INTERVENTION

2. Cuando utilizamos Internet y las redes sociales, podemos hacer muchas cosas. Indica con qué frecuencia realizas las siguientes:

\begin{tabular}{|c|c|c|c|c|c|}
\hline & Nunca & $\begin{array}{l}\text { Pocas } \\
\text { veces }\end{array}$ & $\begin{array}{l}\text { Algunas } \\
\text { veces }\end{array}$ & $\begin{array}{l}\text { Bastantes } \\
\text { veces }\end{array}$ & Siempre \\
\hline $\begin{array}{l}\text { - Doy datos personales (dirección, teléfono...) a personas } \\
\text { que no conozco en la vida real }\end{array}$ & 1 & 2 & 3 & 4 & 5 \\
\hline $\begin{array}{l}\text { - Chateo o hablo con personas que he conocido online y } \\
\text { no cara a cara }\end{array}$ & 1 & 2 & 3 & 4 & 5 \\
\hline $\begin{array}{l}\text { - Mando fotos mías a alguien que no conozco en la vida } \\
\text { real }\end{array}$ & 1 & 2 & 3 & 4 & 5 \\
\hline - Quedo en persona con alguien que he conocido online & 1 & 2 & 3 & 4 & 5 \\
\hline $\begin{array}{l}\text { - Agrego, o me agregan, personas que no conozco en la } \\
\text { realidad a mis redes sociales }\end{array}$ & 1 & 2 & 3 & 4 & 5 \\
\hline
\end{tabular}

3. A continuación nos gustaría saber qué haces habitualmente cuando te enfrentas a las situaciones anteriores...

- $\quad$ Alguien desconocido te pide tus datos personales (dirección, teléfono...)

- Alguien desconocido habla contigo online

- Mandas fotos (o te pide fotos) alguien que no conoces en la vida real

- Quedas en persona (o te pide quedar) con alguien que has conocido online

- $\quad$ Agregas, o te agregan, personas que conoces online

Si no te ha ocurrido, piensa que harías en el caso de que te ocurriese:

\begin{tabular}{|c|c|c|c|c|}
\hline & $\begin{array}{c}\text { No lo hago I } \\
\text { no lo haría }\end{array}$ & $\begin{array}{l}\text { Casi nunca lo } \\
\text { hago / lo haría }\end{array}$ & $\begin{array}{c}\text { A menudo lo } \\
\text { hago / lo haría }\end{array}$ & $\begin{array}{l}\text { Lo hago / lo } \\
\text { haría siempre }\end{array}$ \\
\hline - Cambiar los ajustes de privacidad de mi red social & 1 & 2 & 3 & 4 \\
\hline - Bloquear a ese contacto & 1 & 2 & 3 & 4 \\
\hline - Proteger mi información personal (ej. borrar mi dirección) & 1 & 2 & 3 & 4 \\
\hline - Borrar el mensaje & 1 & 2 & 3 & 4 \\
\hline - Hablar con un amigo de ello & 1 & 2 & 3 & 4 \\
\hline - Hablar con mis padres de ellos & 1 & 2 & 3 & 4 \\
\hline - Buscar qué puedo hacer en Internet & 1 & 2 & 3 & 4 \\
\hline - No me preocupo por eso & 1 & 2 & 3 & 4 \\
\hline - Espero que se solucione solo & 1 & 2 & 3 & 4 \\
\hline - Dejo de usar el móvil u ordenador & 1 & 2 & 3 & 4 \\
\hline - Me desconecto de las redes sociales por un tiempo & 1 & 2 & 3 & 4 \\
\hline -Salgo de la web o de la aplicación & 1 & 2 & 3 & 4 \\
\hline
\end{tabular}

DATOS SOCIODEMOGRÁFICOS

SEXO:

EDAD

CURSO:

1- Hombre

$\square 1^{\circ} \mathrm{ESO} \quad \square 3^{\circ} \mathrm{ESO}$

2- Mujer

$\square 2^{\circ} \mathrm{ESO} \square 4^{\circ} \mathrm{ESO}$ 
Código secreto: _- - - - - - - - Para completar tu código secreto pon tu fecha de nacimiento seguido de las treer

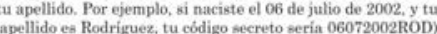

\section{ESTUDIO SOBRE REDES SOCIALES}

La Universidad de Salmmanca eath heciendo una invertincion sobre el uso de las redes sociales. Este cuestionario tiene varias preguntas relacionadas con el uso de las redes sociales. Te rogamos que contestes a o incorrectas, todas son validas. Lo interesante para nosotros es conocer tu opinión sincera. La información sólo se utilizará con fines cientifícos. Los datos se procesarán de forma colectiva y agregada, por lo que tus respuestas serán totalmente confidenciales $y$ anónimas.

MUCHAS GRACIAS POR TU COLABORACIÓN

1. Para empezar, lee las siguientes afirmaciones $y$ muestra tu nivel de acuerdo con la frase. .

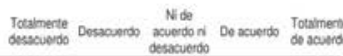

\begin{tabular}{|c|c|c|c|c|c|}
\hline $\begin{array}{l}\text { Sé desactivarar la opción de mostrar mi posicí́n } \\
\text { geográfica (ej. En Snapchat, Instagram...) }\end{array}$ & 1 & 2 & 3 & 4 & 5 \\
\hline $\begin{array}{l}\text {-Sé cuaindo puedo compartir imágenes y videos en los } \\
\text { que aparezzan otras perasonas }\end{array}$ & 1 & 2 & 3 & 4 & 5 \\
\hline $\begin{array}{l}\text { Sé utilizar las herramientas para denunciar un abuso } \\
\text { (ej. suben una foto sin mi permiso) en las redes sociales }\end{array}$ & 1 & 2 & 3 & ${ }^{4}$ & 5 \\
\hline $\begin{array}{l}\text { Sé confifurarar cualquiera de mis redes sociales para } \\
\text { elegig con quién nompartir mi información (amigos, } \\
\text { amigos de mis amigos, todo el mundo) }\end{array}$ & 1 & 2 & 3 & 4 & 5 \\
\hline
\end{tabular}

2. Cuando utilizamos Internet y las redes sociales, podemos hacer muchas cosas. Indica con
qué frecuencia realizas las siguientes:

\begin{tabular}{|c|c|c|c|c|c|}
\hline & sanea & 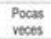 & 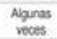 & Bustom & Sumper \\
\hline - Doy datos personales (direcocion, teleffono....) a & 1 & 2 & 3 & 4 & 5 \\
\hline $\begin{array}{l}\text { Chateo o hablo con personas que he conocido } \\
\text { onliney no carna acara }\end{array}$ & 1 & 2 & 3 & 4 & 5 \\
\hline Mando fotos mins a alguien que no conozeo en & 1 & 2 & 3 & 4 & 5 \\
\hline $\begin{array}{l}\text { lavida real } \\
\text { Quedo en persona con alguien que he conocido } \\
\text { online }\end{array}$ & 1 & 2 & 3 & 4 & 5 \\
\hline Agrego, o me agregan, personas que no & 1 & 2 & 3 & 4 & 5 \\
\hline
\end{tabular}

3. A continuación nos gustaria saber que haces habitualmente cuando te enfrentas a las

- Alguien desconocido te pide tus datos personales (dirección, teléf́no....)

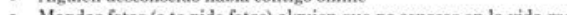

Quedas en persona (o te pide quedar) con alguien que has conocido onlino Agregas, o te agregan, personas que conoces online

Si no te ha ocurrido, piensa que harias en el caso de que te ocurriese

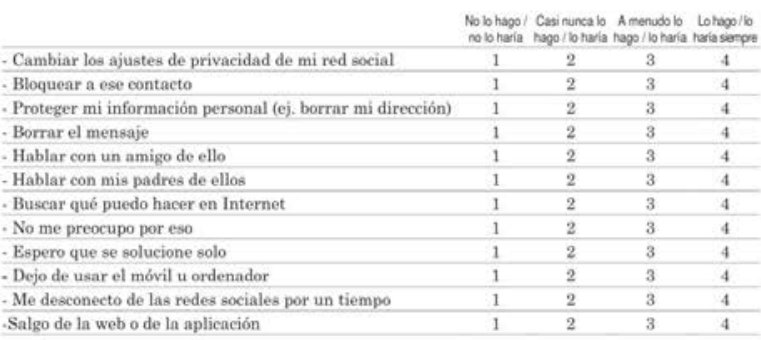

Me desconecto de las redes socilif

DATOS SOCIODEMOGRÁFICOS

SEXo:

1. Hombre

EDAD: 



\section{Appendix 7.}

Experiment: Post-test

Questionnaire 



\section{EXPERIMENTAL GROUP}

\section{Código secreto:}

(Para completar tu código secreto pon tu fecha de nacimiento seguido de las tres primeras letras de tu apellido. Por ejemplo, si naciste el 06 de julio de 2002, y tu apellido es Rodríguez, tu código secreto sería 06072002ROD)

\section{ESTUDIO SOBRE NUEVAS TECNOLOGÍAS}

La Universidad de Salamanca está haciendo una investigación sobre el uso de las nuevas tecnologías. Este cuestionario tiene varias preguntas relacionadas con este uso y te rogamos que contestes a todas las preguntas. Recuerda que no existen respuestas correctas o incorrectas, todas son válidas. Lo interesante para nosotros es conocer tu opinión sincera.

La información solo se utilizará con fines científicos. Los datos se procesarán de forma colectiva y agregada, por lo que tus respuestas serán totalmente confidenciales y anónimas.

\section{MUCHAS GRACIAS POR TU COLABORACIÓN}

1. Para empezar, nos gustaría que nos dieses tu opinión acerca de la aplicación que acabas de utilizar. Lee atentamente cada una de las afirmaciones y marca la opción que mejor te defina.

\begin{tabular}{|c|c|c|c|c|c|}
\hline & $\begin{array}{l}\text { Totalmente } \\
\text { desacuerdo }\end{array}$ & Desacuerdo & $\begin{array}{l}\text { Ni de acuerdo } \\
\text { ni desacuerdo }\end{array}$ & $\begin{array}{c}\text { De } \\
\text { acuerdo }\end{array}$ & $\begin{array}{l}\text { Totalmente } \\
\text { de acuerdo }\end{array}$ \\
\hline - He disfrutado con el uso de esta aplicación & 1 & 2 & 3 & 4 & 5 \\
\hline - Me gustaría volver a usar esta aplicación & 1 & 2 & 3 & 4 & 5 \\
\hline $\begin{array}{l}\text { - Me ha gustado que la app fuese interactiva y poder } \\
\text { elegir que ver }\end{array}$ & 1 & 2 & 3 & 4 & 5 \\
\hline - La aplicación era fácil de usar & 1 & 2 & 3 & 4 & 5 \\
\hline $\begin{array}{l}\text { - Era fácil navegar entre las diferentes opciones de la } \\
\text { aplicación }\end{array}$ & 1 & 2 & 3 & 4 & 5 \\
\hline -El contenido de la aplicación era claro y fácil de entender & 1 & 2 & 3 & 4 & 5 \\
\hline - El contenido de la aplicación es útil para mi & 1 & 2 & 3 & 4 & 5 \\
\hline
\end{tabular}


2. Por favor, piensa en las historias que acabas de ver. En relación con su protagonista (Lucía o Hugo), indica en qué medida has experimentado lo siguiente al ver su historia:

\begin{tabular}{|c|c|c|c|c|c|}
\hline & Nada & Poco & Algo & Bastante & Mucho \\
\hline $\begin{array}{l}\text { - He comprendido la forma de actuar, pensar o sentir del/de } \\
\text { la protagonista (Lucía o Hugo) }\end{array}$ & 1 & 2 & 3 & 4 & 5 \\
\hline $\begin{array}{l}\text { - He entendido los sentimientos o emociones del/de la } \\
\text { protagonista }\end{array}$ & 1 & 2 & 3 & 4 & 5 \\
\hline $\begin{array}{l}\text { - He intentado imaginar los sentimientos, pensamientos y } \\
\text { reacciones del/de la protagonista }\end{array}$ & 1 & 2 & 3 & 4 & 5 \\
\hline $\begin{array}{l}\text { - He intentado ver las cosas desde el punto de vista del/de la } \\
\text { protagonista }\end{array}$ & 1 & 2 & 3 & 4 & 5 \\
\hline - Me he identificado con el/la protagonista & 1 & 2 & 3 & 4 & 5 \\
\hline - Me he sentido como si fuera el/la protagonista & 1 & 2 & 3 & 4 & 5 \\
\hline
\end{tabular}

3. Ahora nos gustaría conocer cómo has reaccionado hacia la historia en su conjunto. Para cada pregunta o ítem marca con un círculo el número que mejor represente tu opinión sobre la historia que acabas de ver.

\begin{tabular}{|c|c|c|c|c|c|}
\hline & Nada & Poco & Algo & Bastante & Mucho \\
\hline $\begin{array}{l}\text { - Pude imaginar que yo mismo estaba en el lugar de los } \\
\text { hechos descritos en la historia }\end{array}$ & 1 & 2 & 3 & 4 & 5 \\
\hline $\begin{array}{l}\text { - Me sentí involucrado o implicado con la narración mientras } \\
\text { la veía }\end{array}$ & 1 & 2 & 3 & 4 & 5 \\
\hline - Mientras veía la historia quería saber cómo iba a terminar & 1 & 2 & 3 & 4 & 5 \\
\hline - Lo ocurrido en la historia me ha afectado emocionalmente & 1 & 2 & 3 & 4 & 5 \\
\hline
\end{tabular}

4. A continuación, se presentan una serie de afirmaciones relacionadas con tu uso de las nuevas tecnologías. Lee cada una de las siguientes afirmaciones y muestra tu nivel de acuerdo con cada una de ellas.

\begin{tabular}{|c|c|c|c|c|c|}
\hline & $\begin{array}{l}\text { Totalmente } \\
\text { desacuerdo }\end{array}$ & Desacuerdo & $\begin{array}{l}\text { Ni de acuerdo } \\
\text { ni desacuerdo }\end{array}$ & $\begin{array}{c}\text { De } \\
\text { acuerdo }\end{array}$ & $\begin{array}{l}\text { Totalmente } \\
\text { de acuerdo }\end{array}$ \\
\hline $\begin{array}{l}\text { - Sé desactivar la opción de mostrar mi posición } \\
\text { geográfica (ej. En Snapchat, Instagram...) }\end{array}$ & 1 & 2 & 3 & 4 & 5 \\
\hline $\begin{array}{l}\text { - Sé cuándo puedo compartir imágenes y vídeos en los } \\
\text { que aparezcan otras personas }\end{array}$ & 1 & 2 & 3 & 4 & 5 \\
\hline $\begin{array}{l}\text { - Sé utilizar las herramientas para denunciar un abuso } \\
\text { (ej. suben una foto sin mi permiso) en las redes sociales }\end{array}$ & 1 & 2 & 3 & 4 & 5 \\
\hline $\begin{array}{l}\text { - Sé configurar cualquiera de mis redes sociales para } \\
\text { elegir con quién compartir mi información (amigos, } \\
\text { amigos de mis amigos, todo el mundo) }\end{array}$ & 1 & 2 & 3 & 4 & 5 \\
\hline
\end{tabular}


5. Cuando utilizamos Internet y las redes sociales, pueden ocurrir muchas cosas. Nos gustaría saber qué harías si te enfrentases a una de las siguientes situaciones:

- Alguien desconocido te pide tus datos personales (dirección, teléfono...)

- Alguien desconocido habla contigo online

- Mandas fotos (o te pide fotos) alguien que no conoces en la vida real

- Quedas en persona (o te pide quedar) con alguien que has conocido online

- $\quad$ Agregas, o te agregan, personas que conoces online

\begin{tabular}{lcccc} 
& No lo haría & $\begin{array}{c}\text { Casi nunca lo } \\
\text { haría }\end{array}$ & $\begin{array}{c}\text { Lo haría a } \\
\text { menudo }\end{array}$ & $\begin{array}{c}\text { Lo haría } \\
\text { siempre }\end{array}$ \\
\hline - Cambiar los ajustes de privacidad de mi red social & 1 & 2 & 3 & 4 \\
\hline - Bloquear a ese contacto & 1 & 2 & 3 & 4 \\
\hline - Proteger mi información personal (ej. borrar mi dirección) & 1 & 2 & 3 & 4 \\
\hline - Borrar el mensaje & 1 & 2 & 3 & 4 \\
\hline - Hablar con un amigo de ello & 1 & 2 & 3 & 4 \\
\hline - Hablar con mis padres de ellos & 1 & 2 & 3 & 4 \\
\hline - Buscar qué puedo hacer en Internet & 1 & 2 & 3 & 4 \\
\hline - No preocuparme por eso & 1 & 2 & 3 & 4 \\
\hline - Esperar que se solucione solo & 1 & 2 & 3 & 4 \\
\hline - Dejar de usar el móvil u ordenador & 1 & 2 & 3 & 4 \\
\hline - Desconectarme de las redes sociales por un tiempo & 1 & 2 & 3 & 4 \\
\hline - Salir de la web o de la aplicación & 1 & 2 & 3 & 4
\end{tabular}

DATOS SOCIODEMOGRÁFICOS

SEXO:

EDAD

CURSO:

1- Hombre

$1^{\circ} \mathrm{ESO} \square 3^{\circ} \mathrm{ESO}$

2- Mujer

$\square 2^{\circ} \mathrm{ESO} \square 4^{\mathrm{o}} \mathrm{ESO}$ 
RISKS OF INTERACTIVE COMMUNICATION IN ADOLESCENTS.

DIGITAL LITERACY DIAGNOSIS AND INTERVENTION

Código secreto:

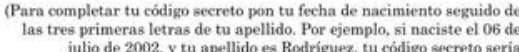

julio de 2002 , y tu apellido es Rodríguez, tu códigig secreto seria

\section{ESTUDIO SOBRE NUEVAS TECNOLOGÍAS}

La Univer: tecnologias. Este cuestionario tiene varias preguntas relacionadas con este uso y to rogamos que contestes a todas las preguntas. Recuerda que no existen respuestas correctas o incorrectas, todas son válidas. Lo interesante para nosotros es conocer tu opinión sincer

La información sólo se utilizará con fines cientificos. Los datos se procesarán de forma colectiva y agregada, por lo que tus respuestas serán totalmente confidenciales y ańnimas

MUCHAS GRACIAS POR TU COLABORACIÓN

1. Para empezar, nos gustaria que nos dieses tu opinión acerca de la aplicación que
acabas de utilizar. Lee atentamente cada una de las afirmaciones y marca la que mejor te defina.

\begin{tabular}{|c|c|c|c|c|c|}
\hline \multirow{3}{*}{$\begin{array}{l}\text { - He disfrutado con el uso de esta aplicación } \\
\text { - Me gustaria volver a usar esta aplicación }\end{array}$} & \multicolumn{3}{|c|}{ 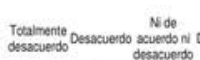 } & \multicolumn{2}{|c|}{ 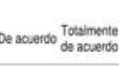 } \\
\hline & 1 & 2 & 3 & & 5 \\
\hline & 1 & 2 & & & \\
\hline $\begin{array}{l}\text { Me ha gustado que la app fuese interactiva y poder } \\
\text { legir uqu ver }\end{array}$ & 1 & 2 & 3 & 4 & 5 \\
\hline $\begin{array}{l}\text { legiri que ver } \\
\text { La aplicación era fficil de usar }\end{array}$ & 1 & 2 & 3 & 4 & 5 \\
\hline $\begin{array}{l}\text { Era fícil navegar entre las diferentes opciones de la } \\
\text { alplicacion }\end{array}$ & 1 & 2 & 3 & 4 & 5 \\
\hline $\begin{array}{l}\text { El contenido de la aplicación era claro y fícil de } \\
\text { entender }\end{array}$ & 1 & 2 & 3 & 4 & 5 \\
\hline El contenido de la aplicación es útil para n & & 2 & 3 & & \\
\hline
\end{tabular}

3. Ahora nos gustaria conocer cómo has reaccionado hacia la historia en su conjunto. Para cada pregunta o item marca con un circulo el número que mejor
represente tu opinión sobre la historia que acabas de ver.

\begin{tabular}{|c|c|c|c|c|c|}
\hline & Notat & $P_{0 \times 0}$ & $A_{90}$ & Bassonte & woro \\
\hline $\begin{array}{l}\text { Pude imaginar que yo mismo estaba en el lugar de } \\
\text { los hechos descritos en la historia }\end{array}$ & 1 & ${ }^{2}$ & 3 & 4 & 5 \\
\hline $\begin{array}{l}\text { Me senti involucrado o implicado con la narración } \\
\text { mientras la veia }\end{array}$ & 1 & 2 & ${ }^{3}$ & 4 & 5 \\
\hline $\begin{array}{l}\text { Meientras veía la historia queria saber ómo iba a } \\
\text { terrminur }\end{array}$ & 1 & 2 & 3 & 4 & 5 \\
\hline $\begin{array}{l}\text { Lo courrido on la historia me ha afectado } \\
\text { emocionalmente }\end{array}$ & 1 & 2 & 3 & 4 & 5 \\
\hline
\end{tabular}
4. A continuación, se presentan una serie de afirmaciones relacionadas con tu uso de
las nuevas teconologias. Lee cada una de las siguientes afirmaciones y muestra tu
nivel de acuerdo oon cada una de ellas.

\begin{tabular}{|c|c|c|c|c|c|}
\hline & $\begin{array}{l}\text { Toaster } \\
\text { dosson }\end{array}$ & & 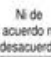 & & 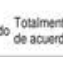 \\
\hline 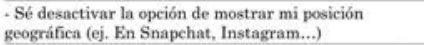 & 1 & 2 & 3 & 4 & 5 \\
\hline $\begin{array}{l}\text {-Sé cuándo puedo compartiri imageness y videos en los } \\
\text { que aparezcan otras personas }\end{array}$ & 1 & 2 & 3 & 4 & 5 \\
\hline 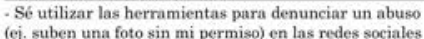 & 1 & 2 & 3 & 4 & 5 \\
\hline 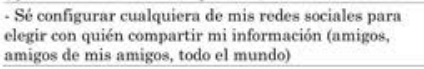 & 1 & 2 & 3 & 4 & 5 \\
\hline
\end{tabular}


5. Cuando utilizamos Internet $y$ las redes sociales, pueden ocurrir muchas cosas. Nos
gustaris saber qué harias si te enfrentases a una de las siguientes situaciones:

- Alguien desconocido te pide tus datos personales (dirección, teléf́no...)

Mandas fotos fote te pide fotas) albo online

- Mandas fotos (o te pide fotos) alguien que no conoces en la vida real

Q Quedas en persona (o te pide quedar) con alguien
Agregas, o te agregan, personas que conoces onlin

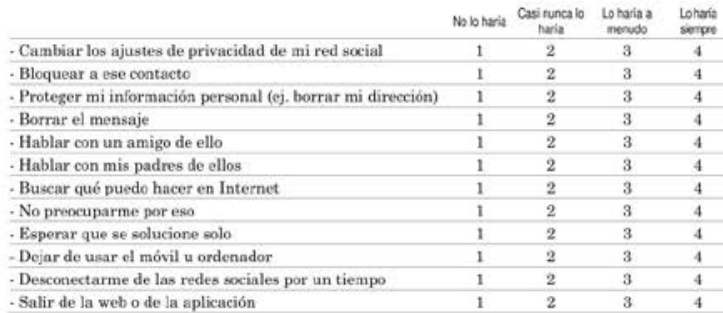

DATOS SOCIODEMOGRÁFICO

SEXO

1. Hombre

EDAD:

Curso:

$1^{\circ}$ ESO $\square 3^{\circ} \mathrm{ESO}$

$\square^{\circ}$ ESO $\square 4^{\circ} \mathrm{ESO}$ 


\section{CONTROL GROUP}

\section{Código secreto:}

(Para completar tu código secreto pon tu fecha de nacimiento seguido de las tres primeras letras de tu apellido. Por ejemplo, si naciste el 06 de julio de 2002, y tu apellido es Rodríguez, tu código secreto sería 06072002ROD)

\section{ESTUDIO SOBRE NUEVAS TECNOLOGÍAS}

La Universidad de Salamanca está haciendo una investigación sobre el uso de las nuevas tecnologías. Este cuestionario tiene varias preguntas relacionadas con este uso y te rogamos que contestes a todas. No existen respuestas correctas o incorrectas, todas son válidas. Lo interesante para nosotros es conocer tu opinión sincera La información solo se utilizará con fines científicos. Los datos se procesarán de forma colectiva y agregada, por lo que tus respuestas serán totalmente confidenciales y anónimas.

MUCHAS GRACIAS POR TU COLABORACIÓN

1. Para empezar, lee las siguientes afirmaciones y muestra tu nivel de acuerdo con la frase. Lee atentamente cada una de las afirmaciones y marca la opción que mejor te defina.

\begin{tabular}{|c|c|c|c|c|c|}
\hline & $\begin{array}{l}\text { Totalmente } \\
\text { desacuerdo }\end{array}$ & Desacuerdo & $\begin{array}{l}\text { Ni de acuerdo } \\
\text { ni desacuerdo }\end{array}$ & $\begin{array}{c}\text { De } \\
\text { acuerdo }\end{array}$ & $\begin{array}{l}\text { Totalmente } \\
\text { de acuerdo }\end{array}$ \\
\hline $\begin{array}{l}\text { - Sé desactivar la opción de mostrar mi posición } \\
\text { geográfica (ej. En Snapchat, Instagram...) }\end{array}$ & 1 & 2 & 3 & 4 & 5 \\
\hline $\begin{array}{l}\text { - Sé cuándo puedo compartir imágenes y vídeos en los } \\
\text { que aparezcan otras personas }\end{array}$ & 1 & 2 & 3 & 4 & 5 \\
\hline $\begin{array}{l}\text { - Sé utilizar las herramientas para denunciar un abuso } \\
\text { (ej. suben una foto sin mi permiso) en las redes sociales }\end{array}$ & 1 & 2 & 3 & 4 & 5 \\
\hline $\begin{array}{l}\text { - Sé configurar cualquiera de mis redes sociales para } \\
\text { elegir con quién compartir mi información (amigos, } \\
\text { amigos de mis amigos, todo el mundo) }\end{array}$ & 1 & 2 & 3 & 4 & 5 \\
\hline
\end{tabular}


2. Cuando utilizamos Internet y las redes sociales, pueden ocurrir muchas cosas. Nos gustaría saber qué harías si te enfrentases a una de las siguientes situaciones:

- $\quad$ Alguien desconocido te pide tus datos personales (dirección, teléfono...)

- Alguien desconocido habla contigo online

- Mandas fotos (o te pide fotos) alguien que no conoces en la vida real

- Quedas en persona (o te pide quedar) con alguien que has conocido online

- Agregas, o te agregan, personas que conoces online

\begin{tabular}{lcccc} 
& No lo haría Casi nunca lo & $\begin{array}{c}\text { Lo haría a } \\
\text { haría }\end{array}$ & $\begin{array}{c}\text { Loharía } \\
\text { siempre }\end{array}$ \\
\hline - Cambiar los ajustes de privacidad de mi red social & 1 & 2 & 3 & 4 \\
\hline - Bloquear a ese contacto & 1 & 2 & 3 & 4 \\
\hline - Proteger mi información personal (ej. borrar mi dirección) & 1 & 2 & 3 & 4 \\
\hline - Borrar el mensaje & 1 & 2 & 3 & 4 \\
\hline - Hablar con un amigo de ello & 1 & 2 & 3 & 4 \\
\hline - Hablar con mis padres de ellos & 1 & 2 & 3 & 4 \\
\hline - Buscar qué puedo hacer en Internet & 1 & 2 & 3 & 4 \\
\hline - No me preocupo por eso & 1 & 2 & 3 & 4 \\
\hline - Espero que se solucione solo & 1 & 2 & 3 & 4 \\
\hline - Dejo de usar el móvil u ordenador & 1 & 2 & 3 & 4 \\
\hline - Me desconecto de las redes sociales por un tiempo & 1 & 2 & 3 & 4 \\
\hline - Salgo de la web o de la aplicación & 1 & 2 & 3 & 4 \\
\hline
\end{tabular}

\section{DATOS SOCIODEMOGRÁFICOS}

SEXO

1. Hombre

2- Mujer
CURSO:

$\square 1^{\circ} \mathrm{ESO} \quad \square 3^{\circ} \mathrm{ESO}$

$\square 2^{\circ} \mathrm{ESO} \quad \square 4^{\circ} \mathrm{ESO}$ 
RISKS OF INTERACTIVE COMMUNICATION IN ADOLESCENTS.

DIGITAL LITERACY DIAGNOSIS AND INTERVENTION

Código secreto:

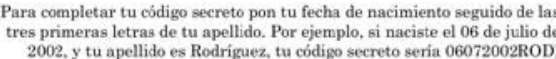

\section{ESTUDIO SOBRE NUEVAS TECNOLOGÍAS}

La Universidad de Salamanca está haciendo una investigación sobre el uso de las nuevas tecnologias. Este cuestionario tiene varias preguntas relacionadas con este uso y to rogamos que contestes a todes. No existen respuestas correctas o incorrectas, todes son

La información sólo se utilizará con fines cientificos. Los datos se procesarán de form colectiva y agregada, por lo que tus respuestas serán totalmente confídenciales y anónimas.

MUCHAS GRACIAS POR TU COLABORACIÓN

1. Para empezar, lee las siguientes afirmaciones y muestra tu nivel de acuerdo con la frase

\begin{tabular}{|c|c|c|c|c|c|}
\hline & 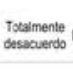 & & & & 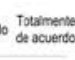 \\
\hline $\begin{array}{l}\text { Sé desactivar la opción de mostrar mi posición } \\
\text { geogrififica (ej. En Snapchat, Instagram...) }\end{array}$ & 1 & 2 & 3 & 4 & 5 \\
\hline $\begin{array}{l}\text { Sé cuándo puedo compartir imágenes y vídeos en } \\
\text { los que aparezcan otras personas }\end{array}$ & in 1 & 2 & 3 & 4 & 5 \\
\hline $\begin{array}{l}\text { Sé utilizar las herramientas para denunciar un } \\
\text { abuso (sj. suben una foto sin mi permiso) en las } \\
\text { redes sociales }\end{array}$ & 1 & 2 & 3 & 4 & 5 \\
\hline $\begin{array}{l}\text { Sé configirarar cualaquiera de mis redes sociales } \\
\text { para elegegir con quién oompartit mi información } \\
\text { (amigos, amigos de mis amigos, todo el mundo) }\end{array}$ & 1 & 2 & 3 & 4 & 5 \\
\hline
\end{tabular}

Cuando utilizamos Internet y las redes sociales, pueden ocurrir muchas cosas. Nos fustaria saber

: Alguien desconocido te pide tus datos personales (dirección, teléf́ono....)

Mandas fotos (o te pide fotos) alguien que no conoces en la vida real

- Quedas en persona (o te pide quedar) con alguien que has conocido online

\begin{tabular}{|c|c|c|c|c|}
\hline & Nolo hat: & 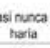 & 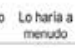 & 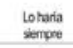 \\
\hline Cambiar los ajustes de privacidad de mi red social & 1 & 2 & 3 & \\
\hline - Bloquear a ese contacto & 1 & 2 & 3 & \\
\hline $\begin{array}{l}\text { Proteger mi información personal (ej. borrar mi } \\
\text { dirección) }\end{array}$ & 1 & ${ }^{2}$ & 3 & \\
\hline Borrar el mensaje & 1 & 2 & 3 & \\
\hline - Hablar con un amigo de ello & 1 & 2 & 3 & \\
\hline - Hablar con mis padres de ellos & 1 & 2 & 3 & \\
\hline Buscar qué puedo hacer en Internet & 1 & 2 & 3 & \\
\hline Nome & 1 & 2 & 3 & \\
\hline iones s & 1 & 2 & 3 & \\
\hline Ir el móvil u ordenac & 1 & 2 & 3 & \\
\hline Me desconecto de las redes sociales p & 1 & 2 & 3 & \\
\hline & & & & \\
\hline
\end{tabular}

Salmo de la webo de he apsocián

DATOS SOCIODEMOGRÁFICOS

SEXO:
1. Hombre
2. Mujer


Appendix 8.

List of Variables in English 



\section{Digital Literacy Scale: 6 factors and 28 items}

(5-point Likert scale from $1=$ Strongly disagree to $5=$ Strongly agree $)$

I know how to...

\section{Technological skill}

- I know how to bookmark a website I like so I can view it later

- I always know how to download/save a photo I found online

- I know how to download information I found online

- I always know how to connect to a Wi-Fi network, no matter the device or where I am

- I know how to use shortcut keys (e.g., CTRL+C o cmd+C for copy)

- I do not like downloading apps for smartphones as I find difficult to learn how to use them (recoded)

- If I want to install new programs on my computer, I will ask someone to do it for me because I do not know (recoded)

Personal security skill

- I know how to deactivate the function showing my geographical position (e.g., Facebook, apps)

- I know when I can post pictures and videos of other people online

- I know how to use 'report abuse' buttons on social media sites (e.g., someone uses my photo without my permission)

- I know how to change the sharing settings of social media to choose what others can see about me (friends of friends, friends only, only me)

Critical skill

- I know how to compare different sources to decide if information is true

- I know how to determine if the information I find online is reliable 
- I know how to identify the author of the information and evaluate their reliability

- I know how to compare different apps in order to choose which one is most reliable and secure

- If I meet someone online, I know how to check if their profile is real

Device security skill

- I use software to detect and remove viruses

- I know how to detect a virus in my digital device

- I know how to block unwanted or junk mail/spam

- If something doesn't work occurs while I am using a device (computer, smartphone, etc.), I usually know what it is and how to fix the problem

Informational skill

- I find hard to decide what the best keywords are for online searching (recoded)

- I find confusing the way in which many websites are designed (recoded)

- Sometimes I find difficult to determine how useful the information is for my purpose (recoded)

- I get tired when looking for information online

- Sometimes I end up on websites without knowing how I got there

Communication skill

- Depending on who I want to communicate with, it is better to use one method over the other (make a call, send a WhatsApp message, send an email, etc.)

- I know how to send any file to a contact using a smartphone

- No matter with who I communicate: emojis are always useful (recoded) 


\section{Parental Mediation: 2 factors and 12 items}

(5-point Likert scale from $1=$ Never to $5=$ Always $)$

How often do your parents...?

Restrictive parental mediation

- $\quad$ Forbid or block certain websites

- Restrict the amount of time you spend online (on the computer, on the smartphone, etc.)

- Monitor or track what you are doing online, such as checking your search history

- $\quad$ Check your messages in WhatsApp, Facebook, etc.

- Check which friends or contacts you have on your smartphone or on your social networking sites

Active parental mediation

- Help you when something is difficult to do or find on the Internet

- Explain why some web-sites are good or bad

- Talk to you about the benefits and dangers of using the Internet, the smartphone, etc.

- $\quad$ Suggest ways to use your digital devices safely

- Suggest ways to behave towards other people online

- Help you when something bothers you on the Internet, on the smartphone, etc.

- Talk to you about what you would do if something on the Internet, on the smartphone... bothers you 


\section{Online Risk Behaviours: 5 factors and 16 items}

(5-point Likert scale from $1=$ Never to $5=$ Always $)$

How often do you ...?

Contact with strangers

- Give info about yourself (address, phone number, etc.) to another person that you have not met face to face

- Chat with people you meet online

- Send pictures of yourself to people you meet online

- Meet face-to-face people that you first met online

- Add people that you have not met face to face to your social media sites (e.g., Facebook)

Exposure to pornography

- Receive sexual images or videos on my phone, my email, etc.

- Receive photos from people you know (online or face to face) of themselves naked or of their private parts

- End up on porn sites accidentally

- Visit porn sites on purpose

Exposure to violence

- End up accidentally on sites with violent or gruesome pictures

- Visit sites with violent or gruesome pictures on purpose

Cyberbullying victim

- Someone posts photos or videos of yourself to hurt you or make fun of you

- Someone makes fun of you with hurtful or insulting comments on social media sites 
- Receive insults or threats on the phone or on social media sites

\section{Cyberbullying perpetrator}

- Post hurtful or insulting comments on social media sites to hurt someone or to make fun of them.

- Post photos or videos of other people to hurt them or make fun of them 
RISKS OF INTERACTIVE COMMUNICATION IN ADOLESCENTS.

DIGITAL LITERACY DIAGNOSIS AND INTERVENTION

\section{Online Opportunities: 3 factors and 10 items}

(5-point Likert scale from $1=$ Never to $5=$ Several times a day)

How often do you...?

Communication

- Use the Internet

- Use the Email

- Use social media sites

- Use instant messaging programs

Entertainment

- Use game apps

- Use videogames / computer games

- Use online games

Multimedia

- Download music or films

- Make video calls

- Use editing software 


\section{Positive ICT attitude: 1 factor and 11 items}

(5-point Likert scale from $1=$ Strongly disagree to $5=$ Strongly agree)

To what extent do you agree or disagree with the following statements?

- It is very important to me to study with a computer

- I enjoy using the Internet to find out information

- It is more fun to do my homework using a computer than without a computer

- Using digital technologies (e.g., computer, Internet, tablet, etc.) makes learning more fun

- Teachers should use more digital technologies in their classes

- I use the computer because I am interested in the technology

- I like learning how to do new things using a computer

- Using the computer is fun

- I use the computer whenever I can

- I use the smartphone whenever I can

- I am interested in information about the latest mobile phones 
RISKS OF INTERACTIVE COMMUNICATION IN ADOLESCENTS.

DIGITAL LITERACY DIAGNOSIS AND INTERVENTION

\section{Technology anxiety: 1 factor and 9 items}

(5-point Likert scale from $1=$ Strongly disagree to $5=$ Strongly agree $)$

To what extent do you agree or disagree with the following statements?

- I feel tense when I am about to use the computer

- Doing homework with a computer would make me very nervous

- Computers make me feel uneasy and confused

- I avoid using computers because I do not understand them

- I feel tense when I am about to use a computer

- I feel nervous when I am about to use the mobile phone

- I hesitate to use a computer for fear of making mistakes that I cannot correct

- I feel nervous when error message appears on the computer screen

- It scares me to think that I could cause the smartphone to destroy some data by mistake 


\section{Coping Strategies: 4 factors and 12 items}

(4-point Likert scale from ranging from $1=\mathrm{I}$ did not/would not do this to $4=\mathrm{I}$ would probably do this)

Did you do (or would you do) any of these things afterwards?

Proactive

- Change privacy settings

- Block contact person

- Protect personal information

- Delete the message

\section{Communicative}

- $\quad$ Talk with friend(s)

- Talk with parents

- Seek online support

Passive

- Don't care about what happened

- Hope the problem goes away by itself

Avoidance

- Go away from computer or device

- Go offline for a while

- Click away, go away from website, profile or platform 
RISKS OF INTERACTIVE COMMUNICATION IN ADOLESCENTS.

DIGITAL LITERACY DIAGNOSIS AND INTERVENTION

\section{Mobile application acceptance: 1 factor and 7 items}

(5-point Likert scale from $1=$ Strongly disagree to $5=$ Strongly agree)

To what extent do you agree or disagree with the following statements?

- The app was enjoyable to use

- I would like to use this app again

- I liked the interactivity and being able to choose what to do

- This mobile application was easy to use

- Navigation through this application was easy

- The content of the app was clear and understandable

- The content of the app is useful for me 


\section{Appendix 9.}

Media Coverage of the Thesis 

The results of the studies in the doctoral thesis were covered by some Spanish media:

Radio Nacional de España

- Bassolas, S. (Subdirector). (2018, March 10). El mòbil: el nou generador de conflictes familiars [Radio broadcast]. In S. Tarragona (Producer), Amics i coneguts. Barcelona, Spain: RNE. Retrieved from: http://www.rtve.es/alacarta/audios/amics-i-coneguts/amics-conegutsreport-mobil-nou-generador-conflictes-familiars/4509205/

La Vanguardia

- $\quad$ Printed newspaper: Ryus, M. (2018, February 05). Restringir el móvil a los hijos no es buena idea. La Vanguardia, pp. 22-23.

- Online newspaper: Ryus, M. (2018, February 05). Restringir el móvil a los hijos no es buena idea. La Vanguardia. Retrieved from http://www.lavanguardia.com/vida/20180205/44554866125/uso-moviltecnologias-adolescentes-hijos.html

Euskal Irrati Telebista (eitb) - Radio Televisión Vasca

- González, R. (Producer). (2018, February 16). El Programa de Klaudio [Television broadcast]. Bilbao, Spain: ETB2. Retrieved from: https://www.eitb.tv/es/video/el-programa-de-klaudio/5795/144496/16-022018/

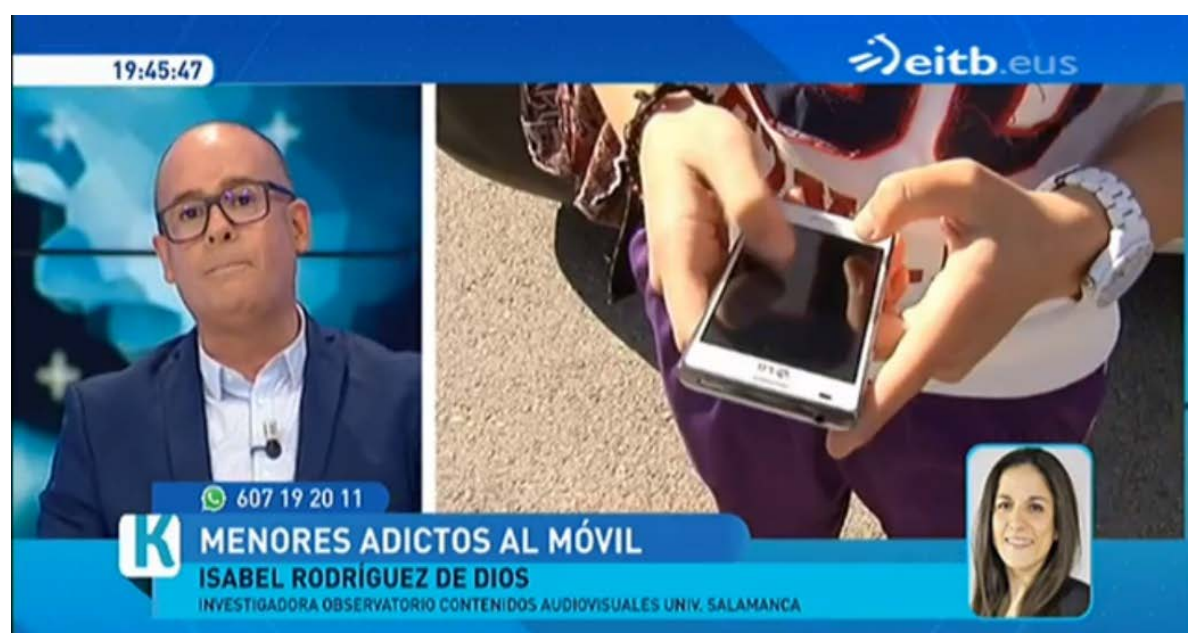




\section{Tendencias}

El dificll equilibrio entre educacion y relaciones famillares

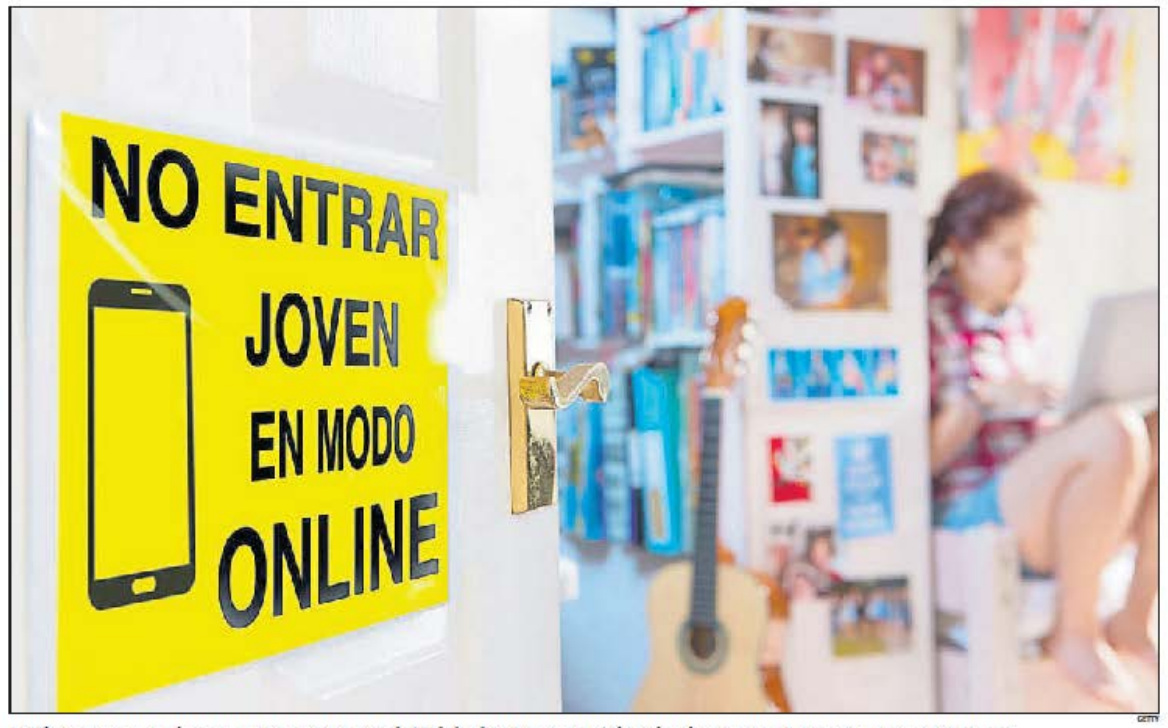

Los jóvenes que pasan más tlempo

\section{Restringir el móvil a los hijos no es buena idea}

Limitar a los adolescentes el uso de las tecnologías reduce riesgos pero les resta oportunidades
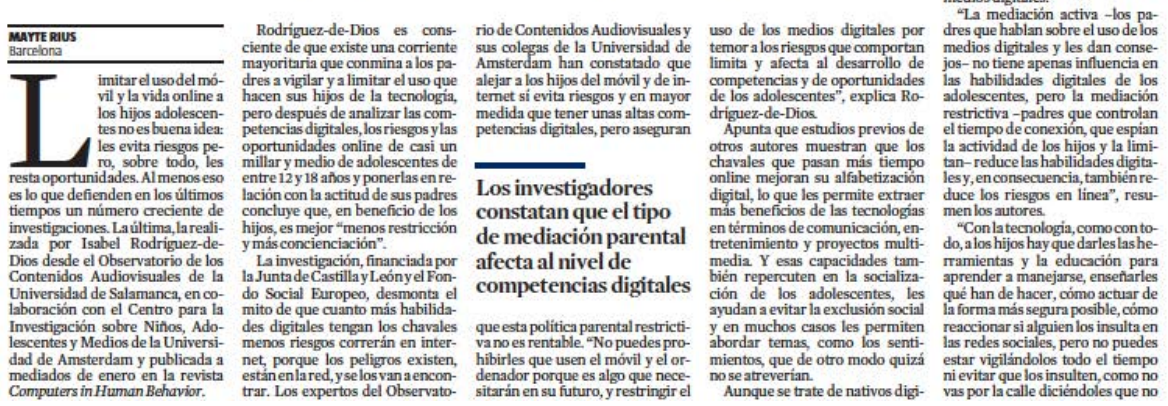
LUNES, 5 FEBRERO 2018

TEN DEN CI A S

LAVANGUARDIA 23

UN CONSUMO MUY
EXIENDIDO ENTRE

\begin{tabular}{|c|c|c|c|}
\hline $\begin{array}{l}\text { Con } 12 \text { affos } \\
\text { El } 96 \% \text { de los menores } \\
\text { usa el ordenador y se } \\
\text { conecta a intemet, yel } \\
\text { 75\% tlene movill }\end{array}$ & $\begin{array}{l}\text { Con } 15 \text { años } \\
\text { El } 94 \% \text { de los chicos y chicas } \\
\text { de era edad dispone de movil, } \\
\text { yel } 99 \% \text { usa internet }\end{array}$ & 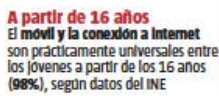 & 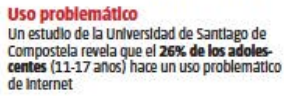 \\
\hline
\end{tabular}

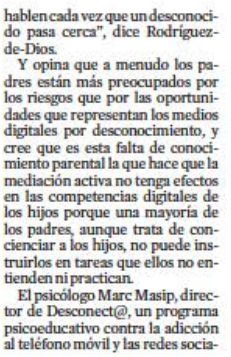

Masip, experto en adicciones, prioriza los riesgos y pide que se rrabajen las habilidades por otros medios

les, coincide enlanecesidad de ha-
cer un trabajo de concienciacio sobre el buen uso de las tecrologias, pero no commarte que el us

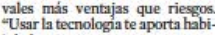
lidades, pero ninguna que no pue

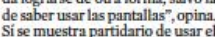
Si se muestra partidario de usar el
ordenadorenel ambito académico
para appender a realizar una navepación inteligente, por internet,
buscar información sobre aquello que se necesite y a encontrar fuen-
tes de calidad, pero considera que resto de habilidades -comun etcétera-esmejor trabajajlas vis tando, compartiendo, leyendo
escribiendo "por métodos reales, no en el móvil uotras pantallas".
Masip se muestra radicalmente encontra de que los menores de 1 que regalándoles pantallas a loo
hijos les restamos habilidad para

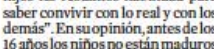
16 ahosos los niniosnoestinmmaduros
para usar dispositivos tecnológpara usar dispositivos tecrnolog.
cos con tanto potencial, "y los padres se los damos comoun privile. gio que creemos que se merecen
con la excusid de que todos lo tie con ha excus de que todos lo tie
nen, pero las consecuencias son horrorosas e e implicican un peor
rendimiento académico, peor forma de relacionarse, peor autwestima ", enfatiza este experto en adicciones digitales Ydice que,
el caso de los hijos mayores de 16 el caso de los hijos mayores de
antos, los padres deben establece

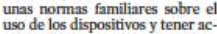
uso de los dispositivos y tener a san y qué les interessa a sus hijos. Con todo, diversass investigaciorestriccionoses de los padrese en e de los medios digitales apuntan riesgioy sia sumentan los conffictos
familiares (véase información de

Las claves de la alfabetización digital -Los investigadores de la Universidad de Salamanca Isabel Ro

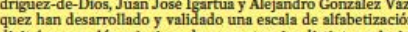
digital que evalúa seis tipos de competencias distintas relacio-

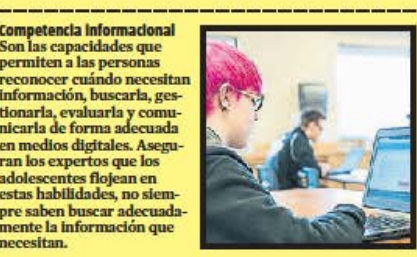

Competencla tecnologlica o Instrumental cona para utillizar el ordenador o el móvil, para instalar protienen los adolescentes analizados por los investigadores,
dado que son nativos difitiales y manejan con facilidad todo dado que son nativos

Competencta en seguritad personal

capacidad de la persona para salvaguardar su privacidad online y proteger suidentidad enque los adolescentes sacan notas más bajas, y no porquen
sepan cómo conffigurar los dispositivos ola privacidad de sus redes sociales, sino porque
no son conscientes delas consecuencias des alyunas de sus acciones, como mostrar
fotosen las que pueda identifotos en las sue pueda ident-
ficarse dónde viven o osturrampara que las imaigenes svea sólo la red privad

Competencla comunicatte

Anailza la capacidad que tiene el usuario de comunicarse a
través de las herramientas digitales En el caso de los adolescentes, los investigadores concluyen que presentan un nivel sobre todo, practicando.

Competencla en segurldad de disposittives
Mide la capacidad para tomar precauc

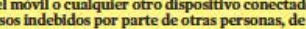
Infecciones de virus o de programas espin. En este ímbito,
los datos del estudio liderado por Rodriguez-de-Dios indican que los adolescentes están adoptan muy pocas precar ciones para minimizar los
riesgos de ser victimas de
los cilberdelincuentes. ompetencia se puede fomentar a través de h form

Competencta crnica
Es la capacidad de analizar con espiritu critico la información obtenida, de juzgar si es verazo falsa, si la fuente o si lo Segin Rod centes estín bastante perdidos, $y$ es peligroso que se crean toda la informaclón que encuentran sobre todo en ámbitos desarrollar esa capacidad critica para juzzar la veracidad de
Las reglas sobre el uso de las pantallas ocasionan conflictos intergeneracionales y hacen aflorar disparidades de los padres

\section{Una casa dividida}

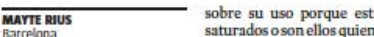

saturados oson ellos quiene

$\mathrm{E}=$ tam- logia sea negociado, primero
entre los padres, que debe genitores, porque a la hora aclarar por qué dejan ono
de fijar limites, realizar ad- móvilal hijo, si es para que vertencias o facilitar activi- relacione con la tecnologia con otros niños o es por des de criterio, de enfoque padres.
Psicologos, pedagogos y do, se negocia con el hijo
encue el acuerdo debe ser ran quela gestión del móvily no actúa en bloque y hay tres la negociación se va lógicos se ha convertdo en de las manos", dice Pinilla
uno de los principales moti-
Pero esta unidad de critevos de confficto que llevana rio parental no resulta fíciexperiencia en los casos de "En el uso del móvil esta uso abusivo del móvil es que tatus y los roles sobre la que dela tecnologia, es frecuente se construye la convivencia que cada progenitor dige
pacifica en cada familia", una cosa, porque no percidice Laura González, media- ben el problema de la mism dora y formandora en el IIns- manera y eso provocas mu-
tituto Complutense de Me- chas discusiones en la parej tituto Complutense de Me- chas discusiones en la pare-
diación y Gestión de Con- y tensiones familiares. flictos (Imedia-UCM) y co- A este respecto, Pinilla ex-

Losmediadores dicen que parejasque seden el uso del móvil se ponen del móvil de los eluso del $\begin{array}{ll}\text { a prueba el rol familiar y } & \text { suele ser motive } \\ \text { de fricciono * En }\end{array}$ \begin{tabular}{ll} 
una convivencia pacífica & $\begin{array}{l}\text { el plan de paren- } \\
\text { talidad, igual que }\end{array}$ \\
\hline
\end{tabular} laboradora de Isep Clinic hijos o qué extraescolin lose Madrid de harin, se abordac cómo van Mediación Barcelona, cree procesos de mediación de--
que el problema no es la tec- tectamos que a menudo los nologia, porque los con- padres se sienten avergonnologia, porque los con- padres se sienten avergon-
flictos intergeneracionales zados oculpables porque sacon los adolescentes siem- ben que un uso excesivo es
pre han existido - thace cua- malo pero loconsienten porpre han existido-"hace cua- malo pero loconsienten por-
renta años eran por salir a la
que están superados y sien-

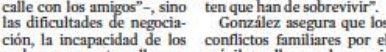
ción, la incapacidad de los confictos familiares por
padres para pactar y llegar a movil que llegan a los servi-
mats acuerdos. Y asegura que esa cios de mediación son mu-
dificultad se deriva de una chos menos de los reales $\begin{array}{ll}\text { falta de educación emocio-- } & \text { porque los padres y madre } \\ \text { nal y y menudo de un cierto } & \text { suelen resistirse a reconooer }\end{array}$ sentimiento de culpa en los que el hijo hace un uso quienes han dado el móvil al eso deteriora su propi
hijo para que no moleste o
immagen parental, como edu 